UNIVERSIDADE DE SÃO PAULO

INSTITUTO DE GEOCIÊNCIAS

\title{
O GRUPO CARRANCAS E A FRENTE DA NAPPE ANDRELÂNDIA NA BORDA SUL DO CRÁTON DO SÃO FRANCISCO: PROVENIÊNCIA SEDIMENTAR E IMPLICAÇÕES TECTÔNICAS
}

\author{
Alice Westin Teixeira \\ Orientador: Prof. Dr. Mario da Costa Campos Neto \\ DISSERTAÇÃO DE MESTRADO \\ Programa de Pós-Graduação em Mineralogia e Petrologia
}

SÃO PAULO 
Autorizo a reprodução e divulgação total ou parcial deste trabalho por qualquer meio convencional ou eletrônico para fins de estudo e pesquisa, desde que citada a fonte.

Westin, A. O Grupo Carrancas e a frente da Nappe Andrelândia na borda sul do cráton do São Francisco: proveniência sedimentar e implicações tectônicas. 2011. 154p. Dissertação (Mestrado em Geociências) - Instituto de Geociências, Universidade de São Paulo, São Paulo. 
"Uma pergunta de quando eu era pequena e que só agora me respondo: as pedras são feitas ou nascem? Resposta: as pedras estão" Clarice Lispector 
A toda minha família.

Ao Rafa. 


\section{AGRADECIMENTOS}

Primeiramente, agradeço a toda a minha família (mãe, pai, Cris, vó, tias, tios, primos, primas e sobrinhos-primos..ufa!). Vocês todos têm participação em tudo que eu decido e realizo na minha vida. Ao Rafa, meu amor e companheiro pra todas as horas. Obrigada pelas risadas, pelas conversas inúteis e por todo o carinho, sempre.

Ao Pavão pelas coordenadas UTM, pela base do mapa geológico e por sempre estar disposto a ajudar. Muito obrigada.

À Bis, por tudo. Pelas caronas, pela parceria no pilates, pelas cervejas de nomes impronunciáveis, pela ajuda com o mapa, resumo e abstract, por aturar minhas perguntas sem sentido. Enfim, por tudo mesmo.

À Lua, parceira! Obrigada por sempre estar disposta a ajudar. Obrigada pela ajuda com o resumo e abstract e pelos chocolatinhos que sempre me animam!

Ao Harry, por me ensinar nesses anos de convivência a ser muito mais paciente. Obrigada pelo carinho e preocupação e por se animar comigo quando eu descubro coisas que são incrivelmente legais....por 5 minutos.

Às minhas irmãs Carol, Joaninha (agora com a Luiza!), Grazi, Junia e Lua (de novo!), por me animarem, sempre.

Aos meus amigos, irmãos, camaradas de turma que não me abandonaram neste barco: Popó, Bruna, GG, Meninão, Pânico, Rejeitto e Xang. Ao Kabong pelas risadas, por ouvir meus desabafos e por me dar muitos abraços.

Ao CEPEGE, que mais uma vez provou seu dom de fazer com que os problemas se tornem pequenininhoss....pequenininhossss...

Ao Mário por me orientar neste trabalho. Por respirar fundo e contar até 10 de vez em quando e por me ensinar e orientar sempre. Suas observações e puxões de orelha foram imprescindíveis para evolução deste trabalho.

Agradeço também às pessoas que com certeza tornaram a minha vida e a confecção da dissertação muito mais fáceis: Aninha e Magali por sempre salvarem a pátria em momentos de desespero; Zé Paulo pelo auxilio na preparação das amostras; Sandra e Paulinho pelos dados de geoquímica de rocha; Vasco e Mauricio pela grandissíssíssíma ajuda na separação dos zircões (por duas vezes, inexistentes); ao pessoal da biblioteca pela simpatia e ajuda; ao pessoal da gráfica por tornarem o momento mais desesperador da dissertação muito mais tranquilo.

Por fim, agradeço à FAPESP pelo apoio financeiro que tornou possível a realização deste trabalho. 


\section{RESUMO}

O Sistema de Nappes Carrancas compõe um sistema de nappes que circunda ao sul o Cráton do São Francisco e é formado pela Unidade Biotita Xisto e pelas formações Campestre e São Tomé das Letras do Grupo Carrancas. A Unidade Biotita Xisto contém veios de quartzo e xistosidade anastomosada e é formada por quartzo, biotita, muscovita, clorita e, localmente plagioclásio, carbonato e granada. A Formação Campestre é formada por quartzitos intercalados a filitos/xistos que variam de cloritóide filitos grafitosos, com muscovita, quartzo e turmalina e, localmente, granada a xistos com granada, estaurolita e cianita.

A investigação da Unidade Biotita Xisto como autóctone em relação ao Cráton do São Francisco, seu potencial agrupamento com o Grupo Carrancas em uma megassequência deposicional, bem como sua comparação com a unidade alóctone Xisto Santo Antônio (Nappe Andrelândia) constituem parte dos objetivos deste estudo. Para tal, foram feitas análises químicas e isotópicas ( $\mathrm{Sr}$ e $\mathrm{Nd}$ ) em rocha total e geocronologia $\mathrm{U}-\mathrm{Pb}$ em cristais de zircão detríticos, tanto na Unidade Biotita Xisto como na Formação Campestre, com intuito de elucidar a relação entre as mesmas e compará-las com dados da literatura disponíveis para o Xisto Santo Antônio.

A Unidade Biotita Xisto apresenta características químicas compatíveis com sedimentos que sofreram intemperismo químico de intensidade e período de tempo moderados, depositados em ambientes de colisão continental, com área-fonte composta essencialmente por rochas félsicas. Assinaturas de elementos traço e isotópicas de $\mathrm{Sr}\left({ }^{87} \mathrm{Sr} /{ }^{86} \mathrm{Sr}\right.$ entre 0,713 e 0,715$)$ e $\mathrm{Nd}$ $\left(\varepsilon_{\mathrm{Nd}}\right.$ entre -6 e -5) indicam contribuição de arco magmático e crosta continental e diferem, portanto, daquelas esperadas em ambientes de margem passiva. A mesma contribuição é observada para o Xisto Santo Antônio, cuja área fonte registra importante assinatura de material juvenil. As idades U-Pb LA-MC-ICP MS obtidas em cristais de zircão mostram contribuição principal de rochas do final do Criogeniano e contribuição secundária do Riaciano. A classe modal ao redor de 665 Ma é comparável com a idade cristais de zircão detrítico do Xisto Santo Antônio, o que aponta para uma mesma área-fonte principal para ambas unidades. A deposição dos sedimentos precursores da Unidade Biotita Xisto ocorreu entre 630-611 Ma, sendo as fontes principais os granulitos cálcio-alcalinos e rochas vulcânicas co-genéticas, além de granitos sin-colisionais da Nappe Socorro-Guaxupé. A pouca representatividade de idades paleoproterozóicas e a ausência de assinaturas químicas de margem passiva, inviabilizam as rochas do Cráton do São Francisco como parte da área-fonte. 
Desta forma, a Unidade Biotita Xisto não é autóctone em relação ao Cráton do São Francisco, sendo, potencialmente, a unidade que compõe a frente da Nappe Andrelândia.

Por outro lado, a Formação Campestre possui assinatura geoquímica de sedimentos que sofreram uma intensa reciclagem e alteração da composição do sedimento original. As assinaturas químicas de elementos traço e isotópicas $\mathrm{Sr}$ e $\mathrm{Nd}$ indicam contribuição de crosta continental superior, com componente de crosta antiga e sem afinidade com sedimentos depositados em margem passiva $\left({ }^{87} \mathrm{Sr} /{ }^{86} \mathrm{Sr}\right.$ entre 0,74 e 0,$76 ; \varepsilon_{\mathrm{Nd}}$ entre -18 e -15$)$. Os zircões detríticos analisados forneceram idades U-Pb LA-MC-ICP-MS variadas, do Toniano ao Mesoarqueano, correlacionáveis com rochas vulcânicas e plutônicas do Cráton do São Francisco, com as faixas marginais do Cráton de Angola e/ou faixas orogênicas do Cráton Amazônico e com rochas dos arcos Mara Rosa e Goiás. A abrangência das idades U-Pb da Formação Campestre e das formações Chapada dos Pilões e Paracatu, permite a correlação, no Orógeno Brasília, entre os Grupos Carrancas e Canastra. A paleogeografia mais provável é a de um ambiente de rifte, antecessor à deriva e ao estabelecimento de uma margem continental passiva.

Palavras-chave: proveniência sedimentar; ambiente deposicional; geoquímica elemental e isotópica; geocronologia $\mathrm{U}-\mathrm{Pb}$. 


\begin{abstract}
The Carrancas Nappe System composes a system of nappes that surround the southern margin of the São Francisco Craton and is formed by the Biotite Schist Unit and by the Campestre and São Tomé das Letras formations of the Carrancas Group. The Biotite Schist Unit encompass quartz veins and anastomosed schistosity and is formed by quartz, biotite, muscovite, chlorite and, locally plagioclase, carbonate and garnet. The Campestre Formation is composed by interleaved quartzites and phyllite/schist that varies from graphite-chloritoid phyllites, with muscovite, quartz, tourmaline and garnet, and locally garnet schists and schists with garnet, staurolite and kyanite.

The investigation of the Biotite Schist Unit as authochtonous in relation to the São Francisco Craton, it's potencial grouping with the Carrancas Group in a deposicional megassequence, as well as it's comparison with the allochthonous Santo Antônio Schist (Andrelândia Nappe) is part of the goals of this study. For this purpose, chemical and isotopic ( $\mathrm{Sr}$ and $\mathrm{Nd}$ ) whole rock analysis were obtained, along with U-Pb detrital zircon data, in the Biotite Schist Unit and also in the Campestre Formation, in order to elucidate the relationship between these units and compare them with literature data available for the Santo Antônio Schist.

The Biotite Schist Unit show chemical characteristics compatible with sediments that underwent chemical weathering of moderate intensity and time, deposited in continental collision setting, with source region composed essentially by felsic rocks. Trace elements and Sr isotopic signatures $\left({ }^{87} \mathrm{Sr} /{ }^{86} \mathrm{Sr}\right.$ between 0,713 and 0,715$)$ and $\mathrm{Nd}\left(\varepsilon_{\mathrm{Nd}}\right.$ between -6 and -5$)$ points to contribution from magmatic arc and continental crust, and are different from the expected for passive margin settings. The same contribution is observed in the Santo Antônio Schist, which source area registers an important juvenile material signature. The U-Pb LAMC-ICP MS zircon data show major contribution from rocks of the later Cryogenian and minor contribution from the Ryacian. The modal class around $655 \mathrm{Ma}$ is comparable with the $\mathrm{U}-\mathrm{Pb}$ detrital zircon data from the Santo Antônio Schist, pointing to the same source area for both units. The deposition of the precursors sediment of the Biotite Schist Unit occurred between 630 - $611 \mathrm{Ma}$, and the main sources were the calk-alcaline granulites and co-genetic volcanic rocks, besides the Socorro-Guaxupé Nappe sin-collisional granites. The low representation of Paleoproterozoic ages and the absence of passive margin chemical signatures preclude the rocks of the São Francisco Craton as part of the source area. Thus, Biotite Schist Unit is not an autochthonous unit in relation to the São Francisco Craton,
\end{abstract}


and is, potentially, the unit that composes the Andrelândia Nappe front.

On the other hand, the Campestre Formation has geochemical signatures of sediments that underwent intense recycling and alteration of the original sediment. The trace element and $\mathrm{Sr}$ and $\mathrm{Nd}$ isotopic signatures indicates upper continental crust contribution, with older crust component and no affinity with passive margin sediments $\left({ }^{87} \mathrm{Sr} /{ }^{86} \mathrm{Sr}\right.$ between 0,74 and 0,76 ; $\varepsilon_{\mathrm{Nd}}$ between -18 and -15). The U-Pb LA-MC-ICP MS detrital zircon data provide varied ages, from the Tonian to the Mesoarchean, correlated with volcanic and plutonic rocks of the São Francisco Craton, with the marginal belts of the Angola Craton, and/or orogenic belts of the Amazonian Craton and with the Mara Rosa and Goiás magmatic arcs. The range of the U-Pb ages of the Campestre Formation and the Chapada dos Pilões and Paracatu formations, allows the correlation, in the Brasília Orogen, of the Campestre and Canastra groups. The most likely paleogeography is that of a rift setting, before the continental drift and the establishment of a passive continental margin.

Keywords: provenance analysis; tectonic setting; chemical and isotopic whole rock analysis; $\mathrm{U}-\mathrm{Pb}$ detrital zircon data. 


\section{SUMÁRIO}

Capítulo I - INTRODUÇÃ̃o..............................................................................................1

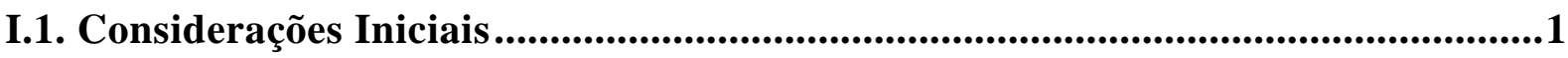

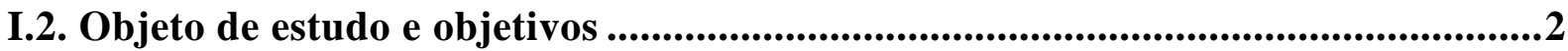

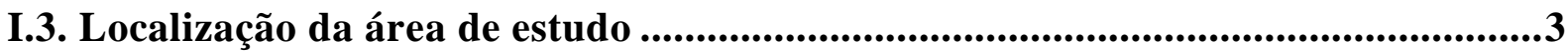

Capítulo II - MATERIAis E Métodos ..........................................................................4

II.1. Levantamentos Bibliográficos ..............................................................................4

II.2. Trabalho de campo ...............................................................................................4

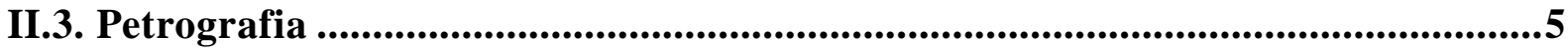

II.4. Geoquímica Elemental...........................................................................................6

II.4.1. Análise de elementos maiores, menores e traços por FRX ....................................... 7

II.4.2. Análise de elementos terras raras por ICP-MS ......................................................

II.5. Geoquímica Isotópica ...........................................................................................8

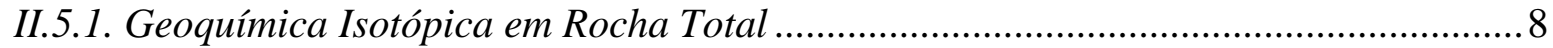

II.5.1.1. Sistema isotópico Rb-Sr em rocha total ........................................................... 9

II.5.1.2. Sistema isotópico Sm-Nd em rocha total ............................................................ 13

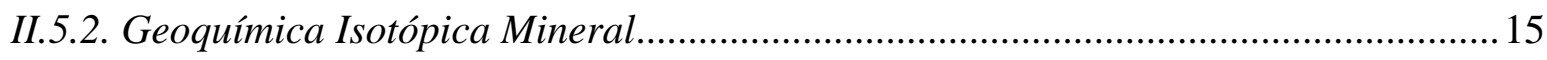

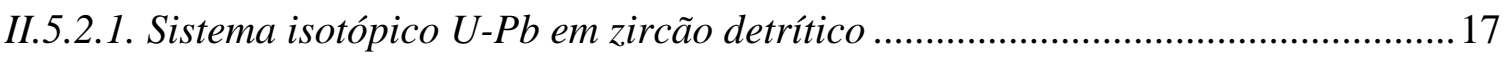

II.6. Elaboração da dissertação ...................................................................................22

Capítulo III - Proveniência Sedimentar.........................................................23

III.1. Proveniência Sedimentar - Aplicações.................................................................25

III.2. Proveniência sedimentar - Métodos de determinação .....................................25

III.2.1. Análise mineralógica petrográfica de minerais detríticos .......................................26

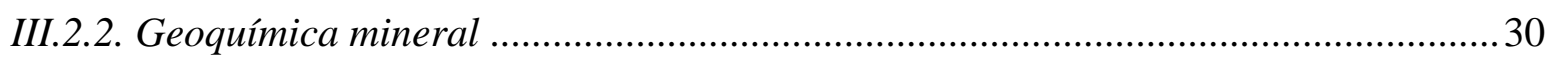

III.2.3. Geoquímica de rochas sedimentares .................................................................. 35

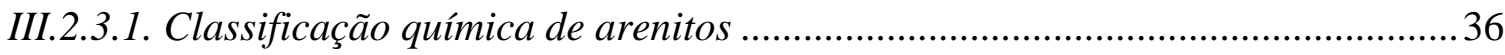

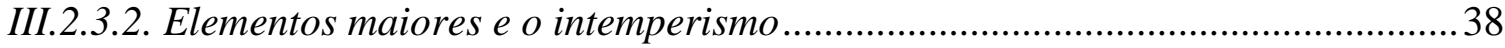

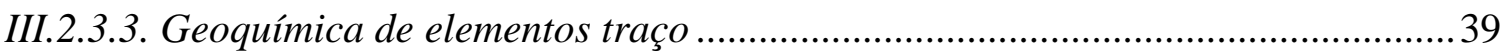

Capítulo IV - Contexto Geológico Regional ....................................................46 


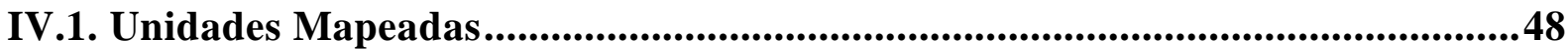

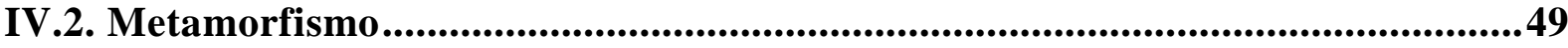

IV.3. Análise Estrutural ......................................................................................51

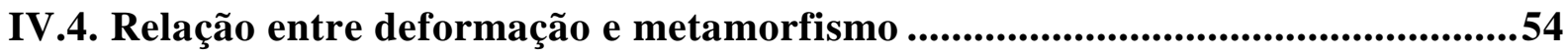

IV. 5. Geocronologia ..........................................................................................55

IV.6. Paleoambiente deposicional ..................................................................56

Capítulo V - Litotipos Amostrados ............................................................................58

V.1. Unidade Biotita Xisto (UBX) - Pranchas de fotos I, II, III e IV ........................59

V.2. Formação Campestre (FC) - Pranchas de fotos I, V, VI e VII ..........................61

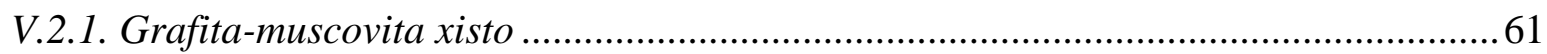

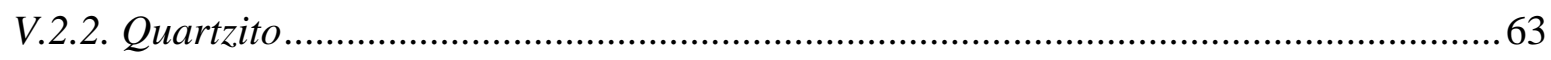

V.3. Formação São Tomé das Letras - Prancha de fotos VIII ..............................63

Capítulo VI - GeoQuímica Elemental ........................................................65

VI.1. Elementos maiores e menores ................................................................66

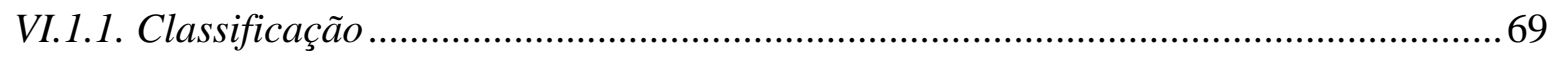

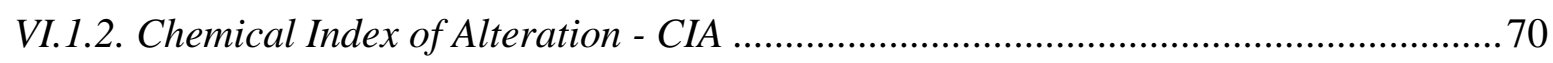

VI.2. Geoquímica de elementos traços ..........................................................................71

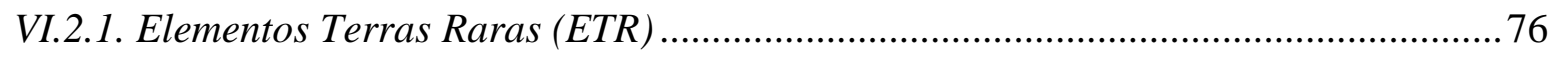

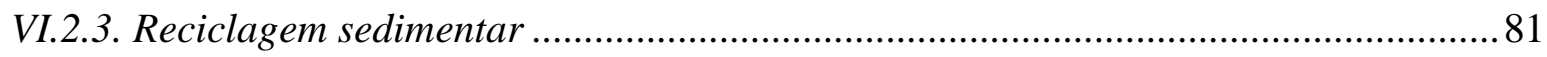

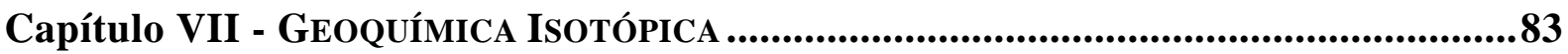

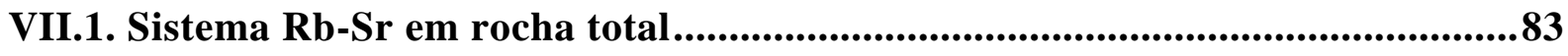

VII.2. Sm-Nd em rocha total ...................................................................................84

Capítulo VIII - GeOcronologia U - PB ..........................................................87

Capítulo IX - Ambiente Deposicional e Área-Fonte Principal ........................94

IX.1. Ambiente de deposição ....................................................................................94

IX.2. Área-Fonte principal .............................................................................96

Capítulo X - Comparações entre a Unidade Biotita Xisto E A Formação

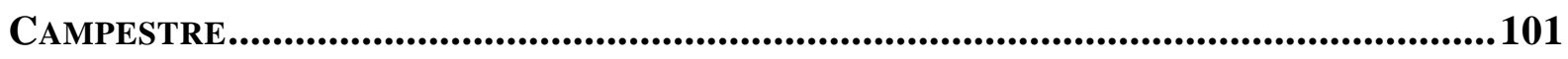


X.1. Geoquímica de elementos maiores e menores

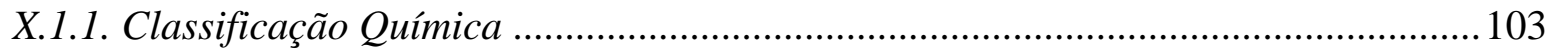

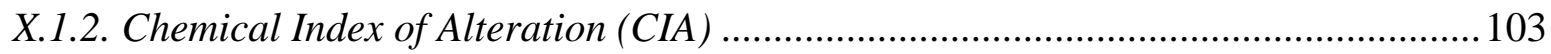

X.2. Geoquímica de elementos traços ..........................................................105

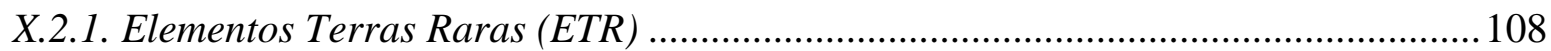

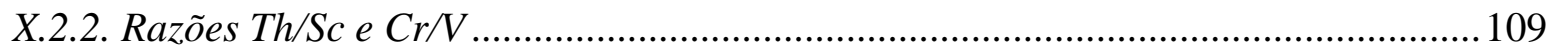

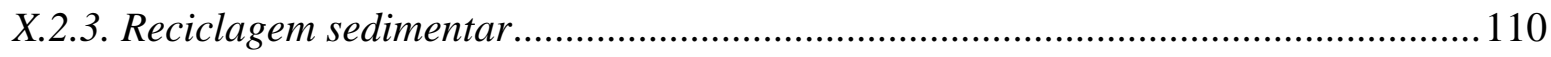

X.3. Assinatura isotópica ....................................................................................112

X.4. U-Pb em cristais de zircão detrítico .........................................................115

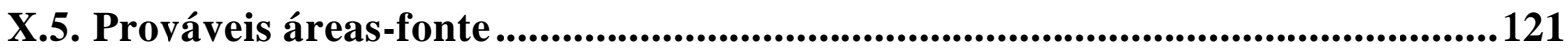

Capítulo XI - Comparações entre as Unidades Biotita Xisto E Xisto Santo

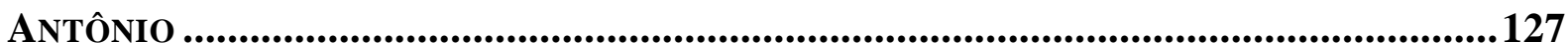

XI.1. Elementos maiores e menores .......................................................................127

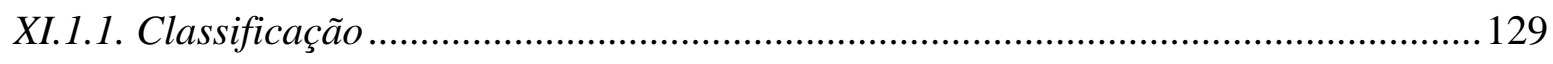

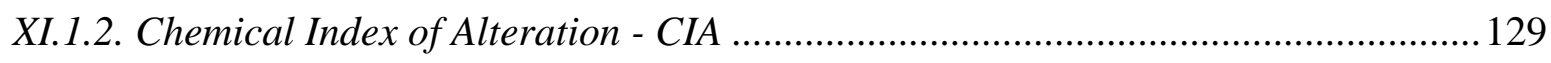

XI.2. Geoquímica de elementos traços ...................................................................... 131

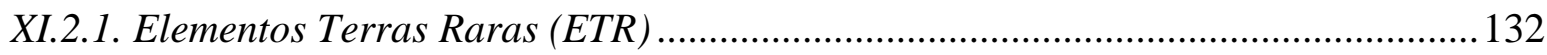

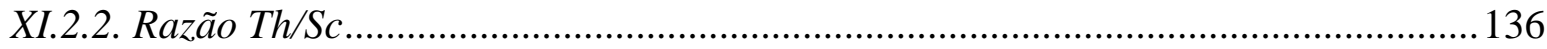

XI.3. Sistema Rb-Sr em rocha total .......................................................................137

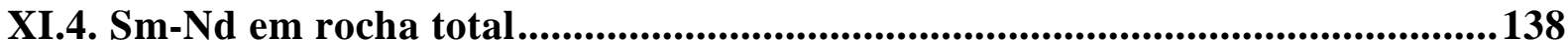

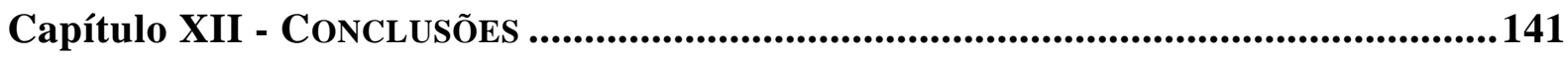

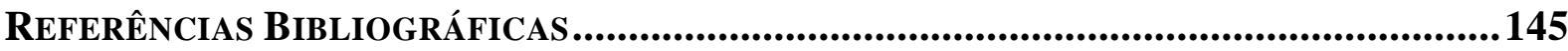




\section{Índice de Figuras}

\section{Capítulo I - Introdução}

Figura I.1: Localização e acesso à área de estudo

\section{Capítulo II - Materiais e Métodos}

Figura II.1: Diagrama isocrônico do sistema Rb-Sr extraído de White (2009).

Figura II.2: Gráfico $\varepsilon_{\mathrm{Nd}} v s .{ }^{87} \mathrm{Sr} /{ }^{86} \mathrm{Sr}$ com a delimitação dos campos de rochas de origem mantélica e de origem crustal.

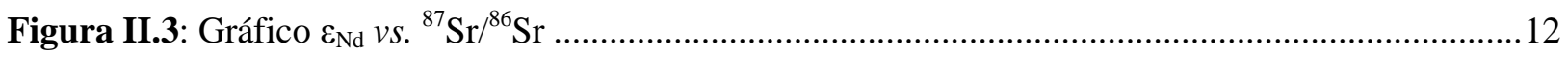

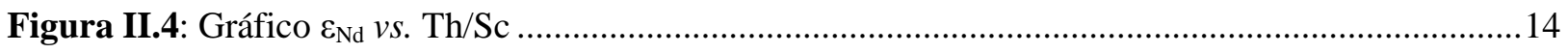

Figura II.5: Parte da tabela de nuclídeos que mostra os elementos intermediários que participam das reações de decaimento de ${ }^{238} \mathrm{U},{ }^{235} \mathrm{U}$ e ${ }^{232} \mathrm{Th}$ para ${ }^{206} \mathrm{~Pb},{ }^{207} \mathrm{~Pb}$ e ${ }^{208} \mathrm{~Pb}$. .................................................. 19

Figura II.6: Diagrama ${ }^{206} \mathrm{~Pb} /{ }^{238} \mathrm{U}$ vs. ${ }^{207} \mathrm{~Pb} /{ }^{235} \mathrm{U}$ com concórdia calibrada em Ma. .................................20

Figura II.7: Histograma de distribuição de probabilidade e densidade de idades U-Pb .........................21

\section{Capítulo III - Proveniência Sedimentar}

Figura III.1: Esquema em bloco de um ambiente de sedimentação com os principais mecanismos que controlam a assembléia mineral de uma rocha sedimentar

Figura III.2: Características ópticas observáveis em microscópio petrográfico de três inossilicatos pertencentes ao Grupo dos Piroxênios .

Figura III.3: Características ópticas observáveis em microscópio petrográfico de três nesossilicatos,

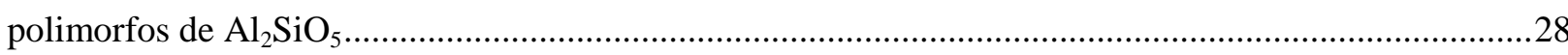

Figura III.4: Texturas de dissolução em minerais estáveis e moderadamente estáveis.

Figura III.5: Diagrama de classificação dos minerais pertencentes ao grupo dos piroxênios de rochas ígneas de diferentes ambientes tectônicos

Figura III.6: Diagrama de classificação de minerais do grupo do piroxênio a partir de suas concentrações de óxidos de $\mathrm{Si}$, Ti, $\mathrm{Al}, \mathrm{Fe}, \mathrm{Mn}, \mathrm{Mg}$, $\mathrm{Ca}$ e $\mathrm{Na}$

Figura III.7: Diagrama de $\mathrm{Nb}$ ppm vs. Cr ppm com os campos de composição de rutilo de rochas máficas, rochas metacumuláticas e rochas metapelíticas

Figura III.8: Gráficos de concentração Y (ppm) vs. U (ppm) e Ce/Ce* vs. Eu/Eu* para zircões de origem ígnea de diferentes litotipos

Figura III.9: Gráfico $\mathrm{SiO}_{2} / \mathrm{Al}_{2} \mathrm{O}_{3}$ vs. $\mathrm{Na}_{2} \mathrm{O} / \mathrm{K}_{2} \mathrm{O}$ de classificação de arenitos............................................

Figura III.10: Gráfico $\mathrm{SiO}_{2} / \mathrm{Al}_{2} \mathrm{O}_{3}$ vs. $\mathrm{Fe}_{2} \mathrm{O}_{3} / \mathrm{K}_{2} \mathrm{O}$ de classificação de arenitos .....................................38

Figura III.11: Diagramas ternários da fração molar de A-CN-K.............................................................40 


\section{Capítulo IV - Contexto Geológico Regional}

Figura IV.1: Mapa geológico regional com ênfase na Megassequência Andrelândia..

Figura IV.2: Mapa Tectônico do Orógeno Brasília Meridional.............................................................48

Figura IV.3: Mapa estrutural da zona de interferência das Faixas Brasilia e Ribeira.....

\section{Capítulo V - Litotipos Amostrados}

Figura V.1: Fotos de afloramentos da Unidade Biotita Xisto e das formações Campestre e São Tomé das Letras

\section{Capítulo VI - Geoquímica Elemental}

Figura VI.1: Gráficos binários de dispersão de $\mathrm{SiO}_{2} v s$. elementos maiores e menores analisados por FRX.

Figura VI.2: Amostras da UBX plotadas no diagrama de classificação química de arenitos segundo Pettijohn et al. (1972).

Figura VI.3: Amostras da UBX plotadas no diagrama de classificação química de arenitos segundo Herron (1988). .70

Figura VI.4: Amostras analisadas plotadas no diagrama ternário da fração molar de A-CN-K .72

Figura VI.5: Diagrama spider de elementos traços para as amostras da UBX. . .73

Figura VI.6: Diagramas de $\mathrm{Al}_{2} \mathrm{O}_{3}$ vs. $\mathrm{Rb}$, Cs e $\mathrm{Ba}$ para as amostras da UBX. .75

Figura VI.7: Diagramas Harker de Zr e Hf 75

Figura VI.8: Padrão de Elementos Terras Raras das amostras da UBX analisadas. .............................. 77

Figura VI.9: Gráfico de fracionamento de ETRP vs. Anomalia de Eu para a UBX ................................78

Figura VI.10: Diagramas Th/Sc vs. CIA, Eu/Eu* vs. CIA e Eu/Eu* vs. Cr/V para a UBX ...................80

Figura VI.11: Gráfico Zr/Sc vs. Th/Sc para a UBX.

\section{Capítulo VII - Geoquímica Isotópica}

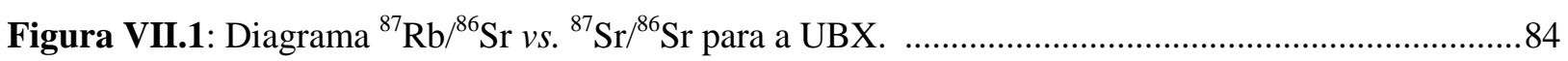

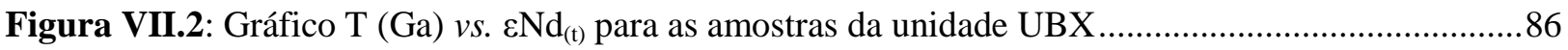

\section{Capítulo VIII - Geocronologia U-Pb}

Figura VIII.1: Cristais de zircão detrítico da UBX separados para análise do sistema U-Pb ..................88

Figura VIII.2: Imagens back-scattered dos cristais de zircão detrítico analisados. ...............................89

Figura VIII.16: Diagramas concórdia ${ }^{207} \mathrm{~Pb} /{ }^{238} \mathrm{U} v$ s. ${ }^{206} \mathrm{~Pb} /{ }^{238} \mathrm{U}$ e idades ${ }^{207} \mathrm{~Pb} /{ }^{206} \mathrm{~Pb}$ obtidas em cristais de zircão detrítico da UBX. 


\section{Capítulo IX - Ambientes Deposicional e Área-Fonte principal}

Figura IX.1: Classificação química segundo o ambiente tectônico de deposição.

Figura IX.2: Ilustração comparativa dos intervalos de idades obtidas em zircões detríticos da UBX com os intervalos de idade de granulitos, charnokitos, migmatitos, gnaisses, granitos, mangeritos, monzogranitos e sienitos da Nappe Socorro-Guaxupé.

Figura IX.2: Diagramas. ${ }^{87} \mathrm{Sr} /{ }^{86} \mathrm{Sr} v s$. $\varepsilon \mathrm{Nd}$ e $\mathrm{Th} / \mathrm{Sc} v s$. $\varepsilon \mathrm{Nd}$ para as amostras da UBX, com os campos dos granulitos da Nappe Socorro-Guaxupé.

\section{Capítulo X - Compararações entre a Unidade Biotita Xisto e a Formação Campestre}

Figura X.1: Diagramas Harker para as amostras da FC.

Figura X.2: Amostras da unidade UBX e da FC plotadas no diagrama de classificação química de arenitos segundo Herron (1988). 104

Figura X.3: Amostras analisadas plotadas no diagrama ternário da fração molar A-CN-K 105

Figura X.4: Diagrama spider das concentrações de elementos traço da FC e da UBX. 108

Figura X.5: Padrão de Elementos Terras Raras das amostras da FC em comparação com as amostras da UBX.

Figura X.6: Gráfico de fracionamento de ETRP vs. Anomalia de Eu da FC.

Figura X.7: Diagrama CIA vs. Th/Sc, CIA vs. Eu/Eu* e Eu/Eu* vs. Cr/V para a FC e para a UBX. .....110

Figura X.8: Gráfico Zr/Sc vs. Th/Sc para a FC e para a UBX .............................................................111

Figura X.9:Gráfico T (Ga) vs. $\varepsilon \mathrm{Nd}_{(\mathrm{t})}$ para FC.

Figura X.10: Diagramas de classificação química segundo o ambiente tectônico de deposição para a FC.

Figura X.11: Cristais de zircão detrítico da FC separados para análise do sistema U-Pb.

Figura X.12: Imagens back-scattered dos cristais detríticos da FC analisados.

Figura X.13: Diagrama concórdia ${ }^{207} \mathrm{~Pb} /{ }^{238} \mathrm{U} v s .{ }^{206} \mathrm{~Pb} /{ }^{238} \mathrm{U}$ e distribuição de probabilidade do quartzito da Formação Campestre.

Figura X.14: Idades obtidas nos cristais de zircão detrítico da amostra CAR-II-179 e as idades das possíveis rochas-fonte para os sedimentos da Formação Campestre.

\section{Capítulo XI - Comparações entre a Unidade Biotita Xisto e o Xisto Santo Antônio}

Figura XI.1: Gráficos binários de dispersão de $\mathrm{SiO}_{2}$ vs. elementos maiores e menores analisados por FRX para as amostras do XSA e da UBX.

Figura XI.2: Amostras do XSA e da unidade UBX plotadas no diagrama de classificação química de arenitos segundo Pettijohn et al. (1972).

Figura XI.3: Amostras do XSA da unidade UBX plotadas no diagrama de classificação química de arenitos segundo Herron (1988). 
Figura XI.4: Amostras do XSA e da unidade UBX plotadas no diagrama ternário da fração molar A$\mathrm{CN}-\mathrm{K}$

Figura XI.5: Diagrama spider de elementos traços para as amostras do XSA e da UBX.

Figura XI.6: Diagramas de $\mathrm{Al}_{2} \mathrm{O}_{3} v s$. Ba, $\mathrm{Rb}$ e Cs para as amostras do XSA e da UBX.

Figura XI.7: Padrão de Elementos Terras Raras das amostras do XSA.

Figura XI.8: Gráfico de fracionamento de ETRP vs. Anomalia de Eu com as amostras do XSA e da UBX.

Figura XI.9: Diagramas CIA vs. Th/Sc, CIA vs. Eu/Eu* e Th/Sc vs. Cr/V para as amostras do XSA e da UBX.

Figura XI.10:Gráfico $\mathrm{T}(\mathrm{Ga})$ vs. $\varepsilon \mathrm{Nd}_{\mathrm{T}}$ para as amostras do XSA e da UBX.

Figura XI.11: Amostras do XSA e da UBX plotadas em diagramas de classificação química segundo o ambiente tectônico de deposição.

\section{Índice de tabelas}

\section{Capítulo II - Materiais e Métodos}

Tabela II.1: amostras analisadas petrograficamente.

Tabela II.2: amostras analisadas quimicamente para obtenção de elementos maiores, menores, traço e Elementos Terras Raras.

Tabela II.3: amostras analisadas para obtenção dos sistemas Rb-Sr e Sm-Nd. ....................................9

Tabela II.4: amostras analisadas para obtenção do sistema U-Pb em cristais de zircão detrítico.

Tabela II.5: meia-vida $\left(t_{1 / 2}\right)$ e constante de decaimento das reações que produzem os três elementos radioativos de $\mathrm{Pb}$ presentes na natureza.

\section{Capítulo III - Proveniência Sedimentar}

Tabela III.1: classificação de estabilidade dos principais minerais pesados utilizados em estudos de proveniência

Tabela III.2: principais líquidos densos utilizados na separação de minerais detríticos.........................27

Tabela III.3: razões minerais aplicadas em estudos de HMA convencional. .......................................29

Tabela III.4: assinaturas de elementos traço de zircões metamórficos e ígneos ......................................34

Tabela III.5: concentrações de Hf e Y em zircões de rochas ígneas formadas a partir de processos

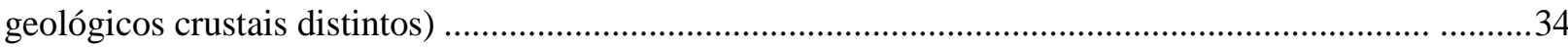

Tabela III.6: razão $\mathrm{Zr} / \mathrm{Hf}$ em rochas ígneas de diferentes ambientes tectônicos ....................................35

Tabela III.7: composição de elementos maiores da crosta continental superior.....................................40 
Tabela III.8: composição de alguns elementos traço da crosta continental superior...

Tabela III.9: concentração de elementos traço de várias médias composicionais de sedimentos clásticos

\section{Capítulo IV - Contexto Geológico Regional}

Tabela IV.10: principais paragêneses metamórficas dos grupos Carrancas e São João del Rei.... .52

Tabela IV.11: paleoambientes possíveis para unidades da Megassequência Andrelândia $56 /$ 57

\section{Capítulo VI - Geoquímica Elemental}

Tabela VI.1: simbologia das amostras e a divisão adotada segundo a localização geográfica em relação às serras das Bicas e do Pombeiro e a estrutura regional.

Tabela VI.2: resultados obtidos para elementos maiores e menores por FRX para a UBX.

Tabela VI.3: valores de CIA para as amostras analisadas.

Tabela VI.3: análises de elementos traço obtidas por FRX a UBX.

Tabela VI.4: análises de elementos traço obtidas por LA-ICP MS para a unidade UBX.

Tabela VI.5: valores da razão $\mathrm{Th} / \mathrm{Sc}, \mathrm{Cr} / \mathrm{V}$ e $\mathrm{Eu}_{\mathrm{N}} \mathrm{Eu}^{*}$ para as amostras da UBX

Tabela VI.6: valores das razões $\mathrm{La} / \mathrm{Sc}, \mathrm{Th} / \mathrm{Sc}$ e $\mathrm{Zr} / \mathrm{Sc}$ para as amostras da UBX e valores de referência para crosta continental superior, média e inferior extraídos da literatura.

\section{Capítulo VII - Geoquímica Isotópica}

Tabela VII.1: dados isotópicos e elementais do sistema Rb-Sr para a UBX.

Tabela VII.2: dados isotópicos e elementais do sistema Sm-Nd para UBX.

Tabela VII.3: $\varepsilon \mathrm{Nd}_{\mathrm{TDM}}$ e recalculados para $590 \mathrm{Ma}$ e 610 Ma para UBX.

\section{Capítulo VIII - Geocronologia U-Pb}

Tabela VIII.1: razões ${ }^{207} \mathrm{~Pb} /{ }^{235} \mathrm{U},{ }^{206} \mathrm{~Pb} /{ }^{238} \mathrm{U},{ }^{207} \mathrm{~Pb}{ }^{206} \mathrm{~Pb}$, seus respectivos erros $(1 \sigma)$ e os valores de rho da UBX.

Tabela VIII.2: idades ${ }^{207} \mathrm{~Pb} /{ }^{235} \mathrm{U},{ }^{206} \mathrm{~Pb} /{ }^{238} \mathrm{U},{ }^{207} \mathrm{~Pb}^{1206} \mathrm{~Pb}$, seus respectivos erros e os valores de concordância da UBX.

\section{Capítulo IX - Ambiente Deposicional e Área-Fonte principal}

Tabela IX.1: idades ${ }^{207} \mathrm{~Pb} /{ }^{206} \mathrm{~Pb}$ em monazita e zircão para granulitos, charnokitos e granitos da Nappe Socorro-Guaxupé. 


\section{Capítulo X - Compararações entre a Unidade Biotita Xisto e a Formação Campestre}

Tabela X.1: resultados obtidos para elementos maiores e menores por análises de FRX para amostras da FC

Tabela X.2: valores de CIA para as amostras da FC 104

Tabela X.3: razões e concentrações de elementos traço obtidas pelo método de FRX a FC. 106

Tabela X.4: elementos traço obtidas pelo método de ICP-MS para a FC 107

Tabela X.3: valores das razões $\mathrm{La} / \mathrm{Sc}, \mathrm{Th} / \mathrm{Sc}$ e $\mathrm{Zr} / \mathrm{Sc}$ para a FC.

Tabela X.7: dados isotópicos e elementais do sistema $\mathrm{Rb}-\mathrm{Sr}$ para a FC.

Tabela X.8: dados isotópicos e elementais do sistema Sm-Nd para a FC.

Tabela X.10: razões ${ }^{207} \mathrm{~Pb} /{ }^{235} \mathrm{U},{ }^{206} \mathrm{~Pb} /{ }^{238} \mathrm{U},{ }^{207} \mathrm{~Pb}^{1206} \mathrm{~Pb}$, seus respectivos erros $(1 \sigma)$ e os valores de rho da FC

$117 / 118$

Tabela X.11: idades ${ }^{207} \mathrm{~Pb} /{ }^{235} \mathrm{U},{ }^{206} \mathrm{~Pb} /{ }^{238} \mathrm{U},{ }^{207} \mathrm{~Pb}{ }^{1206} \mathrm{~Pb}$, seus respectivos erros e os valores de concordância da amostra C-431 da FC

$119 / 120$

\section{Capítulo XI - Comparações entre a Unidade Biotita Xisto e o Xisto Santo Antônio}

Tabela XI.1: Síntese dos resultados obtidos para elementos maiores e menores por análises de FRX

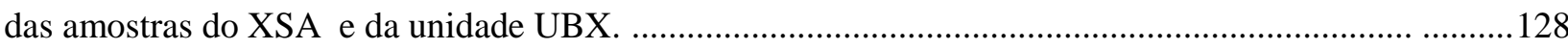

Tabela XI.2: valores de CIA para as amostras do XSA e da unidade UBX. ........................................130

Tabela XI.3: valores de elementos traço obtidos através de análise em LA-ICP MS para as amostras do XSA

Tabela XI.4: valores de elementos terras raras (ETR) para as amostras do XSA.

Tabela XI.5: valores da razão $\mathrm{Th} / \mathrm{Sc}$ para as amostras do XSA e da unidade UBX.

Tabela XI.6: dados isotópicos e elementais do sistema Rb-Sr para as amostras do XSA e da unidade UBX

Tabela XI.7: dados isotópicos e elementais do sistema Sm-Nd para as amostras do XSA e da unidade UBX. 


\section{Capítulo I}

\section{INTRODUÇÃO}

\section{I.1. Considerações Iniciais}

A crosta continental, com espessura média de aproximadamente $40 \mathrm{~km}$ (Rudnick e Gao, 2003), abrange apenas 0,35\% da massa da Terra (Taylor e McLennan, 1995), sendo formada por litologias variadas que contêm grandes proporções de elementos traços (Taylor e McLennan, 1995; Rudnick e Gao, 2003).

A reincorporação da crosta continental superior ao manto é incomum e o estudo da composição química deste importante reservatório geoquímico é uma forte ferramenta para a determinação de modelos da composição global da Terra (Taylor e McLennan, 1995). Além disso, determinar se a composição química global da crosta continental superior se modificou, ou não, ao longo da evolução geológica da Terra é de extrema importância para entender se os processos de formação da crosta e de diferenciações geoquímicas, que influenciam os mecanismos de evolução do planeta, sofreram modificações temporais (Taylor e McLennan, 1985; Rudnick e Gao, 2003).

As rochas sedimentares têm sido formadas por processos relativamente contínuos de erosão da crosta continental e sedimentação há pelo menos 4,0 bilhões de anos (McLennan, 2001). Os estudos geoquímicos destas rochas auxiliam nas estimativas da composição da crosta continental superior, pois registram grande parte da evolução geoquímica da crosta ao longo da formação do planeta. (McLennan, 2001).

Alterações químicas associadas ao intemperismo, erosão, transporte sedimentar, deposição, diagênese e metamorfismo são comuns durante a formação de rochas sedimentares e interferem na composição final destas rochas. Entretanto, elementos traço como Th e Sc e Terras Raras são insolúveis na água do mar (Bhatia e Crook, 1986) e transportados para sedimentos terrígenos. A distribuição destes elementos, nas rochas sedimentares, pode, então, refletir a composição da área-fonte (McLennan et al., 1990; McLennan e Taylor, 1991). Outros elementos como zircônio ( $\mathrm{Zr}$ ), háfnio (Hf), nióbio $(\mathrm{Nb})$ e estanho ( $\mathrm{Sn}$ ) têm comportamento semelhante aos citados anteriormente, porém suas concentrações estão condicionadas ao fracionamento mineral durante transporte e deposição do sedimento, pois 
tendem a se concentrar em minerais pesados, como zircão, monazita e apatita (McLennan et al., 1990; McLennan e Taylor, 1991).

A comparação entre a composição das rochas sedimentares e a composição da crosta continental superior deveria ser feita, em principio, a partir das análises e dos cálculos de médias composicionais de todas as rochas sedimentares aflorantes na superfície terrestre (McLennan e Taylor, 1991). Entretanto, os sedimentos terrígenos de granulação fina (argilitos e siltitos) compreendem cerca de $70 \%$ da massa sedimentar (Garrels e Mackenzie, 1971) e são enriquecidos em elementos traços (ETR, Th e Sc) quando comparados a outras rochas sedimentares (como a maioria dos arenitos, carbonatos e evaporitos). Assim, as análises das composições químicas destas rochas seriam suficientes para estimar a composição da crosta terrestre, pois elas controlariam completamente o balanço de massa destes elementos (McLennan e Taylor, 1991).

O estudos destes elementos traço e suas variáveis (como razões e anomalias negativas e positivas) aliados à geoquímica isotópica de rocha total (como sistema $\mathrm{Sm}-\mathrm{Nd}$ ) e mineral (U-Pb em zircão detrítico) formam um grupos de análises consistentes para a determinação de proveniência de rochas sedimentares e metassedimentares e, consequentemente, para o estabelecimento do ambiente de deposição e do contexto tectônico vigentes durante o processo de sedimentação (Taylor e McLennan, 1985).

\section{I.2. Objeto de estudo e objetivos}

O objeto de estudo desta monografia é a Unidade Biotita Xisto, homogênea e de cor acinzentada, descrita pela primeira vez por Trouw et al. (1980), como sendo uma rocha composta por quartzo, biotita, muscovita, clorita e, localmente plagioclásio, carbonato e granada e, caracteristicamente, com vênulas de quartzo.

O estudo destas rochas tem como objetivo principal avaliar se estas são autóctones em relação ao Cráton do São Francisco (Trouw et al., 2000), com base no ambiente tectônico e idade da área-fonte, bem como das condições gerais de deposição. São comparadas com a unidade alóctone, Xisto Santo Antônio, da Nappe Andrelândia, estas oriundas de ambiente exótico ao cráton (Campos Neto et al., 2011) e procura discutir o agrupamento destas unidades e do Grupo Carrancas como uma megassequência deposicional (Ribeiro et al., 1995; Pacciullo et al., 2002).

Para cumprir tal objetivo, as seguintes etapas foram executadas: 
(i) Identificar sua proveniência, ambiente tectônico durante a sedimentação e idade máxima da deposição através de análises químicas de rocha total (elemental e isotópica) e pontuais em zircão (sistema isotópico $\mathrm{U}-\mathrm{Pb}$ ).

(ii) Comparar as feições observadas em campo e os dados obtidos nas análises químicas e isotópicas com as características do Xisto Santo Antônio (Trouw et al. 1983; Campos Neto et al., 2007) da Nappe Andrelândia e com as rochas das unidades do Grupo Carrancas (Heilbron 1984 e 1985; Ribeiro e Heilbron, 1982; Trouw et al, 1983; Valeriano et al., 2004; Valladares et al., 2008).

\section{I.3. Localização da área de estudo}

A área objeto deste estudo localiza-se a norte da cidade de Carrancas, no sudeste de Minas Gerais. Trata-se de um polígono de, aproximadamente, $32 \mathrm{~km}$ x $14 \mathrm{~km}$ de área, que compreende parte das serras do Pombeiro, da Estância, de Carrancas e das Bicas (figura I.1B).

A principal via de acesso se dá pela rodovia BR-381 (Rodovia Fernão Dias) até a cidade de Lavras, onde se encontra o acesso à rodovia BR-265, Passando a cidade de Itumirim, há uma saída para as cidades de Itutinga e Carrancas que, consequentemente, acessa a área estudada (figura I.1A).

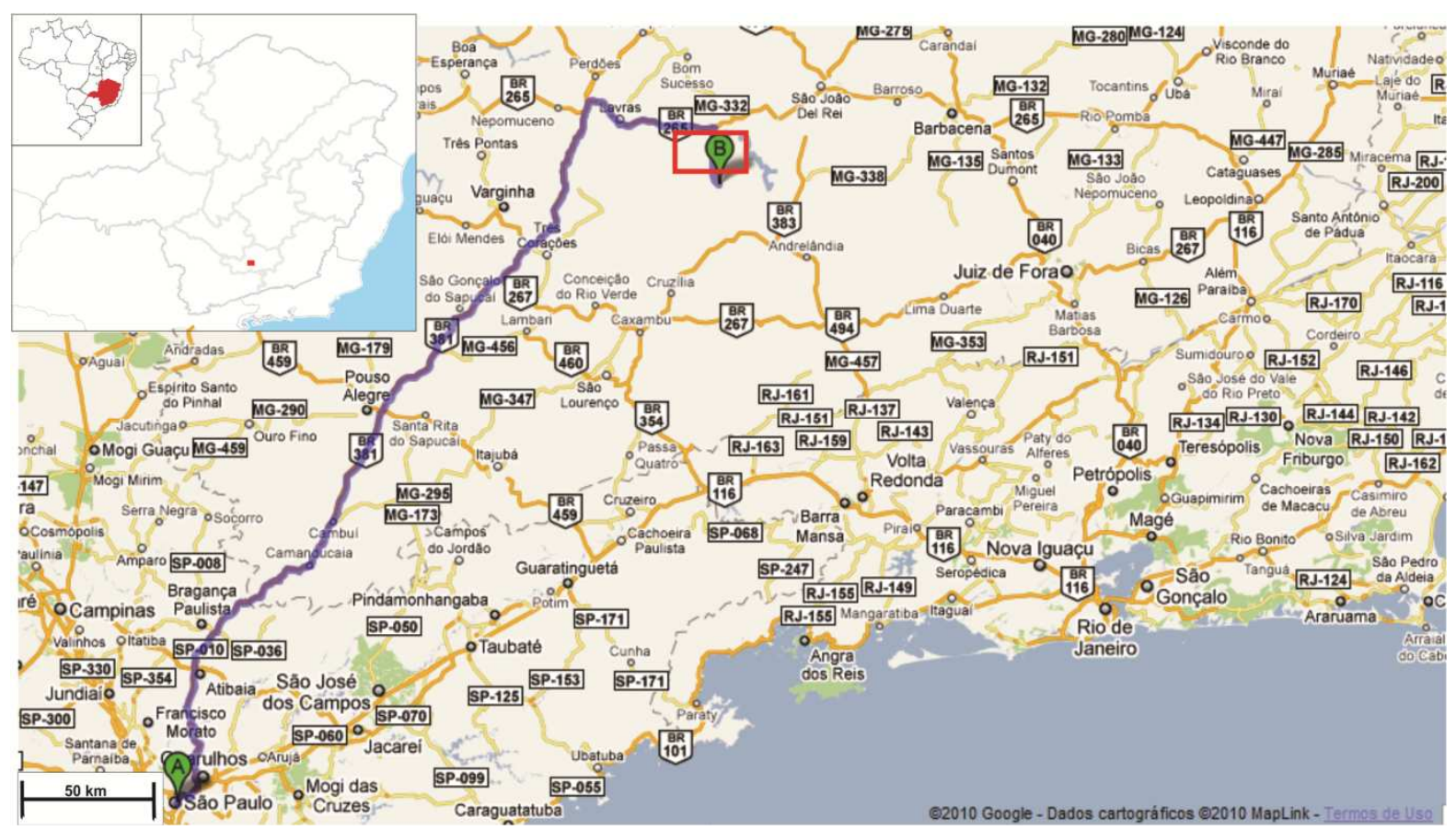

Figura I.1: Localização e acesso à área de estudo (retângulo vermelho na figura I.1 B). Na figura I.1A, o balão verde com a letra A corresponde à cidade de São Paulo e o balão com a letra B corresponde à cidade de Carrancas. 


\section{Capítulo II}

\section{MATERIAIS E MÉTODOS}

\section{II.1. Levantamentos Bibliográficos}

A revisão bibliográfica foi feita através da consulta de artigos publicados em revistas científicas, trabalhos apresentados em congressos e simpósios, livros texto, relatórios de mapeamento geológico, além de trabalhos acadêmicos como monografias de trabalho de formatura, dissertações de mestrado e teses de doutorado.

Todo o material consultado foi adquirido na biblioteca do Instituto de Geociências da Universidade de São Paulo (IGc - USP) e no portal Periódicos CAPES.

\section{II.2. Trabalho de campo}

As atividades de campo foram realizadas no início e fim do ano de 2009 com o orientador Prof. Dr. Mario da Costa Campos Neto, e o geólogo Leandro Coutinho, mestrando do IGc - USP.

A primeira etapa foi direcionada para a região nordeste da cidade de Carrancas e a leste das serras de Carrancas e das Bicas (folha Itutinga - SF-23-X-C-I-4). A segunda etapa concentrou-se na área a noroeste da cidade de Carrancas, na região da Serra do Pombeiro (folha Itutinga e folha Itumirim - SF-23-X-C-I-3).

Seções contínuas ao longo destas áreas foram executadas com o intuito de identificar as unidades geológicas, suas características estruturais de campo (foliações, faixas de cisalhamento, fases de deformação) e as relações de contato, quando observáveis, entre a Unidade Biotita Xisto e as demais Unidades do Grupo Carrancas (Trouw et al., 1980). Foi realizada a amostragem sistemática para os estudos petrográficos, químicos, isotópicos e geocronológicos. 


\section{II.3. Petrografia}

As amostras utilizadas para as descrições petrográficas foram coletadas durante os trabalhos de campo da disciplina 0440420 - Mapeamento Geológico do IGc - USP durante os anos de 2008 e 2009 e durante as etapas de campo deste trabalho (tabela II.1).

Estas amostras foram serradas em serra circular e enviadas para a Seção de Laminação do IGc - USP para a confecção de seções delgadas de $30 \mu \mathrm{m}$ de espessura.

Depois de prontas, as seções foram descritas em um microscópio petrográfico Olympus, modelo BXP - 50, no Laboratório de Microscopia Petrográfica do IGc - USP com ênfase na mineralogia, texturas e microestruturas deformacionais, bem como as reações metamórficas entre os minerais e a relação destas com as fases de deformação observadas nesta escala.

\begin{tabular}{|c|c|c|c|}
\hline & \multicolumn{2}{|c|}{ Mapeamento Geológico IGc - USP } & \multirow{2}{*}{$\begin{array}{l}\text { Etapas de campo deste } \\
\text { trabalho }\end{array}$} \\
\hline & 2008 & 2009 & \\
\hline Unidade Biotita Xisto & $\begin{array}{c}\text { CAR-I-51; CAR-IV-06; } \\
\text { CAR-IV-06a; } \\
\text { CAR-IV-06ba; } \\
\text { CAR-IV-42; } \\
\text { CAR-V-116; } \\
\text { CAR-IX-129 }\end{array}$ & CM-III-25 & $\begin{array}{c}C-300 ; C-309 b ; C-325 b ; \\
C-328 a ; C-329 a ; C-330 a ; \\
C-330 b ; C-331 b ; C-333 b ; \\
C-335 ; C-336 ; C-337 ; C-340 \\
C-341 b ; C-345 b ; C-359 ; C 410 ; \\
C-410 a ; C-411 ; C-430 ; C-431\end{array}$ \\
\hline $\begin{array}{l}\text { Formação Campestre } \\
\text { (Trouw et al., 1980) }\end{array}$ & $\begin{array}{c}\text { CAR-I-32; CAR-III-76; } \\
\text { CAR-II-108; CAR-IV- } \\
\text { 52B; CAR-IV-129; } \\
\text { CAR-IV-152; CAR-V- } \\
\text { 17; CAR-IX-11;CAR- } \\
\text { II-179 }\end{array}$ & - & $\begin{array}{c}\text { C-301b; C-308a; C-317; C-318; } \\
\text { C-344; C-371; C-375; C-379; } \\
\text { C-381a; C-381b; C-397; C-400; } \\
\text { C-412; C-421;C-421b; C-426 }\end{array}$ \\
\hline $\begin{array}{c}\text { Formação São Tomé } \\
\text { das Letras (Trouw et } \\
\text { al., 1980) }\end{array}$ & - & - & $\begin{array}{c}C-305 ; C-398 ; C-399 a ; C-399 c \\
C-401 ; C-401 a ; C-417\end{array}$ \\
\hline
\end{tabular}

Tabela II.1: amostras analisadas petrograficamente. 


\section{II.4. Geoquímica Elemental}

Para a obtenção de elementos maiores, menores, traços e elementos terras raras (ETR) foram analisadas 13 (treze) amostras daquelas coletadas nos trabalhos de campo mencionados no item II.1, sendo 11 (onze) amostras da Unidade Biotita Xisto e 2 (duas) do Xisto Grafitoso da Formação Campestre (tabela II.2).

As amostras foram analisadas em três etapas: (i) lote 1: amostras CAR-I-31, CAR-I-52 e CAR-II-76; (ii) lote 2: C-325c, C-333, C-337, C-340, C-341 e CM-III-25; e (iii) lote 3: amostras C-410, C-411, C-430 e C-431,

A preparação das amostras para análise laboratorial foi efetuada no Laboratório de Tratamento de Amostras (LTA) do IGc - USP, com a orientação do técnico responsável MSc. José Paulo Sertek e consistiu em:

(i) limpeza das amostras que foram lavadas e serradas para extração das porções alteradas;

(ii) Cominuição em prensa hidráulica para obter fragmentos menores que $1 \mathrm{~cm}$ e para a retirada de possíveis porções alteradas remanescentes da primeira etapa;

(iii) Quarteamento para retirada de aproximadamente 100g representativos da amostra;

(iv) Moagem em moinho de ágata do tipo planetário até obtenção de pó com tamanho de grão inferior a 200 mesh;

\begin{tabular}{|c|c|c|c|}
\hline & \multicolumn{2}{|c|}{ Mapeamento Geológico } & \multirow{2}{*}{$\begin{array}{c}\text { Etapas de campo } \\
\text { deste trabalho }\end{array}$} \\
\hline & 2008 & 2009 & \\
\hline Unidade Biotita Xisto & $C A R-I-51$ & $C M-I I I-25$ & $\begin{array}{c}C-325 b ; C-333 ; \\
C-337 ; C-340 ; \\
C-341 ; C-410 ; \\
C-411 ; C-430 ; \\
C-431\end{array}$ \\
\hline $\begin{array}{c}\text { Formação Campestre - } \\
\text { Xisto Grafitoso }\end{array}$ & CAR-I-32; CAR-II-76 & - & - \\
\hline
\end{tabular}

Tabela II.2: amostras analisadas quimicamente para obtenção de elementos maiores, menores, traço e Elementos Terras Raras. 


\section{II.4.1. Análise de elementos maiores, menores e traços por Fluorescência de Raio-X (FRX):}

Os elementos maiores, menores e alguns traços foram analisados a partir de pastilhas fundidas e prensadas no laboratório de Espectometria de Fluorescência de Raio-X (FRX) do IGc - USP pelo físico e técnico especializado responsável Paulo Ernesto Mori (tabelas VI.2 e VI.3). Utilizou-se o equipamento automático Philips, modelo PW2400 e a metodologia empregada foi a descrita em Mori et al.(1999).

As pastilhas prensadas foram confeccionadas no LTA. Após a moagem, cerca de 7,0 g de cada amostra foram micronizados e levados para secagem na estufa. Após esta etapa, as amostras foram homogeneizadas manualmente com $20 \%$ de ligante em pó e depois levadas para prensa hidráulica. As pastilhas fundidas foram produzidas no laboratório de Laboratório de Química e ICP-AES/MS do IGc - USP pelo técnico especializado Paulo Ernesto Mori.

Os materiais de referência geoquímica internacional utilizados para o teste de exatidão foram o basalto JB-1a, nos lotes 1 e 3 e o granodiorito JG-1a no lote 2, Os valores obtidos para os óxidos apresentaram exatidão ideal, sendo que a diferença entre os valores recomendados e obtidos não ultrapassou os $5 \%$ em todas as etapas. Os valores obtidos para os elementos menores e traços também foram satisfatórios e no geral a diferenças entre valores recomendados e obtidos não ultrapassou os $10 \%$ em todas as etapas, com exceção dos elementos $\mathrm{Ce}, \mathrm{La}, \mathrm{Nd}, \mathrm{Pb}$, Th e V nos lotes 1 e 3 e $\mathrm{Cr}, \mathrm{Nb}, \mathrm{Ni}, \mathrm{Pb}$, Th, $\mathrm{U}$ e $\mathrm{V}$ no lote 2, que apresentaram diferenças de até $56 \%$.

Análise de duplicata foi feita apenas no segundo lote para a $4^{\mathrm{a}}$ (quarta) amostra analisada. A diferença entre as análises não ultrapassou os 5\% para os óxidos e os $10 \%$ para os elementos menores e traço, com exceção dos elementos Nd, Sc, U e Y que chegaram a ultrapassar os $30 \%$.

\section{II.4.2. Análise de elementos terras raras por espectometria de massa com plasma induzido acoplado (ICP-MS)}

Para obtenção de elementos traços e ETR, as 13 (treze) amostras citadas no item II.4 foram analisadas no Laboratório de Química e ICP-AES/MS do IGc - USP, pela química e 
técnica especializada MSc Sandra Andrade, utilizando critérios descritos em Navarro (2004). O laboratório utiliza um espectrômetro do tipo quadrupolo, modelo ELAN 6100DRC da PerkinElmer/Sciex para obtenção de elementos traço e terras raras.

Os materiais de referência utilizados para o teste de exatidão foram o granito JG-3 e o riolito JR-1 nos 3 (três) lotes. Os valores obtidos (tabela VI.4) foram coerentes, sendo que a diferença entre os resultados obtidos e recomendados para a maioria dos elementos ficou abaixo de $10 \%$. Valores acima disso ocorreram para ambos os padrões, sendo que o elemento Ho se destacou dos demais por apresentar altos valores em todos os lotes (padrão JG-3: entre 38 e 43\%; padrão JR-1: entre 15 e 17\%).

Análise de duplicata foi executada para a última análise feita em cada um dos 3 (três) lotes. Com exceção da amostra CM-III-25 do segundo lote, que apresentou diferenças entre 11 e $27 \%$ para a maioria dos elementos, as duplicatas deram valores com diferenças abaixo de $10 \%$ em relação aos resultados obtidos na primeira análise.

\section{II.5. Geoquímica Isotópica}

Análises de geoquímica isotópica podem fornecer, além de idades, informações sobre as condições de formação da rocha estudada, sejam em rocha total ou em mineral.

A utilização de diversos sistemas isotópicos de maneira combinada é uma importante ferramenta para a identificação e caracterização da área fonte que gerou sedimentos e metassedimentos. Neste caso, é possível identificar o tipo de rocha que atuou como fonte, se esta tem origem mantélica, crustal ou é produto de reciclagem sedimentar, permitindo uma identificação geral do ambiente de deposição e do contexto geotectônico da época da sedimentação.

\section{II.5.1. Geoquímica Isotópica em Rocha Total}

Para análises de geoquímica isotópica em rocha total foram escolhidos os sistemas Rubídio-Estrôncio (Rb-Sr) e Samário-Neodímio ( $\mathrm{Sm}-\mathrm{Nd})$. Estes sistemas, além de amplamente utilizados e descritos na literatura, são os que oferecem melhores resultados no que diz respeito à identificação de proveniência sedimentar. Idades modelo (Sm-Nd), idades de episódios de formação ( $\mathrm{Rb}-\mathrm{Sr}$ ), e caracterização de fonte, são algumas das informações que podem ser extraídas no tratamento de dados provenientes de análises destes sistemas em rochas sedimentares e metassedimentares. Para isto, foram analisadas 11 (onze) amostras 
daquelas coletadas nos trabalhos de campo mencionados no item II.1, sendo 08 (oito) amostras da Unidade Biotita Xisto e 3 (três) do Xisto Grafitoso da Formação Campestre) (tabela II.3).

A preparação das amostras foi efetuada no LTA do IGc - USP, com a orientação do técnico responsável MSc. José Paulo Sertek e seguindo os quatro passos descritos no item II.4, Após esta etapa, as amostras foram enviadas ao Centro de Pesquisas Geocronológicas onde foram encaminhadas para os laboratórios de $\mathrm{Rb}-\mathrm{Sr}$ e de $\mathrm{Sm}-\mathrm{Nd}$.

\begin{tabular}{lcc|c}
\hline & \multicolumn{2}{c}{ Mapeamento Geológico } & $\begin{array}{c}\text { Etapas de campo } \\
\text { deste trabalho }\end{array}$ \\
\cline { 2 - 4 } & $\mathbf{2 0 0 8}$ & $\mathbf{2 0 0 9}$ & \\
\hline Unidade Biotita Xisto & CAR-I-51; & & $C-325 b ; C-333 ;$ \\
& $C A R-I X-129$ & $C M-I I I-25$ & $C-337 ; C-340 ;$ \\
\hline $\begin{array}{c}\text { Formação Campestre - } \\
\text { Xisto Grafitoso }\end{array}$ & CAR-I-32; CAR-II-76; & & $C-341$ \\
\hline
\end{tabular}

Tabela II.3: amostras analisadas para obtenção dos sistemas Rb-Sr e Sm-Nd.

\section{II.5.1.1. Sistema isotópico $\mathrm{Rb}$-Sr em rocha total}

$\mathrm{Na}$ natureza são encontrados dois isótopos naturais do elemento químico $\mathrm{Rb}$, sendo estes o ${ }^{85} \mathrm{Rb}\left(72,17 \%\right.$ de abundância relativa) $\mathrm{e}^{87} \mathrm{Rb}(27,83 \%$ de abundância relativa).

O isótopo ${ }^{87} \mathrm{Rb}$ é radioativo e decai para o elemento radiogênico ${ }^{87} \mathrm{Sr}$ segundo a seguinte equação:

$$
{ }_{37}^{87} \mathrm{Rb} \rightarrow{ }^{87}{ }_{38} \mathrm{Sr}+\boldsymbol{\beta}^{-}+\mathrm{v}+\mathbf{Q}
$$

Onde $\beta$ é a partícula radioativa emitida durante o decaimento e $Q$ é a energia liberada durante a reação. O decaimento ocorre segundo uma taxa constante, entretanto, no caso do sistema Rb-Sr, a baixa energia de decaimento - $275 \mathrm{keV}$ - dificulta a determinação da constante, sendo que valores distintos, porém semelhantes, são encontrados na literatura (Dickin, 1995a): 
- Neumann \& Huster (1976): 48,8 \pm 0,8 Byr $\rightarrow$ constante $1,42 \times 10^{-11} / \mathrm{yr}$;

- Davis et al. (1977): 48,9 $\pm 0,4 \mathrm{Byr} \rightarrow$ constante 1,42 $\pm 0,01 \times 10^{-11} / \mathrm{yr}$;

- Pinson et al. (1963): 48,8 Byr confirmado por amostras datadas por outros métodos;

- Minster et al. (1982): 49,4 $\pm 0,3 \mathrm{Byr} \rightarrow$ constante $1,402 \pm 0,008 \times 10^{-11} / \mathrm{yr}$, com amostras com $\mathrm{U}-\mathrm{Pb}$ e $\mathrm{Rb}-\mathrm{Sr}$ precisas (isócronas concordantes).

Frente à estes valores variados, adota-se como convenção internacional o valor de $\mathrm{t}_{1 / 2}=$ 48,8 Byr, com constante de 1,42 x 10 $11 / \mathrm{yr}$ (Dickin, 1995a).

\section{$\underline{\text { Aplicações }}$}

Este sistema indica idades para eventos geológicos formadores de rochas com dados de ampla interpretação (Souza, 2009).

Uma das maneiras de obter estas idades se dá pelo método gráfico. Neste os valores obtidos para cada amostra cogenética são plotados em um diagrama isocrônico (figura II.1), onde a ordenada (y) correspondem às razões isotópicas $\mathrm{Sr}^{87} / \mathrm{Sr}^{86} \mathrm{e}$ a abscissa $(\mathrm{x})$ às razões $\mathrm{Rb}^{87} / \mathrm{Sr}^{86}$, e depois ligados por uma isócrona. A idade do conjunto de amostras é obtida calculando-se a tangente da divisão do ângulo que a isócrona forma com a horizontal pela constante de decaimento (White, 2009).

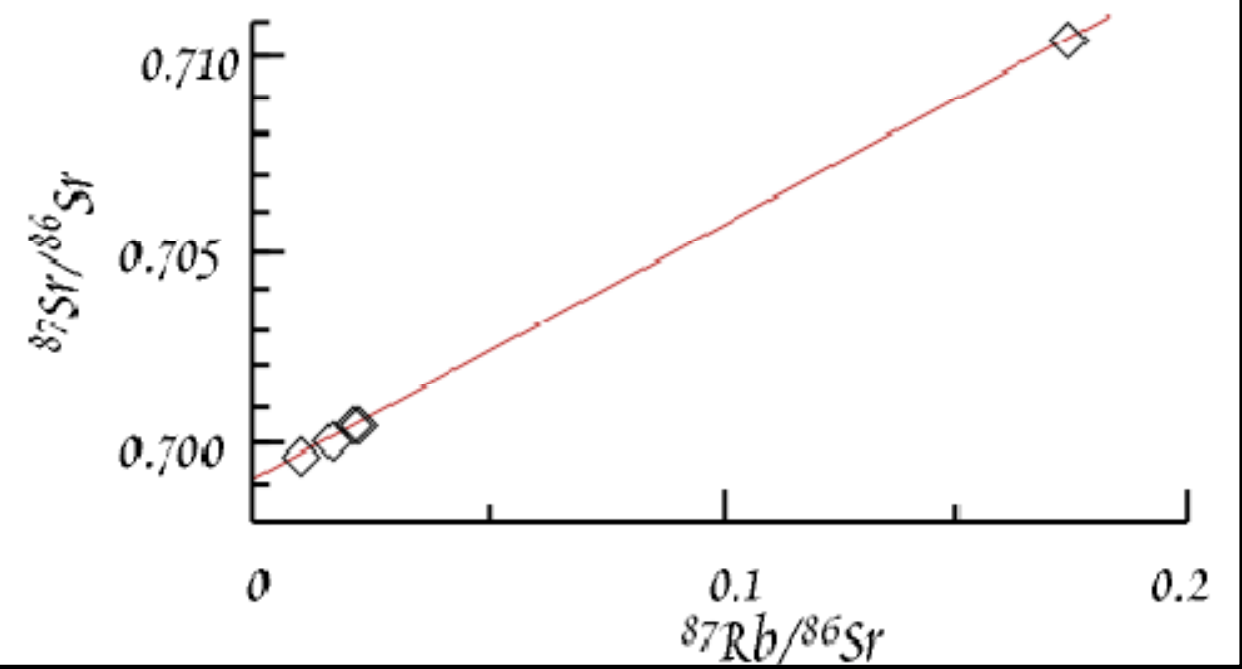

Figura II.1: Diagrama isocrônico do sistema Rb-Sr extraído de White (2009). A linha vermelha representa a isócrona gerada a partir de cinco amostras analisada pelo autor. 
Outra maneira de obter a idades do evento geológico seria através da equação abaixo (White, 2009):

$$
{ }^{87} \mathrm{Sr} /{ }^{86} \mathrm{Sr}=\left({ }^{87} \mathrm{Sr} /{ }^{86} \mathrm{Sr}\right)_{0}+\left({ }^{87} \mathrm{Rb} /{ }^{86} \mathrm{Sr}\right)(\lambda \mathrm{t})
$$

Onde $\lambda$ é a constante de decaimento, $\left({ }^{87} \mathrm{Sr} /{ }^{86} \mathrm{Sr}\right)_{0}$ é a razão inicial da Terra, ${ }^{87} \mathrm{Rb} /{ }^{86} \mathrm{Sr}$ da Terra é de 0,085 e $\mathrm{t}<<1 / \lambda$. A razão ${ }^{87} \mathrm{Sr} /{ }^{86} \mathrm{Sr}$ inicial da Terra pode ser estimada da razão inicial em meteoritos considerando que todo o sistema solar tinha ${ }^{87} \mathrm{Sr} /{ }^{86} \mathrm{Sr}$ uniforme no momento de sua formação. Uma vez formada, a Terra é um sistema fechado, portanto evolui segundo uma linha reta com inclinação proporcional à média de ${ }^{87} \mathrm{Rb} /{ }^{86} \mathrm{Sr}$ da Terra. A razão ${ }^{87} \mathrm{Sr} /{ }^{86} \mathrm{Sr}$ condrítica atual é de cerca de 0,725 , enquanto ${ }^{87} \mathrm{Sr} /{ }^{86} \mathrm{Sr}$ da Terra é de cerca de 0,705 (White, 2009).

Além de estimar uma idade para o evento gerador da rocha estudada, este sistema, quando aliado ao sistema $\mathrm{Sm}-\mathrm{Nd}$ pode fornecer dados sobre a origem da rocha-fonte, diferenciando reservatórios mantélicos daquelas de origem crustal (figura II.2), identificando o tipo de ambiente no qual o sedimento foi depositado (figura II.3).

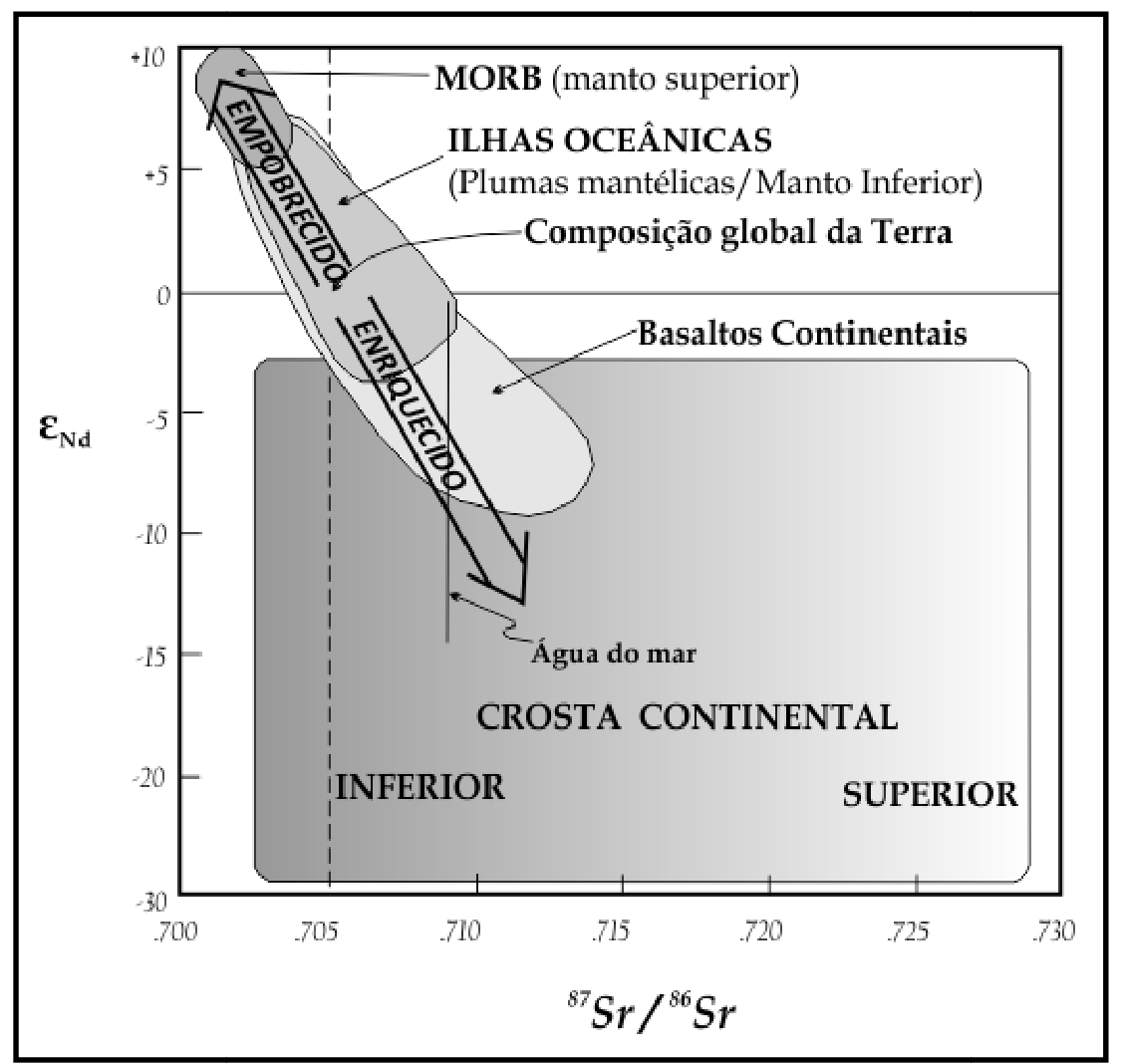

Figura II.2: gráfico $\varepsilon_{\mathrm{Nd}} v s .{ }^{87} \mathrm{Sr} /{ }^{86} \mathrm{Sr}$ extraído e traduzido de White (2009) com a delimitação dos campos de rochas de origem mantélica daquelas de origem crustal. Os campos "enriquecido" e "empobrecido" indicam onde reservatórios enriquecidos e empobrecidos em elementos incompatíveis seriam plotados. 
As razões iniciais ${ }^{87} \mathrm{Sr} /{ }^{86} \mathrm{Sr}$ também fornecem dados sobre o período de residência crustal da rocha analisada, pois quanto maior a razão, maior a quantidade do isótopo radiogênico. Rochas de assinatura juvenil tendem a apresentar menores razões isotópicas iniciais ${ }^{87} \mathrm{Sr} /{ }^{86} \mathrm{Sr}$ do que rochas de assinatura crustal (figuras II.2 e II.3).

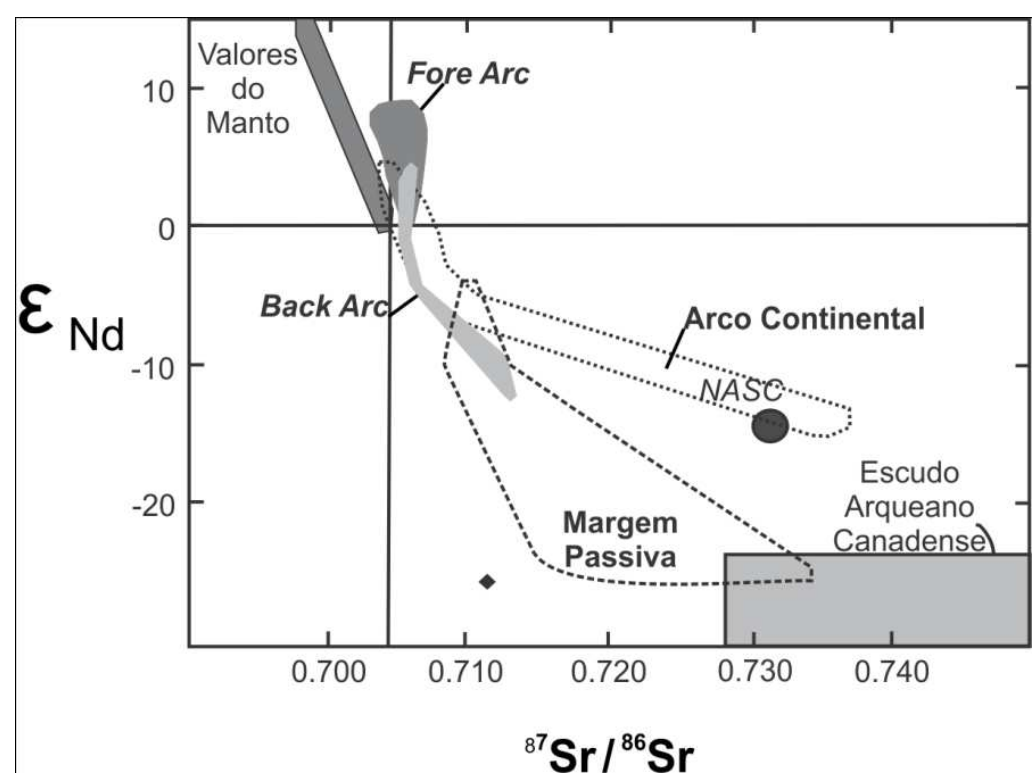

Figura II.3: gráfico $\varepsilon_{\mathrm{Nd}} v s .{ }^{87} \mathrm{Sr} /{ }^{86} \mathrm{Sr}$ extraído e modificado de McLennan et al (1990). Os campos delimitados se referem a amostras analisadas pelos autores provenientes de cada um dos ambientes de deposição identificados. NASC: North American Shale Composite (média das composições de pelitos norte americanos de idade no pósArqueano definida por Haskin, 1968).

\section{Desvantagens}

Segundo Dickin (1995a), a utilização deste sistema só é confiável quando relacionado a outros métodos de datação como Sm-Nd e U-Pb. Uma das razões para tal precaução é que a mobilidade destes elementos, principalmente do $\mathrm{Rb}$, traz desvantagens para geocronologia já que o sistema fechado assumido é violado. Toda rocha pode ser contaminada durante eventos pós-diagenéticos, como intemperismo e hidrotermalismo, assim a mobilidade de $\mathrm{Rb}$ e $\mathrm{Sr}$ pode resultar em idades imprecisas ou razões iniciais incorretas (White, 2009).

Outra desvantagem do método, no caso da datação de rochas metamórficas, é que o sistema só permanece fechado durante o evento térmico (permitindo a datação da cristalização da rocha) livre de processos hidrotermais que possam facilitar a drenagem de Sr para os fluidos percolantes (Dickin, 1995a).

No caso das rochas sedimentares, a datação $\mathrm{Rb}-\mathrm{Sr}$ depende da hipótese de que a concentração de Sr tenha sido homogeneizada durante a deposição ou início da diagênese, se mantendo como um sistema fechado até os dias atuais (Dickin, 1995a). Entretanto, o resultado 
também depende da natureza da fase mineral que contém Rb. Minerais detríticos, apesar de resistentes a aberturas de sistemas durante metamorfismo de soterramento, influenciam na quantidade de Sr presente na rocha. Por outro lado, minerais autigênicos, apesar de serem depositados diretamente na água do mar, apresentando homogeneidade de isótopo inicial de Sr, são altamente susceptíveis a recristalização após soterramento e podem não se comportar como sistemas fechados (Dickin, 1995a).

\section{II.5.1.2. Sistema isotópico Sm-Nd em rocha total}

O elemento químico $\mathrm{Sm}$ se apresenta na natureza na forma de sete isótopos, sendo ${ }^{147} \mathrm{Sm},{ }^{148} \mathrm{Sm}$ e ${ }^{149} \mathrm{Sm}$ radioativos. Os dois últimos tem meia-vida extensa, o que impede a medição da variação dos elementos radiogênicos ${ }^{144} \mathrm{Nd} \mathrm{e}{ }^{145} \mathrm{Nd}$. Para o isótopo ${ }^{147} \mathrm{Sm}$ a taxa de decaimento é de 6,54 x 10\%/ano ( $\lambda$ ) (Dickin, 1995b), com meia-vida de $1,06 \times 10^{11}$ anos (DePaolo, 1976), favorecendo a determinação da variação de ${ }^{143} \mathrm{Nd}$ radiogênico nos dias atuais. O decaimento se dá segundo a reação:

$$
{ }_{162}^{147} \mathrm{Sm} \rightarrow{ }^{143}{ }_{60} \mathrm{Nd}+{ }_{2}^{4} \mathrm{He}+\mathrm{Q}
$$

\section{Aplicações}

O sistema Sm-Nd foi utilizado como método de datação pela primeira vez por Lugmair (1974) e Lugmair et al (1975) que o aplicou para determinar idades de condritos e basalto lunar, e detectou que a razão ${ }^{143} \mathrm{Nd} /{ }^{144} \mathrm{Nd}$ indica as mudanças na abundância relativa de ${ }^{143} \mathrm{Nd}$ causada pelo decaimento de ${ }^{147} \mathrm{Sm}$.

DePaolo e Wasserburg (1976) foram os primeiros a determinar concentrações de Nd em rochas ígneas terrestres, o que gerou implicações para petrogênese e para história da crosta e manto terrestres. Neste mesmo trabalho, os autores entendem que se a linha de evolução CHUR (curva de evolução condrítica) define a razão inicial de rochas ígneas continentais através do tempo, a medição de ${ }^{143} \mathrm{Nd} /{ }^{144} \mathrm{Nd}$ e ${ }^{147} \mathrm{Sm} /{ }^{144} \mathrm{Nd}$ em qualquer rocha crustal daria uma idade modelo para a formação da rocha, ou da sua precursora, a partir da fonte de composição condrítica. Os autores expressam este modelo pela seguinte equação:

$$
\mathrm{T}^{\mathrm{Nd}}{ }_{\mathrm{CHUR}}=1 / \lambda \ln \left\{\left[1+\varepsilon_{\mathrm{Nd}(0)} \cdot \mathrm{I}_{\mathrm{CHUR}(0)} \cdot 10^{-4}\right] / \mathrm{f}_{\mathrm{Sm} / \mathrm{Nd}}\left({ }^{147} \mathrm{Sm} /{ }^{143} \mathrm{Nd}\right)_{\mathrm{CHUR}}\right\}
$$


Onde $f_{\mathrm{Sm} / \mathrm{Nd}}=\left\{\left[(\mathbf{S m} / \mathbf{N d})_{\mathrm{M}} /(\mathbf{S m} / \mathbf{N d})_{\mathrm{CHUR}}\right]-1\right\}$ e $\varepsilon_{\mathrm{Nd}(\mathbf{0})}=\left\{\left[\left({ }^{143} \mathbf{N d} /{ }^{144} \mathbf{N d}\right)_{\mathrm{M}} / \mathbf{I}_{\mathrm{CHUR}}\right.\right.$ (0) $]-1\} \cdot \mathbf{1 0}^{\mathbf{4}}$, considerando o sistema fechado com $(\mathrm{Sm} / \mathrm{Nd})_{\mathrm{CHUR}}=0,1936$ e $\mathrm{I}_{\mathrm{CHUR}(0)}=$ 0,511836, Partindo da premissa que a razão $\mathrm{Sm} / \mathrm{Nd}$ não sofreu modificações desde a separação do condrito (ou fonte mantélica), a $\mathrm{T}_{\mathrm{CHUR}}$ pode dar uma idade formação para vários litotipos. Além disso, os autores conseguiram diferenciar rochas basálticas continentais das oceânicas (medições de $\varepsilon_{1}{ }^{\mathrm{CHUR}}$ ), estabeleceram que a razão $\mathrm{Sm} / \mathrm{Nd}$ da Terra é aproximadamente igual à média dos meteoritos condríticos e sugeriram que razões ${ }^{143} \mathrm{Nd} /{ }^{144} \mathrm{Nd}$ diferentes para basaltos jovens distintos pode indicar fontes mantélicas distintas.

Segundo White (2009), valores negativos de $\varepsilon_{\mathrm{Nd}}$ implicam que durante a evolução da história da Terra a razão $\mathrm{Sm} / \mathrm{Nd}$ desta rocha ou de sua fonte tem sido menor que a do condrito, ou seja, o padrão de terras raras da rocha ou de sua fonte é enriquecido em ETRL. Por outro lado, valores positivos indicam que o padrão de terras raras da rocha ou de sua fonte é empobrecido em ETRL.

Além de idades-modelo, o sistema $\mathrm{Sm}-\mathrm{Nd}$ pode fornecer dados que, quando combinados com sistema Rb-Sr (figuras II.2 e II.3) e outros elementos traço, como a razão Th/Sc (figura II.4), indicam a assinatura geoquímica da área-fonte e do ambiente deposicional.

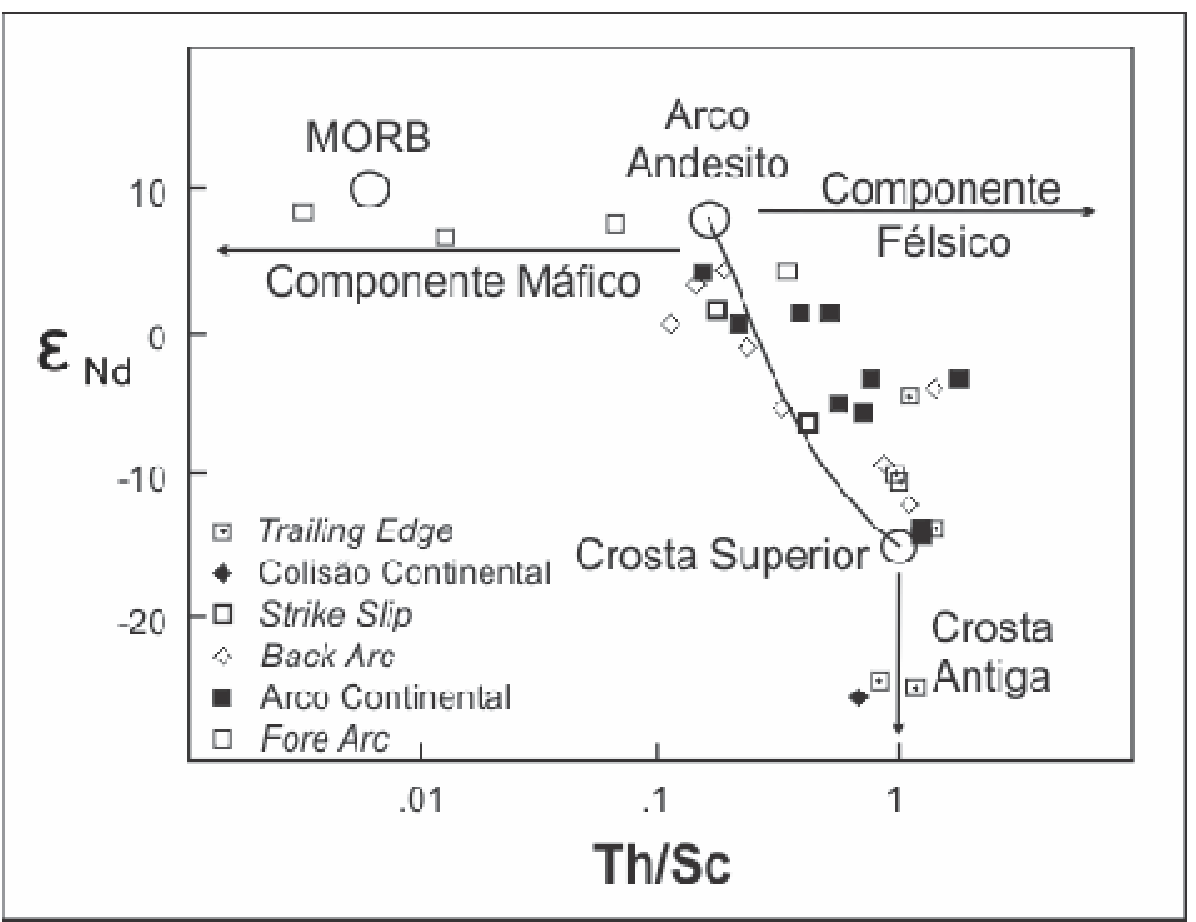

Figura II.4: Gráfico $\varepsilon_{\mathrm{Nd}} v s$. Th/Sc extraído e traduzido de McLennan et al. (1990). As amostras plotadas foram analisadas pelos autores. 


\section{Vantagens e Desvantagens}

A aplicabilidade da idade-modelo $\mathrm{Nd}$ para identificar proveniência sedimentar é eficiente porque é capaz de datar eventos anteriores à sedimentação e à erosão, pois as concentrações de Sm e Nd não são consideravelmente afetadas por estes eventos geológicos (Dickin, 1995b). Um grande fracionamento da razão $\mathrm{Sm} / \mathrm{Nd}$ é observado na formação da crosta, porém passados os estágios de formação de rochas crustais, a razão $\mathrm{Sm} / \mathrm{Nd}$ das mesmas tende a não se modificar (razão da maioria das rochas crustais é uniforme e ao redor de 0,13) (White, 2009). Estas constatações tornam a idade modelo, ou tempo de residência crustal, um método confiável de datação, pois, considerando ${ }^{143} \mathrm{Nd} /{ }^{144} \mathrm{Nd}$ e ${ }^{147} \mathrm{Sm} /{ }^{144} \mathrm{Nd}$ medidos, e assumindo que a razão ${ }^{147} \mathrm{Sm} /{ }^{144} \mathrm{Nd}$ era constante do tempo de formação, podemos estimar o tempo de residência destes elementos na crosta.

No caso do estudo de proveniência sedimentar, uma característica dos elementos terras raras é que não há mudanças significativas das abundâncias relativas destes elementos mesmo na produção de sedimentos muito finos a partir de rochas cristalinas. Isto significa que idades de residência crustal da rocha fonte podem ser calculadas a partir de rochas sedimentares (White, 2009). Entretanto, no caso de sedimentos que têm área-fonte heterogênea as idades $\mathrm{T}_{\mathrm{DM}}$ refletem a mistura de e sua interpretação deve ser feita associada a outros tipos de datação, como sistema isotópico U-Pb em zircão detrítico.

\section{II.5.2. Geoquímica Isotópica Mineral}

Quatro amostras foram preparadas para catação dos cristais (tabela II.4), sendo duas da Unidade Biotita Xisto na região da Serra das Bicas, uma da Unidade Biotita Xisto na região da Serra do Pombeiro e uma do quartzito da Formação Campestre descrita por Trouw et al (1980).

\begin{tabular}{lcc}
\hline \multirow{2}{*}{ Unidade Biotita Xisto } & Serra das Bicas & $C-331 ; C-337$ \\
\cline { 2 - 3 } & Serra do Pombeiro & $C-431$ \\
\hline \multirow{2}{*}{ Formação Campestre (Trouw et al., 1980) } & $C A R-I I-179$ \\
\hline
\end{tabular}

Tabela II.4: amostras analisadas para obtenção do sistema U-Pb em cristais de zircão detrítico. 
A preparação das amostras foi efetuada no LTA do IGc-USP (citado anteriormente) e no laboratório de Separação do Centro de Pesquisas Geocronológicas (CPGEO) do IGc-USP com orientação dos técnicos Vasco Antonio P. Loios, responsável pela separação, e Maurício Dias de Souza, responsável pela catação dos grãos, montagem dos mounts e obtenção das imagens de catodoluminescência. Foram seguidas as seguintes etapas:

(i) Limpeza das amostras e fragmentação das mesmas com marreta para obtenção de pedaços menores do que 3 (três) centímetros, aproximadamente;

(ii) Britagem em britador primário de mandíbulas de aço para cominuição das amostras em fragmentos menores do que 1 (um) centímetro;

(iii) Moagem em moinho de disco de tungstênio e peneiramento para a separação de frações de granulação entre 100 e $200 \mu \mathrm{m}$ e porções de grãos menores do que $200 \mu \mathrm{m}$.

(iv) Concentração de minerais densos por pressão de água e vibração em mesa de concentração Wiffley;

(vi) Na porção de minerais densos concentrados, separação dos minerais magnéticos com imã de mão;

(vii) Após a passagem do imã de mão, nova separação dos minerais magnéticos dos não magnéticos em separador magnético do tipo Frantz, a 0,5A;

(viii) A porção não magnética foi levada para capela de exaustão para passagem em bromofórmio $\left(\mathrm{CHBr}_{3}\right.$, densidade $\left.=2,89 \mathrm{~g} / \mathrm{cm}^{3}\right)$ para separação dos minerais mais densos do que $2,89 \mathrm{~g} / \mathrm{cm}^{3}$;

(ix) $\mathrm{Na}$ porção de minerais mais densos que o bromofórmio, nova separação de minerais magnéticos a $0,5 \mathrm{~A}$ dos não magnéticos foi realizada no Frantz a 0,5A;

(x) A porção não magnética foi levada a capela de exaustão para passagem em iodeto de methyleno $\left(\mathrm{CH}_{2} \mathrm{I}_{2}\right.$, densidade $\left.=3,32 \mathrm{~g} / \mathrm{cm}^{3}\right)$ para separação dos minerais mais densos do que $3,32 \mathrm{~g} / \mathrm{cm}^{3}$;

(xi) A porção mais densa do que o iodeto de methyleno foi analisada em uma lupa Leika para observar a existência (ou não) de cristais de zircão;

(xii) As amostras preparadas foram encaminhadas para catação dos cristais em lupa e posterior montagem de mounts com utilização de resina epoxy;

(xiii) Imagens de catodoluminescência foram obtidas em EDS do tipo EDS-X-MAX da marca Oxford, a partir de detector CENTAUROS, para a identificação de inclusões e microfraturas nos cristais. Estas imagens foram utilizadas para auxiliar no posicionamento do 
feixe de laser durante as análises no LA-MC-ICP MS (laser ablation multi-collector inductively coupled plasma mass spectrometry). Nesta etapa, após a análise de EDS (Energy Dispersive Spectroscopy), foi constatado que os grãos separados da amostra C-331 não eram de zircão. A amostra C-337 foi selecionada para substituí-la, mas descartada na etapa (xi) por não apresentar cristais de zircão visíveis em lupa. Portanto, foram encaminhadas para a próxima etapa as amostras C-431 e CAR-II-179;

(xiv) As idades de proveniência a partir das medidas das razões ${ }^{206} \mathrm{~Pb} /{ }^{238} \mathrm{U}$ e ${ }^{207} \mathrm{~Pb} /{ }^{235} \mathrm{U}$ em zircão detrítico foram obtidas por LA-MC-ICP MS, com feixe de $29 \mu \mathrm{m}$, com auxílio do técnico responsável Walter Mauricio Sproesser no CPGEO do IGc-USP.

\section{II.5.2.1. Sistema isotópico U-Pb em zircão detrítico}

A análise do sistema Urânio-Chumbo (U-Pb) em cristais detríticos de zircão foi escolhida para obtenção de idades de proveniência por ser um método consistente, preciso, de fácil obtenção e de ampla utilização na literatura (Fedo et al., 2003). Além disso, o zircão é resistente a ações do intemperismo, diagênese e metamorfismo, mantendo o sistema fechado em condições extremas de temperatura e pressão, preservando idades mais antigas, facilmente sobrepostas em outros sistemas isotópicos.

Por causa de suas características refratárias o zircão pode ser encontrado praticamente em todos os depósitos sedimentares e metassedimentares, e por isso exerce um papel importante no entendimento da proveniência dos mesmos (Fedo et al., 2003).

A determinação das razões ${ }^{206} \mathrm{~Pb} /{ }^{238} \mathrm{U}$ e ${ }^{207} \mathrm{~Pb} /{ }^{235} \mathrm{U}$ em zircões detríticos por LA-MCICPMS foi a escolhida neste trabalho porque este método permite a análise de diversos grãos em um espaço de tempo relativamente curto, permitindo que uma grande variedade de dados úteis para análises de proveniência possam ser avaliados.

\section{Método}

$\mathrm{Na}$ natureza encontram-se quatro isótopos de $\mathrm{Pb},{ }^{204} \mathrm{~Pb},{ }^{206} \mathrm{~Pb},{ }^{207} \mathrm{~Pb}$ e ${ }^{208} \mathrm{~Pb}$, sendo apenas o primeiro não radiogênico, ou seja, não é produto do decaimento radioativo de urânio (U) ou tório (Th). Os isótopos radioativos que decaem para os isótopos radiogênicos, com suas respectivas meia-vida e a constante de decaimento são mostrados na tabela II.5 a partir dos dados de Jaffey et al. (1971) em Dickin (1995c). 


\begin{tabular}{ccc}
\hline Equação de decaimento & $\boldsymbol{t}_{\mathbf{1} / \mathbf{2}}, \mathbf{G a}$ & Constante de decaimento $\boldsymbol{\lambda}$, ano $^{-1}$ \\
\hline${ }^{238} \mathrm{U} \rightarrow{ }^{206} \mathrm{~Pb}$ & 4,47 & $1,55125 \times 10^{-10}$ \\
\hline${ }^{235} \mathrm{U} \rightarrow{ }^{207} \mathrm{~Pb}$ & 0,704 & $9,8485 \times 10^{-10}$ \\
\hline${ }^{232} \mathrm{Th} \rightarrow{ }^{208} \mathrm{~Pb}$ & 14,01 & $0,49475 \times 10^{-10}$ \\
\hline
\end{tabular}

Tabela II.5: dados de Jaffey et al. (1971) para meia-vida $\left(t_{1 / 2}\right)$ e constante de decaimento das reações que produzem os três elementos radioativos de $\mathrm{Pb}$ presentes na natureza (extraído de Dickin, 1995c).

O decaimento de cada isótopo radioativo se dá segundo reações que passam por diversos estágios e elementos intermediários que tem meia-vida relativamente curta, variando de milisegundos a minutos (White, 2009), o que os torna dispensáveis em trabalhos geoquímicos (figura II.5). Entretanto, alguns destes elementos intermediários possuem meiavida variável de dias a centenas de milhares de anos e provêm informações úteis sobre processos geológicos de curta duração, sendo de grande eficácia na datação de sedimentos $\left({ }^{238} \mathrm{U} \rightarrow{ }^{234} \mathrm{U}\right.$ : meia-vida de 246,000 anos) ou na determinação de taxas de sedimentação e idades de lavas $\left({ }^{238} \mathrm{U} \rightarrow{ }^{230} \mathrm{Th}\right)$ (White, 2009).

\section{$\underline{\text { Aplicações }}$}

Uraninita e monazita foram os primeiros minerais utilizados em geocronologia $\mathrm{U}-\mathrm{Pb}$, devido sua tendência de incorporar grandes concentrações de $\mathrm{U}$ e pouco $\mathrm{Pb}$ comum inicial. Entretanto, o zircão se tornou o mineral mais analisado, pois além de ser um mineral rico em U é encontrado na maioria das rochas intermediárias a ácidas, além de ser resistente a processos geológicos como metamorfismo, intemperismo, diagênese e hidrotermalismo.

$\mathrm{O}$ sistema $\mathrm{U}-\mathrm{Pb}$ raramente se mantém fechado em rochas silicáticas devido à mobilidade do $\mathrm{Pb}$ e do $\mathrm{U}$ em condições de metamorfismo de baixo grau e intemperismo, dificultando a obtenção de idades concordantes em análises de rocha total. Porém, como a relação entre ${ }^{235} \mathrm{U}$ e ${ }^{238} \mathrm{U}$ com ${ }^{207} \mathrm{~Pb}$ e ${ }^{206} \mathrm{~Pb}$ é quimicamente coerente, a obtenção de idades mesmo em sistemas perturbados, se torna possível. 
Uma das técnicas que exploram tal relação é a que analisa o sistema U-Pb em cristais de zircão, partindo da premissa que o zircão incorporoa U durante sua cristalização, mas não $\mathrm{Pb}$, tornando as equações abaixo confiáveis:

$$
\begin{aligned}
& { }^{206} \mathrm{~Pb}={ }^{238} \mathrm{U}\left(\mathrm{e}^{\lambda}{ }_{238}^{\mathrm{t}}-1\right) \\
& { }^{207} \mathrm{~Pb}={ }^{235} \mathrm{U}\left(\mathrm{e}^{\lambda}{ }_{235}{ }^{\mathrm{t}}-1\right)
\end{aligned}
$$

Onde $\mathrm{Pb}$ representa apenas o $\mathrm{Pb}$ radiogênico.

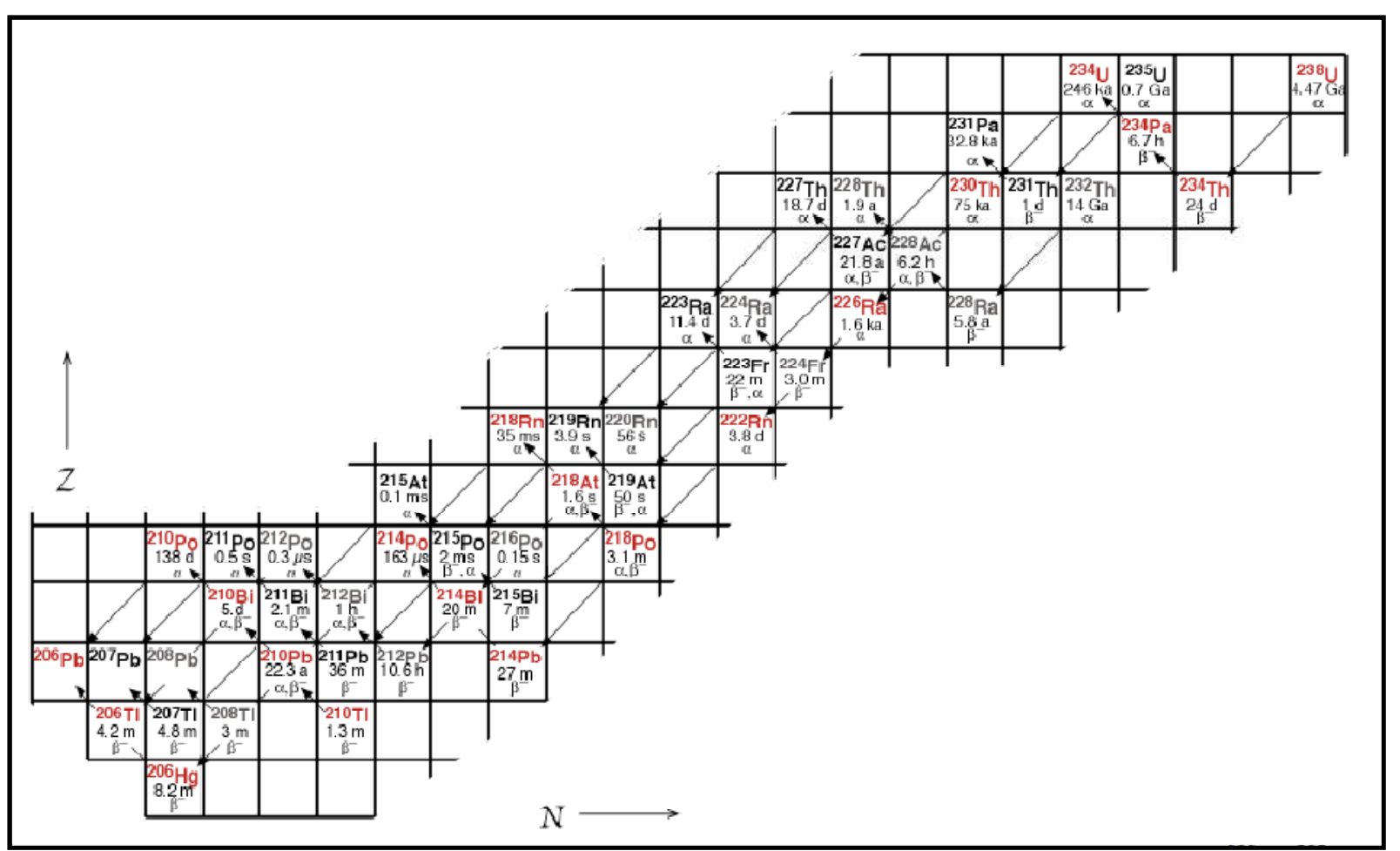

Figura II.5: parte da tabela de nuclídeos extraída de White (2009) que mostra os elementos intermediários que participam das reações de decaimento de ${ }^{238} \mathrm{U},{ }^{235} \mathrm{U}$ e ${ }^{232} \mathrm{Th}$ para ${ }^{206} \mathrm{~Pb},{ }^{207} \mathrm{~Pb}$ e ${ }^{208} \mathrm{~Pb}$. Em vermelho os nuclídeos da série ${ }^{238} \mathrm{U}$, em preto os nuclídeos da série ${ }^{235} \mathrm{U}$ e em cinza os nuclídeos da série ${ }^{232} \mathrm{Th}$ (o tempo de cada decaimento se encontra abaixo do elemento).

A partir do ${ }^{204} \mathrm{~Pb}$, ou $\mathrm{Pb}$ comum, pode-se construir diagramas isocrônicos (figura II.6) que permitem a datação de rochas utilizando-se as seguintes equações:

$$
\begin{aligned}
& \left({ }^{206} \mathrm{~Pb} /{ }^{204} \mathrm{~Pb}\right)_{\mathrm{P}}=\left({ }^{206} \mathrm{~Pb} /{ }^{204} \mathrm{~Pb}\right)_{\mathrm{I}}+{ }^{238} \mathrm{U} /{ }^{204} \mathrm{~Pb}\left(\mathrm{e}^{\lambda}{ }_{238}{ }^{\mathrm{t}}-1\right) \\
& \left({ }^{207} \mathrm{~Pb} /{ }^{204} \mathrm{~Pb}\right)_{\mathrm{P}}=\left({ }^{207} \mathrm{~Pb} /{ }^{204} \mathrm{~Pb}\right)_{\mathrm{I}}+{ }^{235} \mathrm{U} /{ }^{204} \mathrm{~Pb}\left(\mathrm{e}^{\lambda}{ }_{235}{ }^{\mathrm{t}}-1\right)
\end{aligned}
$$


Sendo, $\left({ }^{206 ; 207 ; 208} \mathbf{P b} /{ }^{204} \mathbf{P b}\right)_{\mathbf{P}}$ a abundância nos dias atuais e $\left({ }^{\mathbf{2 0 6 ; 2 0 7 ; 2 0 8}} \mathbf{P b} /{ }^{204} \mathbf{P b}\right)_{\mathbf{I}}$ a abundância inicial.

Sistemas fechados dão valores concordantes de $t$ quando as composições isotópicas são inseridas do lado esquerdo das equações acima. Quando estas idades concordantes são plotadas no diagrama isocrônico, definem uma curva denominada CONCÓRDIA DE WETHERILL (figura II.6), que pode ser desenhada pela substituição das constantes de decaimento e valores sucessivos de $t$ no lado direito das equações, e plotando os resultados para cada valor de $t$ (Dickin, 1995c).

As frações iniciais de ${ }^{204} \mathrm{~Pb}$ incorporado pelo cristal de zircão, no caso de cristais de zircão com $\mathrm{Pb}$ comum baixo, são corrigidas estimando o $\mathrm{Pb}$ comum de um modelo de evolução de $\mathrm{Pb}$ terrestre geral (Stacey \& Kramers, 1975).

Ahrens (1955) obteve idades U-Pb para monazita e uraninita que plotavam fora da concórdia, porém seguiam uma reta, denominada pelo mesmo autor de DISCÓRDIA (figura II.6). O método aplicado quando há discordância dos dados é conhecido como idades de intersecção superior (Dickin, 1995c), e fornece idades através do prolongamento da discórdia até intersecção desta com a concórdia na sua porção superior $\left(\mathrm{t}_{1}\right)$.

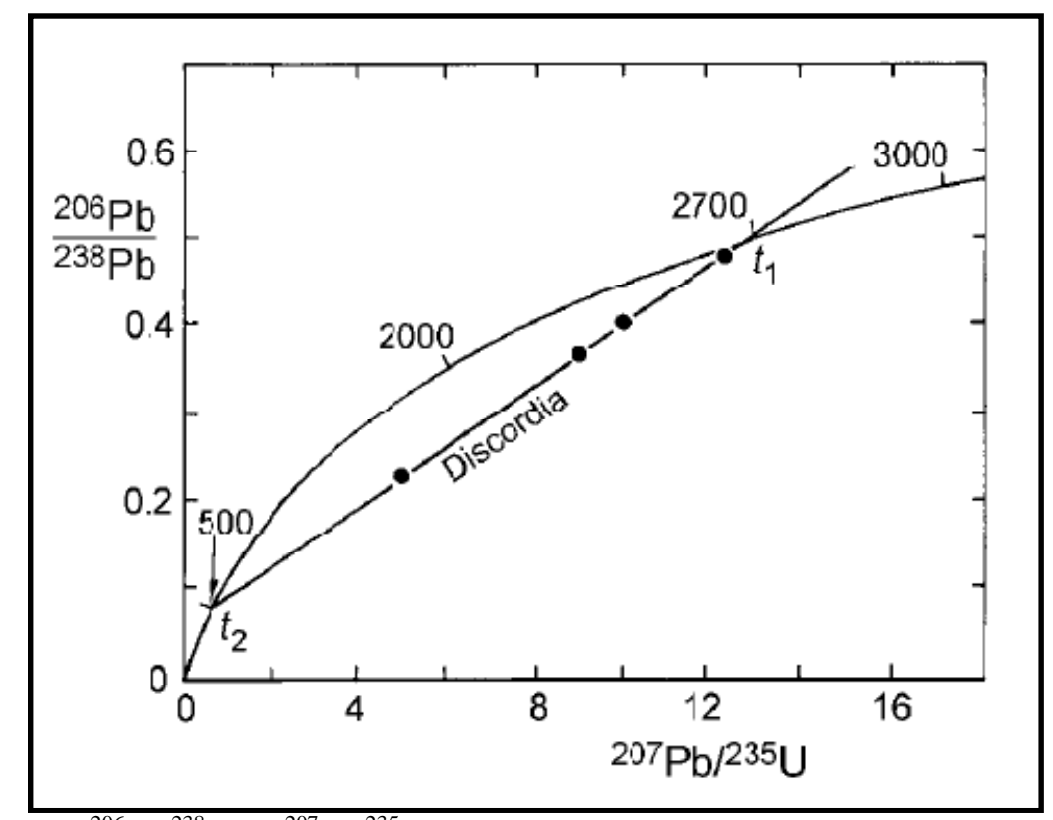

Figura II.6: Diagrama ${ }^{206} \mathrm{~Pb} /{ }^{238} \mathrm{U} v s .{ }^{207} \mathrm{~Pb} /{ }^{235} \mathrm{U}$ extraído de Dickin (1995c) com concórdia calibrada em Ma. A discórdia foi gerada por perdas de chumbo variadas em minerais do Zimbabwe ricos em U com 2700 Ma de idade.

Visando a obtenção da melhor intersecção da discórdia com a concórdia é preferível analisar várias frações do zircão que perdeu diferentes quantidades de $\mathrm{Pb}$, o que provoca uma 
regressão linear nos resultados. Esta regressão não pode ser resolvida algebricamente para fornecer idades superiores e inferiores de intersecção, assim, são calculadas graficamente em relação à uma concórdia calibrada, ou por computador.

Se processos de perda de $\mathrm{Pb}$ atuaram em diferentes tempos na história do zircão a discórdia será difusa, caindo longe da intersecção superior (Dickin, 1995c). Este espalhamento dos dados causa pouca incerteza na superior, mas muita na inferior. Para diminuir a incerteza, coloca-se barras de erros, considerando sua discordância (Davis,1982). Por outro lado, Krogh (1982a,b) sugere que ao invés de refinar os dados matematicamente, seria melhor remover $\mathrm{Pb}$ discordante da amostra antes da análise, excluindo, por exemplo, os zircões metamíticos (ricos em impurezas, como $\mathrm{Fe}$ ) no separador magnético do tipo Frantz.

Histogramas de distribuição de probabilidade e densidade (figura II.7) são muito utilizados em estudos de proveniência sedimentar, pois consideram os erros dos dados e gera uma distribuição de probabilidade de toda a amostra que varia individualmente para cada idade obtida (Fedo et al., 2003). Além disso, estes histogramas apresentam os vários grupos de idades, quando existentes, de maneira clara e de fácil visualização, entendimento e interpretação.

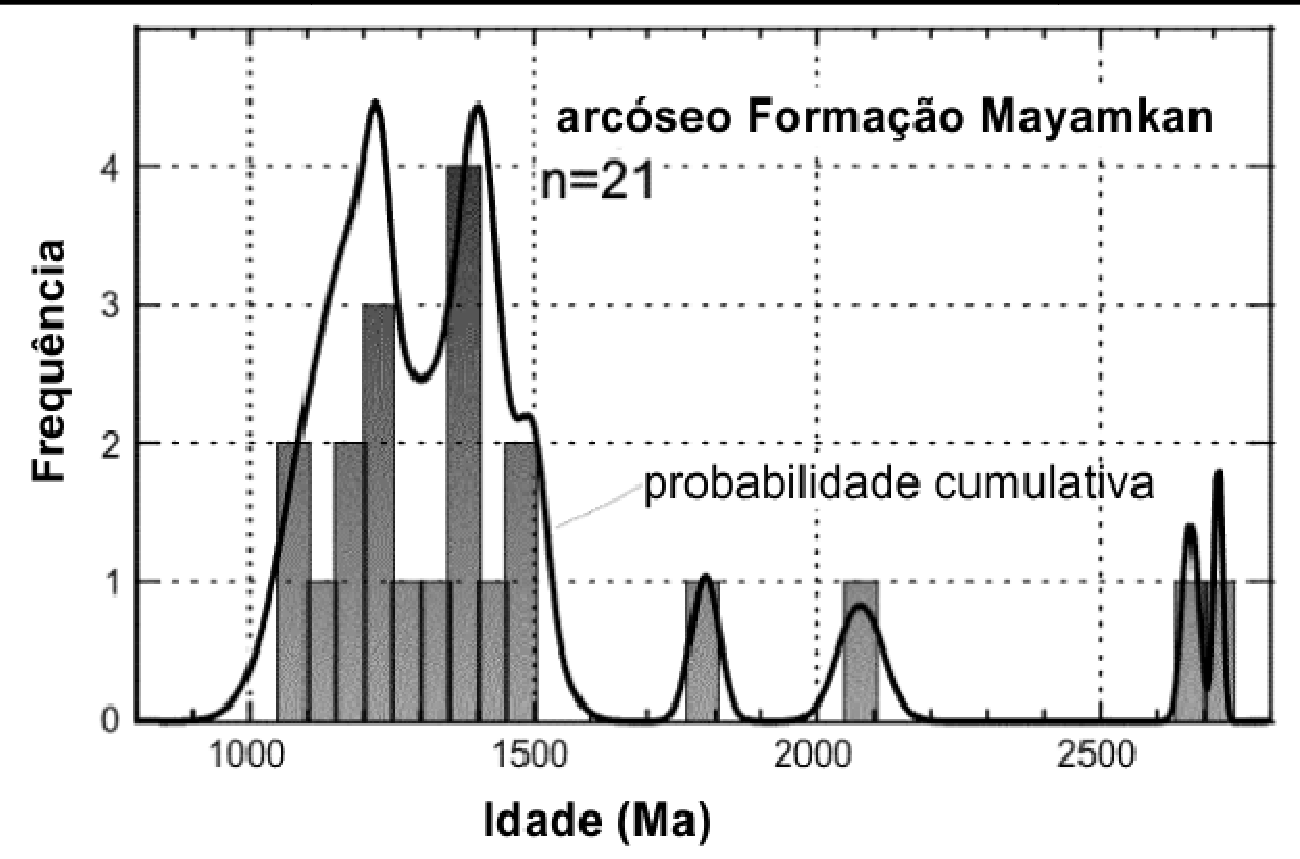

Figura II.7: histograma de distribuição de probabilidade e densidade extraído e traduzido de Fedo et al. (2003) com dados de idades ${ }^{207} \mathrm{~Pb} /{ }^{206} \mathrm{~Pb}$ de zircões detríticos analisadps por Rainbird et al (1998). 


\section{Perda de chumbo}

Segundo Holmes (1954) quando as idades ${ }^{206} \mathrm{~Pb} /{ }^{238} \mathrm{U}$ e ${ }^{207} \mathrm{~Pb} /{ }^{235} \mathrm{U}$ são discordantes indicam que houve perda de $\mathrm{Pb}$ pelo cristal. Neste mesmo trabalho o autor definiu que a discórdia estaria associada a perda de $\mathrm{Pb}$ por difusão.

Wetherill (1956) estabeleceu a perda de chumbo episódica em dois momentos (figura II.6): $\mathrm{t}_{1}$ relativa o tempo de formação do mineral; e $\mathrm{t}_{2}$ relativa a eventos termais, como metamorfismo, intrusão, extrusão. Por outro lado, Russel e Ahrens (1957) estabeleceram que a perda de $\mathrm{Pb}$ pode ocorrer durante o decaimento, quando os membros intermediários seriam ejetados em micro-fissuras do mineral, produzidas pela radiação, e depois perdidos por difusão ou por lixiviação.

Outra explicação para a perda de chumbo foi dada por Goldrich e Mudrey (1972) que sugeriram que os danos da radiação seriam responsáveis por formar uma rede micro-capilar no cristal que seria preenchida por fluidos. $\mathrm{O} \mathrm{Pb}$ difuso nestes fluidos seria perdido durante o soerguimento do embasamento, que causaria dilatação do mineral, expelindo os fluidos.

\section{Condições estabelecidas para utilização do sistema $\mathrm{U}-\mathrm{Pb}$ como geocronômetro}

Em um primeiro momento, deve-se identificar se o sistema permaneceu fechado. Além disso, deve-se assumir que não há interferência da cadeia de fissão do ${ }^{235} \mathrm{U}$, o que é muito raro de ocorrer na natureza, mas é possível.

A partir do momento que estas premissas forem confirmadas os sistemas ${ }^{238} \mathrm{U}-{ }^{206} \mathrm{~Pb} \mathrm{e}$ ${ }^{235} \mathrm{U}-{ }^{207} \mathrm{~Pb}$ apresentarão idades concordantes, exceto quando há perdas de chumbo pelo cristal.

\section{II.6. Elaboração da dissertação}

A dissertação foi elaborada utilizando o programa Word, versões 2003 e 2007, As figuras foram editadas no programa Corel Draw, versões 12 e X3 e os mapas confeccionados no programa ArcGis 9.0 utilizando como base as folhas topográficas citadas no item II.2, que por sua vez foram adquiridas no site do Instituto Brasileiro de Geografia e Estatística (IBGE). 


\section{Capítulo III}

\section{ProveniênCia Sedimentar}

O estudo de proveniência sedimentar conjuga diversas áreas da geologia, como mineralogia, geoquímica, geocronologia, sedimentologia, petrologias ígnea e metamórfica, sendo muito utilizado na caracterização de contexto tectônico em escala regional e local (Haughton et al., 1991). Análises químicas e texturais de minerais detríticos (em sedimentos inconsolidados ou rochas sedimentares), bem como as análises químicas de rochas sedimentares são as ferramentas mais utilizadas na literatura nos dias atuais para a realização destes estudos (McLennan et al., 1990), pois diferentes tipos de rochas tendem a apresentar diferentes assembléias minerais que lhes são características (Pettijohn, 1975).

Considerando que, apesar de muitas vezes crucial, a análise de um só mineral não pode ser o único fator determinante da proveniência ou do contexto tectônico, sendo necessária a avaliação do contexto regional e de toda a assembléia mineral detrítica que compõe a amostra, a observação dos seguintes mecanismos que controlam a assembléia mineral, e consequentemente a composição global, da rocha sedimentar (figura III.1) é crucial para a identificação de sua proveniência (Morton e Hallsworth, 1999):

Intemperismo: pode afetar a rocha-fonte, modificando sua composição antes da incorporação do sedimento no sistema de transporte, ou da rocha sedimentar antes da amostragem no afloramento;

Abrasão mecânica: ocasionada pelo transporte, pode diminuir a diversidade mineralógica, pois causa cominuição dos grãos de dureza menor;

Processos hidráulicos: refletido pelos parâmetros granulométricos do sedimento (como tamanho do grão e seleção), controlam a abundância absoluta e relativa dos minerais durante o transporte e a deposição;

Variações nos procedimentos laboratoriais: atenção a possíveis erros cometidos durante o tratamento químico, na separação e na identificação do mineral. 


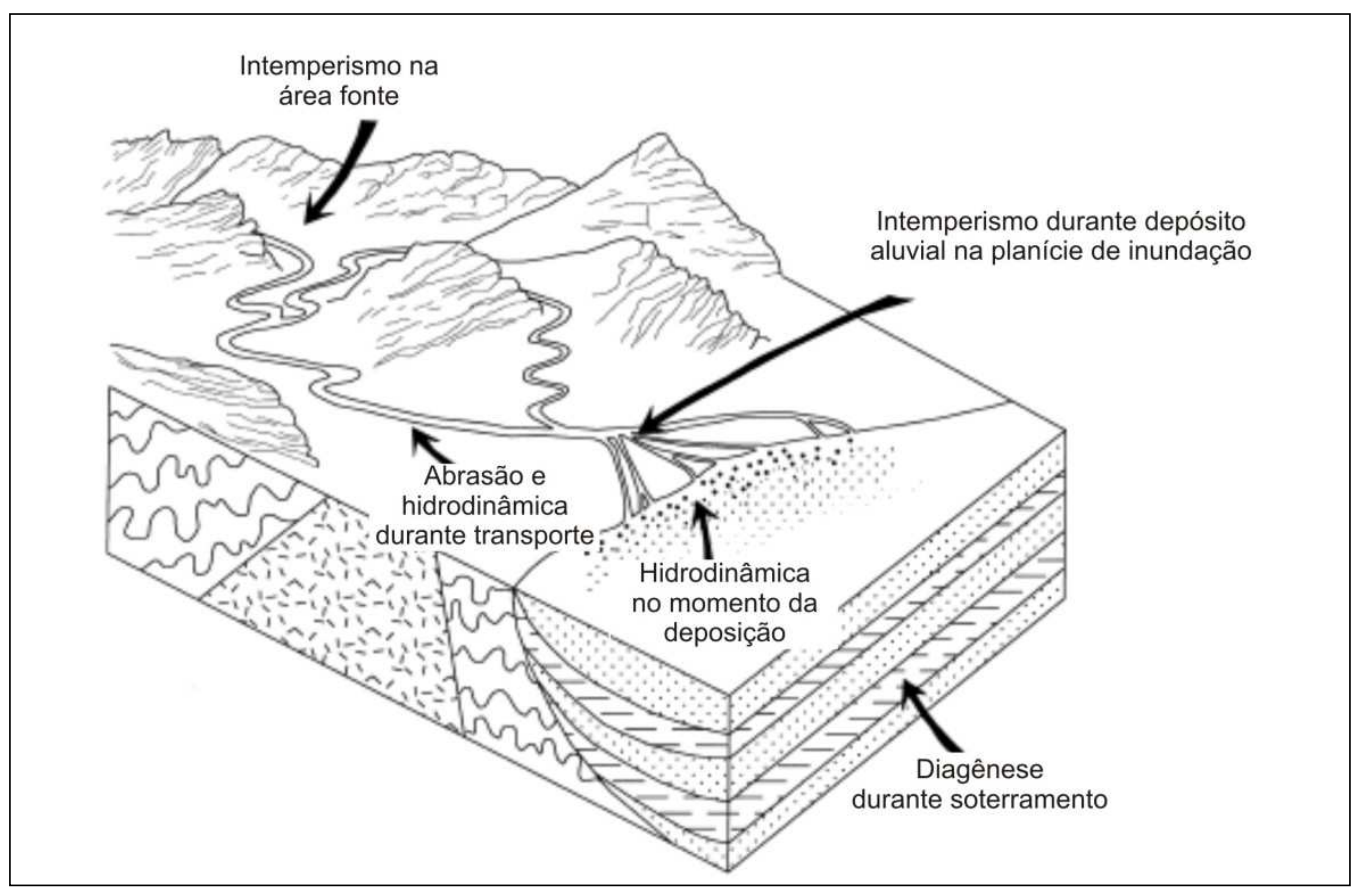

Figura III.1: esquema em bloco de um ambiente de sedimentação com os principais mecanismos que controlam a assembléia mineral de uma rocha sedimentar (Morton e Hallsworth, 1999).

No caso de rochas metassedimentares, além de todos estes parâmetros relacionados acima, deve-se considerar todas as modificações físicas e químicas que podem ocorrer durante o aumento de temperatura e pressão e/ou deformação. Rochas metamorfisadas a baixo grau raramente sofrem alterações químicas consideráveis, exceto nos casos em são afetadas por processos hidrotermais, ou forte intemperismo químico após sua formação. Por outro lado, rochas metamórficas de alto grau são facilmente modificadas quimicamente, perdendo elementos químicos para fluidos hidrotermais exógenos ou endógenos, expelidos com o aumento de temperatura e pressão combinado com processos deformacionais.

Em rochas metamórficas deformadas de faixas orogênicas, a obliteração freqüente das estruturas sedimentares, dificulta, ou inviabiliza o estudo das condições e do ambiente de deposição. Neste caso, o estudo da composição química destas rochas, aliado ao estudo detalhado das estruturas deformacionais, das condições de metamorfismo e do posicionamento estratigráfico, torna-se um importante objeto de estudo para caracterização da fonte do sedimento original, as características do ambiente tectônico durante a sedimentação e o grau de alteração/reciclagem do sedimento a partir da área-fonte. A caracterização geoquímica da rocha é feita a partir de análises de elementos traços e isotópicos, pois tais elementos não são afetados significativamente por processos como intemperismo, erosão, diagênese e metamorfismo (McLennan et al, 1990). 


\section{III.1. Proveniência Sedimentar - Aplicações}

Dentre as principais aplicações dos estudos de proveniência estão:

(i) Evolução crustal: a composição química de rochas sedimentares fornece dados que indicam a composição da crosta continental superior (Taylor e McLennan, 1985), sendo um importante meio para entender e determinar como a mesma evolui através do tempo geológico (McLennan e Taylor, 1991). Variações de elementos-traço nos minerais e nas rochas indicam mudanças composicionais da crosta superior, enquanto dados isotópicos podem detalhar o padrão de geração de crosta e a importância da reciclagem sedimentar (Haughton et al., 1991);

(ii) Caracterização de crosta erodida: registros detríticos muitas vezes são os únicos elementos que restam de blocos crustais e de níveis erodidos, sendo um dos únicos meios de identificação de ambientes tectônicos quando apenas um registro parcial é preservado in situ (ex.: magmatismo de arco preservado);

(iii) Implicações paleoclimáticas: determinadas por parâmetros mineralógicos e químicos que diferenciam, através de índices pré-estabelecidos, se a rocha sofreu intemperismo químico e/ou físico, com conseqüências para o diagnóstico do clima vigente na época da sedimentação;

(iv) Contexto tectônico: determinação de reciclagem, idades precisas e ambientes tectônicos ativos identificados por mudanças brusca de sedimentação;

(v) Correlação estratigráfica de sub-superfície: feita principalmente por minerais pesados e por combinação de geoquímica de elementos maiores e traços.

\section{III.2. Proveniência sedimentar - Métodos de determinação}

Os três principais métodos de avaliação de proveniência, ambiente deposicional e contexto tectônico de rochas sedimentares observados na literatura são:

(i) Análise mineralógica petrográfica dos minerais detríticos;

(ii) Análise química mineral;

(iii) Análise geoquímica de rochas sedimentares. 


\section{III.2.1. Análise mineralógica petrográfica de minerais detríticos}

Baseada principalmente em minerais pesados (tabela III.1), esta análise é feita com montagem de grãos de granulação entre 0,062 e 0,125 mm em lâminas delgadas, pois esta é a faixa com maior concentração de minerais pesados.

\section{CLASSIFICAÇÃO DE MINERAIS PESADOS COMUNS QUANTO À ESTABILIDADE FÍSICA E QUÍMICA (PETTIJOHN ET AL., 1972)}

\section{ULTRAESTÁVEIS Rutilo (4,18-4,25); zircão (4,68); turmalina (3,0-3,25); anatásio $(3,9)$}

Apatita $(3,15-3,20)$; Fe-granada $(3,5-4,3)$; estaurolita $(3,65-3,75)$;
monazita $(4,6-5,4)$; biotita $(2,8-3,2)$; ilmenita $(4,7)$; magnetita $(5,18)$

\section{MODERADAMENTE Epidoto (3,35-3,45); cianita (3,55-3,66); Fe-granada; sillimanita $(3,23)$; \\ ESTÁVEIS \\ titanita $(3,40-3,55)$; zoisita $(3,35)$}

INSTÁVEIS

Hornblenda (3,0-3,4); actnolita (3,1-3,3); augita (3,2-3,4); diopsídio (3,2); hiperstênio $(3,4-3,5)$; andaluzita $(3,16-3,20)$

\section{MTO INSTÁVEIS}

Olivina $(3,27-4,37)$

Tabela III.1: classificação de estabilidade dos principais minerais pesados utilizados em estudos de proveniência extraída de Pettijohn et al. (1972). Os números em parênteses referem-se à densidade de cada mineral em $\mathrm{g} / \mathrm{cm}^{3}$,

A separação dos minerais é feita com líquidos densos (tabela III.2) e a determinação dos minerais em microscópio petrográfico através da análise das características individuais e próprias de cada espécie (Mange e Maurer, 1992), como relevo, cor, pleocroísmo, forma, clivagem, extinção, birrefringência, elongação, caráter óptico, ângulo $2 \mathrm{~V}$, arredondamento e texturas superficiais, como feições de dissolução (figuras III.2 e III.3). A observação destas características, além de determinar diferentes minerais, auxilia na separação de minerais de um mesmo grupo.

A contagem dos grãos para determinar sua frequiência na lâmina em número e porcentagem é o último passo antes da aplicação dos dados em padrões e índices préestabelecidos. 


\begin{tabular}{cccc}
\hline LíQUIDO & COMPOSIÇão & $\begin{array}{c}\text { DENSIDADE } \\
\text { MÁXIMA }\end{array}$ & SOLVENTE \\
\hline Bromofórmio & $\mathrm{CHBr}_{3}$ & 2,88 & $\begin{array}{c}\text { Benzol, xileno, tetracloreto de } \\
\text { carbono, etilenobromida, álcool }\end{array}$ \\
\hline Tetrabromoetano & $\mathrm{C}_{2} \mathrm{H}_{2} \mathrm{Br}_{4}$ & 2,95 & $\begin{array}{c}\text { Benzol, xileno, tetracloreto de } \\
\text { carbono, etilenobromida }\end{array}$ \\
\hline $\begin{array}{c}\text { Solução de Thoulet } \\
\text { Iodeto de Metileno }\end{array}$ & $\mathrm{KI}^{+\mathrm{HgI}_{2} \text { (aq.) }}$ & 3,19 & $\mathrm{H}_{2} \mathrm{O}$ \\
\hline $\begin{array}{c}\text { Solução de Clerici } \\
\text { Politungstato de } \\
\text { sódio }\end{array}$ & $\begin{array}{c}\text { Malonato + formiato } \\
\text { de tálio (aq.) }\end{array}$ & 4,2 & $\begin{array}{c}\text { Benzol, xileno, tetracloreto de } \\
\text { carbono }\end{array}$ \\
\hline
\end{tabular}

Tabela III.2: principais líquidos densos utilizados na separação de minerais detríticos. A densidade máxima é dada $\mathrm{em} \mathrm{g} / \mathrm{cm}^{3}$.

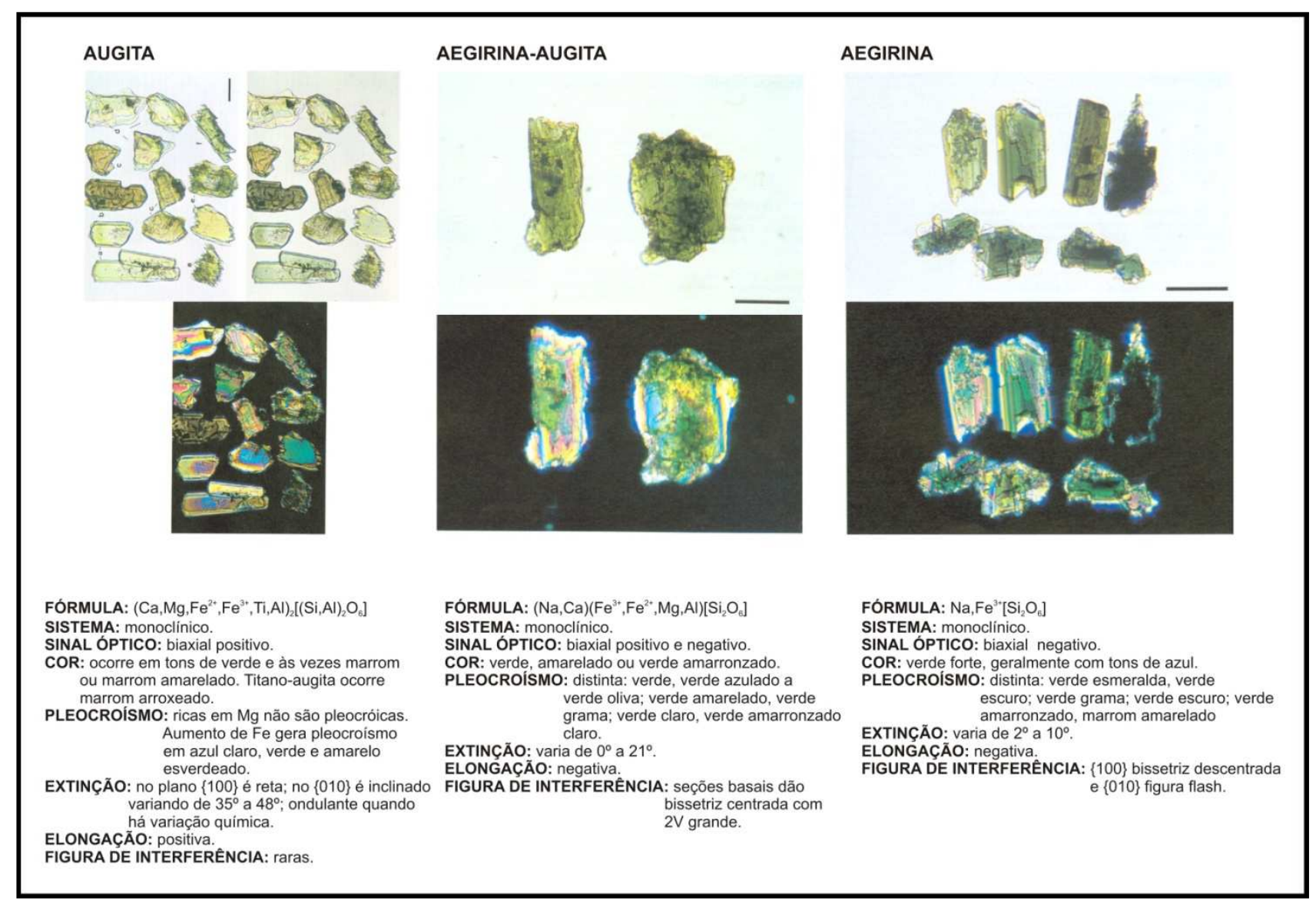

Figura III.2: características ópticas observáveis em microscópio petrográfico de três inossilicatos pertencentes ao Grupo dos Piroxênios (Mange e Maurer, 1992). 


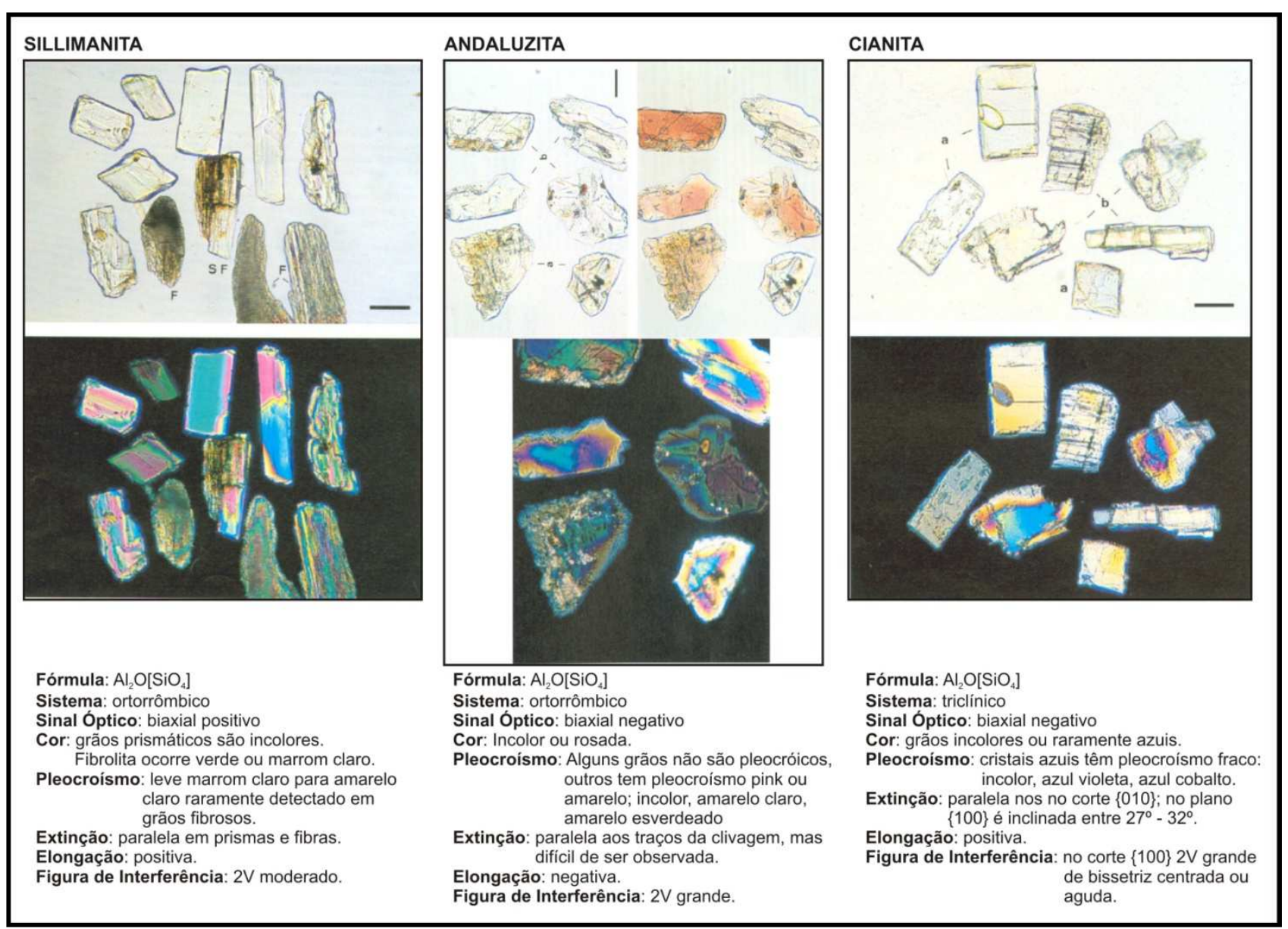

Figura III.3: características ópticas observáveis em microscópio petrográfico de três nesossilicatos, polimorfos de $\mathrm{Al}_{2} \mathrm{SiO}_{5}$ (Mange e Maurer, 1992).

\section{Índices minerais}

Apesar da sobreposição dos processos que controlam a distribuição dos minerais pesados nos sedimentos, as assembléias minerais guardam informações importantes sobre a proveniência da rocha ou sedimento estudado (Morton e Hallsworth, 1999). Quando minerais específicos destas assembléias são aplicados em índices específicos pré-estabelecidos, como HMA (Heavy Mineral Assemblages) convencional e variante, fornecem informações cruciais para a proveniência do sedimento (Morton e Hallsworth, 1999).

O HMA convencional utiliza todos os minerais pesados encontrados na rocha, aplicando razões minerais que consideram características hidrodinâmicas e de estabilidade frente ao soterramento diagenético (tabela III.3 e figura III.4), que são para Morton e Hallsworth (1999) os principais mecanismos que determinam a composição de minerais pesados em sedimentos. Para aplicação deste método os minerais escolhidos devem ser 
estáveis nas condições diagenéticas de estudo e devem ser de tamanho e densidade iguais, pois estes são os controladores do comportamento hidrodinâmico.

ÍNDICE

\begin{tabular}{|c|c|}
\hline Apatita-turmalina (ATi) & $100 \times$ contagem de apatita / (total apatita + turmalina) \\
\hline Granada-zircão (GZi) & 100 x contagem de granada / (total granada + zircão) \\
\hline Grupo $\mathrm{TiO}_{2}$-zircão (RZi) & 100 x contagem grupo $\mathrm{TiO}_{2} /$ (total grupo $\mathrm{TiO}_{2}+$ zircão) \\
\hline Rutilo-zircão (RuZi) & $100 \times$ contagem rutilo / (total rutilo + zircão) \\
\hline Monazita-zircão (MZi) & 100 x contagem monazita / (total monazita + zircão) \\
\hline $\begin{array}{l}\text { Cromo espinélio-zircão } \\
\text { (CZi) }\end{array}$ & $\begin{array}{l}100 \text { x contagem cromo espinélio / (total cromo espinélio + } \\
\text { zircão) }\end{array}$ \\
\hline
\end{tabular}

Tabela III.3: razões minerais propostas por Morton e Hallsworth (1994) aplicadas em estudos de HMA convencional.

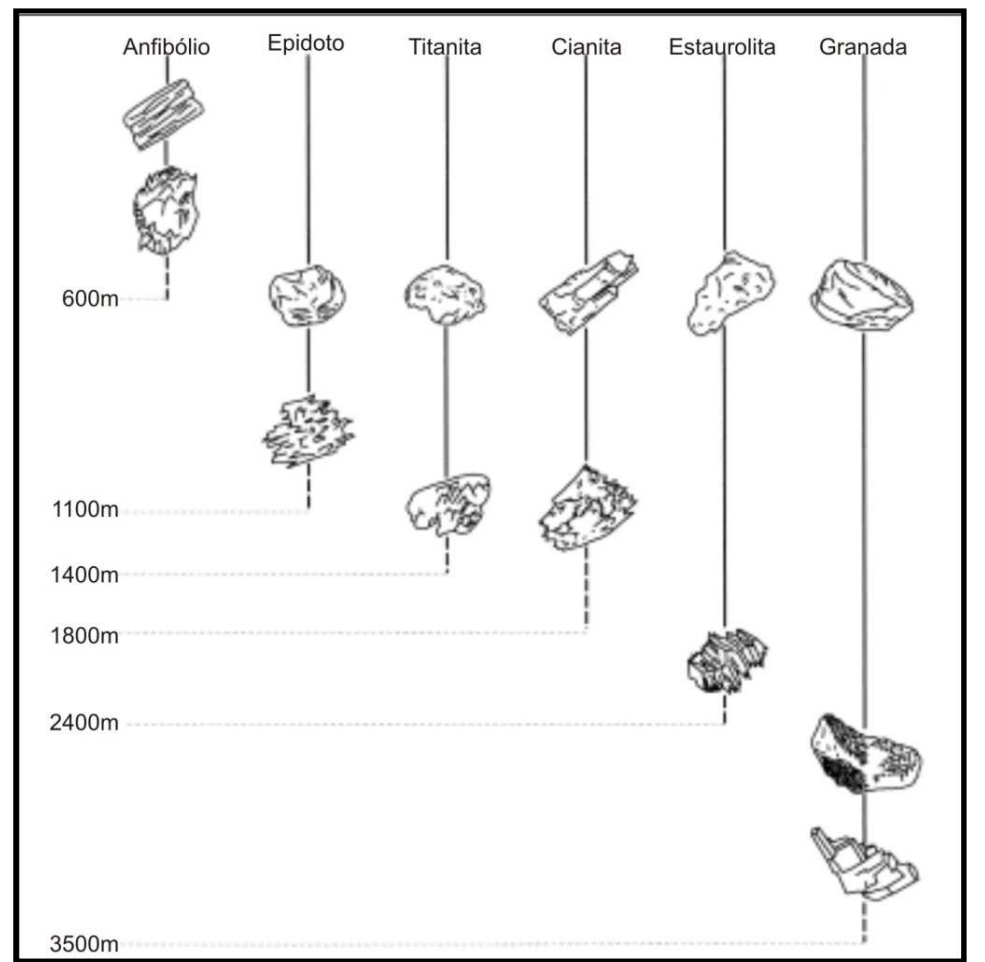

Figura III.4: texturas de dissolução em minerais estáveis e moderadamente estáveis do Mar Norte central publicadas por Morton (1984) e extraídas e traduzidas de Morton e Hallsworth (1999). As texturas são causadas pela dissolução provocada pelo soterramento diagenético. Observar a diminuição da diversidade mineral com o aumento da profundidade.

Por outro lado, o HMA variante se concentra nas características de cada mineral individualmente. Tradicionalmente, a diferenciação de proveniência utilizando este método se 
concentra em cor (ex.: turmalina), hábito (ex.: feições de arredondamento), zoneamento químico (ex.: quantidade de Ca na granada controla sua estabilidade em profundidade) e química isotópica (datações em zircão e monazita).

Ambos os métodos são importantes e o ideal é trabalhar com os dois combinados. Morton et al., (1999) sugere que o primeiro passo para um trabalho confiável é a caracterização, diferenciação e mapeamento dos tipos de areia usando o HMA convencional, que dá informações importantes sobre natureza e localização da área-fonte. Após esta etapa seleciona-se um ou mais minerais para fazer comparações mineralógicas diretas através do HMA variante para obter informações detalhadas sobre a litologia, com a provável determinação da área-fonte. Associada a estes mecanismos, a aquisição de dados isotópicos é complementar, pois estes fornecem intervalos de idade da área-fonte.

\section{III.2.2. Geoquímica mineral}

A geoquímica de grãos, além de diferenciar os vários tipos de minerais de um mesmo grupo, ou até identificar minerais de propriedades ópticas semelhantes, ajuda a contextualizar o sedimento em um ambiente tectônico provável, caracterizando a assinatura geoquímica da área-fonte e estabelecendo o intervalo, ou intervalos, no caso de mais de uma rocha-fonte, de idade no qual a mesma foi gerada.

A geoquímica de grãos minerais é realizada por análises composicionais quantitativas em microssonda eletrônica ou por determinações de sistemas isotópicos em espectrômetros de massa (ex.: LA-ICP MS, LA-MC-ICP MS) e microssonda iônica de alta resolução (SHRIMP).

A composição química detalhada de um mineral obtida em microssonda eletrônica é uma ferramenta consistente utilizada para identificar a rocha-fonte do sedimento e seu respectivo contexto tectônico. A predominância de minerais detríticos tipicamente metamórficos, como polimorfos de $\mathrm{Al}_{2} \mathrm{SiO}_{5}$, estaurolita, serpentina, hiperstênio entre outros, indica que rochas de origem metamórfica seriam a área-fonte principal, e uma análise mais detalhadas permite muitas vezes identificar o grau metamórfico em que esta rocha se formou. Por outro lado, minerais encontrados preferencialmente em rochas ígneas podem indicar, além do tipo de rocha o ambiente tectônico em que esta se formou, principalmente se estes minerais pertencem ao grupo dos piroxênios ou dos anfibólios, pois a composição química dos minerais pertencentes a estes grupos tem relação com o tipo de magmatismo que os gerou, e 
consequentemente, indicam suas fontes e o ambiente tectônico em que foi formado (Barros et al., 2005).

Minerais pesados ultraestáveis e estáveis (tabela III.1) como zircão, monazita e rutilo, apesar de serem encontrados em diversos tipos de rocha, são muito utilizados em datações absolutas (zircão e monazita) para a identificação direta da área-fonte pelo intervalo de idade obtido, e em geoquímica de elementos traço (rutilo e zircão) para identificação de assinaturas geoquímicas específicas para cada ambiente em que o mineral é formado (Belousuova et al, 2001; Zack et al., 2004).

Neste trabalho serão detalhados apenas as características químicas de zircão, rutilo e dos minerais do grupo do piroxênio.

\section{Análise química de minerais do grupo do piroxênio}

O uso de piroxênios como indicador de proveniência é limitado pela sua instabilidade em ambientes de temperatura baixa, onde é corroído e dissolvido por fluidos intersticiais, sendo raro em arenitos porosos (Morton, 1984). Porém, em arenitos de ambiente eólico ou em arenitos não-porosos chega a ser o mineral predominante da assembléia..

Barros et al. (2005) compilaram dados da literatura e utilizando o diagrama ternário de Morimoto et al. (1998) e o diagrama binário Nisbet e Pearce (1977) demonstraram que a composição química de piroxênios ajuda a identificar a rocha, ígnea ou metamórfica, que serviu de proveniência para o sedimento (figura III.5) e até mesmo o ambiente tectônico vigente durante a formação da mesma (figura III.6).

Geoquímica de cristais de rutilo

O rutilo é, junto com zircão, turmalina e anatásio, considerado um mineral ultraestável (tabela III.1) devido à sua resistência física e química frente às ações do intemperismo e da diagênese (Pettijon et al., 1975). Como resultado disso, contém informações da sua fonte primária, mesmo em sedimentos extremamente maturos e após soterramento em profundidades consideráveis (Zack et al., 2004b).

Enquanto zircão geralmente sobrevive ao ciclo das rochas de sedimentação até metamorfismo de alto grau e até mesmo a processos magmáticos, a quebra do rutilo ocorre no início da fácies xisto verde e é novamente formado em fácies de anfibolito superior. Portanto, quando presente na rocha sedimentar, indica características do pico metamórfico sofrido pela rocha fonte. 


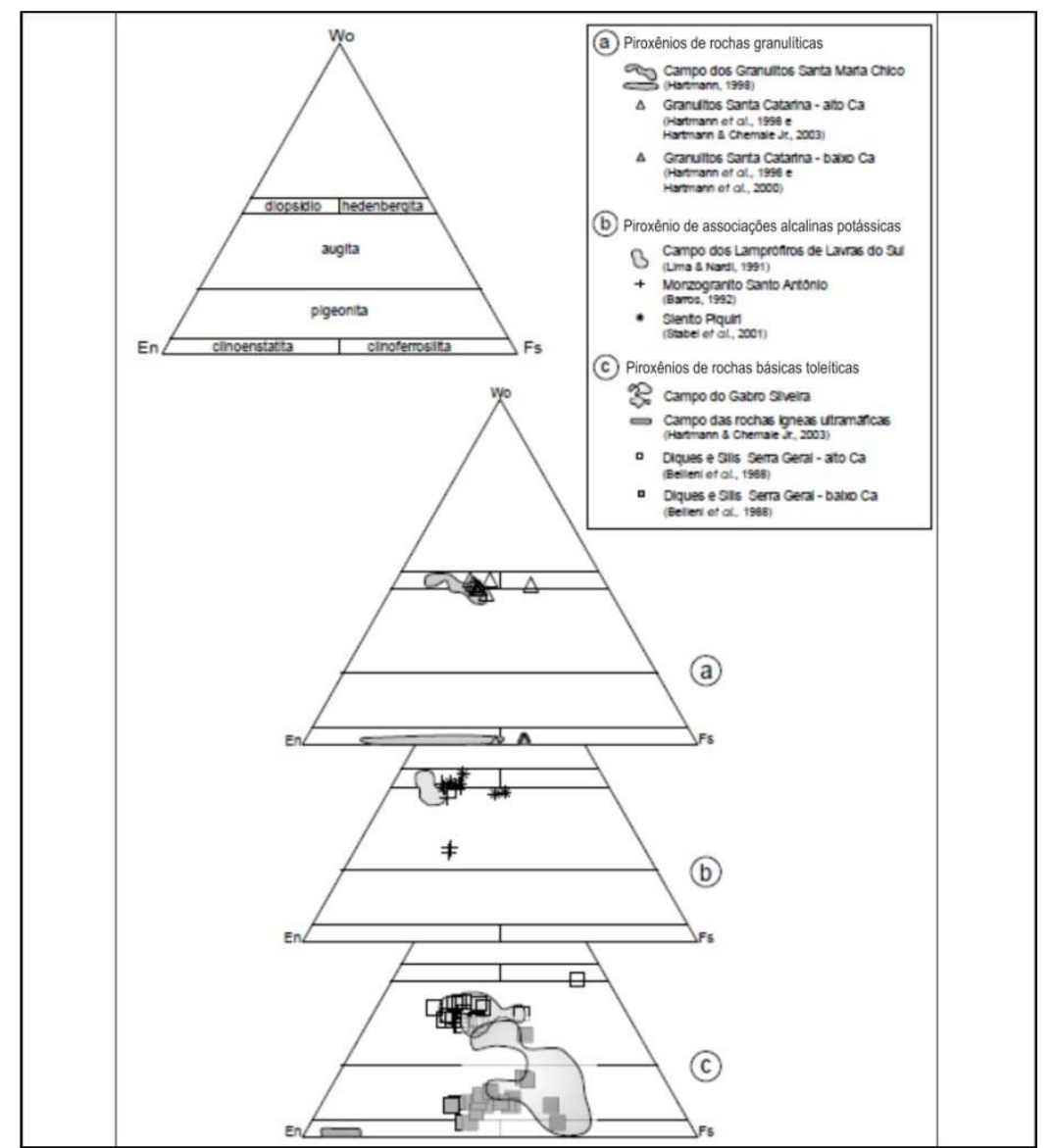

Figura III.5: Diagrama de classificação dos minerais pertencentes ao grupo dos piroxênios de rochas ígneas de diferentes ambientes tectônicos, extraído de Barros et al. (2005). Wo - wollastonita; En - enstatita; Fs ferrosilita (Diagrama: Morimoto et al., 1988; Dados plotados: Barros et al., 2005).

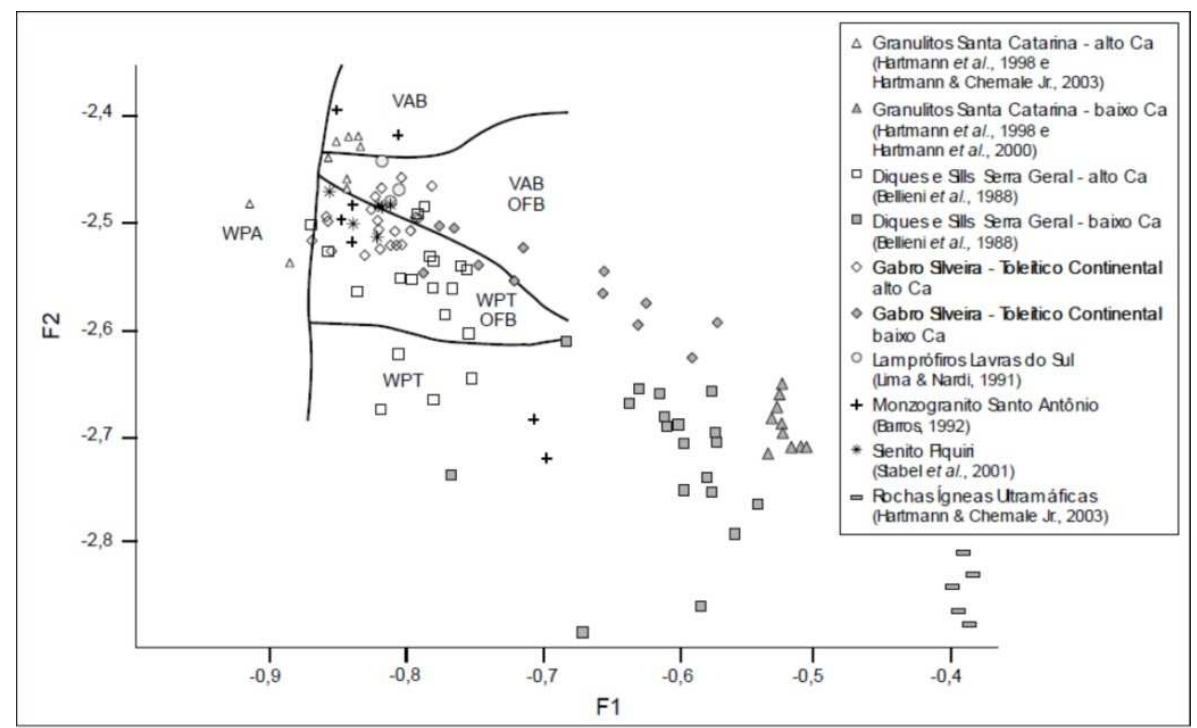

Figura III.6: diagrama de classificação de minerais do grupo do piroxênio a partir de suas concentrações de óxidos de $\mathrm{Si}$, Ti, Al, Fe, Mn, Mg, Ca e Na, extraído Barros et al. (2005). F1 = - $\left(0,012 \times \mathrm{SiO}_{2}\right)-\left(0,0807 \times \mathrm{TiO}_{2}\right)$ $\left.+0,0026 \times \mathrm{Al}_{2} \mathrm{O}_{3}\right)-\left(0,0012 \times \mathrm{FeO}^{*}\right)-(0,0026 \times \mathrm{MnO})+(0,0087 \times \mathrm{MgO})-(0,0128 \times \mathrm{CaO})-\left(0,0419 \times \mathrm{Na}_{2} \mathrm{O}\right) ;$ $\mathrm{F} 2=-\left(0,0469 \times \mathrm{SiO}_{2}\right)-\left(0,0818 \times \mathrm{TiO}_{2}\right)-\left(0,0212 \times \mathrm{Al}_{2} \mathrm{O}_{3}\right)-(0,0041 \times \mathrm{FeO} *)-(0,1435 \times \mathrm{MnO})-(0,0029 \times$ $\mathrm{MgO})+(0,0085 \times \mathrm{CaO})+\left(0,016 \times \mathrm{Na}_{2} \mathrm{O}\right)$; OFB: basalto de fundo oceânico; VAB: basaltos de arco vulcânico; WPT: basalto toleítico intraplaca; WPA: basalto alcalino intraplaca. (Diagrama: Nisbet \& Pearce, 1977; Dados plotados: Barros et al., 2005). 
Através da observação da química de elementos traço de cristais de rutilo analisados em microssonda eletrônica, Zack et al. (2004b) identificaram uma relação entre as concentrações de $\mathrm{Nb}$ e $\mathrm{Cr}$ em rutilo de rochas metabásicas e rochas metapelíticas. A partir da compilação dos dados é evidente que metacumulatos são caracterizados por rutilo com alto teor de $\mathrm{Cr}$, enquanto outras rochas metamáficas contêm rutilo com baixo $\mathrm{Cr}$ e $\mathrm{Nb}$ e metapelitos contêm rutilo com baixo $\mathrm{Cr}$ e alto $\mathrm{Nb}$ (figura III.7).

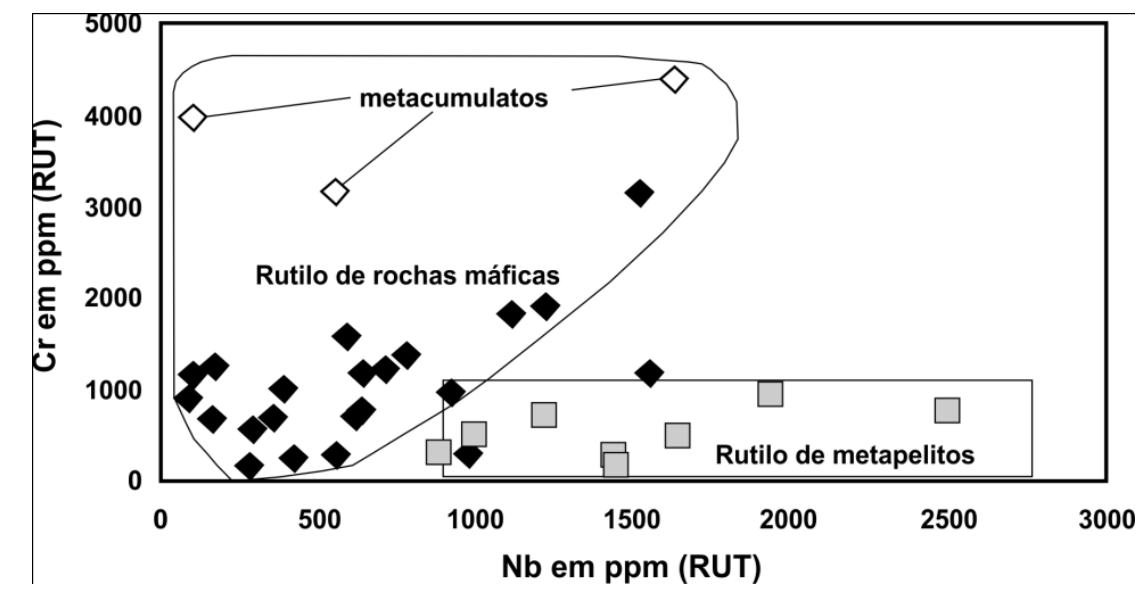

Figura III.7: diagrama de $\mathrm{Nb}$ ppm vs. Cr ppm com os campos de composição de rutilo de rochas máficas, rochas metacumuláticas e rochas metapelíticas (Zack et al., 2004b).

Associado a esta relação, o geotermômetro zircônio em rutilo (Tomkins et al., 2007; Zack et al., 2004a; Watson et al, 2006), que utiliza a medida de Zr em rutilo detrítico, pode ser usado para estimar a temperatura mínima experimentada pela rocha fonte, se for possível identificar que havia zircão e quartzo como fases em excesso. Como estas fases estão sempre presentes em metapelitos, se a rocha estudada tiver baixo $\mathrm{Cr}$ e alto $\mathrm{Nb}$, o geotermômetro pode ser utilizado (Zack et al., 2004b).

Geoquímica de cristais de zircão

O mineral zircão é resistente a ações do intemperismo, diagênese e metamorfismo, mantendo o sistema fechado em condições extremas de temperatura e pressão, preservando idades variadas, muitas vezes relacionadas a processos geológicos diferentes. Por causa destas características, este mineral é o mais utilizado na literatura, tanto para análises geoquímicas de elementos traço, quanto para análises de sistemas isotópicos. Além disso, a baixa velocidade de difusão intracristalina dos íons nos cristais de zircão favorece a preservação de sua 
composição química e isotópica durante a maior parte dos processos geológicos (Barros et al., 2005), e as principais características geoquímicas utilizadas na identificação de suas possíveis fontes, e do contexto tectônico das mesmas, são relacionadas aos teores de Zr, Hf, ETR, U, $\mathrm{Th}, \mathrm{Nb}$ e $\mathrm{Y}$.

Hoskin e Black (2000) analisaram elementos traço em cristais de zircão de rochas ígneas e metamórficas e identificaram diferenças marcantes com relação às concentrações de $\mathrm{Ce}, \mathrm{Th}, \mathrm{U}, \mathrm{Pb}$ e elementos terras raras leves (ETRL) (tabela III.4).

ZIRCÕES DE ORIGEM METAMÓRFICA

$$
\text { Razão Th/U }<0,1
$$

\section{ZIRCÕES DE ORIGEM ÍGNEA}

\section{Anomalias positivas de Ce;}

Forte empobrecimento de ETRL, Th e Pb.

Tabela III.4: assinaturas de elementos traço de zircões metamórficos e ígneos identificadas por Hoskin e Black (2000).

Pupin (2000, apud Barros et al., 2005) identificou diferenças marcantes na concentração de Hf e Y e na razão Zr/Hf de diferentes rochas ígneas geradas por processos geológicos diversos (Tabelas III.5 e III.6). Além disso, dados obtidos para $\mathrm{HfO}_{2}$ em zircões pegmatíticos foram sempre maiores que $2 \%$.

\begin{tabular}{ccc}
\hline & Hf & Y \\
\hline Granitóides Toleíticos & Baixo & Alto \\
Associações alcalinas sieno-granito & Baixo & Médio a baixo \\
Granitos de anatexia e migmatitos & Alto & Baixo \\
\hline
\end{tabular}

Tabela III.5: concentrações de Hf e Y em zircões de rochas ígneas formadas a partir de processos geológicos crustais distintos (Pupin, 2000, apud Barros et al., 2005).

No mesmo contexto, Belousova et al. (2002) consideram que zircões detríticos em rochas sedimentares podem ser atribuídos a litotipos específicos, o que acrescenta base para as informações comumente utilizadas em estudos de proveniência, como idade $\mathrm{U}-\mathrm{Pb}$ ou concentração de Hf. Neste trabalho os autores analisaram concentrações de elementos traço 
em zircões de diferentes tipos de rocha, obtendo campos específicos para cada litotipo (figura III.6). Para os autores, o reconhecimento de zircões relacionados a rochas mineralizadas pode contribuir para a exploração mineral, pois a identificação de zircões kimberlíticos, por exemplo, pode ser útil na exploração de diamantes.

\begin{tabular}{cccccc}
\hline & $\begin{array}{c}\text { Crosta } \\
\text { Continental }\end{array}$ & Mantélicos & Intraplaca & $\begin{array}{c}\text { Cálcio- } \\
\text { Alcalinos e } \\
\text { fusão parcial }\end{array}$ & $\begin{array}{c}\text { Sienitos } \\
\text { Nefeliníticos }\end{array}$ \\
\hline $\mathbf{Z r} / \mathbf{H f}$ & $36-45$ & $60-68$ & $>60$ & $<60$ & $73-135$ \\
\hline
\end{tabular}

Tabela III.6: razão Zr/Hf em rochas ígneas de diferentes ambientes tectônicos segundo Pupin (2000, apud Barros et al., 2005).
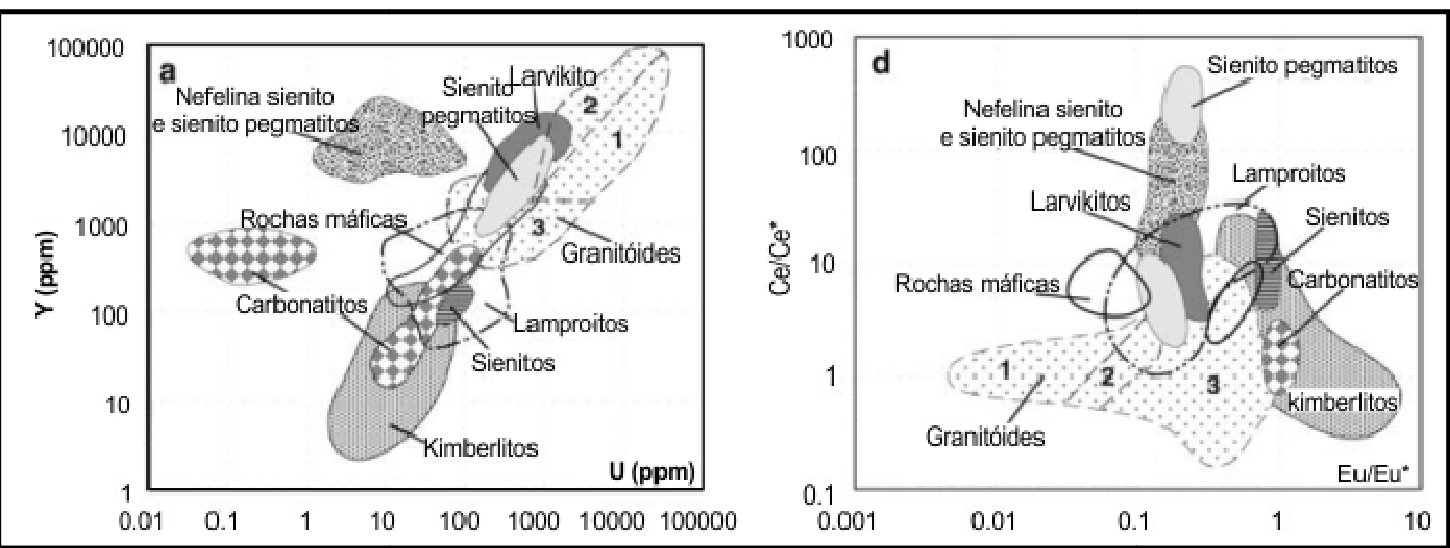

Figura III.8: gráficos de concentração $\mathrm{Y}(\mathrm{ppm}) v s$. U (ppm) e Ce/Ce* $v s$. Eu/Eu* para zircões de origem ígnea de diferentes litotipos extraídos e traduzidos de Belousova et al.(2002). Os números no campo dos granitóides significam: (1) aplitos e leucogranitos; (2) granitos; (3) granodioritos e tonalitos.

\section{III.2.3. Geoquímica de rochas sedimentares}

A geoquímica de rochas sedimentares, quando utilizada em estudos de proveniência sedimentar, deve considerar o comportamento de vários elementos químicos frente ao intemperismo, erosão, transporte, deposição e diagênese (Bhatia, 1985; McLennan et al., 1990). Estes processos geológicos secundários podem alterar a concentração de elementos químicos no sedimento, o que faz com que o mesmo possa não representar a composição química original da rocha-fonte (McLennan et al., 1990).

A utilização de elementos que têm sua concentração intensamente alterada por processos intempéricos (como $\mathrm{Na}, \mathrm{Ca}, \mathrm{K}$ e $\mathrm{Al}$ ) não é confiável em estudos de proveniência. Entretanto, estes podem ser aplicados em diagramas de classificação de arenitos ou em 
índices de alteração química para inferir as condições paleoclimáticas vigentes durante intemperismo, erosão da área-fonte do sedimento (Nesbitt e Young, 1982) e a distância relativa em relação à área-fonte.

Por outro lado, alguns elementos traços têm comportamento insolúvel e, por isso, são transportados quantitativamente para sedimentos terrígenos. A geoquímica destes elementos em rochas sedimentares tem sido amplamente utilizada em estudos que visam estimar a composição da crosta continental superior, conhecer os processos responsáveis por sua diferenciação e inferir ambientes tectônicos de deposição de sedimentos (Taylor e McLennan, 1985). Elementos Terras Raras, Th e Sc são os mais indicados nestes estudos, porque não tendem a se concentrar em minerais pesados, não sofrem influência de processos de fracionamento durante o transporte, como Zr, Hf, Nb e Sn (Bhatia, 1985; Bhatia e Crook, 1986; McLennan, 2001; McLennan e Taylor, 1991; McLennan et al., 1990; Taylor e McLennan, 1985, 1995). Outros elementos como Cr, Ni, Co e Ba, devem ser considerados de maneira cautelosa, pois têm suas concentrações fortemente afetadas, independente da intensidade, por processos como intemperismo, dissolução, transporte, deposição e diagênese (McLennan et al., 1990).

McLennan et al. (1990) demonstraram que a concentração de elementos maiores, elementos traço e composições isotópicas de $\mathrm{Nd}$ e $\mathrm{Sr}$ em turbiditos está relacionada ao ambiente tectônico em que o sedimento foi depositado. Os autores reconheceram diferenças significantes na composição de elementos traço de turbiditos modernos em relação aos turbiditos arqueanos, o que sugere que processos de criação e diferenciação da crosta continental se modificaram ao longo de sua evolução. A idade modelo $\mathrm{Nd}\left(\mathrm{T}_{\mathrm{DM}}{ }^{\mathrm{Nd}}\right)$ é variada para os turbiditos pós-Arqueanos o que sugere que a incorporação de componentes derivados do manto durante a reciclagem sedimentar é igualmente variável e relacionada com a dinâmica das placas tectônicas (McLennan et al., 1990). Além disso, a tectônica de placas influencia as características de proveniência e os processos sedimentares, pois afeta as assinaturas geoquímicas e isotópicas dos sedimentos (Bhatia, 1985; Bhatia e Crook, 1986; McLennan et al., 1990).

\section{III.2.3.1. Classificação química de arenitos}

A variedade composicional de matriz e fragmentos líticos e as diferentes abundâncias destes e de feldspatos detríticos nas rochas sedimentares arenosas, que definem os limites composicionais exatos para essas rochas, não podem ser obtidos por nenhum esquema de 
classificação química (Herron, 1988). Entretanto, alguns autores têm desenvolvido diagramas que visam às classificações químicas de arenitos considerando as relações entre composição elemental, mineralogia e tipo de rocha, baseados principalmente na presença frequente de feldspato potássico, muscovita e quartzo nestes sedimentos.

Pettijohn et al. (1972) sugere que a classificação seja baseada nas razões $\mathrm{Na}_{2} \mathrm{O} / \mathrm{K}_{2} \mathrm{O}$ e $\mathrm{SiO}_{2} / \mathrm{Al}_{2} \mathrm{O}_{3}$ (figura III.9), pois a primeira diferencia rochas ricas em plagioclásio albítico de rochas ricas em feldspato potássico e micas ricas em $\mathrm{K}$ e a segunda razão diferencia rochas maduras de imaturas (pobre em aluminosilicatos).

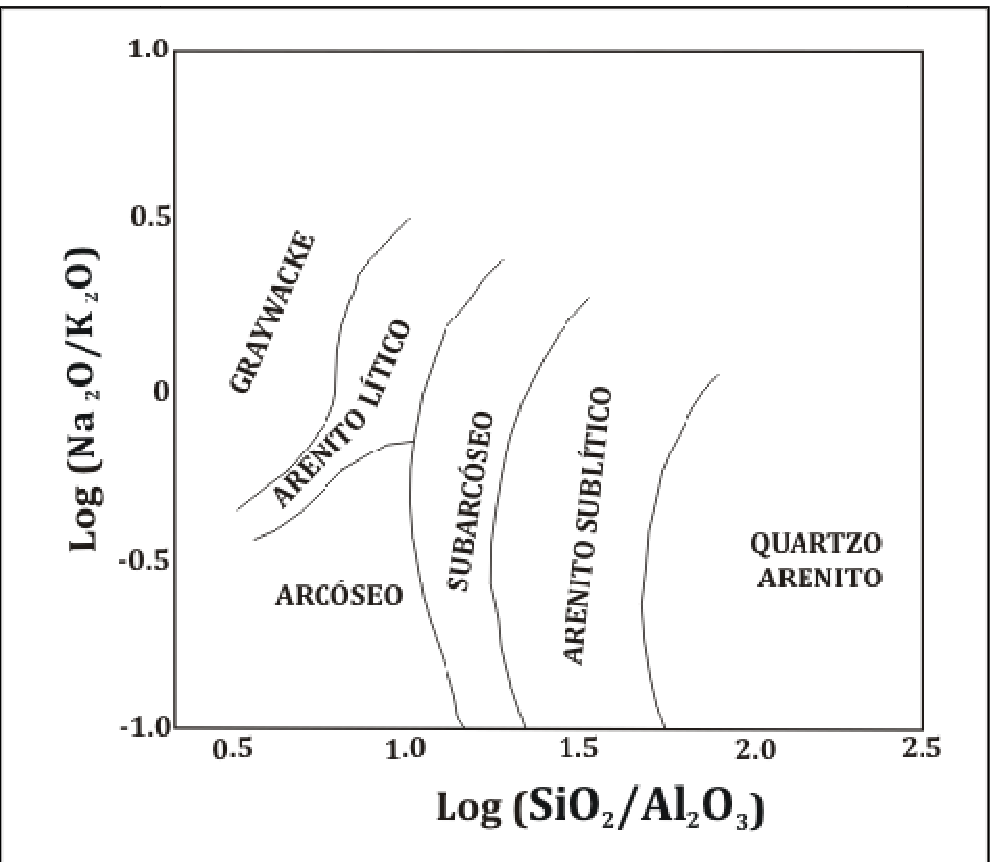

Figura III.9: gráfico $\mathrm{SiO}_{2} / \mathrm{Al}_{2} \mathrm{O}_{3}$ vs. $\mathrm{Na}_{2} \mathrm{O} / \mathrm{K}_{2} \mathrm{O}$ de classificação de arenitos segundo Pettijohn et al. (1972).

Por outro lado, Herron (1988) considera a utilização da razão $\mathrm{Na}_{2} \mathrm{O} / \mathrm{K}_{2} \mathrm{O}$ eficaz apenas na separação de graywackes e arcóseos, mas não é adequada para distinguir entre rochas ricas em fragmentos líticos daquelas mais ricas em feldspatos, rochas estas que compõe parte fundamental da maioria das classificações de arenitos. $\mathrm{O}$ autor sugere a substituição de $\mathrm{Na}_{2} \mathrm{O}$ por $\mathrm{Fe}_{2} \mathrm{O}_{3}$ (figura III.10), pois a razão $\mathrm{Fe}_{2} \mathrm{O}_{3} / \mathrm{K}_{2} \mathrm{O}$, por ser indicador de estabilidade mineral, distingue rochas ricas em feldspato potássico, muscovita e quartzo (minerais ricos em potássio, pobres em ferro e estáveis nas condições de baixa temperatura e pressão) daquelas ricas em fragmentos líticos, que são comumente ricos em minerais ferromagnesianos, e por isso menos estáveis às condições de temperatura e pressão da superfície terrestre. Outra diferença entre os esquemas de classificação de Pettijohn et al. (1972) e Herron (1988) é a 
ausência de pelitos no primeiro, que no segundo se diferenciam de rochas do tipo wacke (com matriz aluminosa que varia entre $15-75 \%$ ) pelas menores razões $\mathrm{SiO}_{2} / \mathrm{Al}_{2} \mathrm{O}_{3}$.

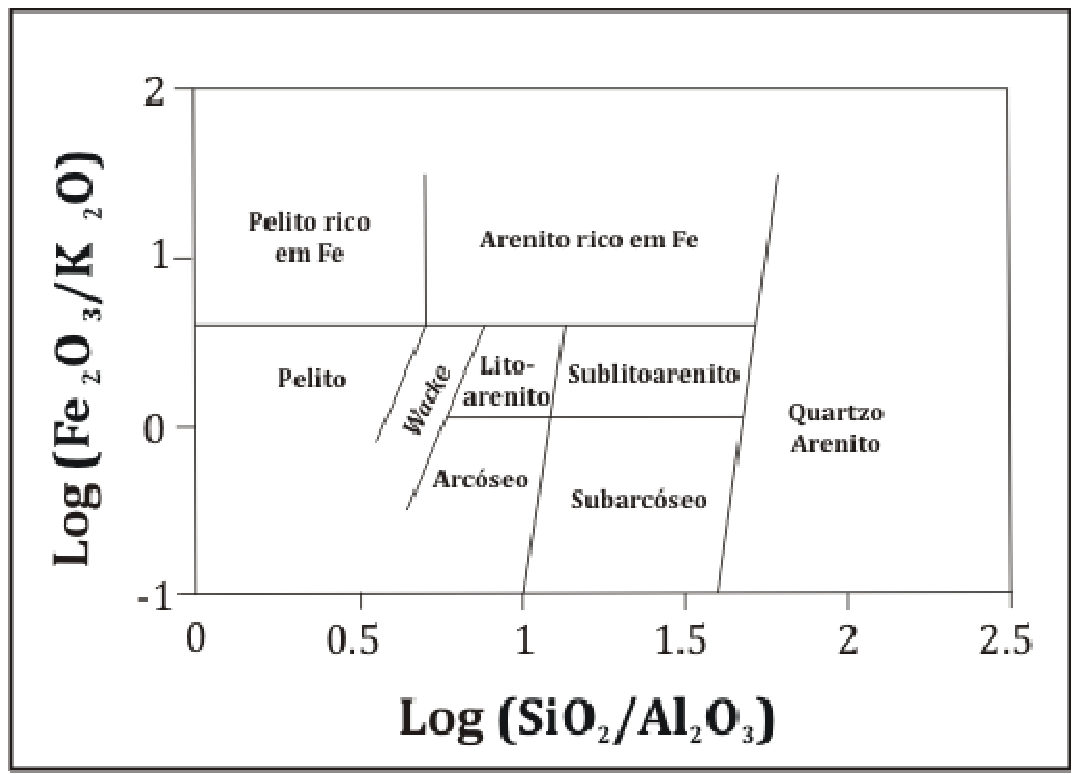

Figura III.10: gráfico $\mathrm{SiO}_{2} / \mathrm{Al}_{2} \mathrm{O}_{3}$ vs. $\mathrm{Fe}_{2} \mathrm{O}_{3} / \mathrm{K}_{2} \mathrm{O}$ de classificação de arenitos segundo Herron (1988).

\section{III.2.3.2. Elementos maiores e o intemperismo}

O intemperismo químico progressivo em rochas silicáticas causa perda de elementos, como $\mathrm{K}^{+}, \mathrm{Na}^{+}$e $\mathrm{Ca}^{2+}$, ocasionando a transformação de minerais primários em minerais secundários mais estáveis às condições da superfície terrestre. Esta reação resulta na formação de rochas sedimentares ricas em argilominerais, como caulinita e illita, e óxidos de ferro hidratado, como goethita.

Nesbitt e Young (1982) consideram que o processo dominante durante o intemperismo é a degradação de minerais do grupo do feldspato concomitante com a formação de argilominerais, pois os primeiros são os minerais reativos mais abundantes da crosta superior. Esta reação ocorre por meio de soluções agressivas que removem do feldspato os elementos $\mathrm{Ca}, \mathrm{Na}$ e $\mathrm{K}$, o que faz com que a proporção de $\mathrm{Al}$ em relação aos álcalis aumente, com o avanço do intemperismo. Partindo desta premissa, os autores desenvolveram um índice de alteração química (CIA - Chemical Index of Alteration) a partir das proporções moleculares dos óxidos de $\mathrm{Ca}$, $\mathrm{Na}, \mathrm{K}$ e Al:

$$
\text { CIA }(\mathrm{IAQ})=\left[\mathrm{Al} 2 \mathrm{O3} /\left(\mathrm{Al} 2 \mathrm{O3}+\mathrm{CaO}^{*}+\mathrm{Na} 2 \mathrm{O}+\mathrm{K} 2 \mathrm{O}\right)\right] \times 100
$$


Sendo o $\mathrm{CaO}^{*}$ a quantidade de $\mathrm{CaO}$ incorporada na porção silicática da rocha (correção feita para conteúdo de carbonato e apatita). Posteriormente, McLennan et al. (1990) inseriram a correção da quantidade de $\mathrm{Na}_{2} \mathrm{O}$ para possíveis alterações devido a interações com a água do mar (no caso de rochas coletadas em fundos oceânicos).

Este índice pode ser utilizado em rochas metassedimentares com confiança, pois os valores não sofrem mudanças significativas durante metamorfismo já que resultados similares foram obtidos em rochas que sofreram metamorfismo de baixo e alto grau na área analisada pelos autores.

Outro método de avaliação da intensidade de intemperismo químico e da proveniência de rochas sedimentares foi sugerido por McLennan et al. (1990). Neste trabalho os autores utilizaram gráficos ternários A-CN-K para representar as composições de elementos maiores em rochas coletadas de ambientes tectônicos ativos e passivos (figura III.11). Os autores compararam estas composições com a composição de minerais e de alguns tipos de rocha (extraídas de Nesbitt e Young, 1984, 1989), e identificaram que amostras de margens passivas sofrem maior intemperismo químico (plotam próximo às composições enriquecidas em $\mathrm{Al}_{2} \mathrm{O}_{3}$ ) do que amostras de ambientes vulcanicamente ativos (plotam próximo a composições enriquecidas em $\mathrm{CaO}$ e $\mathrm{Na}_{2} \mathrm{O}$ ). Esta diferença ocorre porque ambientes tectonicamente ativos estão associados a altas altitudes, onde predomina o intemperismo físico e o tempo necessário para que haja intemperismo químico significante não existe. Além disso, ambientes de margem passiva geralmente apresentam idades mais antigas do que os de margem ativa, sugerindo fonte de rochas mais antigas e sedimentos intensamente reciclados. Sucessivos ciclos de intemperismo que ocorrem nessa longa história contribuem para os maiores índices.

\section{III.2.3.3. Geoquímica de elementos traço}

Elementos traço, principalmente ETR, Th e Sc, são amplamente utilizados para determinação de proveniência, ambiente deposicional e contexto tectônico de rochas sedimentares e metassedimentares (Bhatia e Crook, 1986; McLennan et al., 1990, 1995; McLennan e Taylor, 1991) por causa das características químicas, inerentes a estes elementos, mencionadas no item III.3.3 deste capítulo.

As análises obtidas nestes estudos são utilizadas como base para estimativas da composição global da crosta continental superior (tabelas III.7 e III.8), da composição média de sedimentos clásticos (tabela III.9) e para estabelecer assinaturas geoquímicas de sedimentos clásticos depositados em diferentes ambientes tectônicos. Além disso, estas análises levam ao conhecimento sobre a 
proveniência destes sedimentos e, consequentemente, da evolução dos processos de formação da crosta desde o Arqueano até os dias atuais (McLennan et al., 1990).

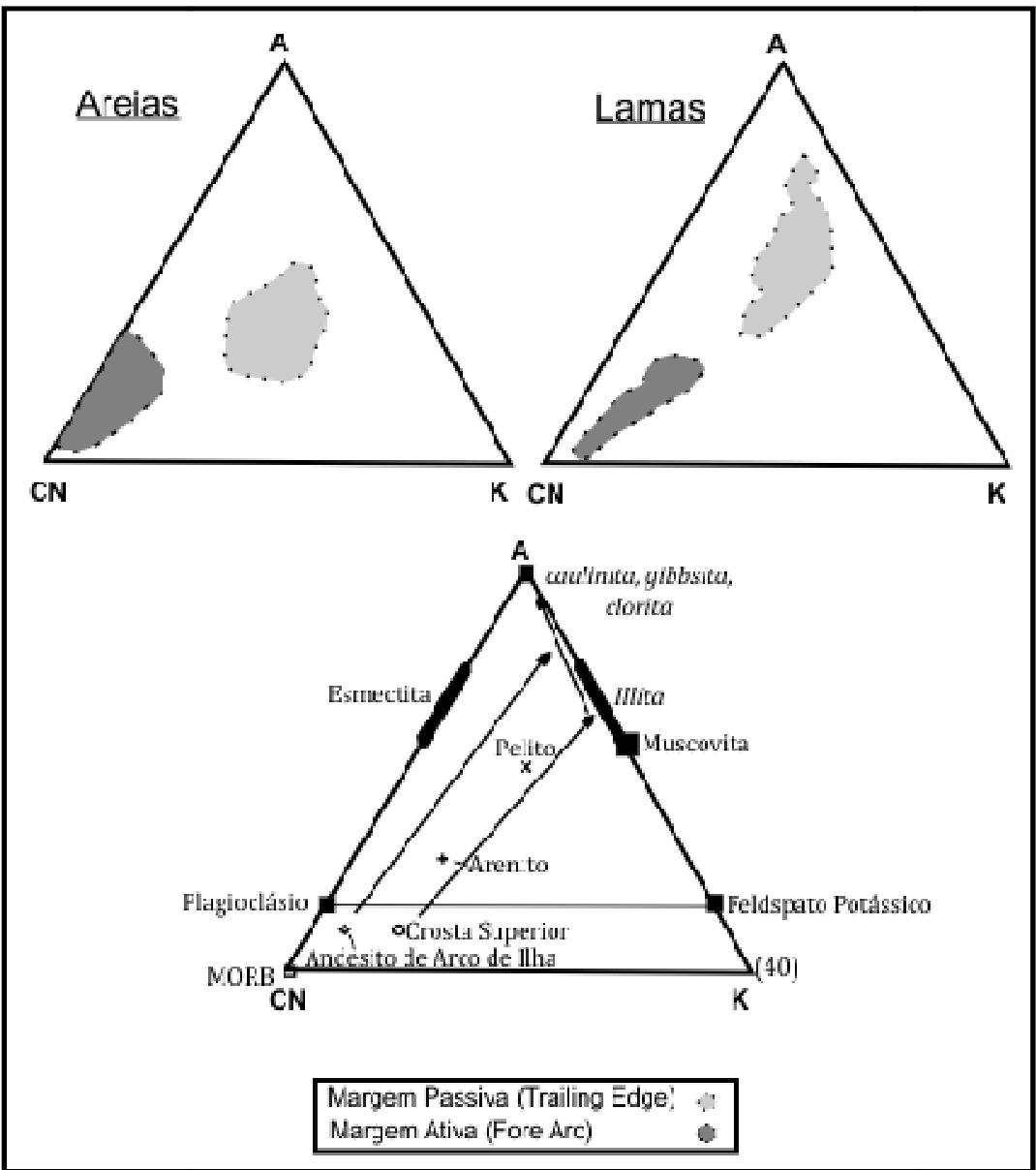

Figura III.11: diagramas ternários da fração molar de $\mathrm{Al}_{2} \mathrm{O}_{3}(\mathrm{~A})-\mathrm{CaO}+\mathrm{Na}_{2} \mathrm{O}$ em silicatos $(\mathrm{CN})-\mathrm{K}_{2} \mathrm{O}(\mathrm{K})$ extraído, modificado e traduzido de McLennan et al. (1990). A figura mostra os campos pelitos e arenitos analisados pelos autores de ambientes de margens passiva e ativa.

\begin{tabular}{|c|c|c|c|c|c|c|c|c|c|c|}
\hline & $\mathrm{SiO}_{2}$ & $\mathrm{TiO}_{2}$ & $\mathrm{Al}_{2} \mathbf{O}_{3}$ & $\mathrm{FeO}_{\mathrm{T}}$ & MnO & Mg0 & $\mathrm{CaO}$ & $\mathrm{Na}_{2} \mathrm{O}$ & $\mathbf{K}_{2} \mathbf{O}$ & $\mathbf{P}_{2} \mathbf{O}_{5}$ \\
\hline Condie (1993) & 67,0 & 0,56 & 15,14 & 4,76 & - & 2,45 & 3,64 & 3,55 & 2,76 & 0,12 \\
\hline $\begin{array}{c}\text { Taylor e McLennan } \\
\text { (1985) }\end{array}$ & 65,89 & 0,50 & 15,17 & 4,49 & 0,07 & 2,20 & 4,19 & 3,89 & 3,39 & 0,20 \\
\hline Rudnick e Gao (2003) & 66,62 & 0,64 & 15,40 & 5,04 & 0,10 & 2,48 & 3,59 & 3,27 & 2,80 & 0,15 \\
\hline
\end{tabular}

Tabela III.7: composição de elementos maiores da crosta continental superior segundo Condie (1993), Taylor e McLennan (1985) e Rudnick e Gao (2003). $\mathrm{FeO}_{\mathrm{T}}=\mathrm{Fe}$ total como FeO; Unidade: porcentagem em peso de óxido. 


\begin{tabular}{|c|c|c|c|}
\hline & Condie (1993) & Taylor e McLennan $(1985,1995)$ & Rudnick e Gao (2003) \\
\hline Sc & 13,4 & $13,6^{*}$ & 14 \\
\hline $\mathbf{V}$ & 86 & $107^{*}$ & 97 \\
\hline $\mathrm{Cr}$ & 112 & $85^{*}$ & 92 \\
\hline Co & 18 & $17^{*}$ & 17,3 \\
\hline $\mathrm{Ni}$ & 60 & $44^{*}$ & 47 \\
\hline $\mathrm{Cu}$ & - & 25 & 28 \\
\hline Zn & - & 71 & 67 \\
\hline $\mathbf{R b}$ & 83 & 112 & 84 \\
\hline $\mathrm{Sr}$ & 289 & 350 & 320 \\
\hline $\mathbf{Y}$ & 24 & 22 & 21 \\
\hline $\mathbf{Z r}$ & 160 & 190 & 193 \\
\hline $\mathrm{Nb}$ & 9,8 & $12^{*}$ & 12 \\
\hline Mo & - & 1,5 & 1,1 \\
\hline Sn & - & 5,5 & 2,1 \\
\hline Cs & - & $4,6^{*}$ & 4,9 \\
\hline Ba & 633 & 550 & 624 \\
\hline La & 28,4 & 30 & 31 \\
\hline $\mathrm{Ce}$ & 37,5 & 64 & 63 \\
\hline Pr & - & 7,1 & 7,1 \\
\hline Nd & 25,6 & 26 & 27 \\
\hline Sm & 4,59 & 4,5 & 4,7 \\
\hline Eu & 1,05 & 0,88 & 1,0 \\
\hline Gd & 4,21 & 3,8 & 4,0 \\
\hline $\mathbf{T b}$ & 0,66 & 0,64 & 0,7 \\
\hline Dy & - & 3,5 & 3,9 \\
\hline Ho & - & 0,8 & 0,83 \\
\hline $\mathbf{E r}$ & - & 2,3 & 2,3 \\
\hline Tm & - & 0,33 & 0,30 \\
\hline $\mathbf{Y b}$ & 1,91 & 2,2 & 2,0 \\
\hline Lu & 0,32 & 0,32 & 0,31 \\
\hline Hf & 4,3 & 5,8 & 5,3 \\
\hline $\mathbf{P b}$ & 17 & $17^{*}$ & 17 \\
\hline Th & 8,6 & 10,7 & 10,5 \\
\hline $\mathbf{U}$ & 2,2 & 2,8 & 2,7 \\
\hline
\end{tabular}

Tabela III.8: composição de alguns elementos traço da crosta continental superior segundo Condie (1993),

Taylor e McLennan (1985) e Rudnick e Gao (2003). Unidade: $\mu \mathrm{g} / \mathrm{g}$; (-): elemento não considerado pelo autor;

(*): valores corrigidos por McLennan (2001).

Rochas sedimentares de idade pós-arqueana se diferenciam dos sedimentos de idade arqueana principalmente pelos padrões de ETR (Bhatia, 1985; McLennan e Taylor, 1991; McLennan et al., 1990). Pelitos do pós-Arqueano apresentam enriquecimento em ETRL, padrão condrito-normalizado plano e constante de ETRP e empobrecimento significativo de Eu, com anomalia (Eu/Eu*) variável entre 0,60 e 0,70, com média de 0,65 (McLennan et al., 1990). Turbiditos do Fanerozóico, apesar de terem sido depositados em ambiente de margem 
passiva, têm a mesma assinatura. McLennan et al. (1990) reconheceram, com base em assinaturas geoquímicas, quatro áreas-fonte principais para os sedimentos pós-arqueanos:

(i) Crosta Continental Superior Antiga: crosta continental superior antiga formada por rochas ígneas e metamórficas que sofreram diferenciação intracrosta e/ou reciclagem sedimentar. Características diagnósticas: grande abundância de elementos LIL (large ion lithophile elements); altos valores das razões $\mathrm{Th} / \mathrm{Sc}, \mathrm{La} / \mathrm{Sm}$ e $\mathrm{Th} / \mathrm{U}$ (este provavelmente devido aos longos e/ou repetidos ciclos de intemperismo); anomalias negativas de Eu; e baixos valores de ${ }^{143} \mathrm{Nd} /{ }^{144} \mathrm{Nd}\left(\varepsilon_{\mathrm{Nd}}<-10\right)$.

(ii) Arco Jovem não diferenciado: material ígneo de arco jovem (vulcânico ou plutônico) que não sofreu diferenciação intracrosta significativa e por isso não apresenta anomalias negativas de Eu consideráveis. Características diagnósticas: abundâncias variáveis de elementos LIL; valores variáveis das razões Th/Sc e La/Sm; razão Th/U abaixo de 3,0 (derivados de fontes de manto empobrecido); razão ${ }^{143} \mathrm{Nd} /{ }^{144} \mathrm{Nd}$ relativamente alta $\left(\varepsilon_{\mathrm{Nd}}>+5\right)$ que o diferencia do componente anterior.

(iii) Arco Jovem Diferenciado: material ígneo de arco jovem que sofreu diferenciação intracrosta envolvendo cristalização fracionada de cristais de plagioclásio, representada por anomalias negativas de Eu. Anomalias negativas de $\mathrm{Eu}$ consideráveis $\left(\mathrm{Eu} / \mathrm{Eu}^{*}<1,0\right)$ diferenciam este componente do anterior.

(iv) Basalto do tipo MORB (Mid-Ocean Ridge Basalt): características diagnósticas: baixos teores de elementos LIL; baixas razões Th/Sc, La/Sm, Th/U e ${ }^{143} \mathrm{Nd} /{ }^{144} \mathrm{Nd}\left(\varepsilon_{\mathrm{Nd}}>+5\right)$. Diferencia-se dos componentes de arco jovem pelos altos teores de elementos traço ferromagnesianos (ex.: Cr, Ni) e pela razão $\mathrm{Ba}_{N} / \mathrm{La}_{\mathrm{N}}<1,0$.

Por outro lado, sedimentos arqueanos têm menor enriquecimento em ETRL e pouca ou nenhuma ocorrência de anomalias de Eu. Os padrões de ETR podem ser divididos em dois, sendo os inclinados referentes a sedimentos de primeiro ciclo derivados diretamente de terrenos TTG (tonalitos, tronddhjemitos e granodioritos) e os padrões planos derivados dos precursores do basalto e de sedimentos do primeiro ciclo (Taylor e McLennan, 1995). Além disso, apresentam menores razões de elementos incompatíveis contra elementos compatíveis (ex.: Th/Sc, La/Sc), sugerindo composição global mais máfica, e valores menores de anomalias negativas de $\mathrm{Eu}$, o que indica que processos de diferenciação crustal eram menos atuantes e menos importantes no controle da formação e da composição da crosta arqueana (McLennan e Taylor, 1991). 


\begin{tabular}{|c|c|c|c|c|c|c|c|}
\hline \multirow[b]{2}{*}{$\begin{array}{l}\text { Elementos } \\
\quad(p p m)\end{array}$} & \multicolumn{3}{|c|}{$\begin{array}{l}\text { SEDIMENTOS CLÁSTICOS } \\
\text { DE GRANULAÇÃO FINA }\end{array}$} & \multicolumn{4}{|c|}{ SEDIMENTOS CLÁSTICOS DE GRANULAÇÃO GROSSA } \\
\hline & NASC1 & PAAS $^{2}$ & Loess $^{3}$ & $\begin{array}{c}\text { Condie } \\
\text { sandstone }\end{array}$ & $\begin{array}{c}\text { Condie } \\
\text { graywacke }^{5}\end{array}$ & $\begin{array}{c}\text { PM } \\
\text { sand }^{7}\end{array}$ & $\begin{array}{c}\text { AM } \\
\text { sand8 }\end{array}$ \\
\hline Sc & 15 & 16 & 7,8 & 2,0 & 14 & 5,85 & 14,4 \\
\hline $\mathbf{T i}$ & 4200 & 6000 & 3720 & 1500 & 4320 & 2360 & 3800 \\
\hline $\mathbf{V}$ & - & 140 & 77 & 15 & 135 & 36 & 98 \\
\hline $\mathrm{Cr}$ & 127 & 100 & 56 & 30 & 75 & 41 & 43 \\
\hline Co & 26 & 20 & 10,6 & 2,5 & 18 & 6,5 & 13,5 \\
\hline $\mathbf{N i}$ & 58 & 60 & 20 & 8 & 38 & 19 & 16 \\
\hline $\mathbf{R b}$ & 125 & 160 & 73 & 25 & 90 & 61 & 67 \\
\hline $\mathbf{Z r}$ & 200 & 210 & 302 & 105 & 147 & 285 & 155 \\
\hline Nb & - & 18 & 12,7 & 4,0 & 10 & 7,71 & 6,73 \\
\hline Cs & 5,2 & 6,0 & 3,8 & - & - & 1,42 & 2,57 \\
\hline Ba & 636 & 650 & 458 & 150 & 625 & 403 & 441 \\
\hline La & 32 & 38,2 & 27,9 & 10,3 & 28 & 27,2 & 20,7 \\
\hline Hf & 6,3 & 5,0 & 8,9 & 3,1 & 3,8 & 9,68 & 4,73 \\
\hline Ta & 1,12 & 1,28 & 0,92 & 0,30 & 0,83 & - & - \\
\hline $\mathbf{P b}$ & - & 20 & 14,1 & 19 & 11 & 15,4 & 14,2 \\
\hline Th & 12,3 & 14,6 & 8,6 & 4,2 & 8,8 & 11 & 9,2 \\
\hline
\end{tabular}

Tabela III.9: Concentração de elementos traço de várias médias de sedimentos clásticos extraída de McLennan (2001). ${ }^{1}$ North American shale composite (Gromet et al., 1984); ${ }^{2}$ Post-Archean average Australian shale (Nace e Taylor, 1976; McLennan, 1981, 1989; Taylor e McLennan, 1985; Barth et al., 2000); ${ }^{3}$ Média da composição de loess baseada em oito médias regionais; ${ }^{4}$ Média de arenito cratônicos de idade fanerozóica (Condie, 1993); ${ }^{5}$ Média de graywacke do Fanerozóico (Condie, 1993); ${ }^{6}$ Média de bacias de Trailing Edge e Colisão Continental do pós-Arqueano (McLennan et al., 1990) e de arenitos do Paleozóico de margem passiva da Australia (Bhatia, 1981, 1985; Bhatia e Crook, 1986); ${ }^{7}$ Média de turbiditos arenosos de margem ativa derivados de bacias modernas de margem ativa (McLennan et al., 1993) e média de Arco de Ilha Oceânica, Arco Continental e Margens do tipo-Andino de idade paleozóica (Bhatia, 1985; Bhatia e Crook, 1986). 


\section{$\underline{\text { Anomalia de Eu }}$}

$\mathrm{O} \mathrm{Eu}$ ocorre na natureza como $\mathrm{Eu}^{2+}$ (condições redutoras) e $\mathrm{Eu}^{3+}$, característica única que o diferencia de outros ETR trivalentes. Anomalias negativas de Eu são interpretadas como herança de uma assinatura ígnea anterior caracterizada pela substituição de $\mathrm{Sr}^{2+}$ por $\mathrm{Eu}^{2+}$ em cristais de plagioclásio cálcico, fase residual ou formada por cristalização fracionada durante processos ígneos responsáveis pela diferenciação da crosta. Como o plagioclásio é estável em profundidades menores que $40 \mathrm{~km}$ estes processos são superficiais, e, por isso, anomalias de Eu são utilizadas para diferenciar áreas-fonte de origem mantélica daquelas de origem intracrosta (McLennan e Taylor, 1991).

Anomalias de Eu são calculadas a partir da equação:

$$
\mathbf{E u} / \mathbf{E u} \mathbf{u}^{*}=\mathbf{E} \mathbf{u}_{N} /\left[\left(\mathbf{S m}_{N}\right)\left(\mathbf{G d}_{N}\right)\right]^{1 / 2}
$$

Onde $\mathrm{N}$ subscrito indica que são valores condrito-normalizados e $\mathrm{Eu}^{*}$ representa o valor de Eu esperado para um padrão condrito-normalizado suave de ETR. Valores maiores que 1,0 são considerados positivos e valores menores que 1,0 negativos.

A presença de recorrente de anomalias negativas de Eu na maioria dos sedimentos pós-arqueanos indicam que processos intracrosta dominam a diferenciação da crosta continental, diferentemente do ocorrido durante o Arqueano, pois valores semelhantes são escassos em análises químicas de sedimentos desta idade (McLennan et al., 1990).

\section{$\underline{\text { Razão Th/Sc }}$}

O Th é um elemento fortemente incompatível durante processos ígneos de fusão e fracionamento, se concentrando tipicamente em rochas graníticas. Por outro lado, Sc tem comportamento compatível devido ao seu menor tamanho atômico em relação ao Th e outros ETR, e tende a entrar na estrutura cristalina de fases minerais estáveis a níveis profundos, como piroxênio, se concentrando em rochas ígneas básicas (McLennan e Taylor, 1991; Taylor e McLennan, 1995). Portanto, a razão Th/Sc, e La/Sc pelos mesmas características, é um indicador sensível de processos ígneos de diferenciação crustal (McLennan e Taylor, 1991).

McLennan et al. (1990) mostraram que turbiditos depositados em ambientes de margem passiva ou colisão continental a razão Th/Sc é relativamente constante e igual a 1,0, provavelmente pelo fato de que os sedimentos são oriundos de crosta continental estável e/ou da reciclagem de rochas sedimentares. Por outro lado, em ambientes de margem ativa os 
valores são variáveis e geralmente menores que 1,0, sugerindo que nestes ambientes a proveniência é mais variável e predominantemente máfica.

\section{$\underline{\text { Outros elementos }}$}

O fracionamento hidráulico durante a sedimentação concentra minerais pesados ultraestáveis e estáveis nas porções arenosas da bacia, pois estes apresentam maior densidade, o que impede seu carregamento para porções mais profundas e argilosas. Elementos como ETRL, ETRP, Zr e Hf tendem a se concentrar nestes minerais (ex.: monazita, apatita e zircão) e, portanto, a análises de suas concentrações pode diferenciar amostras de níveis distais ou proximais de uma bacia quando a relação elementos vs. minerais pesados vs. fracionamento hidráulico pode ser comprovada (McLennan et al., 1990).

Fralick e Kronberg (1997) sugerem que métodos de avaliação de imobilidade de elementos químicos podem auxiliar na determinação da proveniência de um sedimento. Estes métodos partem do princípio que elementos imóveis terão sua concentração aumentada ou diminuída à medida que elementos móveis são perdidos ou adquiridos pela rocha durante intemperismo, seleção, diagênese, metamorfismo e alterações hidrotermais. Os elementos imóveis que são concentrados em minerais selecionados por seu comportamento hidrodinâmico podem ser utilizados em razões que indicam a assinatura geoquímica da(s) área(s)-fonte, pois estes são transportados quantitativamente para o sedimento (McLennan et al., 1990). Além disso, o comportamento hidrodinâmico do elemento pode indicar se este se concentra nas porções arenosas ou argilosas do depósito sedimentar, diferenciando amostras depositadas em porções distantes ou próximas da área-fonte da bacia. 


\section{CAPÍTULO IV}

\section{ConteXto Geológico Regional}

O Cráton São Francisco, de idade no Arqueano-Paleoproterozóico, é circundado ao sul por um sistema de nappes com distintos campos de gradientes metamórficos e delimitados por contatos rúpteis de empurrão ou por rampas laterais, relacionado à colisão continental entre as placas São Francisco e Paranapanema, ocorrida durante o Neoproterozóico (Campos Neto, 2000).

Trouw et al. (1994) separaram este sistema de nappes em dois domínios, sendo um interpretado como uma continuidade meridional da Faixa Brasília, provavelmente resultante de uma colisão continental E-W, e outro interpretado como uma área de interferência das Faixas Brasília e Ribeira, resultante da superimposição de uma nova compressão com movimento de topo para NNW, seguida por transpressão destral relacionada a Faixa Ribeira.

Ribeiro et al. (1995) identificaram três domínios pré-cambrianos principais para este sistema:

(i) Domínio I (Autóctone): transição do Cráton São Francisco para a porção autóctone da zona orogênica. A deformação aumenta de norte para o interior da zona orogênica, localizada a sul;

(ii) Domínio II (Alóctone): sucessão de nappes e escamas empurradas, apresentando transporte tectônico para ENE. As superfícies marcadas como falhas de empurrão foram definidas a partir da observação de truncamentos ou repetição de unidades estratigráficas, pela presença de lentes do embasamento entre os metassedimentos e pulos metamórficos. Redobramentos, clivagens de crenulação e lineações dobradas permitiram a caracterização de duas fases de deformação, relacionadas à tectônica da Faixa Móvel Brasília;

(iii) Domínio III (Alóctone): zona de interferência mais intensa entre as faixas Brasília e Ribeira. Neste mesmo trabalho os autores caracterizam três eventos termo-tectônicos principais: (I) Transporte tectônico para E (600Ma), resultando em um conjunto de nappes e escamas tectônicas, com metamorfismo associado de pressão elevada (fácies granulito e rochas eclogíticas) correspondendo à colisão entre o Maciço Guaxupé e o proto-Cráton São Francisco; (II) Encurtamento crustal com transporte para NNW (570Ma), acompanhado de 
dobramento em escala regional e associado a um metamorfismo de pressão mais baixa com sillimanita, cordierita e corpos graníticos anatéticos; (III) Nova pressão E-W que gerou zonas de cisalhamento transpressionais subverticais, de orientação NE-SW com movimento destral. Os dois últimos episódios foram, por esses autores, relacionados à Faixa Móvel Ribeira.

Trouw et al. (2000) interpretam a área como uma megassequência deposicional e a nomeiam Megassequência Andrelândia, dividindo-a em 6 (seis) unidades distribuídas em 2 (duas) sequências deposicionais distintas (figura IV.1).

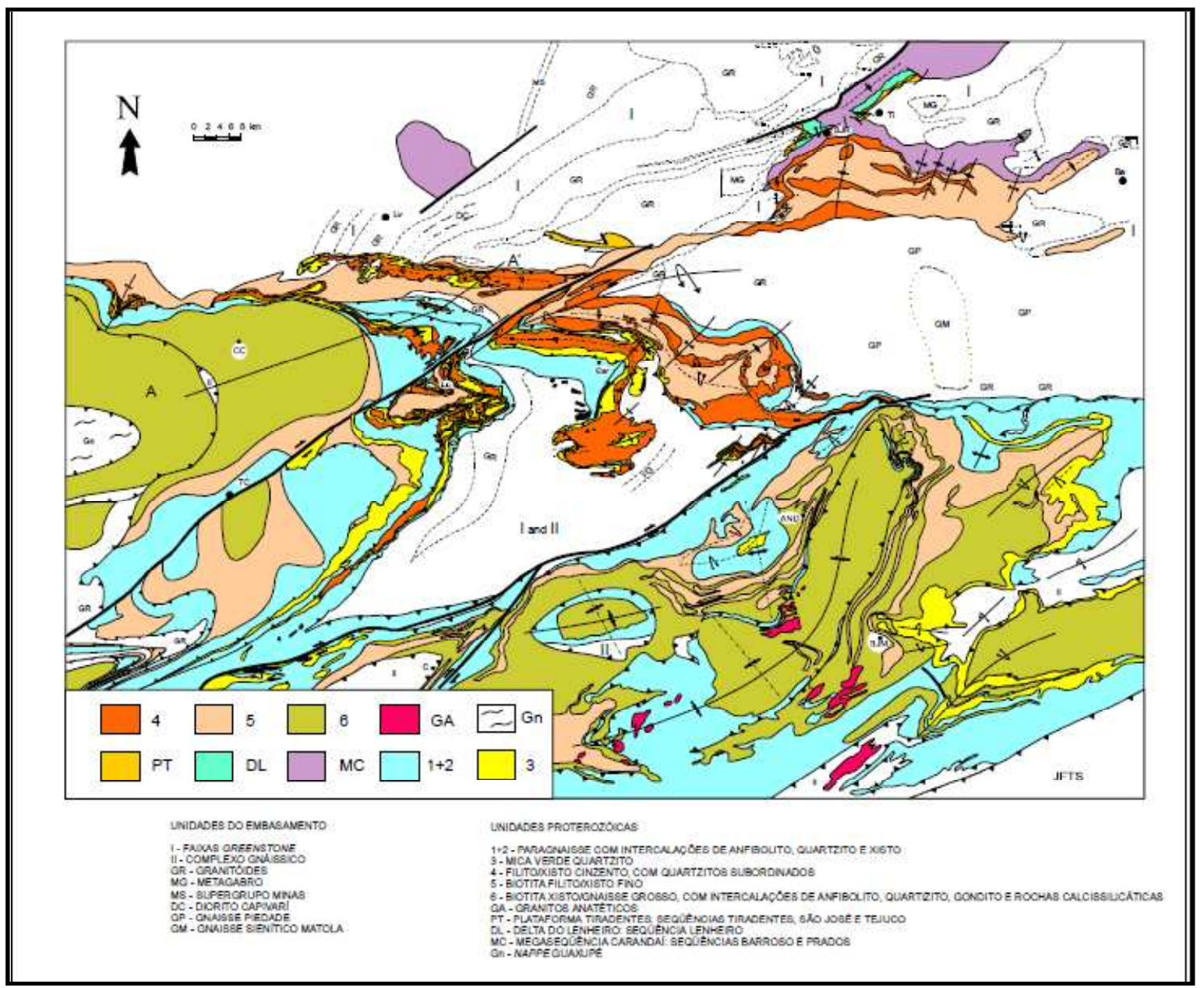

Figura IV.1: Mapa geológico regional com ênfase na Megassequência Andrelândia (Trouw et al., 2000, extraído de Paciullo et al., 2002).

Por outro lado, Campos Neto et al. (2004) apresenta a região como Orógeno Tocantins Meridional (Orógeno Brasilia Meridional - Campos Neto et al., 2007), interpretando as nappes como estruturas dúcteis sin-metamórficas, com removimentação rúptil pósmetamórfica e deslocamento mínimo de $300 \mathrm{~km}$. Dividiram o sistema orogênico, dos 
domínios internos (S-SW) aos externos (E-NE), em: Nappe Socorro-Guaxupé, Sistema de Nappes Andrelândia, Sistema de Nappes Carrancas e Nappe Lima Duarte (figura IV.2).

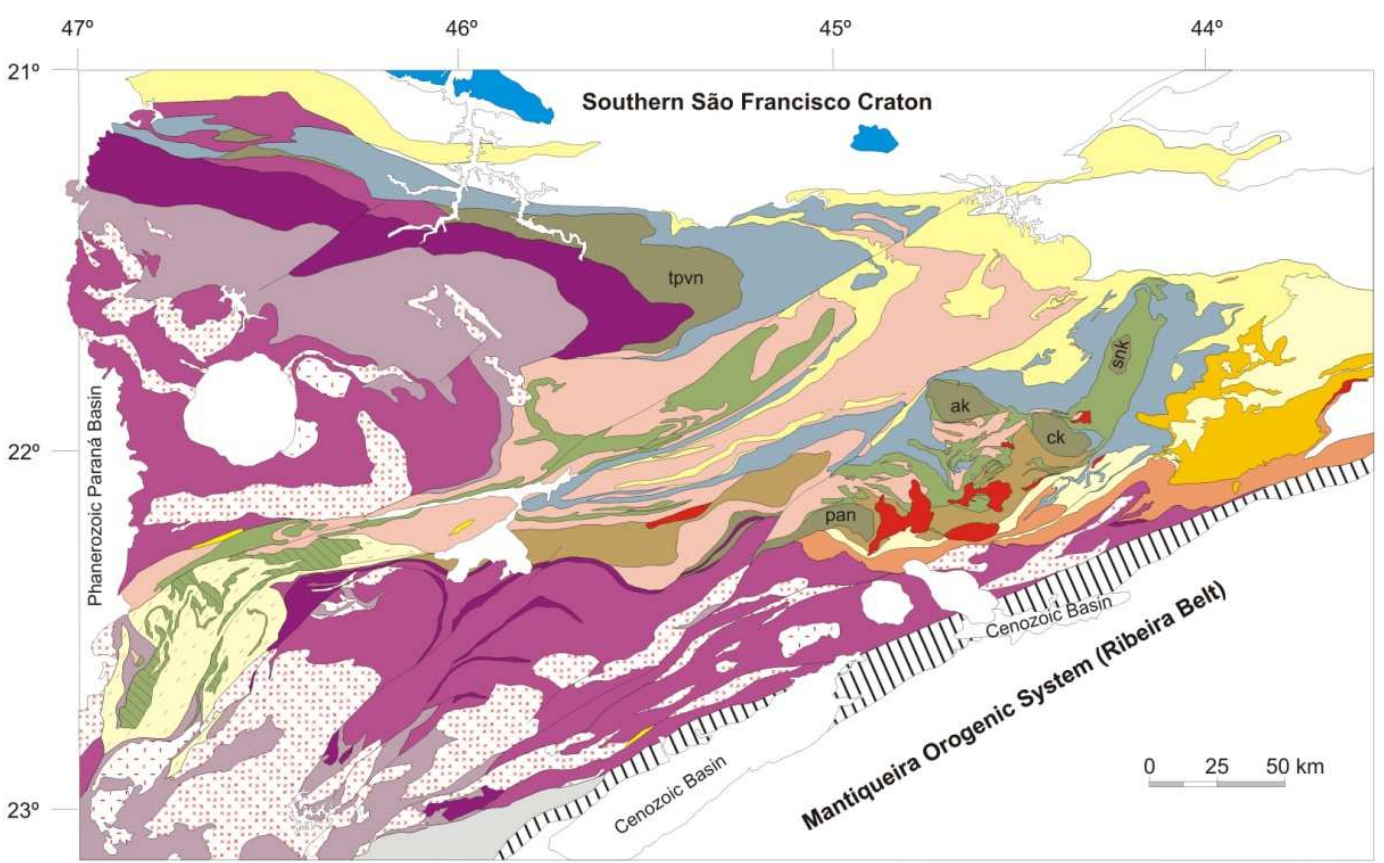

Ediacaran-Cambrian remnants of post-orogenic basin
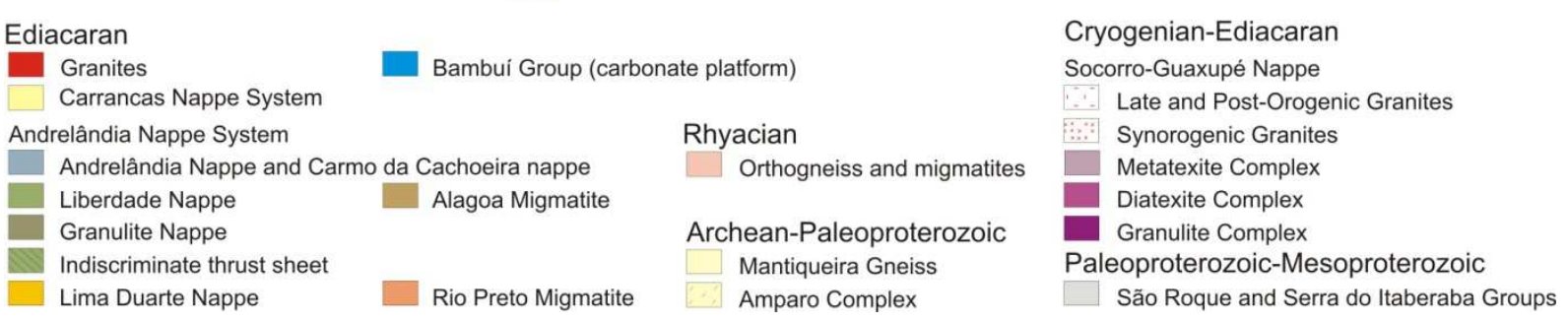

Figura IV.2: Mapa Tectônico do Orógeno Brasília Meridional (Campos Neto et al., 2011). Tpvn: Nappe Três Pontas-Varginha; pan: Nappe Pouso Alto; ak: Klippe Aiuruoca; ck: Klippe Carvalhos; snk: Klippe Serra da Natureza.

\section{IV.1. Unidades Mapeadas}

Desde Ebert (1956, apud Trouw et al., 1980) trabalhos de mapeamento geológico na região de Luminárias, Carrancas, Itumirim e Andrelândia, sudeste de Minas Gerais, vêm sendo efetuados, principalmente durante a década de 80 e nos anos 2000.

Apesar de todos estes trabalhos apresentarem similaridades quanto ao embasamento e quanto às características geológicas de campo, têm diferenças marcantes nas interpretações estratigráficas e tectônicas, principalmente quanto ao posicionamento do biotita xisto encontrado na base da Serra de Carrancas e na região de Luminárias (Formação Tiradentes e parte da Formação Carandaí de Ebert, 1956, apud Trouw et al., 1980; Unidade Biotita Xisto 
de Trouw et al., 1980; Fácies Sedimentar Autóctone do Grupo Carrancas de Ribeiro \& Heilbron, 1982; Unidade E do Grupo São João Del Rei de Trouw et al., 1983; base do Grupo Andrelândia em Trouw et al., 1986; Unidade A5 de Paciullo et al., 2000; e Unidade Na5 de Paciullo et al., 2002).

Os resultados dos principais trabalhos de mapeamento estão exemplificados nas Tabelas IV.1 a IV.9 (Anexo I).

\section{IV.2. Metamorfismo}

Campos Neto et al. (2004) considera as nappes estruturas dúcteis sin-metamórficas que sofreram removimentação rúptil pós-metamórfica. O padrão metamórfico regional é invertido (Teixeira, 2008; Motta, 2009), mas o sistema caracteriza-se por alóctonos com distintos campos de gradientes metamórficos, delimitados por contatos rúpteis de empurrão ou pelas rampas laterais (Campos Neto et al., 2007).

O grau metamórfico aumenta de norte para sul, da fácies xisto verde, na borda cratônica, até a anatexia, nas porções centrais da faixa móvel (Trouw et al., 1983 e 2000).

Paciullo et al. (2002) considera dois eventos metamórficos (descritos por Heilbron, 1984 e 1985), e os relaciona com a Faixa Brasilia $\left(M_{B R}\right)$ e com a Faixa Ribeira $\left(M_{R}\right)$. Segundo os autores, a característica marcante do $\mathrm{M}_{\mathrm{BR}}$ é a inversão metamórfica, com nappes em fácies granulito (Trouw et al., 1998) imbricadas sobre nappes em fácies anfibolito e xisto verde, além da presença de cianita e ausência de granitos. $O M_{R}$ caracterizaria-se pelo aparecimento de sillimanita, ausência de cianita e abundantes leucogranitos. Duas isógradas foram identificadas: entrada de sillimanita na porção central da faixa orogênica e a isógrada de saída da cianita (Trouw et al., 1983 e 2000b).

No entanto, para Campos Neto e Caby (1999, 2000), Santos et al. (2004), Campos Neto et al. (2004, 2010) e Motta (2009) a entrada na zona da sillimanita representa trajetórias de descompressão na evolução das nappes, dentro de uma única evolução orogênica.

\section{Sistema de Nappes Andrelândia (Campos Neto et al., 2007)}

O Sistema de nappes Andrelândia foi interpretado por Campos Neto et al. (2004) como um domínio continental subductado, evidenciado pelas nappes de alta pressão, estiradas e transportadas para ENE e NE. 
Nappe Pouso Alto e Klippen Aiuruoca, Carvalhos e Serra da Natureza

Rochas de alta temperatura e pressão que ocorrem nas nappes superiores do sistema. Consistem em rochas metapelíticas de fácies granulito, com bandamento composicional herdado de estratificação sedimentar e delineado por distintas proporções entre cianita e granada e entre plagioclásio e feldspato potássico. São correlacionáveis a Nappe Três PontasVarginha (Campos Neto e Caby, 2000) e atingiram pico metamórfico a temperatura de $900{ }^{\circ} \mathrm{C}$ e pressão de 15 kbar (Trouw et al., 1998; 2000 a, b). Condições de temperatura entre 850 e $900{ }^{\circ} \mathrm{C}$ para pressão de $12 \mathrm{kbar}$ foram obtidas para o pico metamórfico dos granulitos da Klippe Carvalhos (Campos Neto et al., 2010).

\section{Nappe Liberdade (Trouw et al., 2000 a)}

Seqüência metapelítica, com metapsamitos e gnaisses calciossilicáticos subordinados, metamorfisados em fácies anfibolito de alta pressão e contendo lascas de rochas metabásicas retro-eclogíticas, associadas à metaultramáficas. Migmatitos diatexíticos sin-cinemáticos estão presentes na retaguarda da nappe (Migmatitos Alagoa), e são cortados por plútons de muscovita-biotita granitos tardi-cinemáticos e por corpos tabulares de (granada)-turmalinamuscovita leucogranitos tardi a pós-cinemáticos (Campos Neto et al., 2004 e 2007).

Santos et al. (2004) calcularam condições metamórficas em torno de $770^{\circ} \mathrm{C}$ e $11 \mathrm{kbar}$ para rochas metapelíticas, enquanto que as rochas metabásicas retroeclogíticas atingiram condições báricas de 17 kbar para temperaturas de $680^{\circ} \mathrm{C}$ (Campos Neto e Caby, 1999; Trouw et al., $2000 \mathrm{a}, \mathrm{b})$.

Nappe Andrelândia (Trouw et al., 2000 a)

A Nappe Andrelândia possui um padrão metamórfico invertido, caracterizado por condições de fusão parcial e geração de leucossoma trondjemítico, no topo da estrutura, onde localmente ocorre feldspato potássico. Na base da nappe as rochas metapelíticas encontram-se na zona da estaurolita (Teixeira, 2008; Motta, 2009).

Cálculos de temperatura e pressão em metapelitos indicam condições de $660{ }^{\circ} \mathrm{C}$ e 11 kbar, com descompressão isotérmica passando por condições de $650{ }^{\circ} \mathrm{C}$ e 7,5 kbar e resfriamento isobárico posterior (Santos et al., 2004). Condições semelhante foram obtidas por (Motta, 2009). 
Sistema de Nappes Carrancas (Campos Neto et al., 2004) - Grupo Carrancas (Trouw et al., $\underline{1980)}$

Heilbron (1984 e 1985) considera duas gerações de paragêneses metamórficas, sendo a primeira a principal com características de pressão intermediária, e progressão de fácies xisto verde a anfibolito, produzindo paragêneses retrógradas no embasamento. A segunda geração tem características de fácies xisto verde e tem caráter tardio em relação às fases de deformação que atuaram na área.

Ainda neste trabalho, a autora identificou que a progressão do metamorfismo principal se dá desde fácies xisto verde até anfibolito médio, com paragêneses específicas da fácies xisto verde médio, da fácies xisto verde superior, da transição fácies xisto verde fácies anfibolito e da fácies anfibolito (tabela IV.10). Três isógradas foram traçadas: aparecimento de almandina, aparecimento de estaurolita e cianita nos xistos grafitosos, e o desaparecimento de cloritóide primário.

Quanto à segunda geração de paragêneses, a autora reconhece como resultante de um metamorfismo tardi- $\mathrm{D}_{3}$, sendo caracterizada por grandes porfiroblastos e agregados de cloritóide nos xistos (substitui cristais de almandina), pelo crescimento de placas de cristais de muscovita discordantes da estrutura geral observada nas lâminas delgadas e pelo aparecimento de porfiroblastos e/ou agregados de clorita sobre a xistosidade principal.

Silva (2010) obteve padrões metamórficos para os metapelitos da Klippe Carrancas (Trouw et al., 2000) com pico metamórfico progressivo de $10,0 \pm 1,7$ kbar e $577 \pm 8^{\circ} \mathrm{C}$ para a associação mineral estaurolita-granada-clorita-cloritóide-muscovita-quartzo e de 12,9 $\pm 1,0$ kbar e $608,5 \pm 19,5^{\circ} \mathrm{C}$ para a associação mineral cianita-estaurolita-granada-quartzo, com paragênese retrometamórfica estabilizada em 7,0 $\pm 2,2$ kbar e 541,5 $\pm 25,5^{\circ} \mathrm{C}$.

\section{IV.3. Análise Estrutural}

Trouw et al. (2000) divide a Megassequência Andrelândia (Paciullo et al., 2002) nos domínios autóctone e alóctone que na área de estudo desta monografia são representados por (figura IV.3):

- Domínio Autóctone: embasamento e sequências A1 a A5 da bacia Andrelândia;

- Domínio Alóctone: nappes Luminárias (unidades A1 a A5) e São Tomé (unidades A1 a A5) e Klippe Carrancas (unidades A3 e A4). 


\begin{tabular}{|c|c|}
\hline \multirow{3}{*}{$\begin{array}{l}\text { Xisto Verde } \\
\text { Médio }\end{array}$} & $\begin{array}{c}\text { Metapelitos dos grupos Carrancas e São João del Rei: mica branca + } \\
\text { quartzo + grafita + cloritóide } \pm \text { clorita } \pm \text { opacos } \pm \text { turmalina; mica branca + } \\
\text { quartzo + grafita + clorita } \pm \text { opacos } \pm \text { turmalina; mica branca + quartzo + } \\
\text { grafita } \pm \text { opacos } \pm \text { turmalina. }\end{array}$ \\
\hline & $\begin{array}{l}\text { Biotita xisto do Grupo São João del Rei: mica branca }+\mathrm{Bt} \pm \mathrm{Chl} \pm \mathrm{Qtz} \pm \mathrm{Pl} \pm \\
\text { opacos } \pm \text { almandina } \pm \text { carbono. }\end{array}$ \\
\hline & Quartzitos de Itutinga: mica branca $+\mathrm{Qtz}+$ opacos + turmalina $\pm \mathrm{Ky}$. \\
\hline & TRANSIÇÃO: ISÓGRADA DA GRANADA ALMANDINA \\
\hline \multirow{3}{*}{$\begin{array}{l}\text { Xisto Verde } \\
\text { Superior }\end{array}$} & $\begin{array}{l}\text { Grupo São João del Rei: mica branca }+ \text { Qtz + grafita + clorita + granada } \pm \\
\text { opacos } \pm \text { turmalina. }\end{array}$ \\
\hline & $\begin{array}{c}\text { Formação Campestre: } \text { mica branca }+\mathrm{Qtz}+\text { grafita }+\mathrm{Cld}+\mathrm{Grt}+\text { opacos } \pm \\
\text { turmalina. }\end{array}$ \\
\hline & Biotita Xisto: mica branca $+\mathrm{Qtz}+\mathrm{Bt}+\mathrm{Grt} \pm \mathrm{Chl} \pm$ opacos \pm turmalina. \\
\hline \multirow{2}{*}{$\begin{array}{c}\text { Transição Xisto } \\
\text { Verde - } \\
\text { Anfibolito }\end{array}$} & Marcada pela coexistência de cloritóide primário e estaurolita. \\
\hline & $\begin{array}{c}\text { Paragênese típica: mica branca }+ \text { Qtz }+ \text { grafita }+\mathrm{Cld}+\mathrm{Grt}+\mathrm{St} \pm \mathrm{Ky} \pm \text { opacos } \\
\pm \text { turmalina. }\end{array}$ \\
\hline \multicolumn{2}{|r|}{ TRANSIÇÃO: DESAPARECIMENTO DO CLORITÓIDE PRIMÁRIO } \\
\hline Anfibolito & Xistos grafitosos da Formação Campestre: granada + estaurolita \\
\hline
\end{tabular}

Tabela IV.10: principais paragêneses metamórficas dos grupos Carrancas e São João del Rei, segundo Heilbron (1985). Litotipos segundo Trouw et al., 1983

De maneira geral, foram estabelecidos três fases deformacionais $\left(D_{1}, D_{2}\right.$ e $\left.D_{3}\right)$, cada uma responsável por um grupo de estruturas que se superpõe, respectivamente, e que integram um só ciclo orogenético (Trouw et al., 1980, 1982 e 1983; Paciullo, 1983):

$\mathbf{D}_{1}$ : esta fase foi definida pela observação de algumas feições, como: foliação $S_{2} \mathrm{em}$ muitos lugares é uma foliação de crenulação; nos quartzitos as dobras $\mathrm{D}_{2}$ deformam 
uma clivagem anterior; escamas e/ou nappes de metassedimentos, empilhados e separados por embasamento quando se desdobram as dobras $\mathrm{D}_{2}$ e $\mathrm{D}_{3}$ (empurrões de placas relativamente rígidas de metassedimentos pré- $\mathrm{D}_{2}$ ). Esta fase foi responsável por uma clivagem regional, poucas dobras e grandes movimentos de empurrão que causaram uma distribuição regional dos metassedimentos em escamas e nappes (Trouw et al., 1983).

$\mathbf{D}_{2}$ : Fase responsável pela formação de uma clivagem e/ou xistosidade penetrativa $\left(\mathrm{S}_{2}\right)$ geralmente acompanhada por uma lineação mineral $\left(\mathrm{L}_{2}\right)$, além de dobras. Dentro do plano $\mathrm{S}_{2}$, e paralelo aos eixos de dobras $\mathrm{D}_{3}$, ocorre uma lineação mineral, $\mathrm{L}_{2}$, definida por conjuntos de cristais de quartzo orientados. Minerais metamórficos, como cianita ou muscovita, podem, quando são elongados, também contribuir a formação de $\mathrm{L}_{2}$.

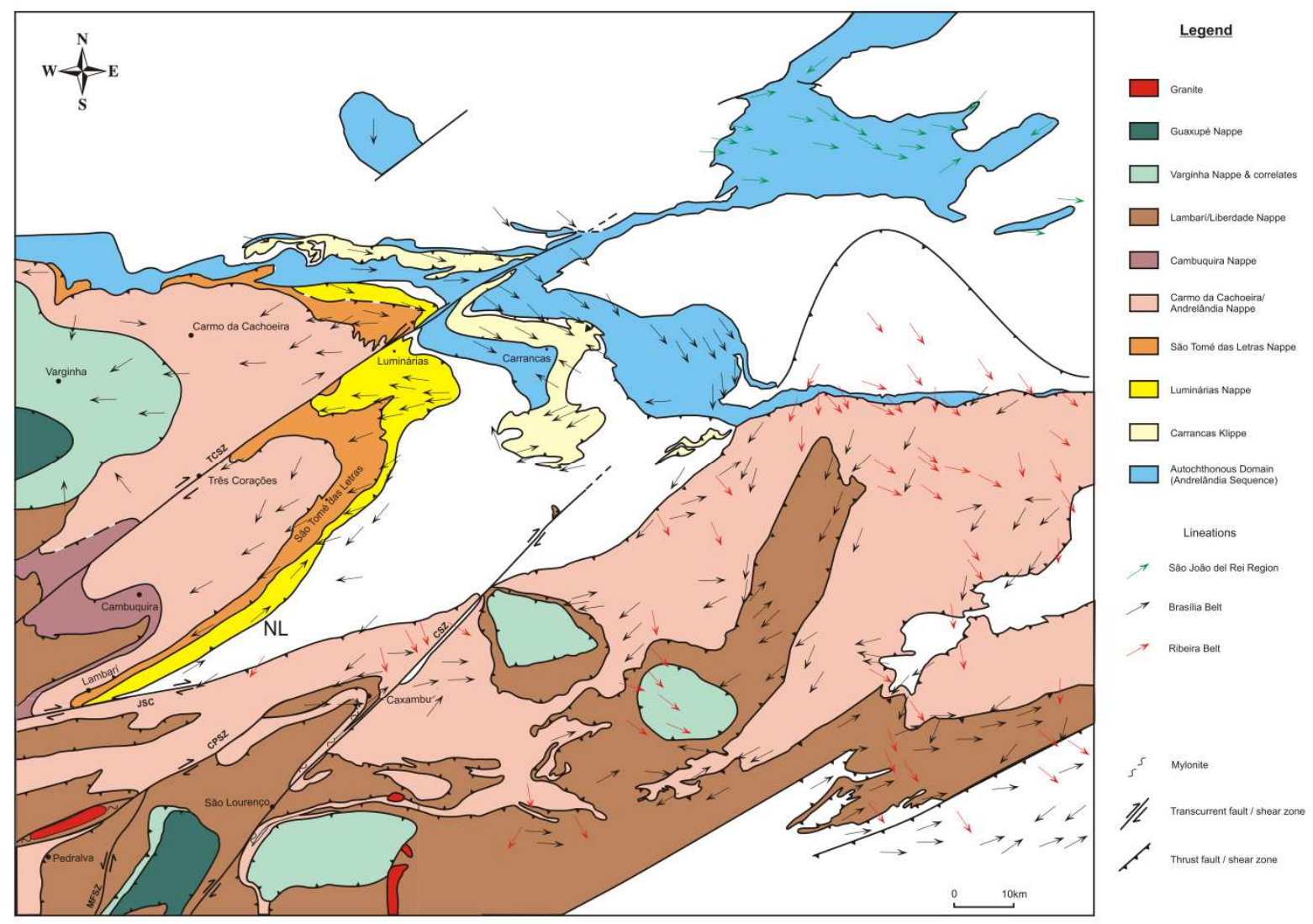

Figura IV.3: Mapa estrutural da zona de interferência das Faixas Brasilia e Ribeira, extraído de Trouw et al. (2000 b), que mostra os domínios autóctone e alóctone .

$\mathbf{D}_{3}$ : São dobras desde muito suaves até quase isoclinais. Em grande parte da área as dobras tem uma assimetria notável, resultando na freqüência da forma $\mathrm{Z}$ no mapa. Clivagem de crenulação $S_{3}$, além de lineação de crenulação $L_{3}$ bem marcantes localmente (Trouw et al., 
1983; Paciullo, 1983). Uma zona de falha com direção SW-NE, que atravessa grande parte da região, é subparalela a $S_{3}$, e associada a zonas de dobramento intenso. Por esta razão e por evidências microtectônicas, a falha foi interpretada como sendo gerada durante esta fase (Trouw et al., 1983).

Paciullo et al. (2002) consideram a Klippe Carvalhos e a Klippe Carrancas, e as nappes Liberdade e Andrelândia estruturas regionais da Faixa Brasília. A Nappe que contém os Gnaisses Piedade, a deflexão para norte da Nappe Liberdade e a antiformal de Bom Jardim de Minas seriam estruturas regionais da Faixa Ribeira para os mesmos autores.

\section{IV.4. Relação entre deformação e metamorfismo}

A primeira fase de deformação $\mathrm{D}_{1}$ é marcada pelo início do metamorfismo com crescimento ou recristalização dos primeiros minerais metamórficos a temperatura e pressão de fácies xisto verde. Clorita, mica branca, biotita, opacos, cloritóide cresceram e se orientaram segundo a clivagem ardosiana $S_{l}$, Alguns destes minerais podem ter origem detrítica, e posteriormente cresceram e/ou recristalizaram durante $\mathrm{D}_{1}$ (Heilbron 1985).

Posteriormente, pressão e temperatura começam a aumentar entre $\mathrm{D}_{1}$ e $\mathrm{D}_{2}$ com início de geração de granada e estaurolita. Pico metamórfico foi atingido durante $\mathrm{D}_{2}$ com crescimento de granada, cianita, estaurolita e $( \pm)$ sillimanita. Nos xistos e filitos houve a geração da foliação $S_{2}$ que transpôs (parcial ou totalmente) a clivagem ardosiana $S$, que foi amoldada aos porfiroblastos de granada, estaurolita e cianita, indicando que o crescimento destes minerais foi interrompido antes do término da deformação $\mathrm{D}_{2}$ (Heilbron, 1985).

A falta de cristais intercinemáticos indica que provavelmente não houve intervalo de tempo entre $\mathrm{D}_{1}$ e $\mathrm{D}_{2}$ e que estas seriam duas subfases de uma fase maior, também responsável pelos empurrões (Trouw et al., 1980). O campo de tensões alterado durante as deformações $\mathrm{D}_{1}$ e $\mathrm{D}_{2}$ é reequilibrado pela intensa recristalização de quartzo e micas após $\mathrm{D}_{2}$, ainda sob alta temperatura (Heilbron, 1985).

Ao fim da deformação $\mathrm{D}_{3}$ começa a cristalização de uma nova geração de clorita, cloritóide e muscovita que truncam estruturas dessa fase. Depois de $\mathrm{D}_{3}$, a recristalização foi insipiente e os efeitos da deformação ficaram preservados nos minerais através de extinção ondulante, bandas e lamelas de deformação (Heilbron, 1985).

A diminuição de temperatura na fase de deformação $\mathrm{D}_{3}$ é interpretada tanto como resultante do retrometamorfismo da trajetória metamórfica de pico em fácies anfibolito em $\mathrm{D}_{2}$ 
(Trouw et al., 1983) quanto como um segundo evento metamórfico de pico em fácies xisto verde separado no tempo daquele com pico metamórfico em $\mathrm{D}_{2}$ (Heilbron, 1985).

\section{5. Geocronologia}

\section{Sistema de Nappes Andrelândia}

A idade do metamorfismo foi investigada através de análises U-Pb TIMS em cristais de monazita nas rochas do sistema de nappes (Campos Neto et al., 2007, 2010 e 2011). Na nappe Andrelândia foram obtidos valores entre $606 \pm 2 \mathrm{Ma}$ (rochas em presença de cianita e sillimanita) e $611 \pm 2 \mathrm{Ma}$ (em presença de cianita). Para a nappe Liberdade as idades ficaram ao redor de $611 \pm 18$ Ma e 616 Ma. Cianita granulitos da Klippe Carvalhos possuem as idades mais antigas, 617,7 \pm 1,3 Ma. Indicam uma propagação normal do sistema de nappes, com as nappes inferiores mais jovens que as superiores. A idade de leucogranitos não deformados, intrusivos no Migmatito Alagoa, interior da Nappe Liberdade, pós-data em $596 \pm 5$ Ma o transporte sin-metamórfico deste sistema.

Cristais de zircão detrítico do Xisto Santo Antônio forneceram idade U-Pb TIMS neoproterozóica, de $668 \pm 28 \mathrm{Ma}$ (Campos Neto et al., 2004). Indica uma área fonte exótica ao Cráton do São Francisco e a idade máxima para a sedimentação desta unidade. Metabasalto toleítico retro-eclogítico da Nappe Liberdade possui idade magmática semelhante à dos grãos detríticos de zircão do Xisto Antônio, ou seja, U-Pb SHRIMP de $669 \pm 25$ Ma (Campos Neto et al., 2011).

Rochas arqueanas ocorrem no extremo sudoeste do sistema de nappes. São metatexitos tonalito-trondjemíticos, com restos de sequência máfico-ultramáficas, que definem o Complexo Migmatítico Amparo de 2,85 Ga. Tonalito gnaisses, em parte metatexíticos do Complexo Serra Negra, aparentemente são intrusivos e possuem 2,77 Ga. Ambos foram submetidos a um metamorfismo fácies anfibolito superior com anatexia há 2,04 Ga (Tassinari e Nutman, 2001; Fetter et al., 2001). Migmatitos polimetamórficos, com protolitos em uma suíte plutônica cálcio-alcalina tonalito-granodiorito-granítica, ocorrem no interior e na base da Nappe Liberdade. São rochas riacianas (idades U-Pb TIMS em zircão entre 2,05 Ga - 2,15 Ga) em parte com assinaturas Nd juvenis (Fetter et al., 2001; Peternel et al., 2005; Campos Neto et al., 2004 e 2011).

\section{$\underline{\text { Sistema de Nappes Carrancas }}$}


Valladares et al. (2004) analisaram grãos detríticos de zircão, por LA-ICPMS, de quartzitos da Formação Campestre nos domínios tidos como alóctone e autóctone. Obtiveram idades ${ }^{207} \mathrm{~Pb} /{ }^{206} \mathrm{~Pb}$ entre $1,0 \mathrm{Ga}$ e 3,1 Ga, com predomínio de idades entre $1200 \mathrm{Ma}-1300 \mathrm{Ma}$ e $2100 \mathrm{Ma}$ - $2200 \mathrm{Ma}$. A idade máxima indicada para a sedimentação foi de 1,05 Ga.

O metamorfismo registrado pela monazita (U-Pb TIMS) na frente do sistema de nappes Carrancas encontra-se entre 590 Ma e 575 Ma (Valeriano et al., 2004; Campos Neto et al., 2011).

\section{IV.6. Paleoambiente deposicional}

Será considerado neste item o trabalho de Paciullo et al. (2002), pois este faz considerações sobre o possível ambiente deposicional das unidades da região (tabela IV.11).

\begin{tabular}{|c|c|c|}
\hline & UNIDADE & AMBIENTE DEPOSICIONAL \\
\hline \multirow{2}{*}{$\begin{array}{c}\text { SEQUÊNCIA SERRA DO } \\
\text { TURVO }\end{array}$} & $\mathrm{Na}_{6}$ & $\begin{array}{l}\text { Pelas associações de litofácies - rochas pelíticas e } \\
\text { semi-pelíticas com intercalações de rochas máficas, } \\
\text { calciossilicáticas, e chert, esta unidade é interpretada } \\
\text { como sucessão distal da megassequencia Andrelândia } \\
\text { depositada sobre assoalho oceânico, provavelmente } \\
\text { constituída por depósitos turbidíticos e hemipelágicos } \\
\text { de fundo marinho. }\end{array}$ \\
\hline & $\mathrm{Na}_{5}$ & $\begin{array}{l}\text { Interpretada regionalmente como uma sucessão } \\
\text { constituída, na base, por turbiditos pelíticos (domínios } \\
\text { alóctones), localmente com seixos pingados e, no topo, } \\
\text { por pelitos hemipelágicos transgressivos (domínio } \\
\text { autóctone). Representariam assim, sedimentação em } \\
\text { períodos de mar baixo e mar alto, relacionado a } \\
\text { variações glacio-eustáticas. }\end{array}$ \\
\hline $\begin{array}{l}\text { SEQUÊNCIA } \\
\text { CARRANCAS }\end{array}$ & $\mathrm{Na}_{4}$ & $\begin{array}{l}\text { São interpretadas como parassequências } \\
\text { retrogradacionais depositadas em trato de sistema de } \\
\text { mar alto. Representam um período de inundação } \\
\text { máxima da bacia, com pelitos ultrapassando o limite } \\
\text { sul da bacia original e recobrindo a unidade } \mathbf{N a}_{1+2} \text {, } \\
\text { embasamento e pelitos da Megassequencia Carandaí } \\
\text { nas folhas Lavras e São João Del Rei. }\end{array}$ \\
\hline
\end{tabular}

Tabela IV.11: paleoambientes possíveis para unidades da Megassequência Andrelândia, segundo Paciullo et al. (2002). 


\begin{tabular}{|c|c|c|}
\hline \multirow[t]{3}{*}{$\begin{array}{l}\text { SEQUÊNCIA } \\
\text { CARRANCAS }\end{array}$} & $\mathrm{Na}_{3}$ & $\begin{array}{l}\text { Trata-se de quartzo metarenitos com intercalações delgadas } \\
\text { de metapelitos e raros metaconglomerados, interpretados } \\
\text { como parassequências agradacionais plataformais (shoreface) } \\
\text { depositadas em trato de sistema transgressivo. Os quartzitos } \\
\text { incluem lentes delgadas e lâminas de xistos com muscovita } \\
\text { esverdeada que ocorrem separando camadas de quartzitos, } \\
\text { representando superfícies de inundação ou recobrimento } \\
\text { pelítico em estratos cruzados. Nas sucessões quartzíticas da } \\
\text { Klippe Carrancas predomina a estratificação média a espessa } \\
\text { com poucas intercalações pelíticas, enquanto nas nappes } \\
\text { Luminárias e São Tomé das Letras, predomina a estratificação } \\
\text { média a delgada com maior quantidade de intercalações } \\
\text { pelíticas. Essas variações faciológicas são interpretadas como } \\
\text { devido à diferentes posições desses depósitos na bacia } \\
\text { sedimentar original. Por outro lado, para Trouw et al. (2002) } \\
\text { as freqüentes intercalações de lâminas micáceas parecem } \\
\text { registrar breves períodos de detenção de correntes e } \\
\text { decantação de finos, sugerindo ambiente dominado por marés. }\end{array}$ \\
\hline & $\mathbf{N a}_{2}$ & $\begin{array}{l}\text { Todo o conjunto é interpretado como parassequências } \\
\text { retrogradacionais de trato de sistema transgressivo. Os } \\
\text { quartzitos e xistos representam a franca entrada do mar na } \\
\text { bacia (retrogradação), culminando na deposição das unidades } \\
\text { seguinte } \mathrm{Na}_{3} \mathrm{e} \mathrm{Na}_{4} \text {, }\end{array}$ \\
\hline & $\mathrm{Na}_{1}$ & $\begin{array}{l}\text { Os paragnaisses são interpretados como intercalações de } \\
\text { arenitos feldspáticos e pelitos. Essa associação é interpretada } \\
\text { como possivelmente depositada em ambientes parálicos } \\
\text { (planície costeira?) e como depósitos turbidíticos, em período } \\
\text { de trato de sistema de mar baixo, nos primórdios do } \\
\text { preenchimento da bacia sedimentar. Os anfibolitos } \\
\text { representam atividade ígnea máfica contemporâneos: basaltos } \\
\text { subalcalinos toleíticos, de composições químicas semelhantes } \\
\text { aos basaltos continentais e de fundo oceânico tipo MORB } \\
\text { enriquecido (Paciullo 1997). }\end{array}$ \\
\hline
\end{tabular}

Continuação tabela IV.11: paleoambientes possíveis para unidades da Megassequência Andrelândia, segundo Paciullo et al. (2002). 


\section{CAPÍtUlo V}

\section{LITOTIPOS AMOSTRADOS}

As unidades geológicas do Grupo Carrancas na região, como descritas por Trouw et al (1980), admitem, simplificadamente, uma sequência quartzítica basal, com intercalações subordinadas de muscovita-quartzo xisto e de grafita-muscovita xisto (Formação São Tomé das Letras), sobreposta por uma sequência de grafita-muscovita xisto com alternâncias subordinadas de quartzitos (Formação Campestre). As rochas pelíticas registram um aumento das condições metamórficas de norte para sul, a partir de paragêneses fácies xisto verde $(\mathrm{Mg}$ clorita-muscovita-cloritóide) e de fácies xisto-verde de alta pressão (muscovita-cloritóidecianita-granada). A entrada no campo da estaurolita (fácies anfibolito inferior) é gradual, com coexistência de cloritóide-estaurolita, seguida por paragêneses a estaurolita-muscovita-Mg clorita-cianita-granada. As condições de maior temperatura foram atingidas na Chapada das Perdizes, sul da Serra das Bicas, registradas pela paragênese granada-cianita-biotita, estaurolita ausente. A sillimanita é rara, intersticial e associada à trajetória de descompressão no soerguimento da pilha de nappes (Silva, 2010).

A unidade Biotita Xisto, preservada entre e as serras do Grupo Carrancas, não atingiu condições metamórficas de fácies anfibolito. Apresenta paragênese de granada-muscovita-Mg clorita-(biotita-plagioclásio) e de granada-muscovita-biotita-(Mg-clorita-plagioclásio), sugerindo um aumento de temperatura, sob condições xisto verde, também de norte para sul.

$\mathrm{O}$ pico metamórfico foi atingido durante a fase $\mathrm{D}_{2}$ da deformação, evidenciado por cristais de granada e estaurolita sin- tardi-cinemáticos. A temperatura continuou elevada em estágios pós-cinemáticos, evidenciada por cristais idiomórficos e pós-foliação de granada e de estaurolita em rochas de fácies anfibolito e de cloritóide em rochas de fácies xisto-verde. A diminuição de temperatura e pressão, e conseqüente retrometamorfismo, ocorrem pós-S2, pré a sin-S3 (clivagem de crenulação). O retrometamorfismo é marcado pela substituição de estaurolita e granada por cloritóide nos xistos grafitosos, e pela substituição de granada por clorita na unidade Biotita Xisto. Em algumas amostras, identificou-se foliação $\mathrm{S}_{3}$ associada ao retrometamorfismo, marcada pela cristalização de muscovita, clorita ou cloritóide retrometamórfico. 
Essas rochas, tidas em um domínio autóctone em relação ao Cráton do São Francisco, foram amostradas entre as Formações São Tomé das Letras e Campestre (figura V.1 - Anexo II), alóctones e tidas na Klippe Carrancas (Trouw et al., 2000 a, b).

\section{V.1. Unidade Biotita Xisto (UBX) - Pranchas de fotos I, II, III e IV (Anexo III)}

Aflora geralmente na forma de lajes extensas, podendo ocorrer em drenagens e como blocos rolados (Figura V.2). A rocha que representa esta unidade apresenta coloração acinzentada, estrutura xistosa e textura que varia entre granolepidoblástica, lepidogranoblástica e porfiroblástica. A mineralogia principal é composta por biotita, muscovita, plagioclásio e quartzo, os dois últimos em proporções variadas. Clorita ocorre determinando a foliação da rocha na região próxima a Serra do Pombeiro e porfiroblastos de granada são observados frequentemente nos afloramentos próximos a Serra das Bicas.

Intensamente crenulados e dobrados, os afloramentos apresentam vênulas de quartzo, que acompanham o padrão de deformação da rocha, na forma de sigmóides, mullions e lentes dobradas e descontínuas.

Os alforamentos alterados são de coloração avermelhada e identificados pelos porfiroblasto de granada e lentes descontínuas de quartzo que resistem a processos intempéricos.

\section{$\underline{\text { Petrografia }}$}

Rocha de granulação fina a média e estrutura xistosa, alterna porções de textura lepidoblástica com porções granoblásticas. Composta principalmente por biotita, muscovita e quartzo, pode apresentar concentrações variadas de opacos, clorita, granada e plagioclásio, com algumas amostras apresentando carbonato (CAR-I-51) e turmalina como minerais acessórios.

Os porfiroblastos de granada, quando intercinemáticos (Passchier e Trouw, 1996; Vernon, 2004) registram uma fase deformacional anterior a foliação principal $\left(S_{2}\right)$ e um zonação textural (núcleo com inclusões orientadas e obliquas à foliação externa principal e borda límpida e idiomórfica. Microporfiroblastos idiomórficos e límpidos são comuns. As porções granoblásticas são formadas principalmente por quartzo e, subordinadamente, plagioclásio (CAR-I-51, CAR-IV-06, CAR-IV-06a, CAR-IV-06ba, CAR-IV-42, C-300, C309b, C-325b). O quartzo ocorre em cristais poligonizados e sem extinção ondulante, recristalizados dinamicamente por redução de borda de grãos até estágios pós-cinemáticos - 
recristalização estática. Estágios iniciais deste processo, registrados em cristais amebóides e com extinção ondulante e extinção em zona de plagioclásio também são comuns. $\mathrm{O}$ plagioclásio, quando ocorre, é sericitizado e de granulação mais grossa do que o quartzo, podendo ocorrer como porfiroblastos deformados (C-410, C-410a e C-411).

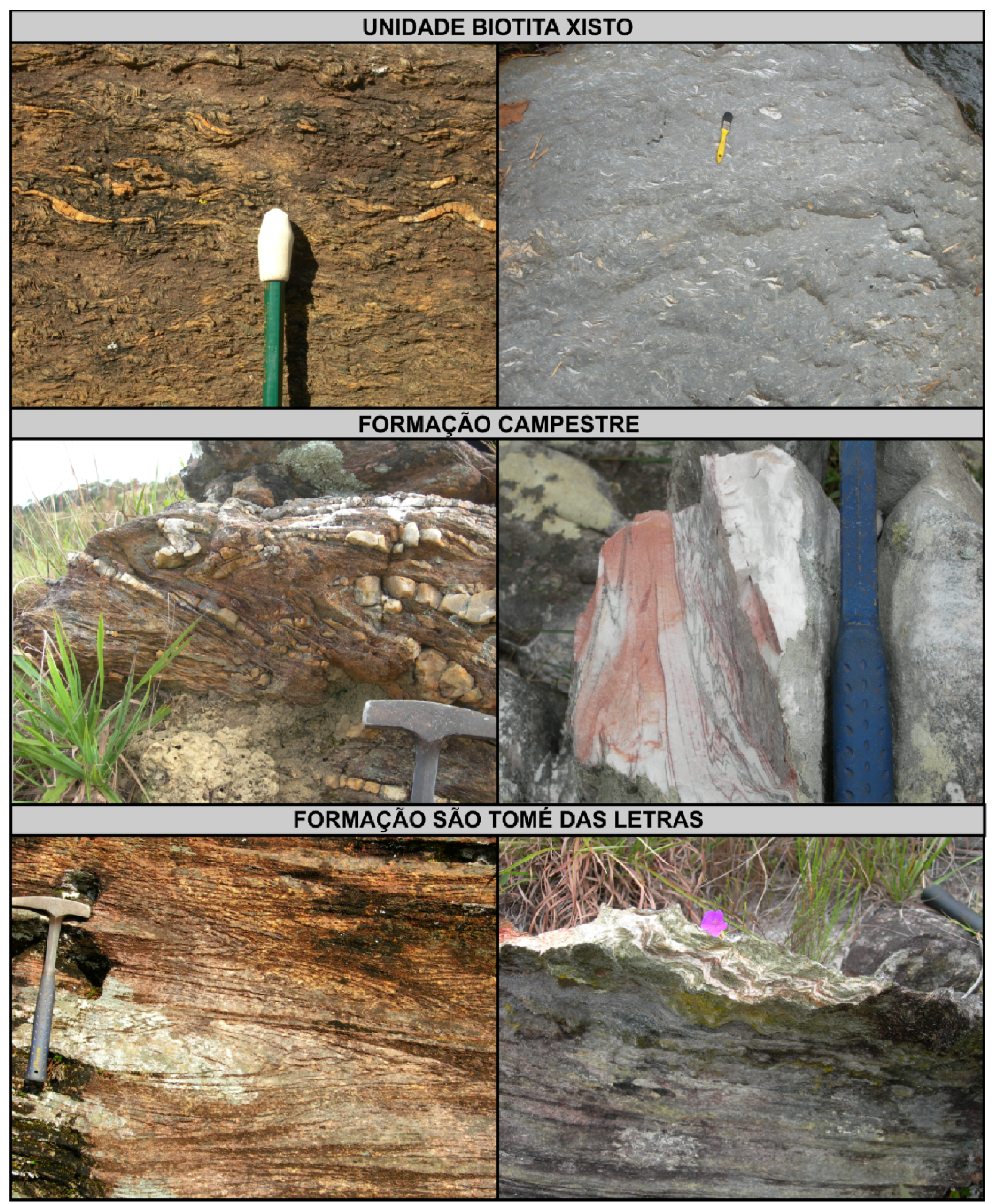

Figura V.2: afloramentos da Unidade Biotita Xisto e das formações Campestre e São Tomé das Letras. 
As porções lepidoblásticas são formadas por muscovita e biotita, com clorita subordinada, substituindo granada e biotita (na região a leste da serra das Bicas) e por muscovita e clorita, com biotita subordinada, substituindo a clorita da foliação (na região a sul das serras do Pombeiro e Estância). Essa variação, aliada aos porfiroblastos de granada em presença de biotita, deve estar controlada pelo aumento de temperatura (e pressão) dentro das condições metamórficas de fácies xisto verde. Portanto, as rochas variam de granada-cloritabiotita-muscovita-(plagioclásio)-quartzo xisto, a norte (sul das serras da Estância e Pombeiro), até granada-muscovita-biotita-(plagioclásio)-quartzo xisto, a leste da serra das Bicas.

As rochas desta unidade são intensamente deformadas o que pode ser visto por dobras, microlithons, muscovita fish e sigmóides de foliação. A foliação principal é uma $\mathrm{S}_{2}$, definida por arcos poligonais de biotita e muscovita e por dobras intrafoliais. A foliação $\mathrm{S}_{2}$ encontra-se crenulada em algumas amostras e dobrada em outras, podendo gerar ou não uma foliação $\mathrm{S}_{3}$ marcada pelas micas.

Veios de quartzo descontínuos, característicos desta unidade, são fortemente recristalizados, dobrados, na forma de sigmóides e muitas vezes orientados segundo $S_{3}$,

\section{V.2. Formação Campestre (FC) - Pranchas de fotos I, V, VI e VII (Anexo III)}

Caracterizada pela alternância entre quartzito com muscovita, muscovita quartzito e grafita-muscovita xisto (figura V.2).

\section{V.2.1. Grafita-muscovita xisto}

Esta rocha apresenta estrutura xistosa e textura que varia entre lepidoblástica e porfiroblástica. A mineralogia principal é composta por muscovita e grafita, com presença de estaurolita, granada e cianita ao sul da área estudada e cloritóide e $\mathrm{Mg}$ clorita ao norte. Quartzo, com exceção de níveis delgados de muscovita xistos, localmente com cianita, está sempre presente na matriz, em concentrações variadas. Pares S/C crenulados e injeções de material quartzo-feldspático dobrado com a foliação foram observados em campo.

\section{$\underline{\text { Petrografia }}$}

Rochas de estrutura xistosa e granulação fina, com textura que varia de nematolepidoblástica, lepidoblástica e porfiroblástica, podendo apresentar amostras nematoblásticas, com lentes descontínuas granoblásticas. 
A mineralogia é variada e define lentes de diferentes composições dentro da unidade, mas todas têm em comum a presença de grafita e muscovita, em diferentes proporções:

(i) amostra C-318: formada por muscovita, estaurolita e grafita com matriz rica em quartzo de granulação fina e intensamente recristalizado. Lentes descontínuas de quartzo são comuns e os cristais de estaurolita são tardi- a pós cinemáticos, identificados por foliação interna no núcleo compatível com a externa principal $\left(\mathrm{S}_{2}\right)$ e bordas idiomórficas sem inclusões;

(ii) amostras CAR-IX-11, C-308a, C-317, C-421 e C-426: caracterizadas pela presença de porfiroblastos de granada e estaurolita em matriz rica em quartzo e muscovita e cloritóide. Granada sin-cinemática, com foliação interna rotacionada em relação à externa principal $\left(\mathrm{S}_{2}\right)$. Estaurolita tardi- a pós-cinemática com foliação interna oblíqua a externa principal $\left(\mathrm{S}_{2}\right)$ e bordas idiomórficas e sem inclusões. Os cristais de cloritóide determinam a foliação principal com os cristais de muscovita, sendo que cristais cristalizados no plano axial $\left(\mathrm{S}_{2}\right)$ de microdobras resultantes da crenulação de $S_{2}$ foram observados. $\mathrm{Na}$ amostra $\mathrm{C}-426$ os polimorfos de granada foram completamente substituídos por estaurolita e posteriormente cloritóide;

(iii) amostras CAR-I-32, CAR-II-76, CAR-II-108, CAR-IV-52b, CAR-IV-129, CARIV-152, C-397, C-400, C-421b: lentes granoblásticas de quartzo intercaladas com lentes nematolepidoblásticas formadas por muscovita, cloritóide e grafita. Polimorfos de granadas substituídos por cloritóide e muscovita foram observados, algumas vezes associados a estaurolita. Cloritóides fish foram identificados na amostra CAR-II-108 e clorita substitui cristais de granada na amostra C-421b;

(iv) amostras CAR-V-17, C-375, C-376 e C-399c: intercalação de lentes granoblásticas de quartzo e lepidoblásticas formadas por muscovita e grafita. Possíveis polimorfos de granada observados;

(v) amostras C-344 e C-381b: rocha formada essencialmente por muscovita, grafita e estaurolita, idiomórfica e pós-cinemática. Muscovita define a foliação $\mathrm{S}_{2}$ principal e também se cristaliza em $\mathrm{S}_{3}$;

(vi) amostras C-301b, C-379, C-381b e C-412: rocha formada essencialmente por muscovita e grafita com cianita (C-301b), turmalina (CAR-I-32) e opacos como minerais acessórios.

Portanto, foram encontrados desde cloritóide-grafita-muscovita xistos com granada subordinada até estaurolita-grafita-muscovita-cloritóide xistos com granada, passando por 
cloritóide-grafita-muscovita xisto e granada-muscovita-grafita-cloritóide-estaurolita xisto. além de muscovita xistos com cianita.

As amostras ricas em muscovita registram as várias fases de deformação, e são intensamente crenuladas. A foliação principal é $S_{2}$, identificada pela presença de dobras intrafoliais $\mathrm{D}_{2}$, microlithons preservados em sombras de pressão de porfiroblastos de granada e entre a foliação principal e arcos poligonais de cloritóide e muscovita com plano axial paralelo à foliação principal. A crenulação de $S_{2}$ gerou dobras abertas com plano axial oblíquo à $\mathrm{S}_{2}$, sendo que em algumas amostras foram observados cloritóide e muscovita definindo a foliação $\mathrm{S}_{3}$,

As porções granoblásticas quando ocorrem são formadas essencialmente por quartzo, fortemente recristalizados. Lentes quartzosas descontínuas, quando observadas, são afetadas pela fase de deformação $\mathrm{D}_{2}$ e pela crenulação $\mathrm{D}_{3}$,

\section{V.2.2. Quartzito}

O quartzito é formado essencialmente por quartzo e muscovita, tem estrutura foliada e textura granolepidoblástica. Assim como o xisto, encontra-se fortemente deformado, o que pode ser observado por dobras intrafoliais e pela crenulação.

\section{$\underline{\text { Petrografia }}$}

Rocha de granulação fina a média, de textura granoblástica a lepidogranoblástica, de estrutura maciça a levemente foliada, formada essencialmente por quartzo e muscovita com opacos como minerais acessórios principais. As amostras variam de quartzito com muscovita até muscovita quartzitos.

Os cristais de quartzo não estão orientados segundo uma direção preferencial, têm extinção ondulante e contatos amebóides, sugerindo estágios iniciais de recristalização em estado sólido. A muscovita ocorre em lentes, com cristais orientados e sua concentração varia de $<5 \%$ a $20 \%$ da rocha.

A deformação sofrida pela rocha que afetou a foliação principal é registrada na forma de mullions, dobras e muscovita fish.

\section{V.3. Formação São Tomé das Letras - Prancha de fotos VIII}

Ocorre na forma de lentes espessas e diferencia-se do quartzito da unidade anterior por apresentar muscovita verde em escala mesoscópica, além de não apresentar alternância 
recorrente com o xisto grafitoso (figura V.2). Os quartzitos têm estrututa que varia de maciça a xistosa e textura granoblástica a lepidogranoblástica, dependendo da quantidade de muscovita presente. Quartzo e muscovita verde são os minerais principais e turmalina é o acessório mais comum

Assim como as outras unidades, apresenta-se fortemente crenulado, com mullions e veios de quartzo afetados pela deformação.

\section{$\underline{\text { Petrografia }}$}

As rochas desta formação variam de muscovita quartzitos a muscovita xistos e são caracterizadas pela presença de muscovita verde e turmalina.

O muscovita xisto caracteriza-se pela presença de mullions e arcos poligonais de muscovita entre a foliação principal evidenciando foliação $S_{1}$ anterior à $S_{2}$ principal, características observadas nas outras amostras analisadas. A foliação $S_{3}$ é observada na forma de cristais de muscovita orientados obliquamente à foliação principal.

Os cristais de quartzo são intensamente recristalizados, com contatos poligonais predominantes sobre os contatos lobados.

As rochas desta formação, quando ricas em quartzo, se diferem do quartzito da Formação Campestre pela presença de turmalina e pela coloração esverdeada da muscovita. 


\section{CAPÍTULO VI}

\section{Geoquímica Elemental}

As amostras da Unidade Biotita Xisto (UBX) analisadas foram agrupadas segundo a estrutura em que foram coletadas (Anexo I e tabela VI.1), para que possíveis diferenças geoquímicas pudessem ser identificadas. As amostras coletadas a leste da Serra das Bicas, sob o cavalgamento das unidades do Grupo Carrancas, estão agrupadas na denominação UBX SB. As amostras coletadas a sul da Serra Pombeiro, em uma estrutura sinformal alóctone sobre o Grupo Carrancas, em UBX - SP.

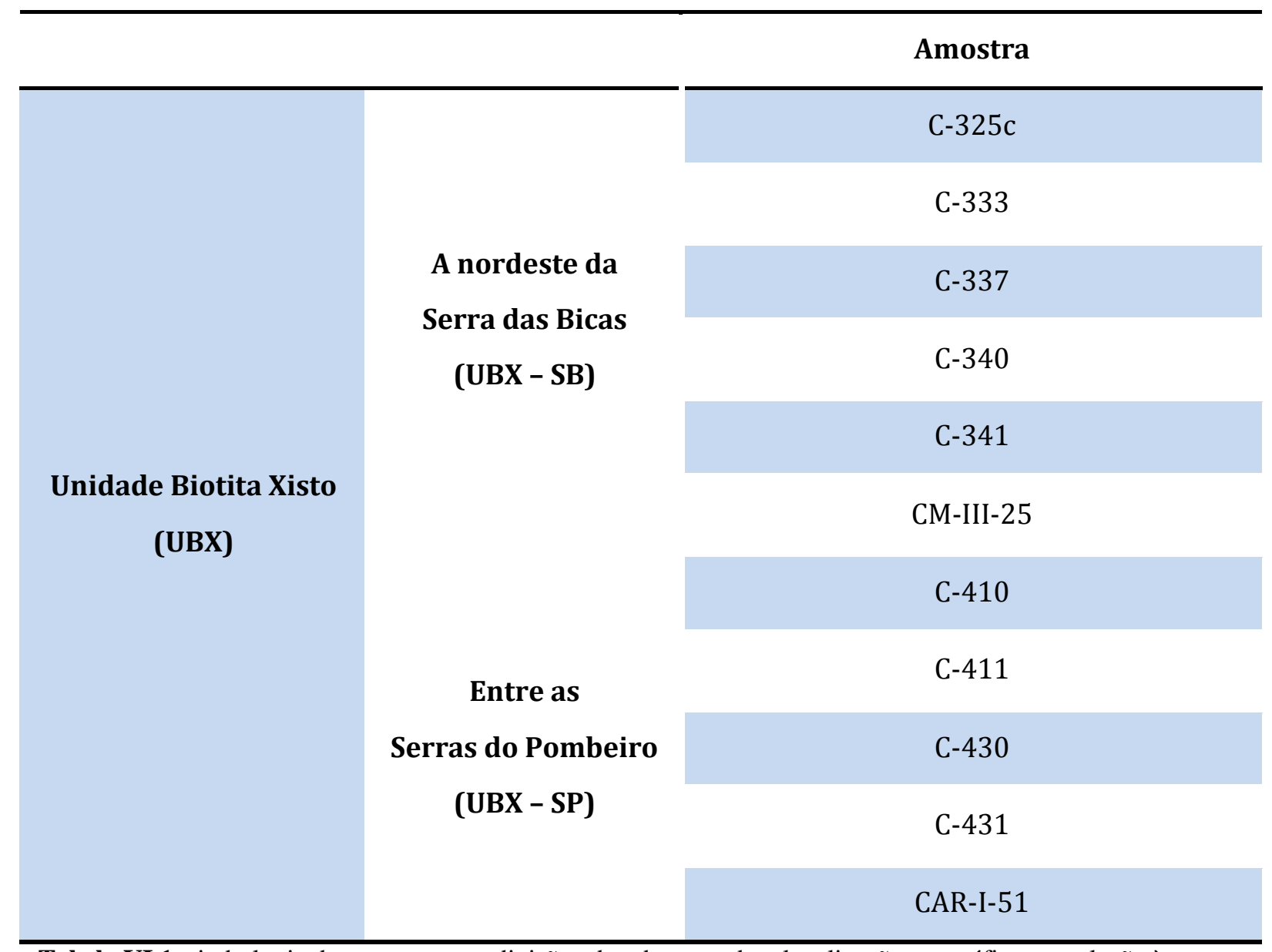

Tabela VI.1: simbologia das amostras e a divisão adotada segundo a localização geográfica em relação às serras das Bicas e do Pombeiro e a estrutura regional. 
As diferenças químicas são poucas entre esses grupos de amostras, confirmando a correlação de campo e petrográfica dessas rochas (expressas e mapeadas por Quéméneur et al., 2002). No entanto, quando analisadas no seu conteúdo isotópico e em elementos traços , destacam-se diferenças na natureza da área-fonte e no clima, intemperismo e reciclagem do sedimento, quando dos processos de erosão, transporte e sedimentação.

\section{VI.1. Elementos maiores e menores}

As amostras analisadas apresentam valores aproximados com teores intermediários de $\mathrm{SiO}_{2}\left(58,25\right.$ - 68,09) valores de $\mathrm{CaO}$ e $\mathrm{Na}_{2} \mathrm{O}$ baixos $(0,22$ - 1,49 e 1,79 - 2,92) e valores de $\mathrm{Al}_{2} \mathrm{O}_{3}, \mathrm{Fe} 2 \mathrm{O} 3, \mathrm{~K}_{2} \mathrm{O}$ e $\mathrm{MgO}$ entre 14,63 - 19,69, 5,65 - 7,92, 2,9 - 4,69 e 2,32 - 3,48, respectivamente (tabela VI.2).

As concentrações de $\mathrm{Al}_{2} \mathrm{O}_{3}, \mathrm{Fe}_{2} \mathrm{O}_{3}, \mathrm{~K}_{2} \mathrm{O}$ e $\mathrm{MgO}$ são maiores quanto maior a proporção de minerais micáceos em relação ao quartzo, determinada em análises petrográficas, indicando que estes elementos estão condicionados à presença de muscovita $\left[\mathrm{KAl}_{2}\left(\mathrm{AlSi}_{3} \mathrm{O}_{10}\right)(\mathrm{OH})_{2}\right], \quad$ biotita $\left[\mathrm{K}(\mathrm{Mg}, \mathrm{Fe})_{3}\left(\mathrm{AlSi}_{3} \mathrm{O}_{10}\right)(\mathrm{OH})_{2}\right]$ e clorita $\left[(\mathrm{Mg}, \mathrm{Fe})_{3}(\mathrm{Si}, \mathrm{Al})_{4} \mathrm{O}_{10}(\mathrm{OH})_{2},(\mathrm{Mg}, \mathrm{Fe})_{3}(\mathrm{OH})_{6}\right]$, minerais estes formados a partir do metamorfismo de argilominerais. A presença de plagioclásio rico em albita e carbonato na amostra CAR-I-51 é responsável pelo relativo alto teor de $\mathrm{Na}_{2} \mathrm{O}$ e $\mathrm{CaO}$ nesta amostra. A concentração de $\mathrm{Na}_{2} \mathrm{O}$ também é alta na amostra C-410 que apresentou cristais de plagioclásio de granulação grossa em lâmina petrográfica. A relação diretamente proporcional entre $\mathrm{CaO}$ e $\mathrm{P}_{2} \mathrm{O}_{5}$ e a presença de apatita em todas as amostras analisadas petrograficamente indicam que este mineral pesado condiciona as concentrações destes elementos nas amostras.

Os elementos maiores e menores foram plotados em diagramas de Harker (figura VI.1) que, de um modo geral, demonstram que a correlação entre $\mathrm{SiO}_{2}$ vs. $\mathrm{Al}_{2} \mathrm{O}_{3}, \mathrm{Fe}_{2} \mathrm{O}_{3}$, $\mathrm{MnO}, \mathrm{MgO}$ e $\mathrm{K}_{2} \mathrm{O}$ é negativa e entre $\mathrm{SiO}_{2}$ vs. $\mathrm{P}_{2} \mathrm{O}_{5}, \mathrm{TiO}_{2}, \mathrm{CaO}$ e $\mathrm{Na}_{2} \mathrm{O}$ positiva. Com exceção dos diagramas de $\mathrm{SiO}_{2}$ vs. $\mathrm{Al}_{2} \mathrm{O}_{3}$ e $\mathrm{Fe}_{2} \mathrm{O}_{3}$, as amostras se subdividem em dois grupos que partem de composições diferentes, provavelmente devido à diferenças composicionais do sedimento ocasionada por diferenças geoquímicas na área-fonte.

Transporte e deposição de sedimentos durante processos de erosão e intemperismo podem ter sido responsáveis pela correlação negativa entre $\mathrm{SiO}_{2}$ e os demais elementos químicos, pois argilominerais, geralmente ricos em $\mathrm{Al}, \mathrm{Fe}, \mathrm{Mg}$ e $\mathrm{K}$, tendem a se concentrar na fração silte/argila do sedimento, diferentemente de quarzto e feldspato que tendem a se 
concentrar em frações arenosas, resultando na diminuição de $\mathrm{Si}$ e $\mathrm{Na}$ fração silte/argila (Taylor e McLennan, 1985).

Por outro lado, o fracionamento de minerais pesados como apatita pode ter sido responsável pela correlação positiva entre $\mathrm{SiO}_{2}$ e os óxidos $\mathrm{CaO}$ e $\mathrm{P}_{2} \mathrm{O}_{5}$, pois a alta densidade destes minerais faz com que sua deposição ocorra em frações de granulação mais grossa.

Sugere-se, assim, que as amostras enriquecidas em $\mathrm{Al}, \mathrm{Fe}, \mathrm{Mg}$ e $\mathrm{K}$, sobretudo 3 amostras agrupadas no alóctone a sul da Serra do Pombeiro (C-411, C-430 e C-431), possuíam um maior conteúdo em argilo-minerais, provavelmente devido ao depósito em domínios mais distantes da área fonte, ou devido alternâncias na atividade tectônica sinsedimentar, isto é, foram depositadas em um período tectonicamente mais estável. As amostras enriquecidas em Si, $\mathrm{P}$ e Ca resultam de depósitos de granulação mais grossa, mais proximais à área-fonte, ou depositadas em períodos tectonicamente mais ativos.

\begin{tabular}{cccccccccccc}
\hline Amostras & $\mathbf{S i O}_{2}$ & $\mathrm{TiO}_{2}$ & $\mathrm{Al}_{2} \mathbf{O}_{3}$ & $\mathbf{F e}_{2} \mathbf{O}_{3}$ & $\mathbf{M n O}$ & $\mathbf{M g O}$ & $\mathbf{C a O}$ & $\mathbf{N a}_{2} \mathbf{O}$ & $\mathbf{K}_{2} \mathbf{O}$ & $\mathbf{P}_{2} \mathbf{O}_{5}$ \\
\hline C-325c & 67,91 & 0,87 & 14,63 & 5,65 & 0,10 & 2,32 & 1,19 & 2,47 & 2,90 & 0,19 \\
C-333 & 64,30 & 0,85 & 15,71 & 6,54 & 0,13 & 2,75 & 1,14 & 2,56 & 3,33 & 0,20 \\
C-337 & 65,81 & 0,85 & 14,97 & 6,36 & 0,11 & 2,72 & 1,34 & 2,49 & 3,09 & 0,18 \\
\hline C-340 & 61,32 & 0,91 & 17,29 & 7,10 & 0,11 & 3,03 & 0,83 & 2,57 & 3,76 & 0,17 \\
\hline C-341 & 65,63 & 0,92 & 15,12 & 6,22 & 0,13 & 2,63 & 1,49 & 2,81 & 2,92 & 0,21 \\
\hline CM-III-25 & 62,60 & 0,80 & 16,61 & 7,17 & 0,10 & 3,02 & 0,42 & 1,88 & 3,88 & 0,12 \\
\hline C-410 & 68,09 & 0,86 & 14,14 & 6,04 & 0,09 & 2,51 & 0,64 & 2,78 & 2,69 & 0,18 \\
\hline C-411 & 58,25 & 0,92 & 19,69 & 7,92 & 0,10 & 3,45 & 0,22 & 1,79 & 4,61 & 0,14 \\
\hline C-430 & 61,31 & 0,93 & 17,70 & 7,55 & 0,13 & 3,48 & 0,87 & 2,33 & 4,00 & 0,16 \\
\hline C-431 & 60,19 & 0,93 & 17,81 & 7,73 & 0,13 & 3,26 & 0,80 & 2,07 & 4,69 & 0,16 \\
\hline CAR-I-51 & 62,83 & 1,03 & 16,46 & 6,68 & 0,17 & 2,76 & 1,90 & 2,92 & 3,20 & 0,22 \\
\hline
\end{tabular}

Tabela VI.2: resultados obtidos para elementos maiores e menores por análises de FRX. Valores em \% peso de óxido. 

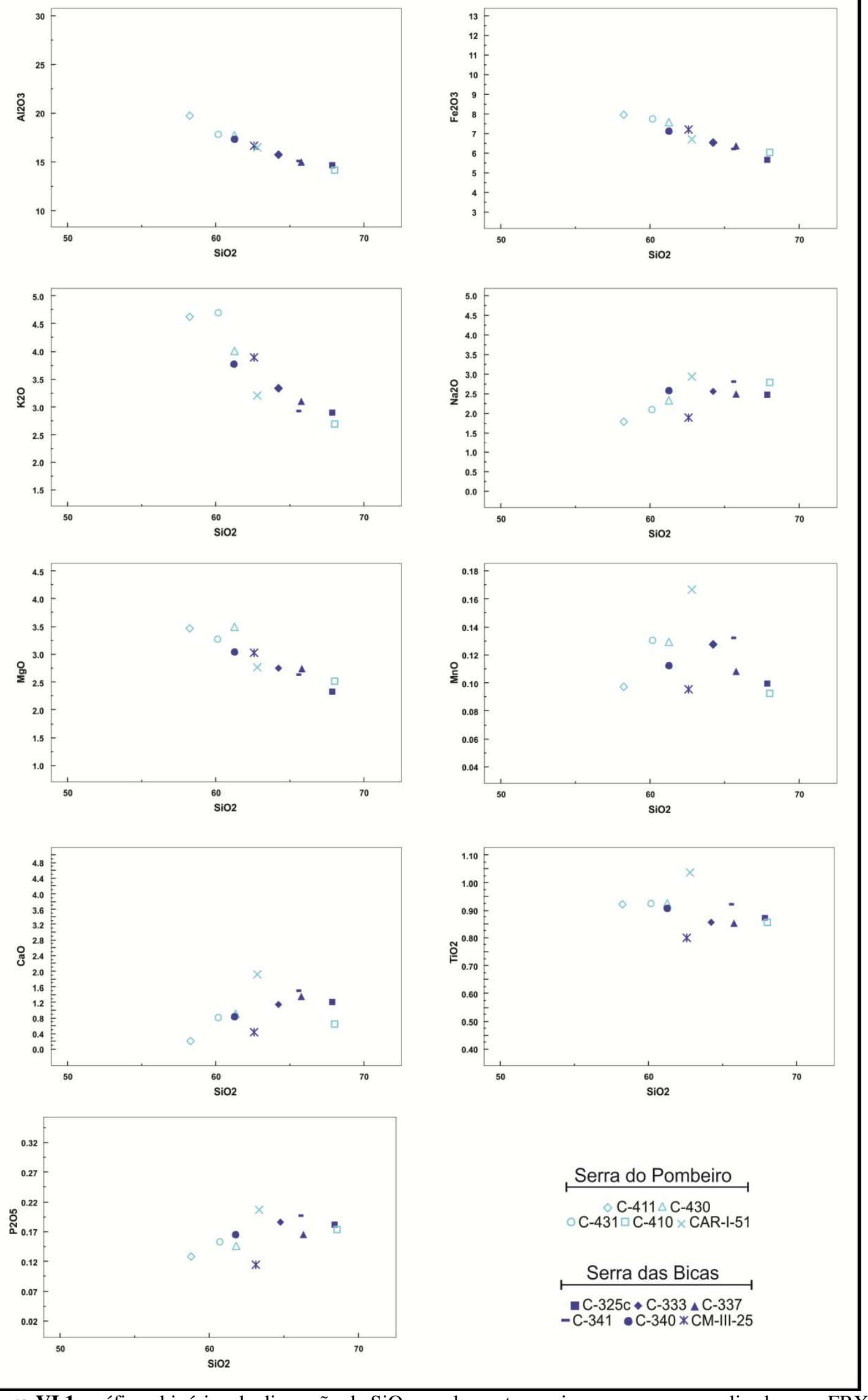

Figura VI.1: gráficos binários de dispersão de $\mathrm{SiO}_{2}$ vs. elementos maiores e menores analisados por FRX.

68 


\section{VI.1.1. Classificação}

No diagrama de Pettijohn et al. (1972 - figura VI.2), com exceção das amostras C411, C-431 e CM-III-25 todas as rochas foram classificadas como graywacke. As três exceções são enriquecidas em alumínio, potássio e em $\mathrm{Fe}_{2} \mathrm{O}_{3}$ em relação às demais amostras e são rochas que possuem um maior volume de muscovita, biotita e clorita, refletindo uma maior proporção de fração argilosa rica em alumínio.

Por outro lado, no diagrama de Herron (1988), observa-se que grande parte das amostras da UBX plotam no campo composicional dos pelitos, com exceção das amostras C325c, C-337 e C-410 que plotam no campo de wacke (figura VI.3). A razão para esta distinção também estaria relacionada com a porcentagem da fração argilosa nos sedimentos, pois as três amostras, mais ricas em $\mathrm{Si}$, apresentam maior proporção de lentes granoblásticas, formadas essencialmente por quartzo, em relação às lentes lepidoblásticas, formadas por muscovita, biotita e clorita.

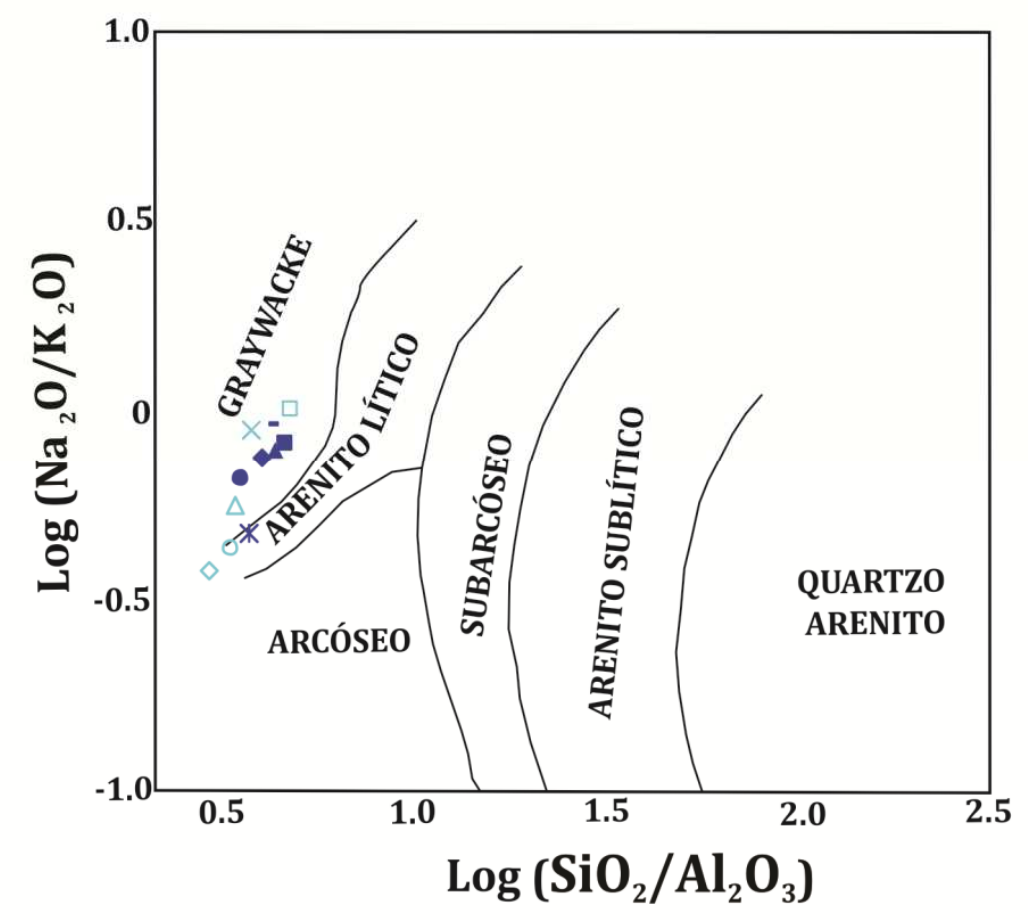

Serra do Pombeiro C- $-411 \triangle \mathrm{C}-430$
$\mathrm{C}-431 \square \mathrm{C}-410 \times$ CAR-I-51 Serra das Bicas

$-\mathrm{C}-325 \mathrm{C} \bullet \mathrm{C}-333 \triangle \mathrm{C}-337$ -C-341 C C-340 * CM-III-25

Figura VI.2: amostra da UBX plotadas no diagrama de classificação química de arenitos segundo Pettijohn et al. (1972). 

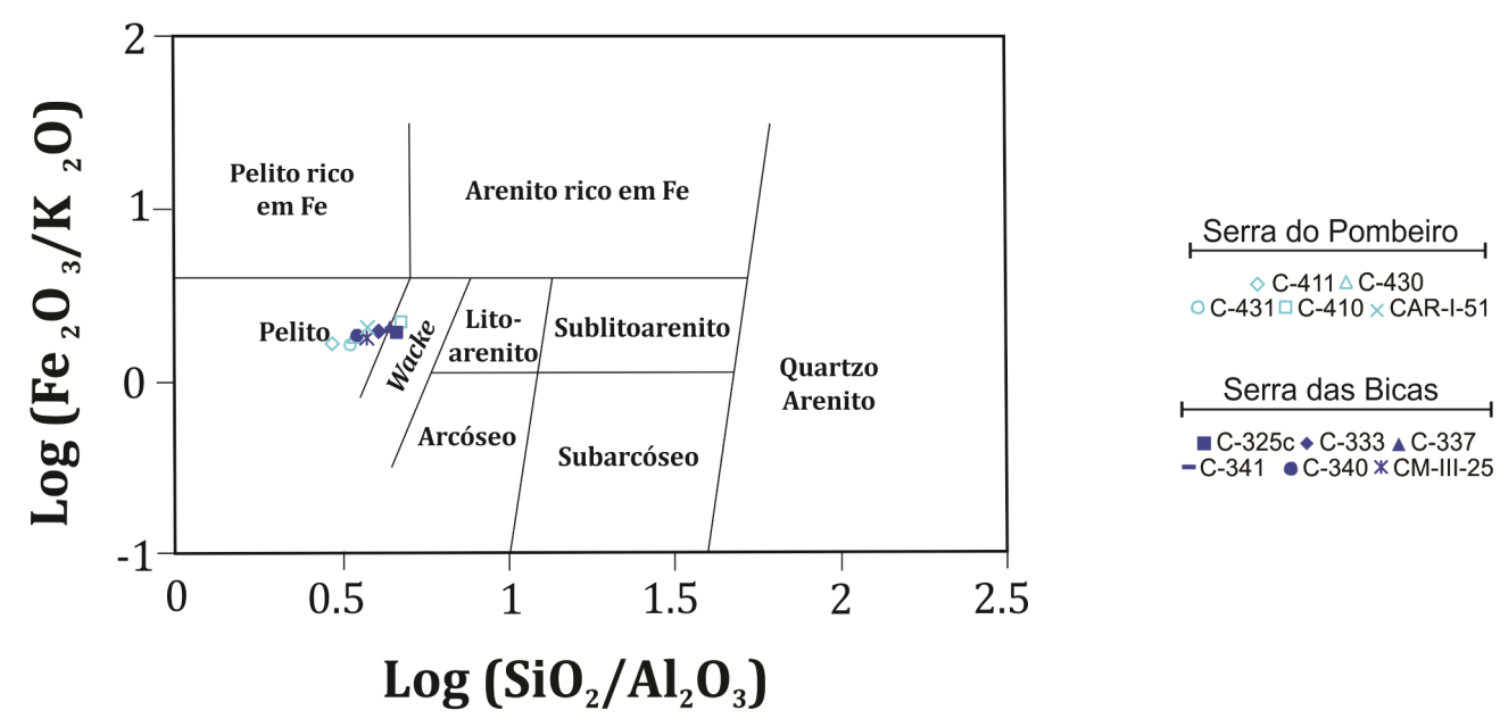

Serra das Bicas

$-\mathrm{C}-341 \bullet \mathrm{C}-340 * \mathrm{CM}-\mathrm{III}-25$

Figura VI.3: amostra da UBX plotadas no diagrama de classificação química de arenitos segundo Herron (1988).

\section{VI.1.2. Chemical Index of Alteration - CIA}

As amostras da UBX apresentaram valores intermediários a altos do CIA, entre 58,41 e 70,26 (tabela VI.3 e figura VI.4). Quanto maior esse índice, maior foi o intemperismo químico da área fonte, ou maior foi a reciclagem dos depósitos sedimentares (Nesbitt e Young, 1982). A predominância de valores intermediários de CIA sugere que os sedimentos precursores das rochas analisadas sofreram intemperismo químico de intensidade e período de tempo moderados, no caso de exposição da área-fonte contemporânea a sedimentação, ou que a área fonte já estaria submetida a um intemperismo químico moderado.

Os valores obtidos foram maiores nas rochas enriquecidas em minerais micáceos $(\mathrm{C}$ 411, CM-III-25) e menores nas amostras com plagioclásio como mineral constituinte (CAR-I51, C-410), ou com maior proporção de porções granoblásticas ricas em quartzo (C-341, C337, C-325c).

Considerando que quanto maior a proporção de fração argilosa, maior a distância relativa da amostra em relação à área-fonte, ou maior o tempo de deposição, os valores de CIA confirmam as correlações entre os elementos químicos observados nos diagramas Harker (amostras enriquecidas em $\mathrm{Al}_{2} \mathrm{O}_{3}$ apresentaram valores de CIA maiores do que as amostras enriquecidas em $\mathrm{SiO}_{2}$ ). 


\begin{tabular}{rcc}
\hline Amostra & CIA \\
\hline C-325c & 60,97 \\
\hline C-333 & 61,37 \\
\hline C-340 & 60,25 \\
\hline C-341 & 63,82 \\
CM-III-25 & 59,03 \\
C-410 & 67,34 \\
C-411 & 62,05 \\
C-430 & 70,26 \\
C-431 & 64,49 \\
CAR-I-51 & 64,19 \\
\hline
\end{tabular}

Tabela VI.3: valores de CIA para as amostras analisadas. CIA $=\left[\mathrm{Al}_{2} \mathrm{O}_{3} /\left(\mathrm{Al}_{2} \mathrm{O}_{3}+\mathrm{CaO}+\mathrm{Na}_{2} \mathrm{O}+\mathrm{K}_{2} \mathrm{O}\right)\right] * 100$; óxidos em proporção molecular.

As concentrações de elementos maiores obtidas também foram plotadas no gráfico ternário $\mathrm{A}\left(\mathrm{Al}_{2} \mathrm{O}_{3}\right)-\mathrm{CN}\left(\mathrm{CaO}+\mathrm{Na}_{2} \mathrm{O}\right)-\mathrm{K}\left(\mathrm{K}_{2} \mathrm{O}\right)$ de avaliação de intensidade de intemperismo (figura VI.6), sugerido por McLennan et al. (1990). As rochas apresentaram uma tendência de intemperismo químico a partir de composições iniciais semelhantes à de andesitos de arcos de ilha. Como a intensidade de alteração, no diagrama, é pouco variável, os sedimentos precursores das amostras analisadas foram submetidos a semelhantes condições intempéricas.

\section{VI.2. Geoquímica de elementos traços}

Os resultados das análises de elementos traço por FRX e ICP-MS são apresentados nas tabelas VI.3 e VI.4 e foram aplicados no estudo de caracterização geoquímica, análise de proveniência e ambientação tectônica. 


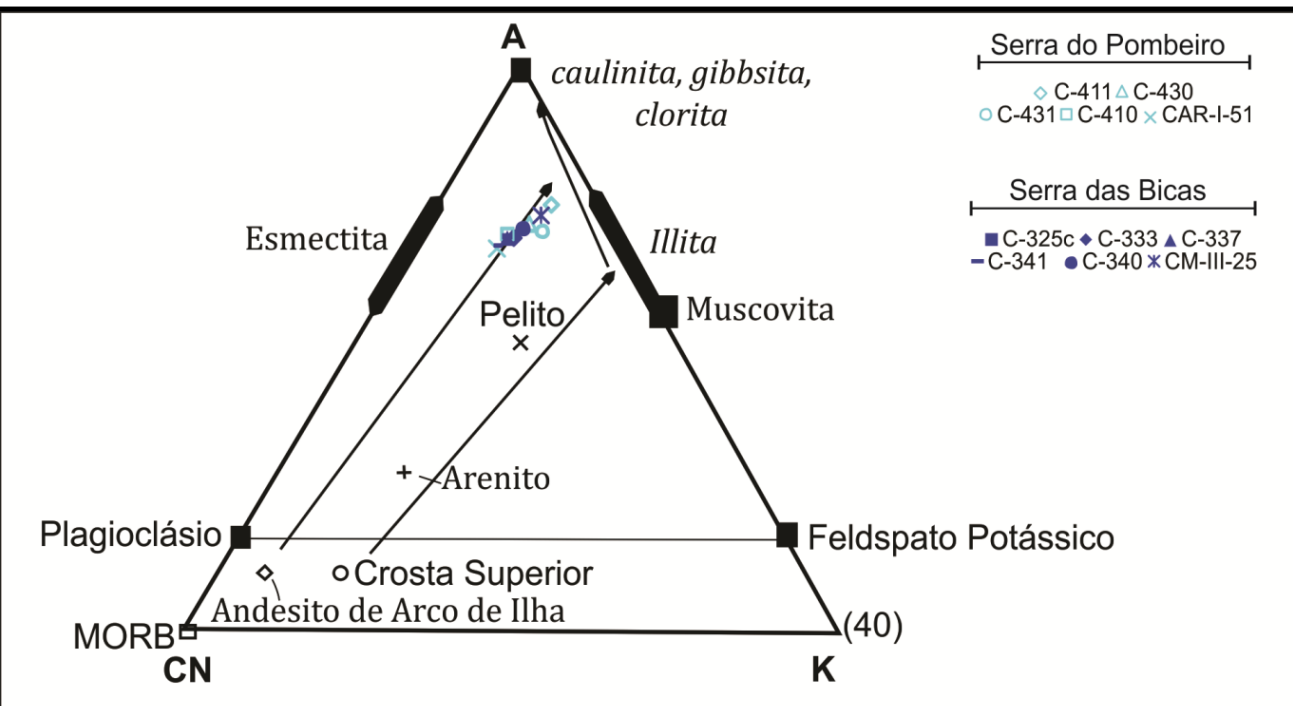

Figura VI.4: amostras analisadas plotadas no diagrama ternário da fração molar de $\mathrm{Al}_{2} \mathrm{O}_{3}(\mathrm{~A})-\mathrm{CaO}+\mathrm{Na}_{2} \mathrm{O}$ em silicatos $(\mathrm{CN})-\mathrm{K}_{2} \mathrm{O}(\mathrm{K})$ extraído, modificado e traduzido de McLennan et al. (1990).

\begin{tabular}{cccccccccccc}
\hline & CAR-I-51 & C-325c & C-333 & C-337 & C-340 & C-341 & CM-III-25 & C-410 & C-411 & C-430 & C-431 \\
Co & 18,3 & 13,1 & 15,6 & 18,2 & 17,3 & 14,2 & 18,4 & 17,1 & 20,4 & 21,3 & 22,9 \\
$\mathbf{C r}$ & 101,6 & 81,1 & 88,0 & 87,1 & 97,4 & 89,5 & 89,4 & 77,4 & 107,5 & 100,4 & 96,0 \\
$\mathbf{C u}$ & 12,2 & 36,4 & 15,8 & 34,6 & 23,9 & 30,3 & 30,7 & 23,5 & 37,2 & 29,2 & 28,7 \\
$\mathbf{G a}$ & 21,2 & 18,5 & 20,9 & 19,4 & 23,9 & 20,7 & 25,0 & 17,8 & 28,9 & 24,8 & 24,5 \\
$\mathbf{N i}$ & 42,1 & 36,2 & 37,4 & 43,1 & 47,2 & 38,6 & 43,5 & 39,9 & 54,1 & 46,9 & 53,0 \\
$\mathbf{R b}$ & 137,3 & 121,8 & 142,4 & 134,5 & 154,5 & 125,9 & 161,7 & 124,7 & 184,4 & 157,6 & 192,1 \\
$\mathbf{S c}$ & 16,6 & $<14$ & 15,2 & 13,7 & 15,3 & 15,1 & 14,6 & 11,1 & 18,3 & 16,8 & 17,0 \\
$\mathbf{V}$ & 120,5 & 89,5 & 113,7 & 103,1 & 124,3 & 110,6 & 120,2 & 88,7 & 143,2 & 143,4 & 146,5 \\
$\mathbf{Z r}$ & 212,5 & 214,2 & 180,2 & 191,1 & 192,4 & 190,6 & 160,9 & 194,8 & 185,6 & 189,5 & 197,0 \\
\hline
\end{tabular}

Tabela VI.3: análises de elementos traço obtidas por FRX para as amostras da unidade UBX (valores em ppm).

O diagrama spider, normalizado segundo a composição média da crosta superior de Taylor e McLennan (1995), apresentado na figura VI.5 mostra que as amostras da unidade UBX são caracterizadas por anomalias negativas de $\mathrm{Sr}$ e subordinadamente de $\mathrm{Ba}$ e enriquecidas em $\mathrm{Cs}$, Th, $\mathrm{Rb}, \mathrm{La}, \mathrm{Ce}, \mathrm{Nd}$ e $\mathrm{Sm}$, sobretudo para aquelas coletadas no alóctone a sul da Serra do Pombeiro. As amostras C-411 e CM-III-25 são as mais empobrecidas em Sr, enquanto a amostras CAR-I-51 é a mais enriquecida neste elemento. 
As amostras C-333, C-337 e C-340, todas coletadas sob a Nappe Carrancas, a leste da Serra das Bicas, são as que apresentam as maiores anomalias negativas de $\mathrm{Ba}$ e leve empobrecimento em La, Ce, Nd e Sm.

Observa-se também, que amostras deste domínio (C-333, C-337 e C-341) têm valores totais de ETR menores e que os maiores valores totais de ETR, ETRL e ETRP são de amostras do alóctone a sul da Serra do Pombeiro (C-411 e C-430).

Os elementos alcalinos e alcalinos terrosos são solubilizados durante intemperismo, com exceção de $\mathrm{Rb}$, Cs e Ba que apresentam maior raio iônico e são retidos em argilominerais durante o intemperismo (Taylor e McLennan, 1985), comportando-se como elementos imóveis durante os processos sedimentares. Diagramas de $\mathrm{Al}_{2} \mathrm{O}_{3}$ vs. $\mathrm{Rb}$, Cs e $\mathrm{Ba}$ (figura VI.6) mostram que estes elementos traço correlacionam-se positivamente com óxido de alumínio, confirmando a tendência de sua concentração em argilo-minerais.

Por outro lado, elementos como Zr e Hf, apesar não serem afetados pelo intemperismo químico são fortemente fracionados durante a sedimentação, pois tendem a se concentrar em minerais pesados, como zircão, depositados em frações arenosas. Diagramas Harker de Zr e Hf (figura VI.7) demonstram a correlação positiva entre estes elementos traço e $\mathrm{SiO}_{2}$, sugerindo que houve perda de zircão durante a sedimentação por processos mecânicos de fracionamento.

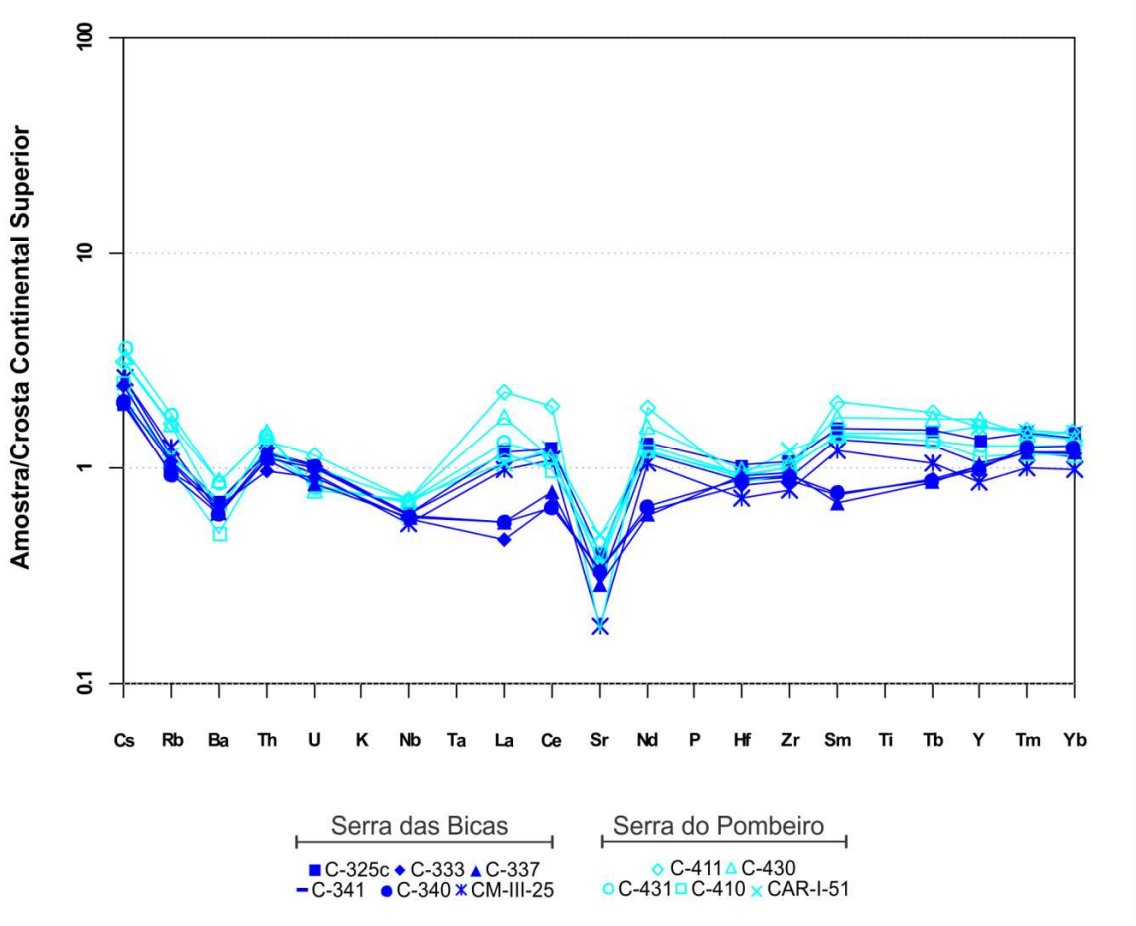

Figura VI.5: diagrama spider de elementos traços normalizados segundo valores para crosta continental superior de Taylor e McLennan (1995) para as amostras da UBX. 


\begin{tabular}{|c|c|c|c|c|c|c|c|c|c|c|c|}
\hline & $\begin{array}{l}\text { CAR- } \\
\text { I- } 51\end{array}$ & $\begin{array}{c}\mathrm{C}- \\
325 \mathrm{c}\end{array}$ & C-333 & C-337 & C-340 & C-341 & $\begin{array}{l}\text { CM- } \\
\text { III-25 }\end{array}$ & C- 410 & C-411 & C- 430 & C-431 \\
\hline $\mathrm{Sr}$ & 165,9 & 139,1 & 116,9 & 100,8 & 101,3 & 116,7 & 64,1 & 140,0 & 60,8 & 115,5 & 123,7 \\
\hline Y & 34,1 & 29,8 & 22,1 & 22,3 & 23,1 & 21,6 & 18,9 & 24,8 & 34,2 & 34,0 & 27,9 \\
\hline $\mathrm{Nb}$ & 17,8 & 15,2 & 14,4 & 14,6 & 15,2 & 14,9 & 13,8 & 17,2 & 17,7 & 16,3 & 17,4 \\
\hline Cs & 7,4 & 7,3 & 8,9 & 7,8 & 9,8 & 7,5 & 9,8 & 9,2 & 11,5 & 10,9 & 13,6 \\
\hline $\mathrm{Ba}$ & 378,7 & 383,0 & 361,8 & 340,4 & 383,6 & 336,3 & 340,9 & 272,2 & 348,1 & 430,0 & 469,0 \\
\hline $\mathrm{La}$ & 31,6 & 35,6 & 13,9 & 16,8 & 31,4 & 16,7 & 29,5 & 34,8 & 67,7 & 47,6 & 39,3 \\
\hline $\mathrm{Ce}$ & 77,6 & 78,6 & 42,9 & 49,4 & 76,0 & 41,7 & 70,0 & 62,8 & 125,0 & 65,2 & 71,6 \\
\hline $\operatorname{Pr}$ & 8,0 & 8,7 & 4,2 & 3,9 & 7,7 & 4,5 & 6,9 & 8,3 & 13,1 & 9,9 & 8,8 \\
\hline $\mathrm{Nd}$ & 31,0 & 33,8 & 16,4 & 15,5 & 30,0 & 17,1 & 27,1 & 31,3 & 49,5 & 37,3 & 33,2 \\
\hline Sm & 6,5 & 6,9 & 3,3 & 3,1 & 6,1 & 3,4 & 5,4 & 6,3 & 9,2 & 7,1 & 6,5 \\
\hline $\mathrm{Eu}$ & 1,4 & 1,4 & 0,8 & 0,8 & 1,2 & 0,8 & 1,0 & 1,3 & 1,9 & 1,4 & 1,3 \\
\hline $\mathrm{Gd}$ & 5,7 & 6,1 & 3,0 & 3,0 & 5,1 & 2,9 & 4,4 & 5,4 & 8,0 & 6,5 & 5,6 \\
\hline $\mathrm{Tb}$ & 0,9 & 1,0 & 0,6 & 0,5 & 0,8 & 0,6 & 0,7 & 0,8 & 1,2 & 1,0 & 0,9 \\
\hline Dy & 5,3 & 5,5 & 3,8 & 3,6 & 4,6 & 3,8 & 3,8 & 4,8 & 6,2 & 5,7 & 4,9 \\
\hline Ho & 1,1 & 1,2 & 0,9 & 0,9 & 1,0 & 0,9 & 0,8 & 1,0 & 1,2 & 1,2 & 1,0 \\
\hline Er & 3,2 & 3,2 & 2,4 & 2,5 & 2,6 & 2,5 & 2,1 & 2,6 & 3,4 & 3,2 & 2,8 \\
\hline $\mathrm{Tm}$ & 0,5 & 0,5 & 0,4 & 0,4 & 0,4 & 0,4 & 0,3 & 0,4 & 0,5 & 0,4 & 0,4 \\
\hline $\mathrm{Yb}$ & 3,2 & 3,0 & 2,5 & 2,6 & 2,5 & 2,8 & 2,2 & 2,5 & 3,2 & 2,7 & 2,8 \\
\hline $\mathrm{Lu}$ & 0,5 & 0,4 & 0,4 & 0,4 & 0,3 & 0,4 & 0,3 & 0,4 & 0,5 & 0,4 & 0,4 \\
\hline $\mathrm{Hf}$ & 5,4 & 5,9 & 4,8 & 5,3 & 5,1 & 5,1 & 4,2 & 5,2 & 5,0 & 5,2 & 5,4 \\
\hline $\mathrm{Pb}$ & 17,9 & 19,0 & 18,8 & 19,6 & 19,4 & 18,8 & 19,1 & 18,6 & 14,9 & 21,8 & 24,1 \\
\hline Th & 12,8 & 12,5 & 10,4 & 11,7 & 12,7 & 11,8 & 12,1 & 12,6 & 14,3 & 14,1 & 15,2 \\
\hline U & 2,8 & 2,9 & 2,5 & 2,4 & 2,9 & 2,8 & 2,6 & 2,3 & 3,2 & 2,0 & 2,3 \\
\hline $\mathrm{Ba}_{\mathrm{N}}$ & 75,10 & 70,93 & 66,75 & 75,21 & 65,95 & 66,84 & 53,37 & 68,25 & 84,31 & 91,96 & 74,25 \\
\hline $\mathrm{La}_{\mathrm{N}}$ & 64,73 & 25,28 & 30,46 & 57,03 & 30,39 & 53,63 & 63,18 & 122,91 & 86,41 & 71,33 & 57,46 \\
\hline $\mathrm{Ce}_{\mathrm{N}}$ & 54,78 & 29,85 & 34,38 & 52,94 & 29,02 & 48,73 & 43,77 & 87,10 & 45,45 & 49,87 & 54,05 \\
\hline $\operatorname{Pr}_{N}$ & 42,19 & 20,62 & 19,11 & 37,25 & 21,75 & 33,82 & 40,19 & 63,54 & 48,42 & 43,02 & 39,17 \\
\hline $\mathrm{Nd}_{\mathrm{N}}$ & 31,70 & 15,34 & 14,51 & 28,13 & 16,05 & 25,42 & 29,34 & 46,44 & 34,94 & 31,10 & 29,06 \\
\hline $\mathrm{Sm}_{\mathrm{N}}$ & 19,84 & 9,67 & 8,95 & 17,70 & 9,93 & 15,71 & 18,21 & 26,48 & 20,44 & 18,62 & 18,80 \\
\hline$E u_{N}$ & 10,95 & 5,82 & 5,82 & 9,23 & 6,20 & 8,03 & 10,09 & 14,56 & 10,85 & 10,04 & 10,85 \\
\hline $\mathrm{Gd}_{\mathrm{N}}$ & 13,26 & 6,49 & 6,57 & 11,13 & 6,26 & 9,61 & 11,76 & 17,42 & 14,16 & 12,17 & 12,41 \\
\hline $\mathrm{Tb}_{\mathrm{N}}$ & 11,04 & 6,53 & 6,26 & 9,28 & 6,38 & 7,72 & 9,76 & 13,22 & 11,46 & 9,81 & 10,60 \\
\hline $\mathrm{Dy}_{\mathrm{N}}$ & 9,70 & 6,59 & 6,34 & 8,04 & 6,62 & 6,57 & 8,41 & 10,90 & 9,99 & 8,66 & 9,26 \\
\hline $\mathrm{Ho}_{\mathrm{N}}$ & 9,45 & 6,89 & 6,94 & 7,97 & 6,97 & 6,14 & 7,55 & 9,65 & 9,09 & 7,95 & 8,86 \\
\hline $\mathrm{Er}_{\mathrm{N}}$ & 8,50 & 6,53 & 6,58 & 6,97 & 6,81 & 5,75 & 7,05 & 9,21 & 8,49 & 7,53 & 8,46 \\
\hline $\mathrm{Tm}_{\mathrm{N}}$ & 8,92 & 7,30 & 7,31 & 7,28 & 7,65 & 6,21 & 7,21 & 9,25 & 8,14 & 7,79 & 9,01 \\
\hline $\mathrm{Yb}_{\mathrm{N}}$ & 8,18 & 6,85 & 6,97 & 6,66 & 7,44 & 5,84 & 6,72 & 8,60 & 7,36 & 7,45 & 8,51 \\
\hline $\mathrm{Lu}_{\mathrm{N}}$ & 7,71 & 6,36 & 6,59 & 6,06 & 7,03 & 5,36 & 6,15 & 8,12 & 6,85 & 6,86 & 8,15 \\
\hline $\mathrm{Eu}_{N} / \mathrm{Eu}^{*}$ & 0,68 & 0,73 & 0,76 & 0,66 & 0,79 & 0,65 & 0,69 & 0,68 & 0,64 & 0,67 & 0,71 \\
\hline $\mathrm{La}_{\mathrm{N}} / \mathrm{Yb}_{\mathrm{N}}$ & 7,91 & 3,69 & 4,37 & 8,56 & 4,08 & 9,19 & 9,40 & 14,29 & 11,73 & 9,57 & 6,75 \\
\hline $\mathrm{La}_{\mathrm{N}} / \mathrm{Sm}_{\mathrm{N}}$ & 3,26 & 2,61 & 3,40 & 3,22 & 3,06 & 3,41 & 3,47 & 4,64 & 4,23 & 3,83 & 3,06 \\
\hline $\mathrm{Gd}_{N} / \mathrm{Yb}_{\mathrm{N}}$ & 1,62 & 0,95 & 0,94 & 1,67 & 0,84 & 1,65 & 1,75 & 2,03 & 1,92 & 1,63 & 1,46 \\
\hline
\end{tabular}

Tabela VI.4: análises de elementos traço obtidas por LA-ICP MS para a unidade UBX (valores em ppm). Elementos Terras Raras condrito-normalizados segundo Taylor \& McLennan (1985). Eu* $=\left[\left(\operatorname{Sm}_{N}\right)\left(\operatorname{Gd}_{\mathrm{N}}\right)\right]^{1 / 2}$. 


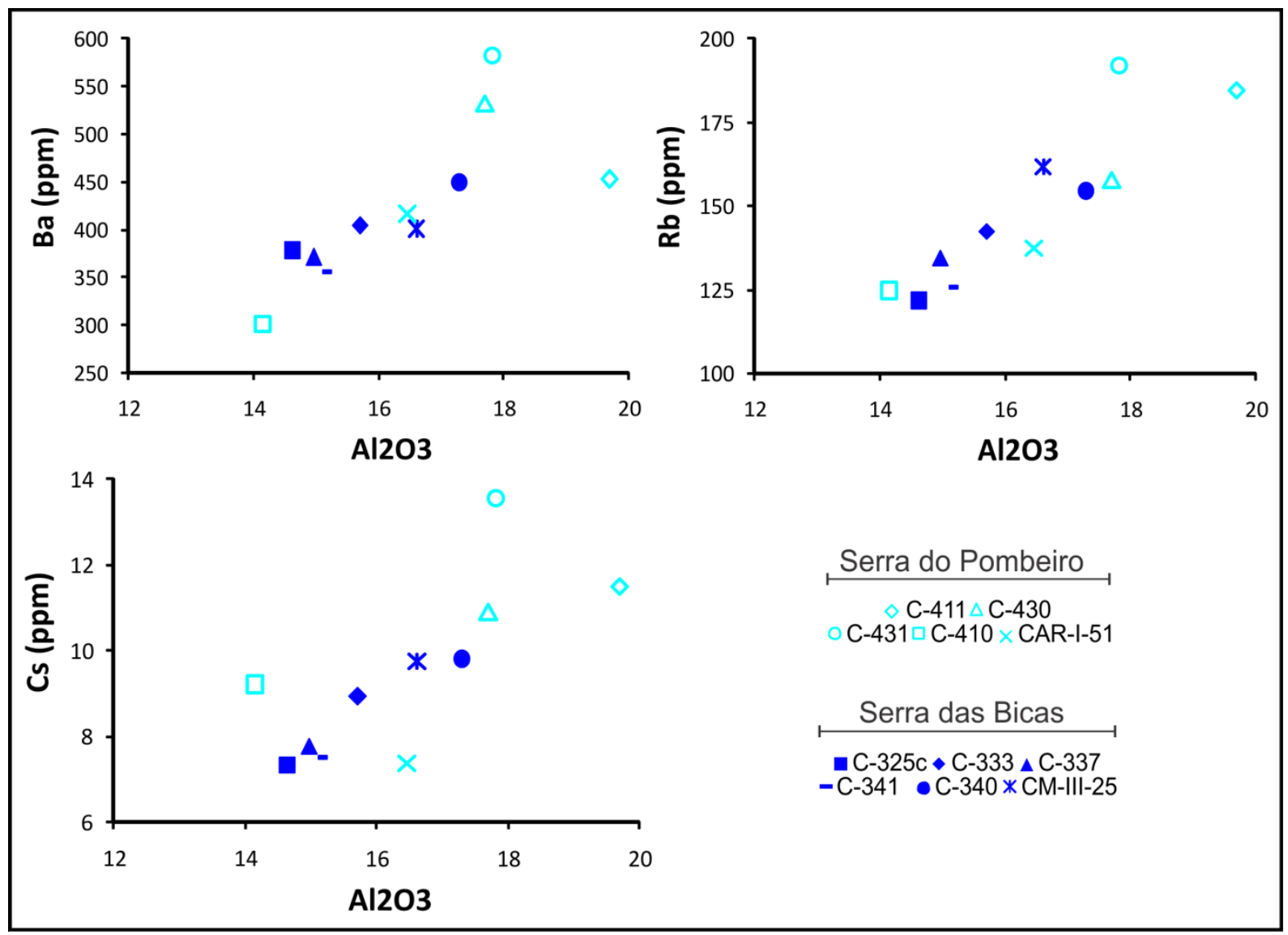

Figura VI.6: diagramas de $\mathrm{Al}_{2} \mathrm{O}_{3}$ vs. $\mathrm{Rb}$, Cs e $\mathrm{Ba}$ para as amostras da UBX. Observar a correlação positiva entre os elementos.

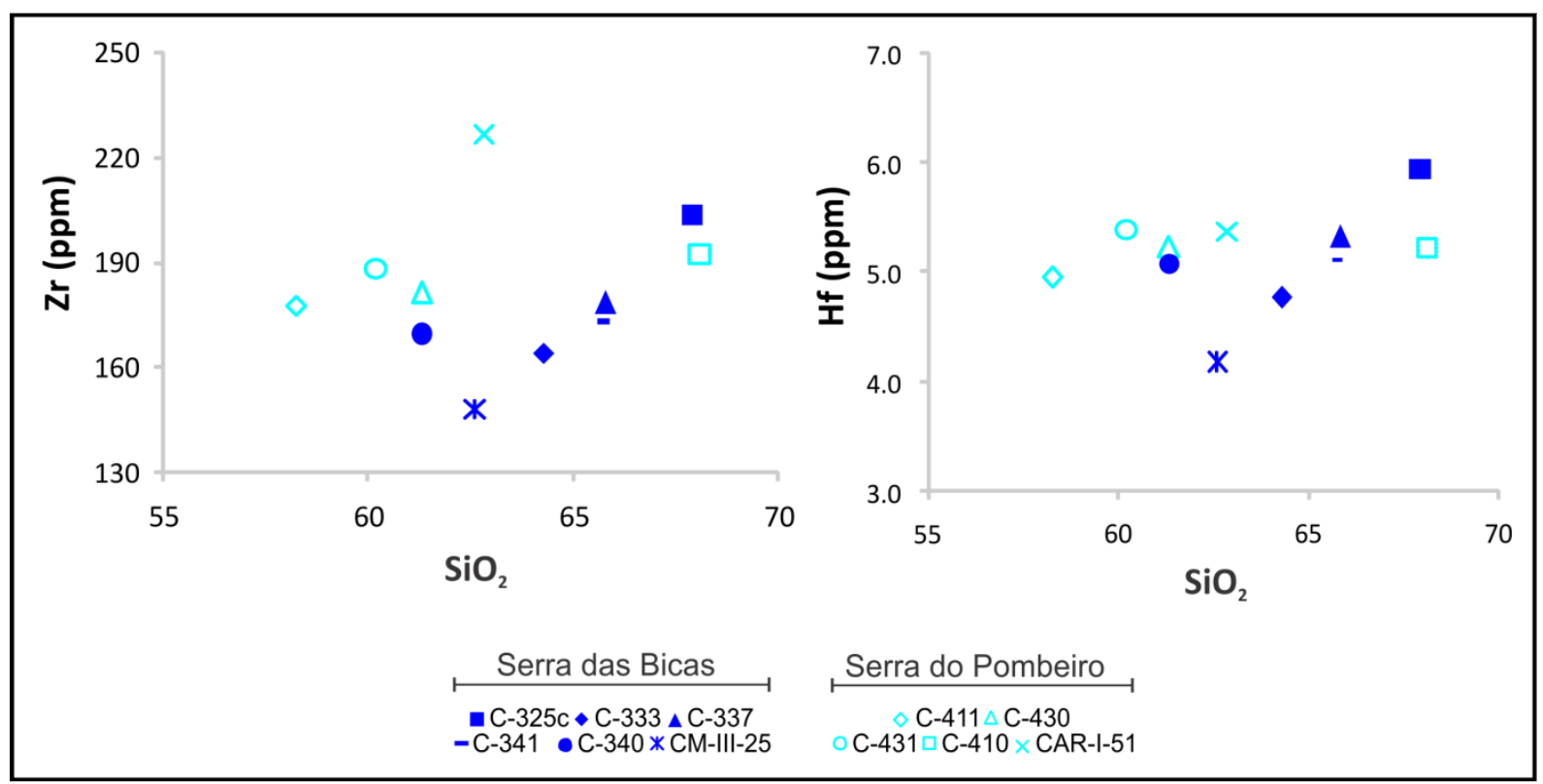

Figura VI.7: diagramas Harker de Zr e Hf que mostram a correlação positiva entre os elementos. 


\section{VI.2.1. Elementos Terras Raras (ETR)}

As amostras apresentam padrões de ETR típicos de rochas sedimentares pós-arqueanas (McLennan et al., 1990) com enriquecimento de ETRL, padrões relativamente constantes de ETRP e anomalias negativas de Eu (figura VI.8).

Rochas coletadas no alóctone a sul da Serra do Pombeiro tendem a apresentar maiores valores de fracionamento de ETR (média de 10,35), ETRL (média de 3,84), ETRP (média de 1,76) e maiores anomalias negativas de Eu (média de 0,68). Por outro lado, as rochas coletadas na região nordeste da Serra das Bicas apresentam valores menores do que as da Serra do Pombeiro, com média de $\mathrm{La}_{N} / \mathrm{Yb}_{\mathrm{N}}=6,30$, média de $\mathrm{La}_{\mathrm{N}} / \mathrm{Sm}_{\mathrm{N}}=3,16$, média de $\mathrm{Gd}_{\mathrm{N}} / \mathrm{Yb}_{\mathrm{N}}=1,28$ e anomalias negativas de Eu com valor médio de 0,71, Entretanto, apesar das diferenças é possível separar as amostras segundo três assinaturas distintas:

(i) Amostra C-411 (alóctone a sul da Serra do Pombeiro): maiores valores totais de ETR $(\Sigma E T R=515,65)$ com forte fracionamento de ETR $\left(\mathrm{La}_{N} / \mathrm{Yb}_{\mathrm{N}}=14,29\right), \mathrm{ETRL}\left(\mathrm{La}_{N} / \mathrm{Sm}_{\mathrm{N}}\right.$ $=4,64)$ e ETRP $\left(\mathrm{Gd}_{\mathrm{N}} / \mathrm{Yb}_{\mathrm{N}}=2,03\right)$. Anomalia de Eu é intermediária $\left(\mathrm{Eu}_{\mathrm{N}} / \mathrm{Eu}^{*}=0,68\right)$;

(ii) Amostras C-333, C-337 e C-341 (leste da Serra das Bicas): menores valores totais de ETR ( $\Sigma$ ETR entre 231,06 e 234,04), com menores fracionamentos de ETR $\left(\mathrm{La}_{N} / \mathrm{Yb}_{\mathrm{N}}\right.$ entre 3,69 e 4,37), ETRL $\left(\mathrm{La}_{N} / \mathrm{Sm}_{\mathrm{N}}\right.$ entre 2,61 e 3,40) e ETRP $\left(\mathrm{Gd}_{\mathrm{N}} / \mathrm{Yb}_{\mathrm{N}}\right.$ entre 0,84 e 0,95). Anomalias negativas de Eu também são as menores $\left(\mathrm{Eu}_{N} / \mathrm{Eu}^{*}\right.$ entre 0,73 e 0,79);

(iii) Demais amostras: valores totais de ETR intermediários ( $\Sigma$ ETR entre 305,88 e 406,36) com $\mathrm{La}_{\mathrm{N}} / \mathrm{Yb}_{\mathrm{N}}$ entre 6,75 e 11,73, $\mathrm{La}_{\mathrm{N}} / \mathrm{Sm}_{\mathrm{N}}$ entre 3,22 e 4,23, $\mathrm{Gd}_{\mathrm{N}} / \mathrm{Yb}_{\mathrm{N}}$ entre 1,46 e 1,92 e $\mathrm{Eu}_{\mathrm{N}} / \mathrm{Eu}^{*}$ entre 0,64 e 0,71 Neste grupo, a amostra CAR-I-51 apresenta os menores valores de fracionamento de ETR, ETRL, ETRP e de anomalia negativa de Eu. Por outro lado, a amostra C-430 tem os maiores valores de fracionamento de ETR, ETRL, ETRP e de anomalia negativa de Eu.

As amostras do grupo (iii) são as que mais se assemelham às composições médias de pelitos do pós-Arqueano da Austrália (PAAS) e da América do Norte (NASC) definidos por Nance e Taylor (1976) e Haskin (1968), respectivamente.

A amostra C-411 tem um maior valor total de ETRL, enquanto as amostras do grupo (ii) têm valores menores que os padrões médios para os mesmos elementos.

As anomalias negativas de Eu são $\left(\mathrm{Eu}_{\mathrm{N}} / \mathrm{Eu}^{*}=0,64-0,79\right)$, compatíveis com o valor médio da crosta continental superior (Taylor e McLennan, 1985; McLennan et al., 1990). Estes valores combinados com baixos valores de fracionamento de ETRP (figura VI.9) sugerem área-fonte com rochas ígneas geradas a partir de fracionamento químico intracrosta 
durante a evolução magmática foram a principal fonte dos sedimentos da Unidade Biotita Xisto (McLennan et al., 1990; McLennan e Taylor, 1991; Taylor e McLennan, 1985 e 1995). O empobrecimento em Sr observado na figura VI.5 sugere que o fracionamento químico intracrosta ocorreu principalmente em presença de plagioclásio rico em $\mathrm{Ca}$, pois $\mathrm{Eu}^{2+}$ substitui $\mathrm{Sr}^{2+}$ neste mineral ocasionando as anomalias negativas de ambos elementos químicos no líquido residual (McLennan e Taylor, 1991).

Segundo Taylor e McLennan (1985), apesar da forma geral dos padrões de ETR serem semelhantes em arenitos e pelitos pós-arqueanos, os primeiros tendem a apresentar menores valores totais de ETR e de $\mathrm{La}_{N} / \mathrm{Yb}_{\mathrm{N}}$ do que os segundos. Considerando essa característica geoquímica, as amostras do grupo (ii) são mais ricas em frações arenosas do que as demais, o que é corroborado pelos menores valores tanto do fracionamento de ETRP, quanto da menor anomalia negativa de Eu. Essas amostras do grupo (ii) encontram-se, no diagrama de classificação química de arenitos de Herron (1988), na fronteira entre os campos dos pelitos e wackes, apesar daquelas, no campo de wackes, encontrarem-se no grupo (iii). A amostra C411, que apresenta maiores valores totais de ETR, encontra-se destacada, no campo dos pelitos no diagrama de Herron (figura VI.3).

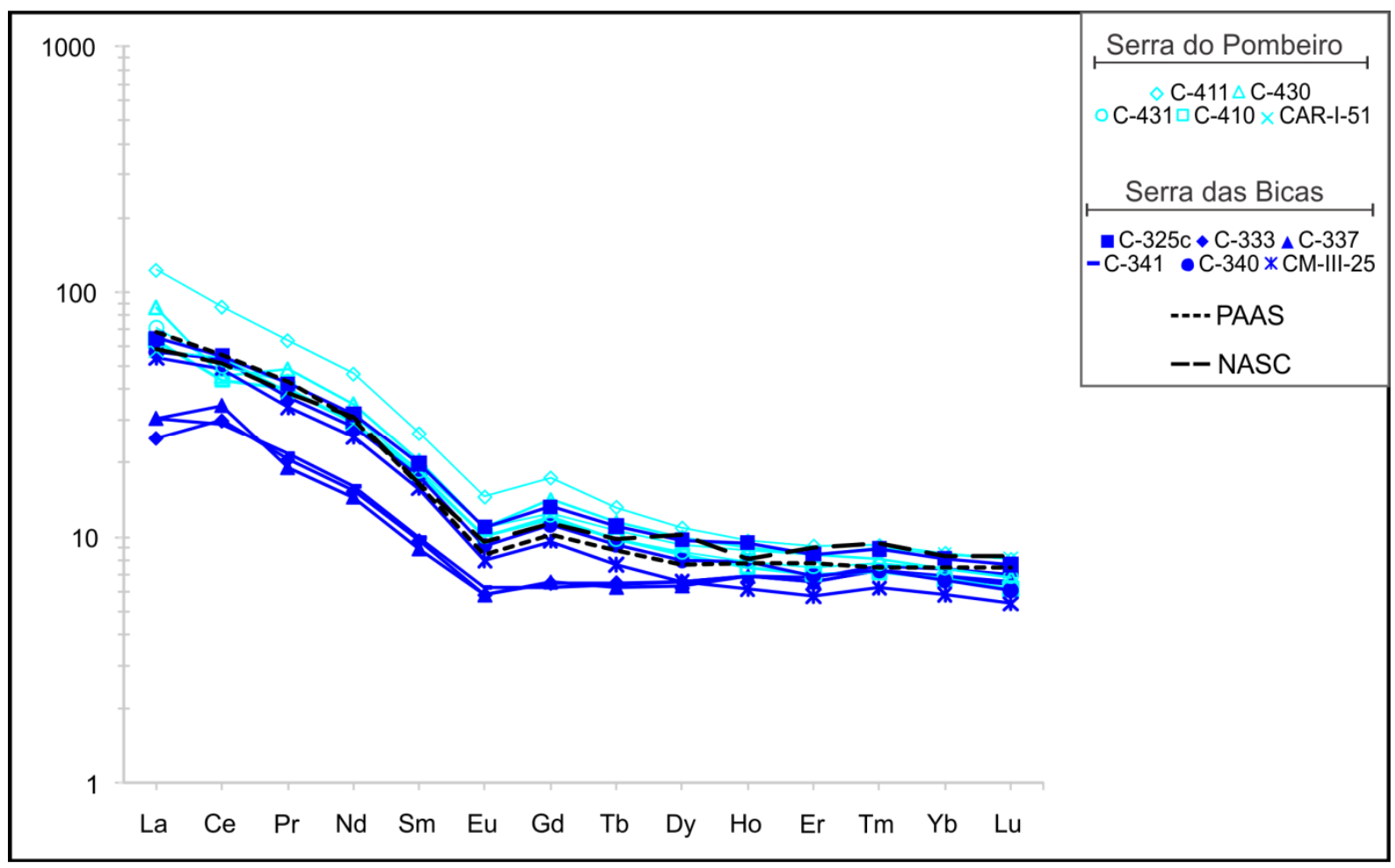

Figura VI.8: Diagrama de Condrito-normalizado (Taylor \& McLennan, 1985) mostrando o padrão de Elementos Terras Raras das amostras da UBX analisadas. Valores médios de pelitos pós-Arqueanos foram plotados para comparação. PAAS: Post-Archean Australian Shale (Nance e Taylor, 1976); NASC: North American Shale Composite (Haskin, 1968). 


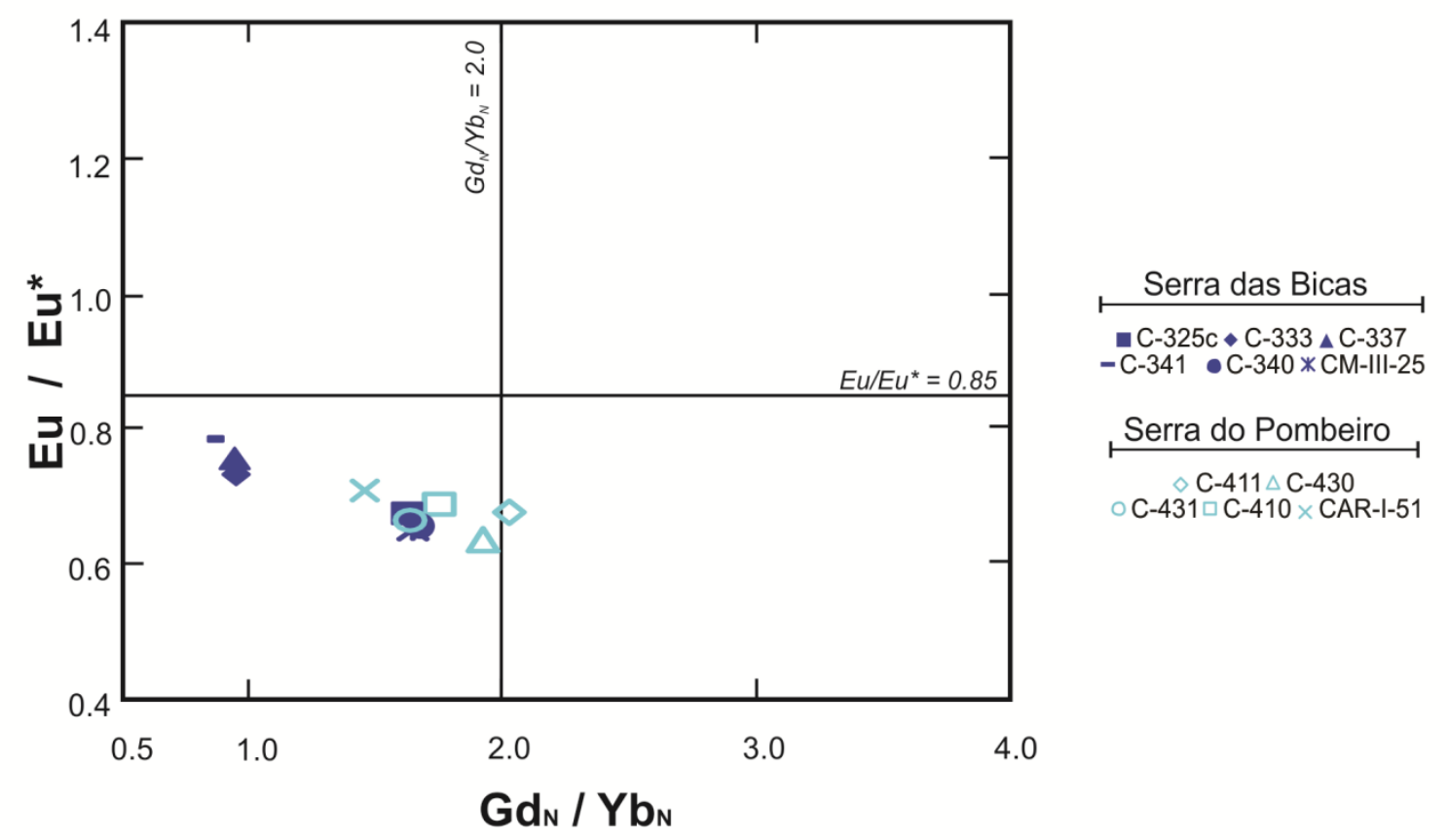

Figura VI.9: gráfico de fracionamento de ETRP $v s$. Anomalia de Eu com as amostras analisadas. Linha Eu/Eu* $=0,85$ : McLennan et al. (1990) considera que cerca de 80\% de amostras sedimentares do Arqueano apresentam $\mathrm{Eu} / \mathrm{Eu}^{*}>0,85$, enquanto nos turbiditos modernos apenas $30 \%$ apresentam valores de anomalia de Eu superiores a este valor; Linha $\mathrm{Gd}_{N} / \mathrm{Yb}_{\mathrm{N}}=2,0$ : os mesmos autores consideram que turbiditos arqueanos apresentam valores maiores do que 2,0 ,

\section{VI.2.2. Razão $T h / S c$}

A razão Th/Sc foi utilizada nestes trabalho com intuito de estabelecer a importância de rochas derivadas de fontes mais evoluídas (félsicas) e de fontes primitivas (máficas) na proveniência das rochas estudadas, pois Th comporta-se como elemento incompatível em sistemas ígneos e Sc é compatível e tende a se concentrar em cristais de piroxênio.

As amostras analisadas apresentam valores da razão $\mathrm{Th} / \mathrm{Sc}$ variáveis e menores do que 1,0 (tabela VI.5), com exceção da amostra C-410, Segundo McLennan et al. (1990) amostras que possuem tais características químicas são oriundas de ambientes tectonicamente ativos e predominantemente máficos, mas como os valores das amostras são sempre próximos a 1,0 eles sugerem que áreas-fonte félsicas exerceram papel importante na proveniência da bacia. 


\begin{tabular}{cccc}
\hline AMOSTRA & Th/Sc & Cr/V & Eu $_{\mathbf{N}} / \mathbf{E u}^{*}$ \\
\hline C-325c & - & 0,91 & 0,68 \\
C-333 & 0,68 & 0,77 & 0,73 \\
C-337 & 0,85 & 0,84 & 0,76 \\
C340 & 0,83 & 0,78 & 0,66 \\
C-341 & 0,78 & 0,81 & 0,79 \\
CM-III-25 & 0,83 & 0,74 & 0,65 \\
C-410 & 1,13 & 0,87 & 0,69 \\
C-411 & 0,78 & 0,75 & 0,68 \\
C-430 & 0,84 & 0,70 & 0,64 \\
C-431 & 0,89 & 0,66 & 0,67 \\
CAR-I-51 & 0,77 & 0,84 & 0,71 \\
\hline
\end{tabular}

Tabela VI.5: valores da razão $\mathrm{Th} / \mathrm{Sc}, \mathrm{Cr} / \mathrm{V}$ e $\mathrm{Eu}_{\mathrm{N}} / \mathrm{Eu}^{*}$ para as amostras da UBX analisadas.

Nos gráficos $\mathrm{Th} / \mathrm{Sc} v$ s. CIA e $\mathrm{Eu} / \mathrm{Eu}^{*}$ vs. CIA (figura VI.10) e na tabela VI.5 observa-se, de uma maneira geral, com exceção da amostra C-337, que as rochas com valores de $\mathrm{Th} / \mathrm{Sc}$ mais próximos de 1.0 (entre 0,83 e 1.13) são aquelas que possuem anomalias de Eu mais negativas e maiores valores de CIA, ao passo que as rochas com valores $\mathrm{Th} / \mathrm{Sc}$ menores (entre 0,68 e 0,78 ) possuem Eu/Eu* menos negativas e menor índice de alteração química. Considerando-se uma mesma área-fonte principal para os sedimentos, as amostras CAR-I-51, C-341, C-337, C-333, C-325c e C-410, pelos menores valores em CIA, relativamente menores valores da razão $\mathrm{Th} / \mathrm{Sc}$ e maiores da razão $\mathrm{Cr} / \mathrm{V}$ e menores anomalias negativas de $\mathrm{Eu}$, sugerem ser oriundas de sedimentos depositados em porções mais próximas à área-fonte, e menos afetadas por processos de intemperismo químico durante a sedimentação. 


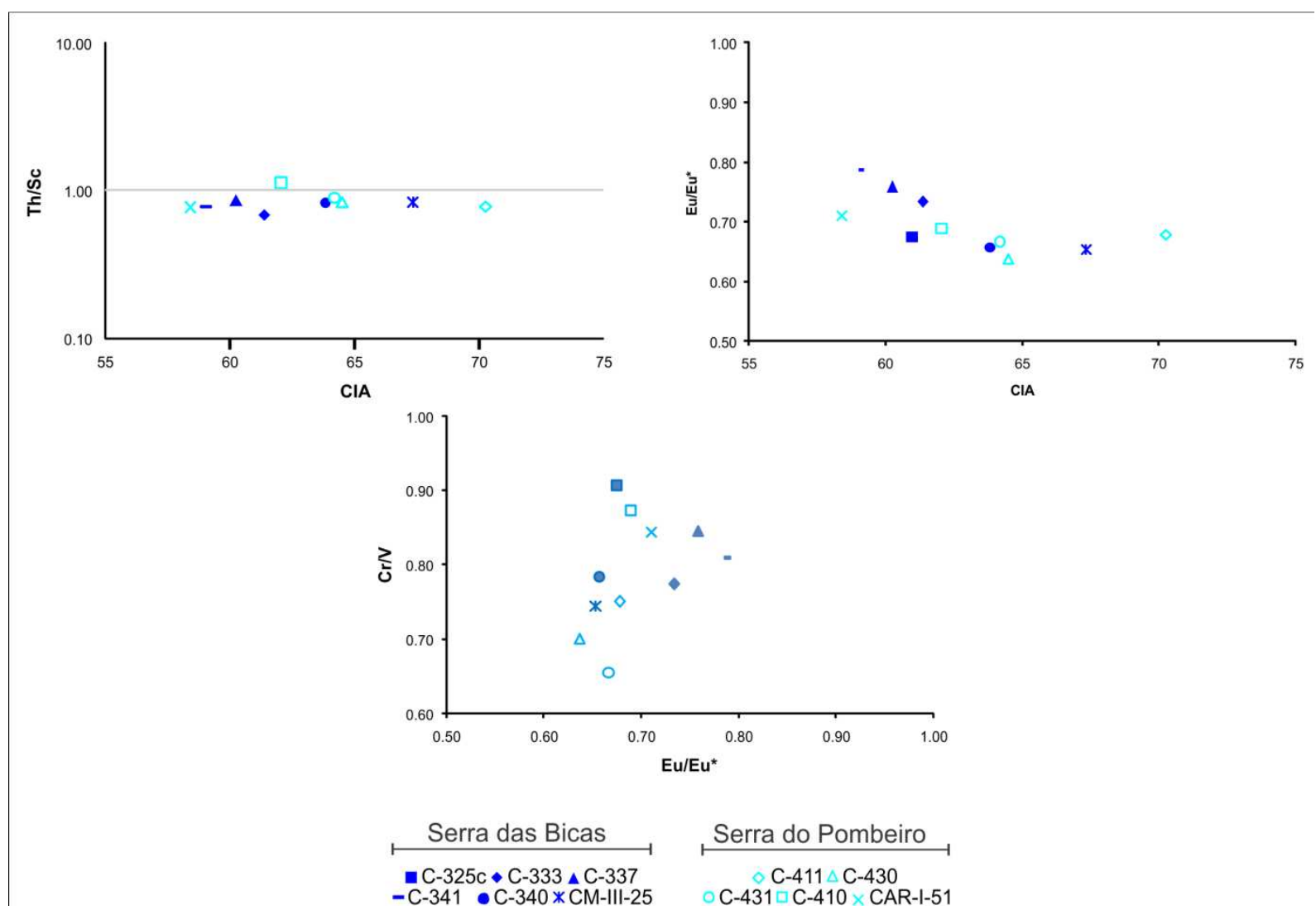

Figura VI.10: Diagramas Th/Sc vs. CIA, Eu/Eu*vs. CIA e Eu/Eu*vs. Cr/V para as amostras da unidade UBX.

McLennan et al. (1993) sugere que altas razões $\mathrm{Cr} / \mathrm{V}$ indicam enriquecimento de $\mathrm{Cr}$ sobre outros elementos traços ferromagnesianos e a contribuição de rochas máficasultramáficas na área-fonte do sedimento, na medida em que o $\mathrm{Cr}$ tende a se concentrar em espinélio, piroxênio e olivina. Por exemplo, séries ofiolíticas apresentam valores $\mathrm{Cr} / \mathrm{V}$ maiores que 8,0 ,

Os valores de $\mathrm{Cr} / \mathrm{V}$ obtidos para as rochas analisadas (tabela VI.5) se mantém sempre abaixo de 1,0, indicando que rochas máficas não foram tão importantes na proveniência dos sedimentos. Entretanto, amostras com menores valores da razão $\mathrm{Cr} / \mathrm{V}$ tendem a apresentar as maiores anomalias negativas de Eu (figura VI.10 e tabela VI.5), confirmando a divisão em dois grupos de amostras, um com maior componente máfico e menos afetado pelo intemperismo químico e outro com maior componente félsico e mais afetado pelo intemperismo químico. 


\section{VI.2.3. Reciclagem sedimentar}

Elementos químicos como Zr e Hf são comumente concentrados em zircão, mineral pesado resistente a processos intempéricos e de reciclagem sedimentar. Maiores valores para a razão $\mathrm{Zr} / \mathrm{Sc}$ e para a concentração de Hf sugerem maior concentração de zircão e, por isso, reciclagem sedimentar mais intensa (McLennan et al., 1993)

Os valores das razões Th/Sc e $\mathrm{Zr} / \mathrm{Sc}$ obtidos para as amostras da unidade UBX (figura VI.11 e tabela VI.6) são semelhantes aos sugeridos por Taylor e McLennan (1985, 1995 e 2001), Condie (1993), Rudnick e Fountain (1995) e Rudnick e Gao (2003) para a crosta continental superior. O mesmo ocorre para os valores obtidos para a concentração de Hf, com exceção da amostra CM-III-25.

As rochas da unidade UBX não sofreram grande influência de processos de reciclagem sedimentar, pois não houve enriquecimento e concentração de minerais pesados, indicado pelos valores intermediários obtidos para a razão $\mathrm{Zr} / \mathrm{Sc}$ e para a concentração de Hf.

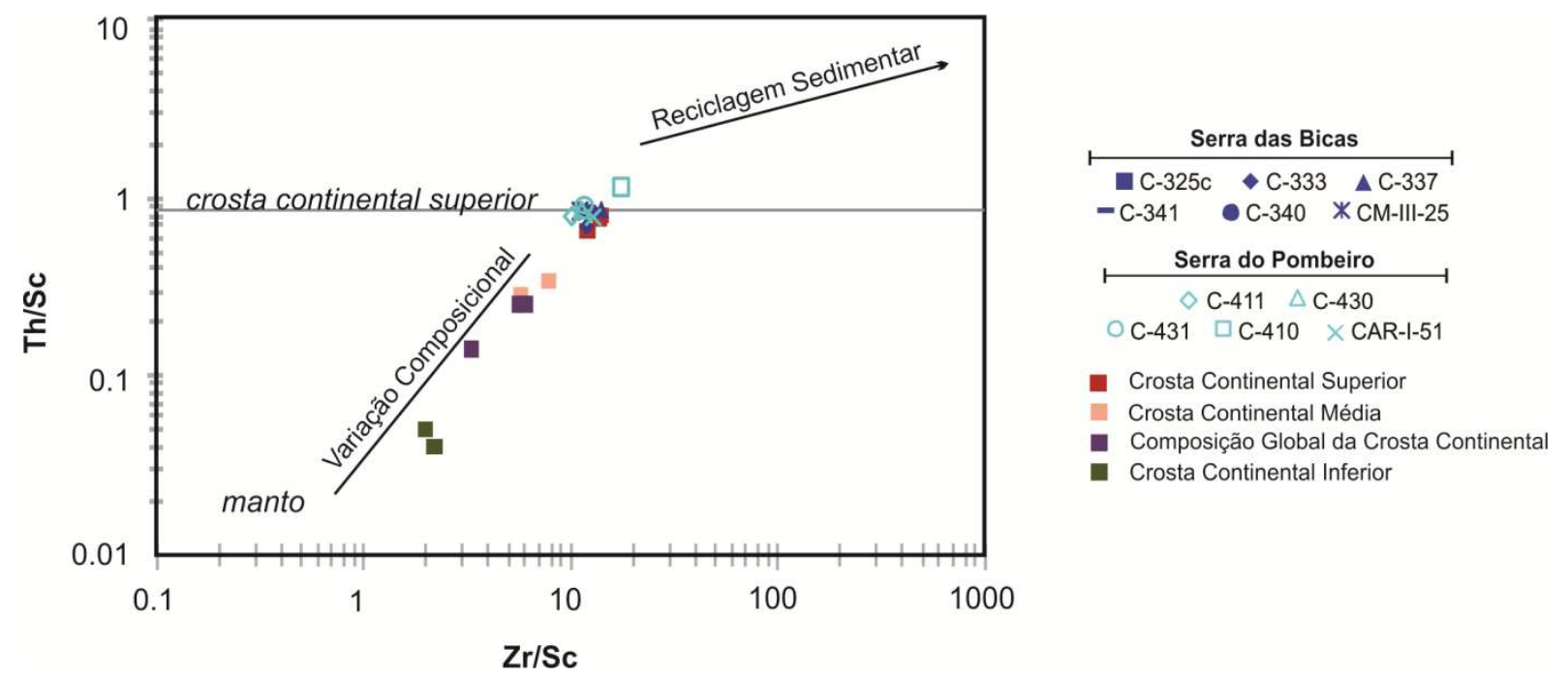

Figura VI.11: gráfico Zr/Sc vs. Th/Sc extraído de McLennan et al. (1993) para as amostras da unidade UBX que mostra a intensidade da reciclagem sedimentar do sedimento e a sua composição em relação às composições do manto e da crosta continental superior. Valores médios para a crosta continental superior, média, inferior e para a composição global da crosta continental sugeridos por Taylor e McLennan (1985, 1995, 2001), Condie (1993), Rudnick e Fountain (1995) e Rudnick e Gao (2003) foram plotados para comparação. 


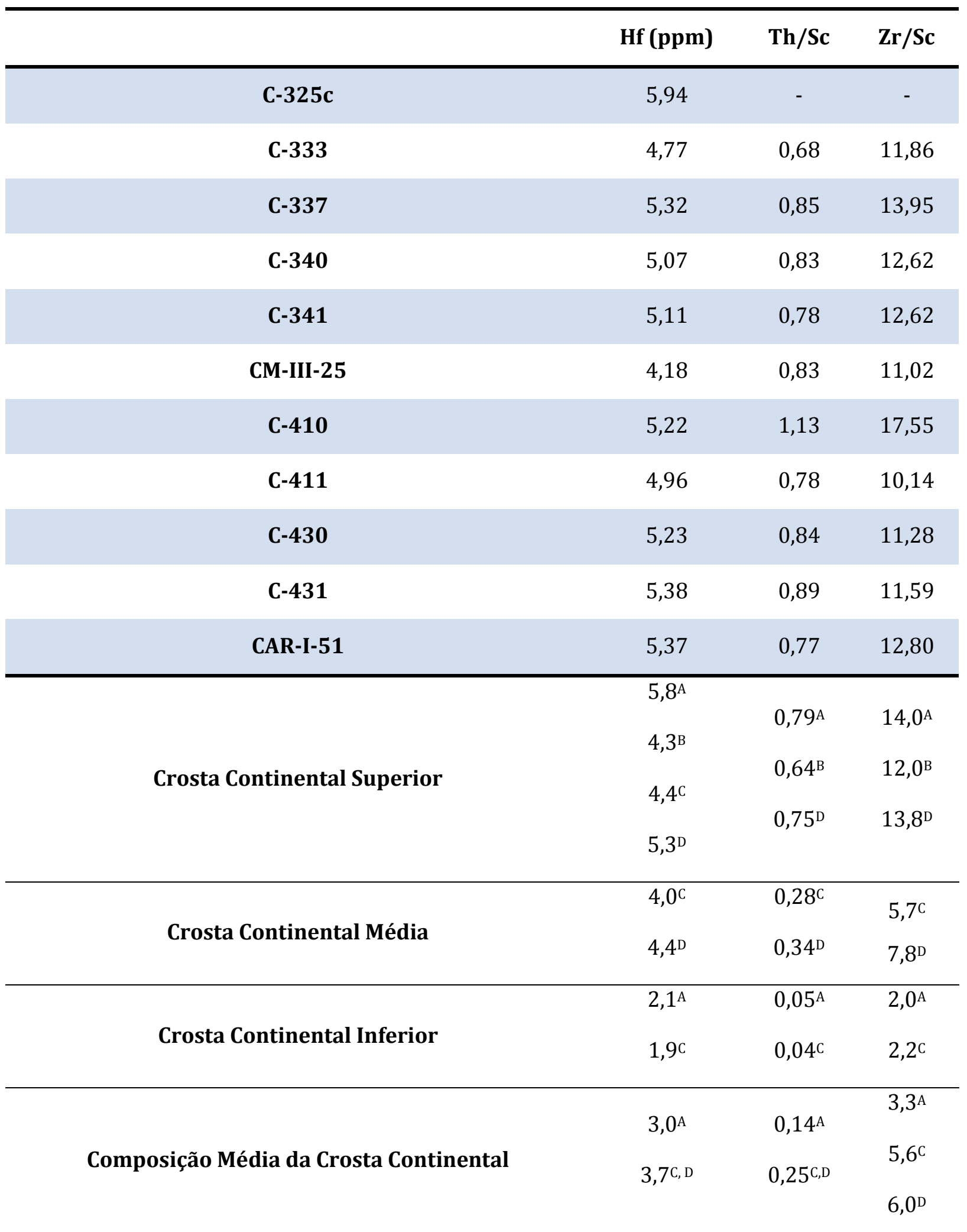

Tabela VI.6: valores das razões La/Sc, Th/Sc e Zr/Sc para as amostras da unidade UBX analisadas e valores de referência para crosta continental superior, média e inferior extraídos da literatura. ${ }^{\text {A}}$ : Taylor e McLennan (1985, 1995, 2001); ${ }^{\text {B }}$ : Condie (1993); ${ }^{\text {C }}$ Rudnick e Fountain (1995); ${ }^{\text {D }}$ : Rudnick e Gao (2003). 


\section{CAPÍTULO VII}

\section{GEOQUÍMICA ISOTÓPICA}

\section{VII.1. Sistema Rb-Sr em rocha total}

As razões iniciais ${ }^{87} \mathrm{Sr}^{86} \mathrm{Sr}_{\mathrm{i}}$ foram calculadas a partir dos dados isotópicos e elementais apresentados na tabela VII.1 e da idades de 590 Ma e 610 Ma referentes às idades de metamorfismo obtidas em cristais de monazita para rochas do Sistema de Nappes Carrancas (Campos Neto et al., 2011) e Sistema de Nappes Andrelândia (Campos Neto et al., 2007).

\begin{tabular}{|c|c|c|c|c|c|c|c|}
\hline Amostra & $\begin{array}{c}\text { Rb } \\
(\mathrm{ppm})\end{array}$ & $\begin{array}{c}\mathrm{Sr} \\
(\mathrm{ppm})\end{array}$ & ${ }^{87} \mathrm{Sr} /{ }^{86} \mathrm{Sr}$ & $\begin{array}{l}\text { erro } \\
(2 \sigma)\end{array}$ & ${ }^{87} \mathrm{Rb} /{ }^{86} \mathrm{Sr}$ & $\begin{array}{l}{ }^{87} \mathrm{Sr} /{ }^{86} \mathrm{Sr}_{\mathrm{i}} \\
(590 \mathrm{Ma})\end{array}$ & $\begin{array}{l}{ }^{87} \mathrm{Sr} /{ }^{86} \mathrm{Sr}_{\mathrm{i}} \\
\text { (610 Ma) }\end{array}$ \\
\hline C-325c & 121,80 & 131,90 & 0,7353 & 0,00007 & 2,48633 & 0,71440 & 0,71369 \\
\hline C-333 & 142,40 & 121,50 & 0,7421 & 0,00008 & 3,15566 & 0,71559 & 0,71468 \\
\hline C-337 & 134,50 & 106,80 & 0,7445 & 0,00009 & 3,39084 & 0,71606 & 0,71509 \\
\hline C-340 & 154,50 & 112,00 & 0,7482 & 0,00007 & 3,71421 & 0,71696 & 0,71589 \\
\hline C-341 & 125,90 & 128,40 & 0,7368 & 0,00007 & 2,64008 & 0,71460 & 0,71385 \\
\hline CM-III-25 & 161,70 & 67,70 & 0,7706 & 0,00005 & 6,43098 & 0,71653 & 0,71469 \\
\hline CAR-I-51 & 137,30 & 168,00 & 0,7325 & 0,00007 & 2,20048 & 0,71399 & 0,71336 \\
\hline
\end{tabular}

Tabela VII.1: dados isotópicos e elementais do sistema Rb-Sr para as amostras da unidade UBX. ${ }^{87} \mathrm{Rb} /{ }^{86} \mathrm{Sr}=$ $\left(\mathrm{Rb}_{\mathrm{ppm}} / \mathrm{Sr}_{\mathrm{ppm}}\right) * 2.8937 * 0,93047 ;{ }^{87} \mathrm{Sr} /{ }^{86} \mathrm{Sr}_{\mathrm{i}}={ }^{87} \mathrm{Sr} /{ }^{86} \mathrm{Sr}-{ }^{87} \mathrm{Rb} /{ }^{86} \mathrm{Sr}(\lambda \mathrm{t})$

As razões ${ }^{87} \mathrm{Sr} /{ }^{86} \mathrm{Sr}_{\mathrm{i}}$ obtidas ficaram entre o intervalo de 0,71399 e 0,71696 para idade de 590 Ma e 0,71336 e 0,71589 para idade de 610 Ma.

A figura VII.1 mostra as a variação de ${ }^{87} \mathrm{Rb} /{ }^{86} \mathrm{Sr}$ e ${ }^{87} \mathrm{Sr} /{ }^{86} \mathrm{Sr}$ para as amostras analisadas. Todas as razões alinham-se próximo à isócrona de referência de idade $630 \pm 44$ Ma e razão inicial 0,7135. Esta idade se aproxima dos valores considerados para o metamorfismo na região da Nappe Socorro-Guaxupé (Campos Neto et al., 2004) e na Nappe de Passos (Valeriano et al., 2004). No entanto, o alto valor de MSWD (565) faz com que a idade obtida seja considerada com muita cautela. 


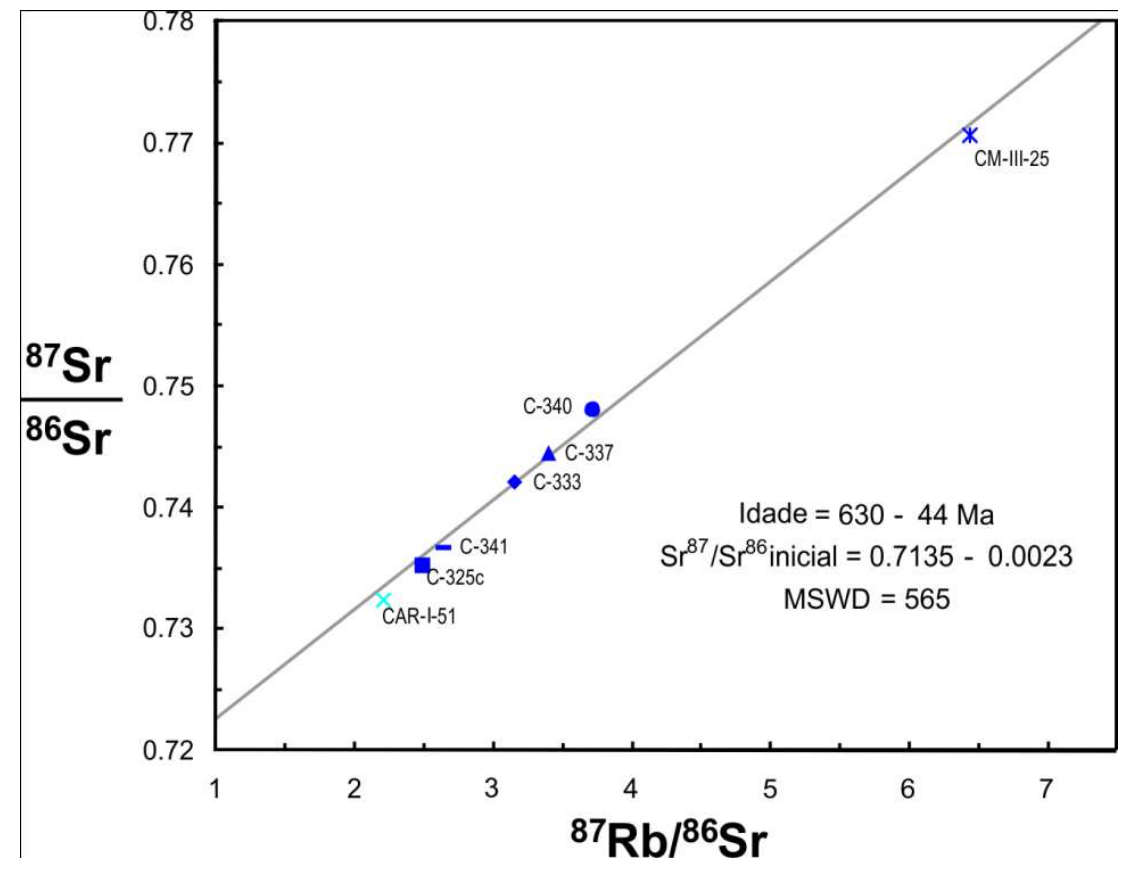

Figura VII.1: Diagrama ${ }^{87} \mathrm{Rb} /{ }^{86} \mathrm{Sr} v s .{ }^{87} \mathrm{Sr} /{ }^{86} \mathrm{Sr}$ para as amostras da unidade UBX.

Menores razões ${ }^{87} \mathrm{Sr} /{ }^{86} \mathrm{Sr}$ são acompanhadas por maiores teores elementais de $\mathrm{Sr}$ e, consequentemente, são menos radiogênicas do que as demais, com exceção da amostra C-337. A amostra CAR-I-51, que possui plagioclásio como mineral constituinte, apresenta o menor índice de alteração química (tabela VI.3) e a maior concentração de Sr da amostras (168 ppm).

\section{VII.2. Sm-Nd em rocha total}

Os valores das razões isotópicas, das idades modelo e $\varepsilon \mathrm{Nd}_{\mathrm{TDM}}$ e recalculados para 590 Ma e 610 Ma são apresentados nas tabelas VII.2 e VII.3.

Os valores de $\varepsilon(0)$ variam entre -12.586 e -11.268 e as idades modelo $\mathrm{T}_{\mathrm{DM}}$ variam de 1.550 a $1.627 \mathrm{Ga}$ (figura VII.2). Valores de $\varepsilon \mathrm{Nd}_{590}$ e $\varepsilon \mathrm{Nd}_{610}$ estão no intervalo -6.251 e 5.472 e -6.045 e -5.275 , respectivamente.

Considerando que idades-modelo de rochas sedimentares representam a mistura de diferentes rochas presentes na área-fonte (McCulloch e Wasseburg, 1978), que o sistema Sm$\mathrm{Nd}$ não sofre alterações significativas durante o metamorfismo, as idades $\mathrm{T}_{\mathrm{DM}}$ obtidas no 
Mesoproterozóico podem refletir a mistura de fontes jovens de idade no Neoproterozóico e de fontes mais antigas que $1,6 \mathrm{Ga}$.

\begin{tabular}{|c|c|c|c|c|c|c|c|}
\hline Amostra & Sm (ppm) & Nd (ppm) & ${ }^{147} \mathrm{Sm} /{ }^{144} \mathrm{Nd}$ & erro $^{1}$ & ${ }^{143} \mathrm{Nd} /{ }^{144} \mathrm{Nd}$ & $\varepsilon_{(0)}$ & $\mathbf{T}_{\mathrm{DM}}(\mathbf{G a})$ \\
\hline C-325c & 7,118 & 37,009 & 0,1163 & 0,0007 & 0,5120 & $-12,301$ & 1,618 \\
\hline C-333 & 4,302 & 21,555 & 0,1207 & 0,0007 & 0,5121 & $-11,409$ & 1,619 \\
\hline C-337 & 3,685 & 18,901 & 0,1179 & 0,0007 & 0,5120 & $-11,822$ & 1,605 \\
\hline$C-340$ & 6,817 & 34,444 & 0,1197 & 0,0007 & 0,5121 & $-11,268$ & 1,590 \\
\hline$C-341$ & 4,037 & 20,367 & 0,1199 & 0,0007 & 0,5120 & $-11,503$ & 1,612 \\
\hline CM-III-25 & 5,981 & 30,314 & 0,1193 & 0,0007 & 0,5120 & $-11,792$ & 1,627 \\
\hline CAR-I-51 & 7,785 & 39,395 & 0,1195 & 0,0007 & 0,5120 & $-11,585$ & 1,613 \\
\hline CAR-IX-129 & 13,418 & 73,351 & 0,1106 & 0,0007 & 0,5120 & $-12,586$ & 1,550 \\
\hline
\end{tabular}

Tabela VII.2: dados isotópicos e elementais do sistema Sm-Nd para as amostras da unidade UBX. Branco analítico para $\mathrm{Sm}=47 \mathrm{pg}$ e para $\mathrm{Nd}=114$; Razão isotópica ${ }^{147} \mathrm{Sm} /{ }^{144} \mathrm{Nd}$ calculada a partir da equação: = $\left[\left(\right.\right.$ Conc Sm/Conc Nd)*0,604491]; Razões isotópicas ${ }^{143} \mathrm{Nd} /{ }^{144} \mathrm{Nd}$ normalizadas para o valor de 0,7219 (DePaolo, 1981); Valor médio para a razão ${ }^{143} \mathrm{Nd} /{ }^{144} \mathrm{Nd}$ do padrão JNdi $=0,512100 \pm 0,000004$; Idade Modelo $\mathrm{T}_{\mathrm{DM}}$ calculada pela equação: $=\left\{\left[\left({ }^{143} \mathrm{Nd} /{ }^{144} \mathrm{Nd}\right)_{\mathrm{am}} / 0,512638\right]-1\right\}^{*} 10^{4}$, onde ${ }^{143} \mathrm{Nd} /{ }^{144} \mathrm{Nd}_{\mathrm{CHUR}}=0,512638$ (Hamilton et al., 1983); $\mathrm{eNd}(0)$ corresponde ao valor atual $(\mathrm{t}=0)$ e é calculado segundo a equação: $=$ $\left.\left\{\left[{ }^{143} \mathrm{Nd} /{ }^{144} \mathrm{Nd}\right)_{\mathrm{am}} / 0,512638\right]-1\right\} * 10^{4}$.

\begin{tabular}{cccc}
\hline Amostra & $\boldsymbol{\varepsilon}_{\text {(TDM) }}$ & $\boldsymbol{\varepsilon}_{(590 \text { Ma) }}$ & $\boldsymbol{\varepsilon}_{\text {(610Ma) }}$ \\
\hline C-325c & 4,294 & $-6,251$ & $-6,045$ \\
C-333 & 4,292 & $-5,687$ & $-5,493$ \\
C-337 & 4,321 & $-5,891$ & $-5,690$ \\
C-340 & 4,355 & $-5,472$ & $-5,275$ \\
C-341 & 4,305 & $-5,720$ & $-5,524$ \\
CM-III-25 & 4,274 & $-5,967$ & $-5,770$ \\
CAR-I-51 & 4,304 & $-5,775$ & $-5,578$ \\
CAR-IX-129 & 4,442 & $-6,108$ & $-5,889$ \\
\hline
\end{tabular}

Tabela VII.3: $\varepsilon \mathrm{Nd}_{\mathrm{TDM}}$ e recalculados para $590 \mathrm{Ma}$ e 610 Ma para as amostras da unidade UBX. 
Valores de $\varepsilon_{\mathrm{Nd}}$ entre -6 e -5 para 590 e 610 Ma confirmam a influência de fontes magmáticas na crosta continental.

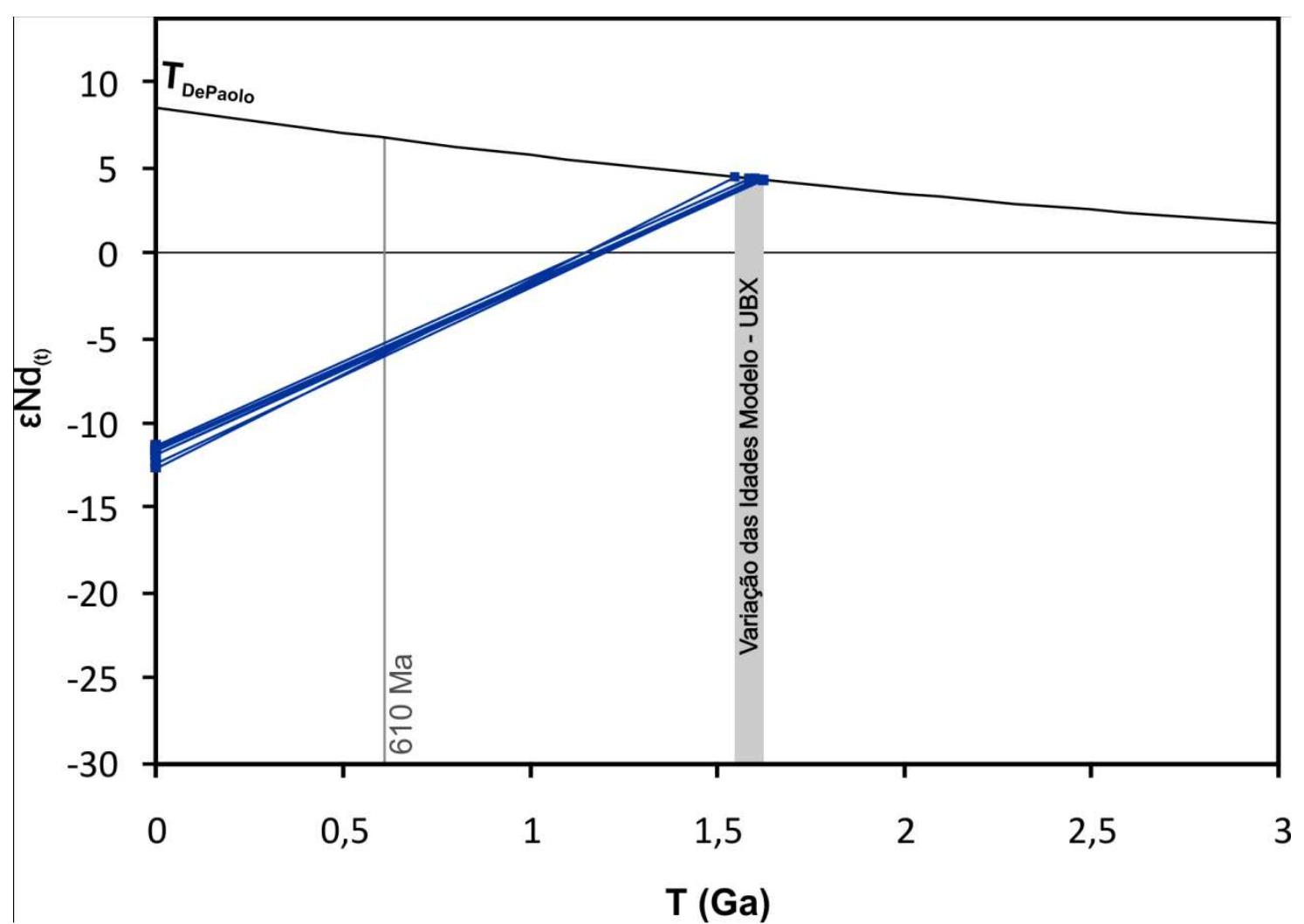

Figura VII.2:gráfico $\mathrm{T}(\mathrm{Ga})$ vs. $\varepsilon \mathrm{Nd}_{(\mathrm{t})}$ para as amostras da unidade UBX. 


\section{Capítulo VIII}

\section{GEOCRONOLOGIA U - PB}

Os cristais de zircão foram separados de maneira aleatória para evitar distorções estatísticas que levassem à supervalorização de uma sub-população sobre outra, considerando o objetivo do trabalho de analisar todo tipo de morfologia de grão possível para a análise mais completa da proveniência do sedimento.

Na amostra C-431 (figura VIII.1), foram realizados 23 pontos de análise em doze (12) cristais de zircão (3 cristais não apresentaram sinal analítico). Quatro grupos foram reconhecidos e analisados, respeitando morfologia e zoneamentos internos observados nas imagens back-scattered (figura VIII.2):

- A: cristais de tamanho entre 250 e $350 \mu \mathrm{m}$, prismáticos, alongados, bipiramidais e angulosos, com pequenos arredondamentos locais nas extremidades e com zoneamento interno de crescimento de origem magmática. A estrutura zonada é de crescimento episódico, indicado pela alternância de zonas de cores claras e escuras. As bordas podem apresentar delgado sobrecrescimento que trunca o zoneamento anterior. Estes cristais foram pouco ou nada retrabalhados por processos sedimentares indicando que foram fornecidos por rochas ígneas no fim da sedimentação da bacia, ou por processos vulcânicos explosivos.

- B: cristais que variam de 80 a $200 \mu \mathrm{m}$, tendendo a equidimensionais, com terminações piramidais preservadas ou não. Zoneamento de crescimento episódico foi observado e varia desde padrões complexos com núcleo arredondado sobrecrescido por três bordas com padrões de zonados distintos que se truncam até grãos com núcleo sem zoneamento aparente e borda com zoneamento bipiramidal. Alguns cristais exibem delgado sobrecrescimento;

- C: cristais de 80 a $120 \mu \mathrm{m}$, em agulhas fragmentadas, mas que ainda preservam terminações bipiramidais subarredondadas a arredondadas. $\mathrm{O}$ zoneamento é homogêneo a concêntrico, sem diferenças entre núcleo e borda, ou com núcleos de 
zoneamento concêntrico e bordas zonadas truncando o anterior. Um cristal de núcleo com textura patchy (Corfu et al., 2003) com duas fases de crescimento de zoneamento diferentes que se truncam também foi observado, além de delgados sobrecrescimentos homogêneos.

- D: cristais fragmentados, com dimensões entre 33 e $95 \mu \mathrm{m}$, exibindo zoneamento interno de crescimento episódico piramidal, ou não zonados. Apresentam bordas intensamente angulosas e com sobrecrescimento delgado.

O sobrecrescimento observado em alguns grãos, independente do grupo a que pertencem, tem dimensões inferiores a $5 \mu \mathrm{m}$.

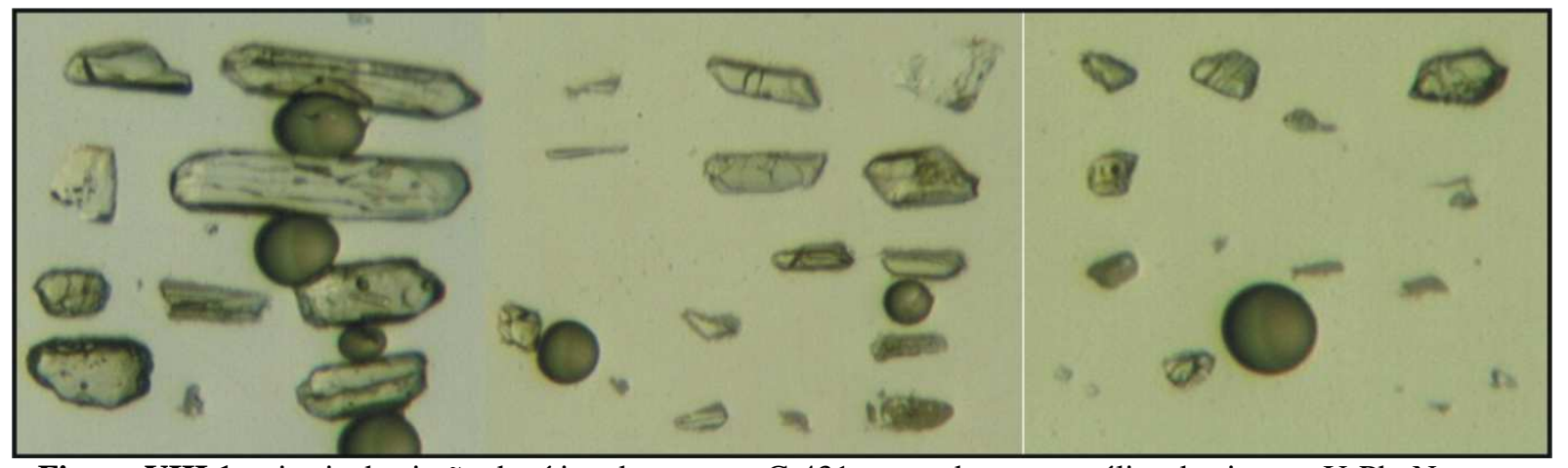

Figura VIII.1: cristais de zircão detrítico da amostra C-431 separados para análise do sistema U-Pb. Notar o faturamento, fragmentação e irregularidades superficiais dos grãos.

As tabelas VIII.1 e VIII.2 e as figuras VIII.3 A, B e C mostram a distribuição das idades da unidade UBX. Dos pontos de análise realizados, 60\% apresentaram valores de concordância acima de $95 \%$ e $26 \%$ valores de concordância abaixo de $90 \%$. A idade $749 \pm 60$ além de ser $30 \%$ discordante, apresentou elevada concentração de $\mathrm{Pb}$ comum e por isso foi desconsiderada. As idades $917 \pm 155$ Ma e $1053 \pm 80$ Ma apresentaram diferenças de até 300 Ma entre as idades ${ }^{207} \mathrm{~Pb} /{ }^{206} \mathrm{~Pb}$ e ${ }^{206} \mathrm{~Pb} /{ }^{238} \mathrm{U}$ com concordância de 65 e $60 \%$, respectivamente, e por isso também foram desconsideradas na interpretação da proveniência, pois forneceram dados inconsistentes. A maioria dos cristais forneceu idades ${ }^{206} \mathrm{~Pb} /{ }^{207} \mathrm{~Pb}$ no Neoproterozóico entre 632 Ma e 691 Ma (concordância entre 96 e 98\%) com classe modal entre 663 Ma e 667 Ma.

Dois cristais do grupo B e 1 do grupo C forneceram idades de 704,2 $\pm 59 \mathrm{Ma}, 764,7 \pm$ 49 Ma e 743,5 \pm 179 Ma. A segunda idade foi obtida em um ponto analítico com $21 \%$ de discordância, feito em um cristal que apresenta fraturas concêntricas que partem do núcleo mais escuro para a borda mais clara. Segundo Corfu et al. (2003) este padrão de fraturamento é característico de cristais metamíticos e possibilitam a percolação de fluidos que ocasionam a 
perda de $\mathrm{Pb}$ do cristal que, por isso, fornece idades irreais. A terceira, além de apresentar discordância de $17 \%$, têm erro associado muito grande fazendo com que a idade varie de 564 Ma a 922 Ma. A primeira, de 704,2 \pm 59 Ma apresenta concordância de $96 \%$ e foi obtida no núcleo de um cristal do grupo $\mathrm{B}$, cristal este com idade ${ }^{206} \mathrm{~Pb} /{ }^{207} \mathrm{~Pb}$ de $592,2 \pm 97 \mathrm{Ma}$, também concordante $(96 \%)$, na borda.

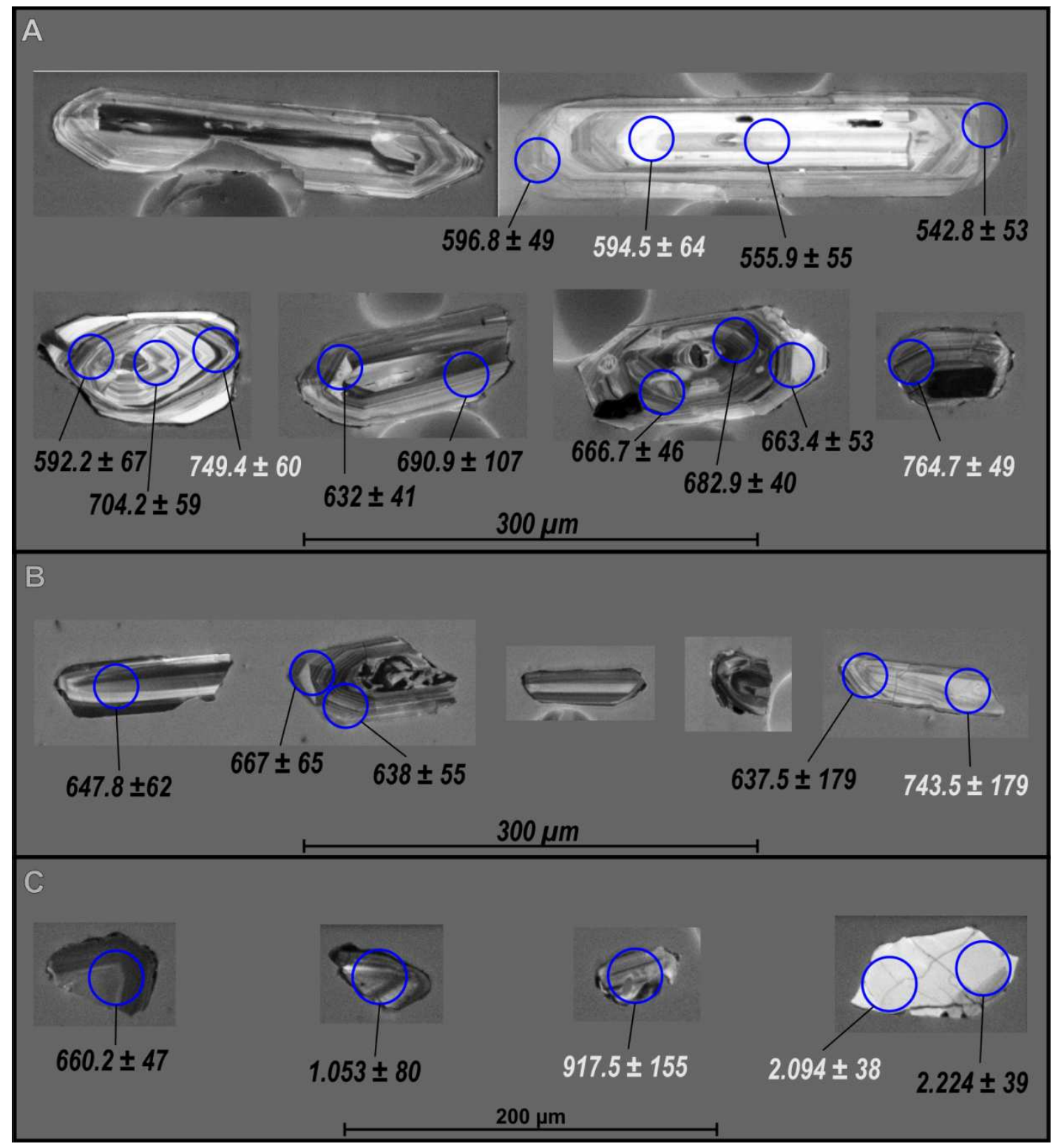

Figura VIII.2: imagens back-scattered dos cristais de zircão detrítico analisados. Os grupos A, B, C e D foram morfologicamente separados segundo sua forma e tipo de zoneamento de crescimento observado. Idades em milhões de anos (Ma); Círculos de cor azul escuro acompanhados por idades de cor preta correspondem às análises com concordância maior que 90\%; Círculos de cor azul escuro acompanhados por idades de cor cinza clara correspondem às idades com valores de concordância menores do que $90 \%$; Cristais sem círculos não apresentaram sinal analítico. 


\begin{tabular}{|c|c|c|c|c|c|c|c|}
\hline Ponto & ${ }^{207} \mathrm{~Pb} /{ }^{235} \mathrm{U}$ & $1 \sigma$ & ${ }^{206} \mathrm{~Pb} /{ }^{238} \mathrm{U}$ & $1 \sigma$ & ${ }^{207} \mathrm{~Pb} /{ }^{206} \mathrm{~Pb}$ & $1 \sigma$ & rho \\
\hline 1.1 & 0,78399 & 0,0112 & 0,08398 & 0,0005 & 0,06423 & 0,0009 & 0,730 \\
\hline 2.1 & 0,97860 & 0,0120 & 0,10994 & 0,0006 & 0,06288 & 0,0008 & 0,739 \\
\hline 3.1 & 0,86095 & 0,0148 & 0,10140 & 0,0006 & 0,05969 & 0,0009 & 0,707 \\
\hline 4.1 & 0,86224 & 0,0102 & 0,09805 & 0,0005 & 0,06470 & 0,0007 & 0,795 \\
\hline 5.1 & 0,77449 & 0,0093 & 0,09316 & 0,0004 & 0,05981 & 0,0006 & 0,797 \\
\hline 6.1 & 0,69533 & 0,0105 & 0,08437 & 0,0005 & 0,05975 & 0,0008 & 0,720 \\
\hline 7.1 & 0,69044 & 0,0084 & 0,08632 & 0,0004 & 0,05835 & 0,0006 & 0,777 \\
\hline 8.1 & 0,70664 & 0,0094 & 0,08706 & 0,0004 & 0,05870 & 0,0007 & 0,763 \\
\hline 9.1 & 0,91771 & 0,0080 & 0,10656 & 0,0004 & 0,06226 & 0,0005 & 0,844 \\
\hline 10,1 & 0,84029 & 0,0122 & 0,09867 & 0,0006 & 0,06169 & 0,0007 & 0,777 \\
\hline 11.1 & 0,89613 & 0,0095 & 0,10667 & 0,0005 & 0,06179 & 0,0006 & 0,812 \\
\hline 12.1 & 0,87957 & 0,0086 & 0,10518 & 0,0006 & 0,06079 & 0,0005 & 0,848 \\
\hline 13.1 & 0,90327 & 0,0240 & 0,10581 & 0,0007 & 0,06249 & 0,0015 & 0,531 \\
\hline 14.1 & 0,87220 & 0,0403 & 0,09916 & 0,0013 & 0,06406 & 0,0027 & 0,413 \\
\hline 15.1 & 0,83115 & 0,0375 & 0,09866 & 0,0011 & 0,06095 & 0,0025 & 0,395 \\
\hline 16.1 & 0,86124 & 0,0161 & 0,10252 & 0,0013 & 0,06124 & 0,0008 & 0,792 \\
\hline 17.1 & 0,82798 & 0,0153 & 0,10078 & 0,0009 & 0,06097 & 0,0007 & 0,796 \\
\hline 18.1 & 0,89550 & 0,0182 & 0,10561 & 0,0009 & 0,06180 & 0,0009 & 0,738 \\
\hline 19.1 & 7,73004 & 0,1817 & 0,40613 & 0,0066 & 0,13978 & 0,0014 & 0,885 \\
\hline 20,1 & 5,09116 & 0,0878 & 0,28670 & 0,0026 & 0,12972 & 0,0012 & 0,840 \\
\hline 21.1 & 0,87860 & 0,0150 & 0,10378 & 0,0009 & 0,06160 & 0,0006 & 0,831 \\
\hline 22.1 & 1,07062 & 0,0330 & 0,10323 & 0,0015 & 0,07445 & 0,0014 & 0,710 \\
\hline 23.1 & 0,94948 & 0,0324 & 0,09691 & 0,0014 & 0,06963 & 0,0026 & 0,473 \\
\hline
\end{tabular}

Tabela VIII.1: razões ${ }^{207} \mathrm{~Pb} /{ }^{235} \mathrm{U},{ }^{206} \mathrm{~Pb} /{ }^{238} \mathrm{U},{ }^{207} \mathrm{~Pb}^{1206} \mathrm{~Pb}$, seus respectivos erros $(1 \sigma)$ e os valores de rho da amostra C-431 da unidade UBX. Os valores em rosa se referem às amostras descartadas. 


\begin{tabular}{|c|c|c|c|c|c|c|c|c|}
\hline & $\begin{array}{c}206 \mathrm{~Pb} / 238 \\
\mathrm{U} \text { Idade } \\
(\mathrm{Ma})\end{array}$ & $\begin{array}{l}\text { erro } \\
\text { (Ma) }\end{array}$ & $\begin{array}{c}{ }^{207} \mathrm{~Pb} / 235 \mathrm{U} \\
\text { Idade } \\
\text { (Ma) }\end{array}$ & $\begin{array}{l}\text { erro } \\
\text { (Ma) }\end{array}$ & $\begin{array}{r}{ }^{207} \mathrm{~Pb} /{ }^{206} \mathrm{~Pb} \\
\text { Idade (Ma) }\end{array}$ & $\begin{array}{l}\text { erro } \\
\text { (Ma) }\end{array}$ & $\begin{array}{c}\text { Conc. } \\
207 / 206\end{array}$ & Obs. \\
\hline 1.1 & 519,8 & 16,0 & 587,8 & 18,4 & 749,4 & 60,3 & 70 & $\begin{array}{l}\text { Alto } \mathrm{Pb} \\
\text { comum }\end{array}$ \\
\hline 2.1 & 672,4 & 20,5 & 692,9 & 20,6 & 704,2 & 59,5 & 96 & \\
\hline 3.1 & 622,6 & 19,1 & 630,6 & 20,2 & 592,2 & 66,7 & 106 & \\
\hline 4.1 & 603,0 & 18,2 & 631,3 & 17,7 & 764,7 & 48,6 & 79 & \\
\hline 5.1 & 574,2 & 17,1 & 582,3 & 16,3 & 596,8 & 48,6 & 97 & \\
\hline 6.1 & 522,1 & 16,0 & 536,0 & 17,4 & 594,5 & 63,6 & 89 & \\
\hline 7.1 & 533,7 & 16,0 & 533,1 & 15,8 & 542,8 & 52,9 & 99 & \\
\hline 8.1 & 538,1 & 16,2 & 542,7 & 16,3 & 555,9 & 55,2 & 98 & \\
\hline 9.1 & 652,7 & 19,2 & 661,1 & 16,8 & 682,9 & 40,0 & 96 & \\
\hline 10,1 & 606,6 & 18,6 & 619,3 & 18,1 & 663,4 & 53,2 & 92 & \\
\hline 11.1 & 653,4 & 19,6 & 649,7 & 17,5 & 666,7 & 46,2 & 99 & \\
\hline 12.1 & 644,7 & 19,5 & 640,7 & 16,8 & 632,0 & 40,9 & 103 & \\
\hline 13.1 & 648,4 & 20,3 & 653,5 & 28,1 & 690,9 & 106,9 & 95 & \\
\hline 14.1 & 609,5 & 23,1 & 636,8 & 43,1 & 743,5 & 179,3 & 83 & \\
\hline 15.1 & 606,6 & 21,5 & 614,2 & 41,0 & 637,5 & 179,5 & 96 & \\
\hline 16.1 & 629,1 & 23,2 & 630,8 & 22,0 & 647,8 & 62,1 & 98 & \\
\hline 17.1 & 619,0 & 20,7 & 612,5 & 19,2 & 638,0 & 55,0 & 98 & \\
\hline 18.1 & 647,2 & 21,4 & 649,3 & 21,5 & 667,0 & 65,4 & 98 & \\
\hline 19.1 & 2197,2 & 81,6 & 2200,1 & 42,8 & 2224,4 & 39,3 & 99 & \\
\hline 20,1 & 1625,0 & 49,9 & 1834,6 & 33,3 & 2094,2 & 38,1 & 78 & \\
\hline 21.1 & 636,5 & 20,8 & 640,2 & 18,6 & 660,2 & 47,4 & 97 & \\
\hline 22.1 & 633,3 & 24,8 & 739,0 & 29,1 & 1053,7 & 79,8 & 60 & $\begin{array}{c}\text { Análise } \\
\text { ruim. }\end{array}$ \\
\hline 23.1 & 596,3 & 23,8 & 677,8 & 41,5 & 917,5 & 155,4 & 65 & $\begin{array}{c}\text { Análise } \\
\text { ruim. }\end{array}$ \\
\hline
\end{tabular}

Tabela VIII.2: idades ${ }^{207} \mathrm{~Pb} /{ }^{235} \mathrm{U},{ }^{206} \mathrm{~Pb} /{ }^{238} \mathrm{U},{ }^{207} \mathrm{~Pb}^{1206} \mathrm{~Pb}$, seus respectivos erros e os valores de concordância da amostra C-431 da unidade UBX. Os valores em rosa se referem às amostras descartadas.

Idades entre 543Ma e 597 Ma foram obtidas no cristal prismático e alongado do grupo A, com nítido arredondamento, por abrasão na deposição, das terminações piramidais, apresentam concordância acima de 95\% (com uma exceção de $89 \%$ de concordância, tabela VIII.2). No entanto esses valores encontram-se, na margem de erro, na idade do 
metamorfismo para o Grupo Carrancas, obtidos pelo método U-Pb ID-TIMS em monazita

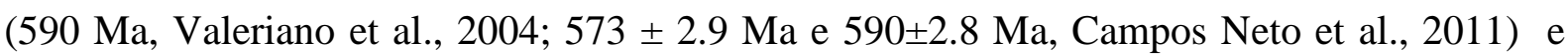
para a Nappe Andrelândia (Campos Neto et al., 2007). Essas idades aumentam progressivamente da borda direita para a borda esquerda do cristal (tomar figura VIII.2 como referência), e o mesmo encontra-se fraturado (figura VIII.1) sugerindo abertura do sistema U-Pb por percolação de fluidos (Corfu et al., 2003). A ausência de sinal analítico no outro cristal alongado e bipiramidal com fraturas semelhantes reforçam a hipótese de que houve abertura do sistema isotópico.

A

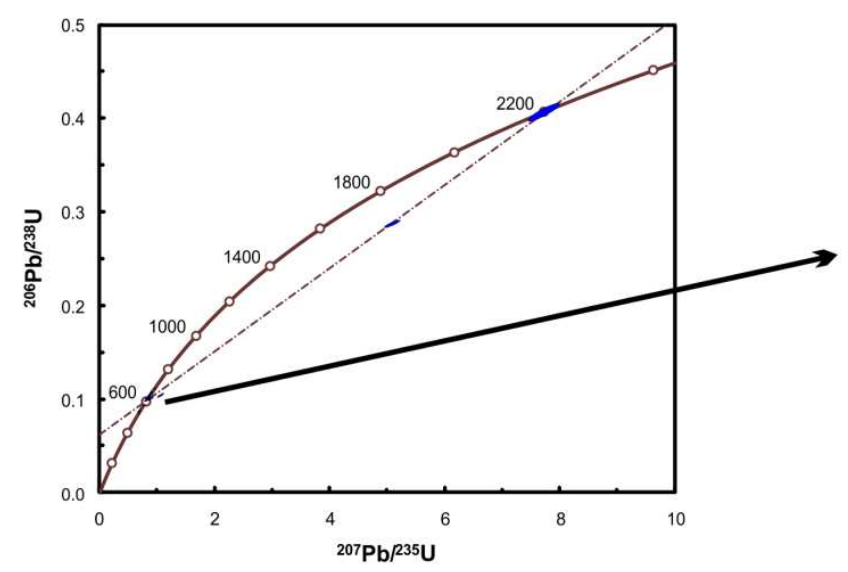

B

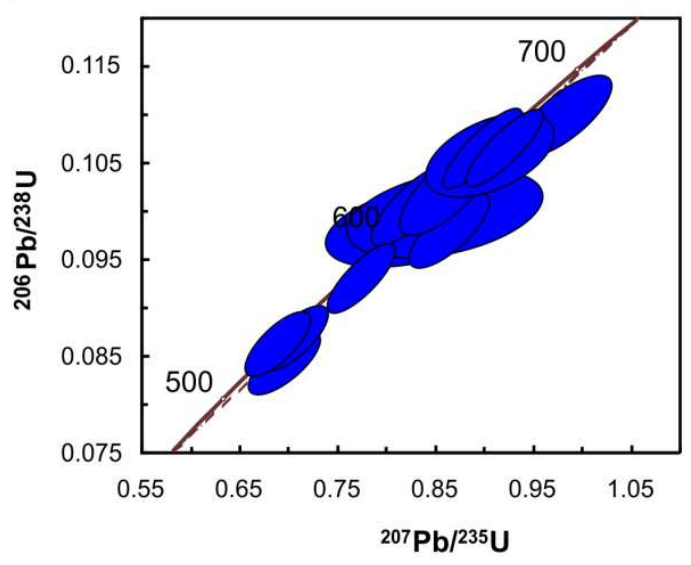

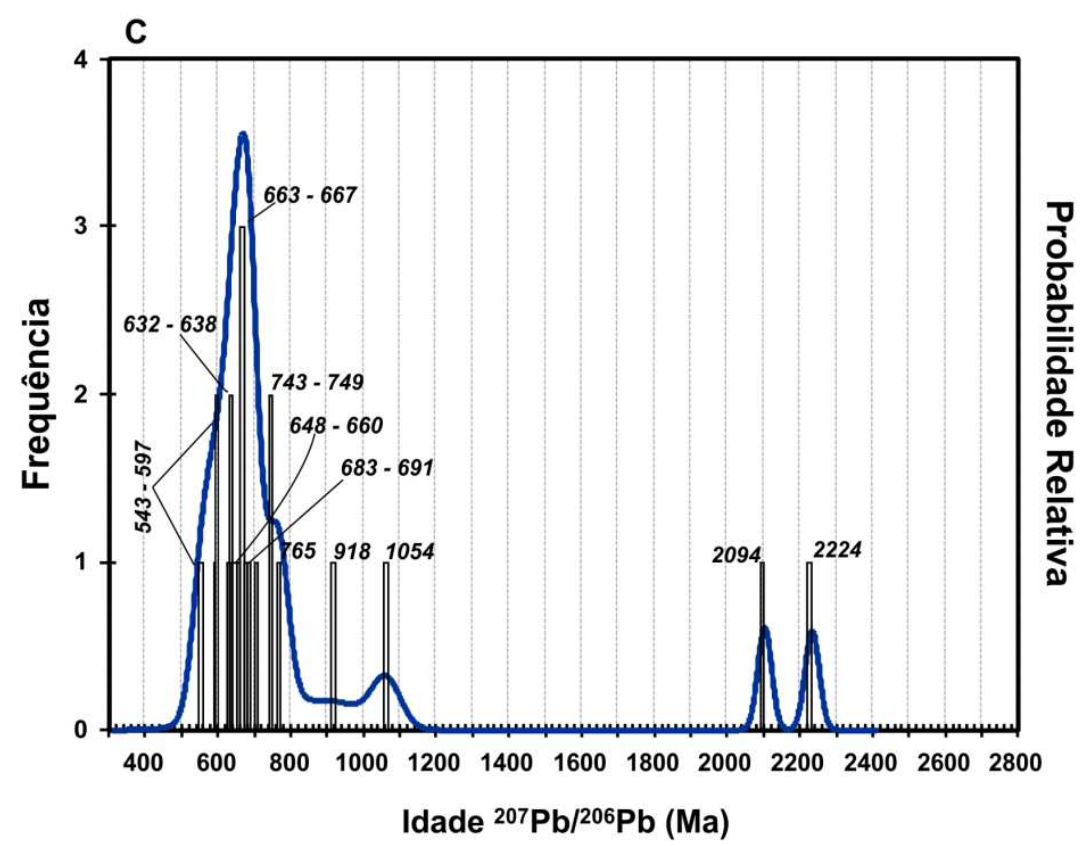

Figura VIII.16: diagramas concórdia ${ }^{207} \mathrm{~Pb} /{ }^{238} \mathrm{U} v$ s. ${ }^{206} \mathrm{~Pb} /{ }^{238} \mathrm{U}\left(\mathbf{A}\right.$ e B) e idades ${ }^{207} \mathrm{~Pb} /{ }^{206} \mathrm{~Pb}$ obtidas em cristais de zircão detrítico da amostra C-431. 
Um cristal do grupo B, de idade 592,2 $\pm 67 \mathrm{Ma}$, apresenta alto erro associado e baixa discordância de 6\%. Se esse valor também se encontra na margem de erro das idades metamórficas, o cristal também exibe arredondamento por abrasão. Assim, esse valor pode representar mistura de idades, com o spot do laser atingindo tanto o cristal com zoneamento ígneo quanto a borda de sobrecrescimento mais claro sem zoneamento.

Um cristal do grupo C sem zoneamento forneceu duas idades no Paleoproterozóico: borda de $2094 \pm 38$ Ma (78\% de concordância) e núcleo de $2224 \pm 39$ Ma $(99 \%$ de concordância).

Portanto, considerou-se que a deposição dos sedimentos se deu entre $630 \mathrm{Ma}$ (idade mais jovem obtida foi de $632 \mathrm{Ma}$ ) e $590 \mathrm{Ma}$, ou 611 Ma (idades mínimas para o metamorfismo nas nappes Carrancas e Andrelândia, respectivamente).

Descartadas as idades com concordância abaixo de 95\%, os cristais detríticos de zircão mostram uma distribuição essencialmente unimodal, no Neoproterozóico, fim-Criogeniano, com classe modal de 665 Ma. É um valor comparável com a idade U-Pb TIMS de cristais de zircão do Xisto Santo Antônio, Nappe Andrelândia (Campos Neto et al., 2004) e com a idade $\mathrm{U}-\mathrm{Pb} \mathrm{SHRIMP}$ do magmatismo básico toleítico precursor das rochas retroeclogíticas da Nappe Liberdade (Campos Neto et al., 2011). Deve representar a época de maior atividade ígnea félsica na área-fonte. 


\section{CAPÍTULO IX}

\section{Ambiente Deposicional e}

\section{ÁREA-FONTE PRINCIPAL}

\section{IX.1. Ambiente de deposição}

A figura IX.1 mostra gráficos elaborados, segundo diversos autores, para a classificação quanto ao ambiente tectônico de deposição de rochas sedimentares.

Segundo estes gráficos as amostras da unidade UBX são compatíveis quimicamente com sedimentos depositados em ambientes de colisão continental (figura IX.1 A) e que tiveram como área-fonte arco magmático continental e rochas de composição semelhante à da crosta continental superior (figuras IX.C, D, E e F). Razões $\quad \mathrm{Th} / \mathrm{Sc}$ abaixo mas próximas de 1,0 (figuras IX.1 B e C) e baixas razões La/Th (figura IX.1 F) indicam forte contribuição de rochas félsicas e a figura IX.B mostra que a área-fonte esteve submetida a um intemperismo químico moderado ou que os sedimentos precursores sofreram intemperismo químico de intensidade e período de tempo moderados; ambos sugerem ambientes orogênicos com exposição da área-fonte penecontemporânea à sedimentação.

Razões ${ }^{87} \mathrm{Sr} /{ }^{86} \mathrm{Sr}$ relativamente baixas, $\varepsilon N d$ pouco negativo (figuras C, D e F) sugerem assinatura isotópica distinta daquelas consideradas para ambientes tectônicos de margem passiva e para crosta continental antiga. 


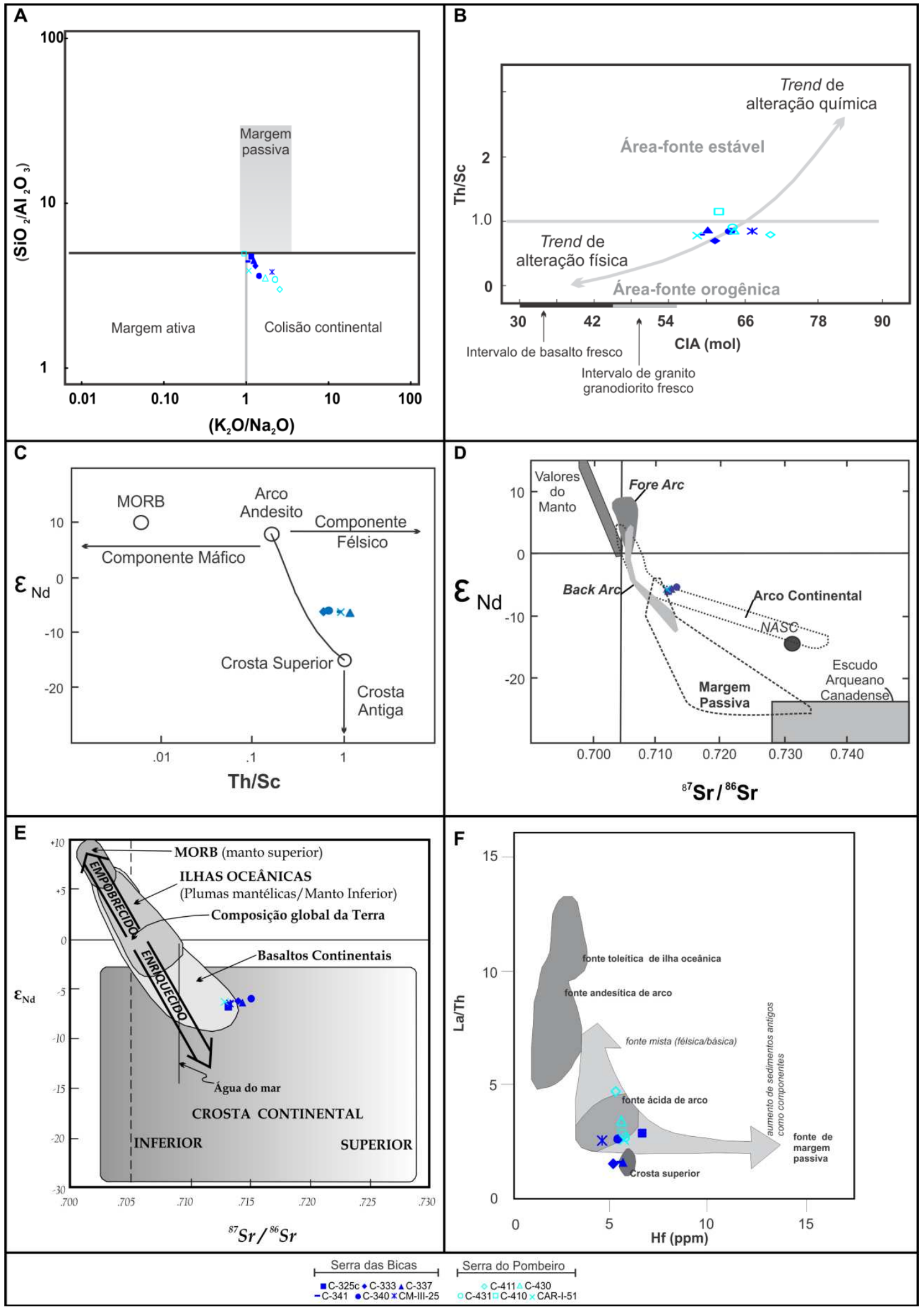

Figura IX.1: diagramas de classificação química segundo o ambiente tectônico de deposição. $\varepsilon N d$ e razões ${ }^{87} \mathrm{Sr} /{ }^{86} \mathrm{Sr}$ foram recalculados para $630 \mathrm{Ma}$ (pico de idade dos cristais de zircão detrítico da amostra C-431). A e

B: extraídos de Campos Neto et al. (2011) formulados com base nos dados de McLennan et al. (1990); C: McLennan et al. (1993); D: McLennan et al. (1990); E: White (2009); F: Floyd e Leveridge (1987). 


\section{IX.2. Área-Fonte principal}

A assinatura geoquímica, isotópica e as idades ${ }^{207} \mathrm{~Pb} /{ }^{206} \mathrm{~Pb}$ no Neoproterozóico de cristais de zircão detrítico obtidas para a amostra C-431 foram comparadas com as idades de rochas meta-ígneas da Nappe Socorro-Guaxupé, obtidas por Basei et al. (1995), Ebert et al. (1996), Topfner (1996) e Janasi (1999). Rochas de idade paleoproterozóica são encontradas no substrato do Sistema de Nappes Andrelândia (Campos Neto et al., 2011) e na Faixa Apiaí (Kaufuss, 2001; Prazeres Filho, 2005; Ribeiro, 2006; Siga Jr et al., 2011). Busca-se verificar se essas rochas poderiam ser as fontes mais prováveis para o sedimento. Idades U-Pb TIMS e SHRIMP em cristais de monazita e de zircão, e dados isotópicos ${ }^{87} \mathrm{Sr}^{8}{ }^{86} \mathrm{Sr}_{625 \mathrm{Ma}}$, valores de $\varepsilon \mathrm{Nd}_{625 \mathrm{Ma}}$ e de elementos traço foram utilizados e estão representados na tabelas IX.1 e figuras IX.2 e IX.3.

A Nappe Socorro Guaxupé é interpretada como um domínio de arco magmático desenvolvido na margem continental ativa da Placa Paranapanema (Campos Neto, 2000) apresenta-se como uma espessa lasca de aproximadamente $15 \mathrm{~km}$ de espessura de crosta continental profunda. É segmentada em dois lobos separados por rampas laterais de alto ângulo: Guaxupé a norte e Socorro a sul e dividida em três Unidades principais (Campos Neto \& Caby, 2000): Unidade Granulítica Basal (formada por granulitos enderbíticos associados a leucossomas e veios de charnokitos, além de intercalações de gnaisse gabro-norítico, considerados como intrusões sin-metamórficas); Unidade Diatexítica Intermediária (corresponde a biotita-hornblenda diatexitos estromáticos, envoltos por biotita-hornblenda granitos e por granitos porfiríticos deformados. No topo da unidade predominam tonalitos e gnaisses granodioríticos com lentes metabásicas e bandas estromáticas leucotonalíticas a trondhjemíticas); Unidade Migmatito Superior (migmatitos pelíticos a semi-pelíticos e lentes subordinadas de quartzito, gnaisse cálciossilicático, raros mármores e metamáficas intrusivas). Toda a nappe possui um comportamento geral sub-horizontal e, sua terminação meridional é truncada por um cinturão de cisalhamento de direção ENE. Granitos sin- e tardiorogênicos são abundantes (Supersuite mangerítico-granítica São José do Rio Pardo, granitos tipo Pinhal e Nazaré Paulista; maciço Serra do Lopo e suite Bragança Paulista) e as estruturas sin-metamórficas são cortadas por plútons dioríticos e sieníticos circulares, ricos em potássio, como as suítes Pedra Branca e Capituva (Campos Neto et al., 1988; Janasi et al., 1993). Ebert et al. (1996) consideram que a deformação da área ocorreu entre 655 Ma e 595 Ma, intervalo obtido com datações de um granitóide migmatítico e de granito tardi-orogênico, 
respectivamente. A partir de datações pelo sistema U-Pb em zircão de granitos sinorogênicos, Janasi (1999) sugere que o metamorfismo regional afetou a área há $625 \pm 5$ Ma.

\begin{tabular}{|c|c|c|}
\hline & $\begin{array}{c}{ }^{207} \mathrm{~Pb} /{ }^{206} \mathrm{~Pb} \text { em zircão } \\
\text { (zir) e U-Th-Pb em } \\
\text { monazita (mnz) - idades } \\
\text { em Ma }\end{array}$ & OBSERVAÇÕES \\
\hline MONZOGRANITO SUITE SERRA DO LOPO & (zir) $595 \pm 12^{\mathrm{B}}$ & cristalização magmática \\
\hline SIENITO PEDRA BRANCA & (zir) $612 \pm 3^{C}$ & cristalização magmática \\
\hline GRANITO TIPO PINHAL & (zir) $624,6 \pm 3.0^{\mathrm{D}}$ & \\
\hline \multirow{2}{*}{ SUPERSUITE SÃO JOSÉ DO RIO PARDO } & (zir) $623 \pm 3.0^{\mathrm{D}}$ & $\begin{array}{l}\text { mangerito maciço São } \\
\text { Pedro de Caldas }\end{array}$ \\
\hline & (zir) $625 \pm 7^{\mathrm{A}}$ & $\begin{array}{l}\text { mangerito maciço } \\
\text { Divinolândia }\end{array}$ \\
\hline BATÓLITO SOCORRO & (zir) $629 \pm 3^{c}$ & \\
\hline \multirow{2}{*}{ MIGMATITO NAZARÉ PAULISTA } & $(\mathrm{mnz}) 625 \pm 8^{\mathrm{F}}$ & leucossoma granítico \\
\hline & $(\mathrm{mnz}) 624 \pm 4 \mathrm{~F}$ & leucossoma trondhjemitico \\
\hline \multirow{2}{*}{ GRANITO NAZARÉ PAULISTA } & (zir) $631.5 \pm 4.8^{\mathrm{D}}$ & \\
\hline & $(\mathrm{mnz}) 623,6 \pm 1,9^{\mathrm{D}}$ & \\
\hline GRANULITO DO COMPLEXO PARAISÓPOLIS & (zir) $646 \pm 7^{E}$ & \\
\hline $\begin{array}{l}\text { CHARNOKITO GNÁISSICO DO COMPLEXO } \\
\text { METAMÓRFICO PIRACAIA }\end{array}$ & (zir) $653 \pm 13^{\mathrm{E}}$ & idade do protólito ígneo \\
\hline $\begin{array}{c}\text { CHARNOKITO GNÁISSICO CÁLCIO- } \\
\text { ALCALINO }\end{array}$ & (zir) $643 \pm 12^{\mathrm{A}}$ & \\
\hline \multirow{2}{*}{$\begin{array}{l}\text { GNAISSE GRANÍTICO MILONÍTICO } \\
\text { DOMÍNIO SOCORRO }\end{array}$} & (zir) $642 \pm 1^{\mathrm{E}}$ & cistalização magmática \\
\hline & (zir) $650 \pm 2^{E}$ & herança \\
\hline $\begin{array}{l}\text { MIGMATITO ESTROMÁTICO COM } \\
\text { NEOSSOMA DO GRANITO SOCORRO I }\end{array}$ & $\begin{array}{l}\text { (zir) } 655 \pm 2^{\text {B }} \\
645 \pm 12^{\text {B }}\end{array}$ & \\
\hline
\end{tabular}

Tabela IX.1: idades ${ }^{207} \mathrm{~Pb} /{ }^{206} \mathrm{~Pb}$ em monazita e zircão para granulitos, charnokitos e granitos da Nappe SocorroGuaxupé. ${ }^{\text {A }}$ : Basei et al. (1995); ${ }^{\mathrm{B}}$ : Ebert et al. (1996); ${ }^{\mathrm{C}}$ : Topfner (1996); ${ }^{\mathrm{D}}$ : Janasi (1999);

${ }^{\mathrm{E}}$ : Hackspacher et al. (2003); ${ }^{\text {F }}$ : Martins et al. (2009). 
Os granitos tipo Nazaré Paulista dificilmente seriam área-fonte dos sedimentos, pois ocorrem como corpos pequenos associados às rochas metassedimentares (Janasi, 1999). São granitos anatéticos no Complexo Metamórfico Piracaia (Campos Neto et al., 1983; Janasi et al., 2005), Unidade Migmatítica Superior da Nappe Socorro-Guaxupé, que possuem cerca de $630 \mathrm{Ma}$ (U-Pb TIMS em zircão) e cerca de $625 \mathrm{Ma}$ (U-Pb TIMS em monazita).

O soerguimento e exumação da crosta média-superior da Nappe Socorro-Guaxupé, lobo Guaxupé, foi cinematicamente ativo até as intrusões rasas de rochas sieníticas isotrópicas há 612 Ma (Janasi, 1999). A partir de 590 Ma o lobo meridional desta nappe, Socorro, registrou, no magmatismo da Província Granítica Itú (Janasi et al., 2009) o intenso adelgaçamento litosférico e colapso do domínio orogênico interno.

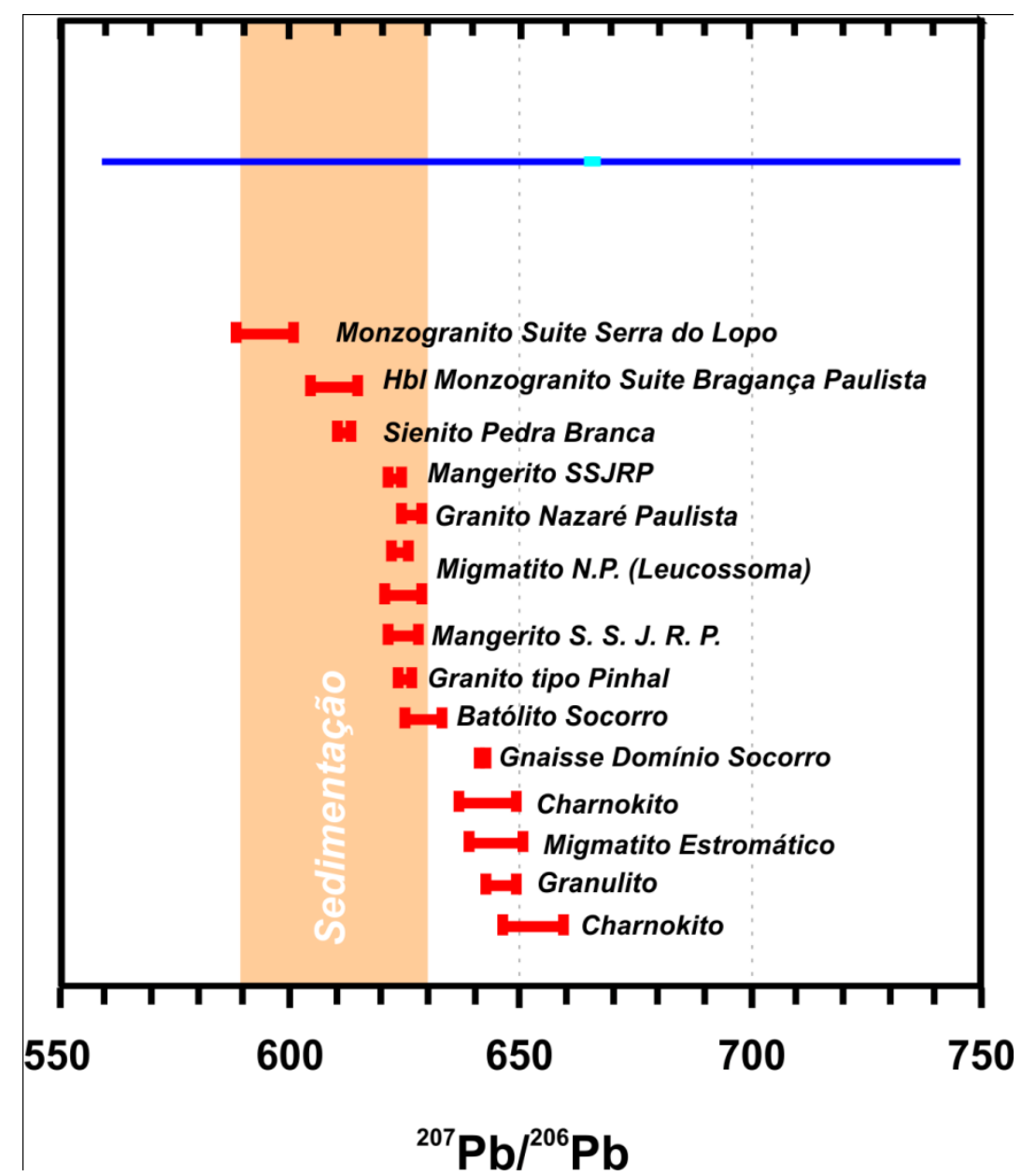

Figura IX.2: ilustração comparativa dos intervalos de idades com concordância acima de $90 \%$ (em Ma) obtidas em zircões detríticos da amostra C-431 (em azul; azul claro: classe modal) com os intervalos de idade de granulitos, charnokitos, migmatitos, gnaisses, granitos, mangeritos, monzogranitos e sienitos da Nappe SocorroGuaxupé descritos na tabela IX.1. Intervalo laranja (630 - $590 \mathrm{Ma})$ refere-se ao período máximo possível para a sedimentação definido pela idade do cristal de zircão detrítico mais jovem e pela idade do metamorfismo no sistema de nappes Carrancas. 
Charnokitos e migmatitos de idade entre 655 Ma e 642 Ma pertencentes a Nappe Socorro-Guaxupé podem ter sido, em parte, a fonte de cristais detríticos de zircão, considerando os erros associados. Os cristais detríticos ao redor de $635 \mathrm{Ma}$ (com seus erros associados) podem ter sido fornecidos pelas rochas ígneas sin-colisionais (granito tipo Pinhal, mangeritos da Supersuite São José do Rio Pardo e batólito Socorro-Ipuiuna).

A classe modal de idades de zircão detrítico (663-667 Ma, figura VI.3) não está representada nas idades deste magmatismo plutônico cálcio-alcalino potássico e mangerítico da Nappe Socorro-Guaxupé. O substrato deste magmatismo são rochas plutônicas de arco: metatonalitos que ocorrem como paleossoma em migmatitos, granada enderbito gnaisses e granada granulitos básicos (Campos Neto e Caby, 2000). Destas, os granulitos máficos, intermediários e ácidos configuram uma suíte cálcio-alcalina, cujos dados isotópicos registram $\mathrm{Nd}$ TDM entre 2,29 Ga e 1,17 Ga e $\varepsilon \mathrm{Nd}_{625 \mathrm{Ma}}$ entre -18,7 e 0,0 com predominância dos valores fracamente negativos, além de baixas razões iniciais de $\operatorname{Sr}_{625}$ (Janasi, 1999). Essas rochas, se de idades ainda desconhecidas, representam o registro neoproterozóico mais primitivo do arco magmático.

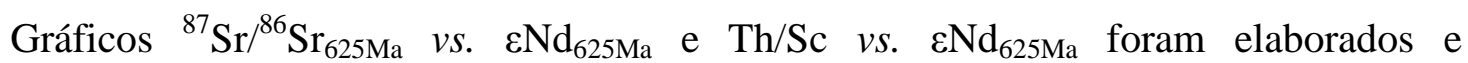
apresentados na figura IX.3 para comparações, pois elementos traço como Th e Sc são transferidos quantitativamente para os sedimentos (McLennan et al., 1990) e o sistema Sm-Nd tende a permanecer fechado em condições até metamórficas (White, 2009). Os gráficos mostram que as amostras da unidade UBX plotam no campo dos granulitos cálcio-alcalinos da Nappe Socorro-Guaxupé. Corrobora assim a hipótese de que estas rochas, ou rochas vulcânicas co-genéticas, possam ter sido a fonte para os sedimentos da bacia.
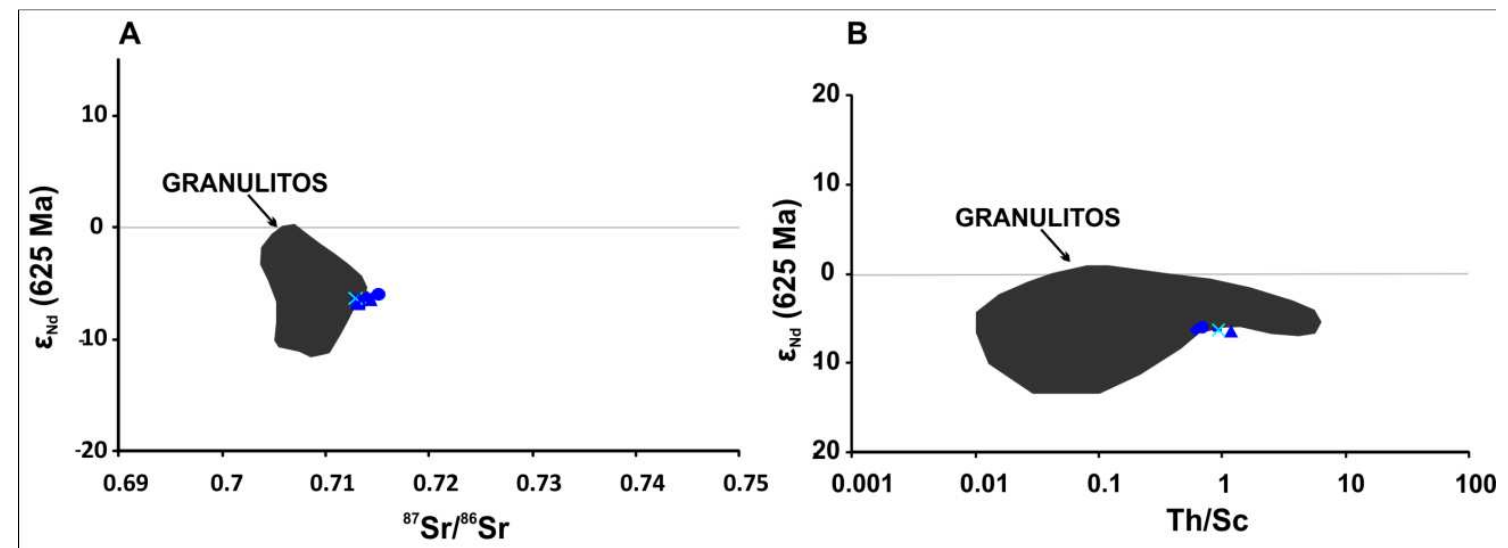

Figura IX.2: diagramas. ${ }^{87} \mathrm{Sr} /{ }^{86} \mathrm{Sr} v s$. $\varepsilon \mathrm{Nd}$ e Th/Sc $v$ s. $\varepsilon \mathrm{Nd}$ para as amostras da unidade UBX, com os campos dos granulitos da Nappe Socorro-Guaxupé (Janasi, 1999). 
A idade de 2224 Ma obtidas em um cristal de zircão detrítico sugere contribuição secundária de fonte mais antiga (Paleoproterozóico) para os sedimentos. As idades modelo$\mathrm{Nd}$ no (entre 1,5 e 1,6 Ga podem representar uma mistura de fontes de idades diferentes, entre o Neoproterozóico e o Paleoproterozóico. Séries ortognáissicas paleoproterozóicas (Riaciano) e arqueanas (Neoarqueano) ocorrem no substrato do Sistema de Nappes Andrelândia (Campos Neto et al., 2011). Idades no Riaciano também foram obtidas em ortognaisses no interior de núcleos antiformais na Faixa Apiaí (Kaufuss, 2001; Ribeiro, 2006; Siga Jr et al., 2011) e está registrada em zircões herdados de granitóides neoproterozóicos desta mesma faixa orogênica (Prazeres Filho, 2005).

A distribuição unimodal de idades fim-Criogeniano dos cristais detríticos de zircão, a pouca representatividade de idades no Paleoproterozóico e a ausência de assinaturas químicas de margem passiva, inviabilizam o domínio cratônico (Cráton do São Francisco) como uma das áreas-fonte possíveis para as rochas da Unidade Biotita Xisto. 


\section{CAPÍtUlo X}

\section{COMPARAÇõES ENTRE A UNIDADE BIOTITA XISTO E A FORMAÇÃo CAMPESTRE}

Para a análise de proveniência da Formação Campestre (FC) do Grupo Carrancas e sua comparação com a unidade UBX, foram realizadas análises químicas de elementos maiores (tabela X.1), menores e traços, análises isotópicas $\mathrm{Sm}, \mathrm{Nd}$ e $\mathrm{Sr}$ do grafita-muscovita xisto e a determinação de idades absolutas em zircões detríticos de uma amostra de muscovita quartzito (CAR-II-179).

\section{X.1. Geoquímica de elementos maiores e menores}

As diferenças geoquímicas entre as amostras das unidades analisadas são marcantes no que se refere aos elementos maiores, principalmente nas concentrações dos óxidos de $\mathrm{Fe}^{3+}$, $\mathrm{Al}^{3+}, \mathrm{Si}^{4+}, \mathrm{Mg}^{2+}, \mathrm{Ca}^{2+}$ e $\mathrm{Na}^{+}$(tabela X.1).

\begin{tabular}{|c|c|c|c|c|c|c|c|c|c|c|}
\hline & $\mathrm{SiO}_{2}$ & $\mathrm{TiO}_{2}$ & $\mathbf{A l}_{2} \mathbf{O}_{3}$ & $\mathrm{Fe}_{2} \mathbf{O}_{3}$ & MnO & MgO & $\mathrm{CaO}$ & $\mathrm{Na}_{2} \mathrm{O}$ & $\mathbf{K}_{2} \mathbf{O}$ & $\mathbf{P}_{2} \mathbf{O}_{5}$ \\
\hline UBX & $\begin{array}{c}58,25 \\
a \\
68,09\end{array}$ & $\begin{array}{c}0,80 \mathrm{a} \\
1,03\end{array}$ & $\begin{array}{c}14,14 \\
a \\
19,69\end{array}$ & $\begin{array}{c}5,65 \mathrm{a} \\
7,92\end{array}$ & $\begin{array}{c}0,09 \mathrm{a} \\
0,17\end{array}$ & $\begin{array}{c}2,32 \mathrm{a} \\
3,48\end{array}$ & $\begin{array}{c}0,80 \mathrm{a} \\
1,90\end{array}$ & $\begin{array}{c}1,79 a \\
2,81\end{array}$ & $\begin{array}{c}2,69 a \\
4,69\end{array}$ & $\begin{array}{c}0,14 \mathrm{a} \\
0,22\end{array}$ \\
\hline CAR-I-32 & $\begin{array}{c}50,8 \\
5\end{array}$ & 1,02 & 26,99 & 12,46 & 0,16 & 1,84 & 0,36 & 0,36 & 2,02 & 0,33 \\
\hline CAR-II-76 & 55,14 & 0,92 & 25,35 & 8,73 & 0,17 & 1,54 & 0,21 & 1,04 & 2,95 & 0,17 \\
\hline SC-07 & 58,17 & 1,00 & 22,77 & 6,86 & 0,11 & 1,37 & 0,04 & 0,99 & 4,07 & 0,09 \\
\hline SC-08 & 54,65 & 1,06 & 27,71 & 6,11 & 0,07 & 0,84 & 0,14 & 1,63 & 3,31 & 0,09 \\
\hline SC-30B & 42,93 & 1,23 & 33,75 & 6,19 & 0,04 & 0,88 & 0,14 & 0,91 & 8,15 & 0,15 \\
\hline SC-30C & 43,79 & 1,14 & 33,97 & 4,89 & 0,05 & 0,97 & 0,08 & 1,03 & 8,21 & 0,15 \\
\hline
\end{tabular}

Tabela X.1: resultados obtidos para elementos maiores e menores por análises de FRX para amostras da Formação Campestre (em laranja). As amostras com sigla SC foram compiladas de Silva (2010). Os intervalos obtidos para as amostras da unidade UBX foram colocados para comparação (em azul). Valores em \% peso de óxido. 
Nos diagramas Harker ilustrados na figura X.1 observa-se, para as amostras FC, correlações negativas entre $\mathrm{SiO}_{2}$ e $\mathrm{TiO}_{2}, \mathrm{Al}_{2} \mathrm{O}_{3}$ e $\mathrm{MgO}$ e $\mathrm{CaO}$ e positiva entre $\mathrm{SiO}_{2}$ e $\mathrm{Na}_{2} \mathrm{O}$ e $\mathrm{K}_{2} \mathrm{O}$. Destaca-se que as amostras UBX exibem, para o $\mathrm{K}_{2} \mathrm{O}$, uma correlação negativa e apresentam maiores concentrações de $\mathrm{SiO}_{2}, \mathrm{MgO}, \mathrm{CaO}, \mathrm{Na}_{2} \mathrm{O}$ e $\mathrm{P}_{2} \mathrm{O}_{5}$ e menores de $\mathrm{TiO}_{2}$, $\mathrm{Fe}_{2} \mathrm{O}_{3}$ e $\mathrm{Al}_{2} \mathrm{O}_{3}$. Estas características provavelmente se devem ao fato de que as amostras do grafita-muscovita xisto da FC possuem maior concentração de minerais aluminosos e ricos em Fe, como cloritóide, estaurolita e granada. Por outro lado, as amostras da unidade UBX apresentam maiores proporções de quartzo, biotita e clorita, com a presença local de plagioclásio e apatita como mineral acessório principal.

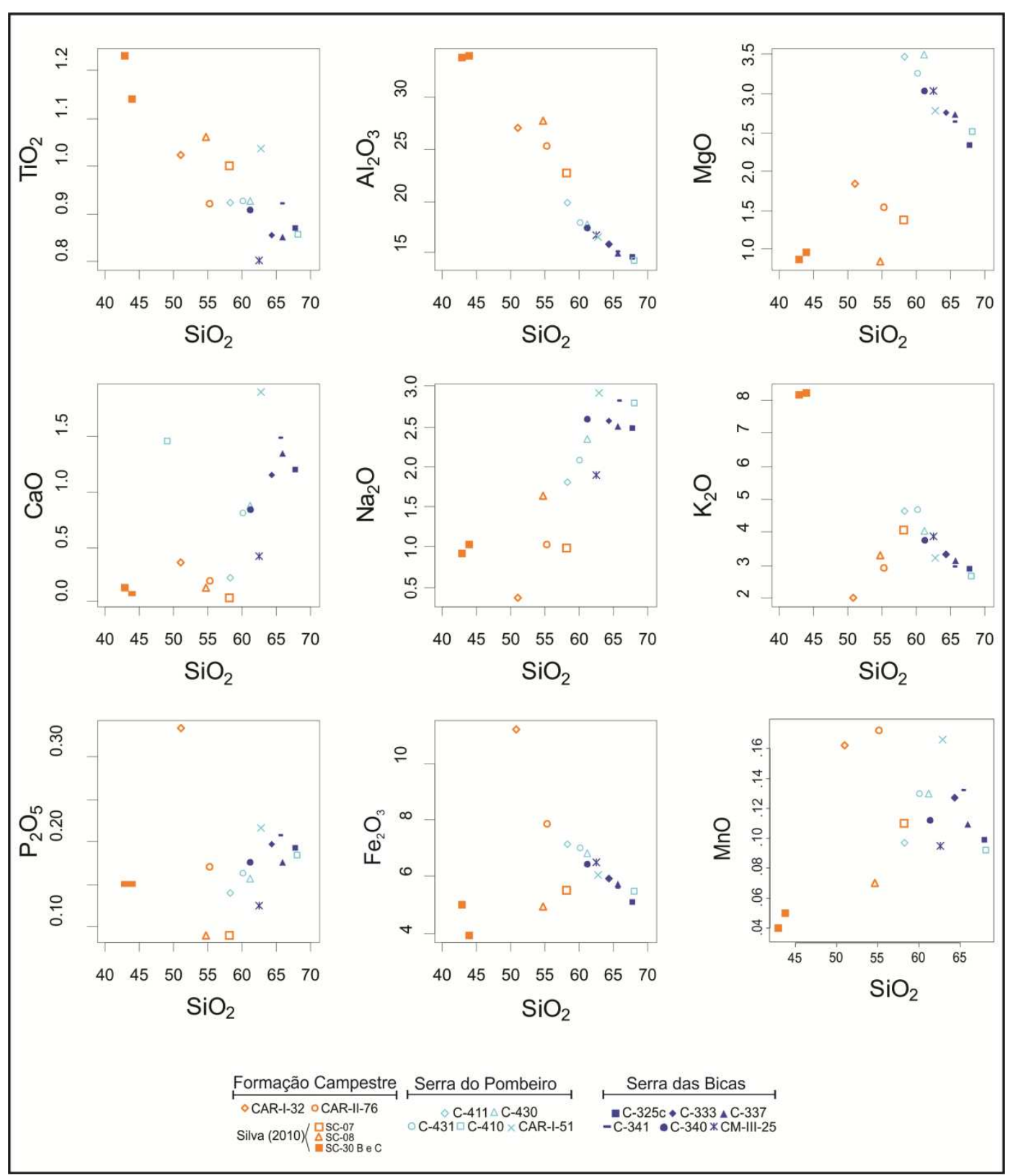


Figura X.1: diagramas Harker para as amostras do do grafita-muscovita xisto da FC. Amostras da unidade UBX foram plotadas para comparação.

As amostras CAR-I-32, CAR-II-76, SC-07, SC-08 localizam-se na região da Serra do Pombeiro, e encontram-se sob condições metamórficas de fácies xisto-verde em presença de cloritóide. Estas são enriquecidas em $\mathrm{SiO}_{2}, \mathrm{MgO}, \mathrm{CaO}, \mathrm{Fe}_{2} \mathrm{O}_{3}, \mathrm{MnO}$ e empobrecidas em $\mathrm{TiO}_{2}, \mathrm{Al}_{2} \mathrm{O}_{3}$ e $\mathrm{K}_{2} \mathrm{O}$ quando comparadas com as amostras SC-30B e SC-30C localizadas na região da Serra das Bicas e sob condições de fácies anfibolito inferior em presença de estaurolita e granada, com cianita eventual. As concentrações de $\mathrm{Na}_{2} \mathrm{O}$ e $\mathrm{P}_{2} \mathrm{O}_{5}$ são muito semelhantes e não apresentam diferenças quanto à região que em que as amostras foram coletadas.

As maiores concentrações de óxidos de alumínio e potássio e menores de $\mathrm{SiO}_{2}$ nas amostras SC-30B e SC-30B respondem por maiores teores modais de muscovita, granada e estaurolita em relação ao quartzo, indicando sedimento predominantemente pelítico. Maior teor de cloritóide na amostra CAR-I-32 deve-se ao enriquecimento em ferro no pelito aluminoso original.

\section{X.1.1. Classificação Química}

Como os pelitos não são considerados na classificação de Pettijohn (1972), apenas o diagrama de Herron (1988) foi utilizado para a classificação dos xistos grafitosos (figura X.2).

Observa-se que as amostras do grafita-muscovita xisto da FC distanciam-se, no campo dos pelitos, das amostras UBX e destaca o caráter rico em ferro do metapelito CAR-I-32.

\section{X.1.2. Chemical Index of Alteration (CIA)}

Contrariamente às amostras da unidade UBX, valores intermediários a altos de CIA foram obtidos para as amostras do grafita-muscovita xisto da FC (tabela X.2), entre 76 e 88,72. Essas relações favorecem uma intensa reciclagem e alteração do sedimento original, compatíveis com ciclos longos e/ou repetitivos de intemperismo químico, ou períodos de extremas condições de clima quente e úmido.

No gráfico ternário $\mathrm{A}\left(\mathrm{Al}_{2} \mathrm{O}_{3}\right)-\mathrm{CN}\left(\mathrm{CaO}+\mathrm{Na}_{2} \mathrm{O}\right)-\mathrm{K}\left(\mathrm{K}_{2} \mathrm{O}\right)$ de avaliação de intensidade de intemperismo (figura X.3) as amostras do grafita-muscovita xisto da FC da Serra do Pombeiro plotam no estágio final do trend de alteração de rochas com composição 
inicial semelhante a da crosta continental superior, mais rica em feldspato potássico do que plagioclásio, diferenciando-as das amostras da unidade UBX.

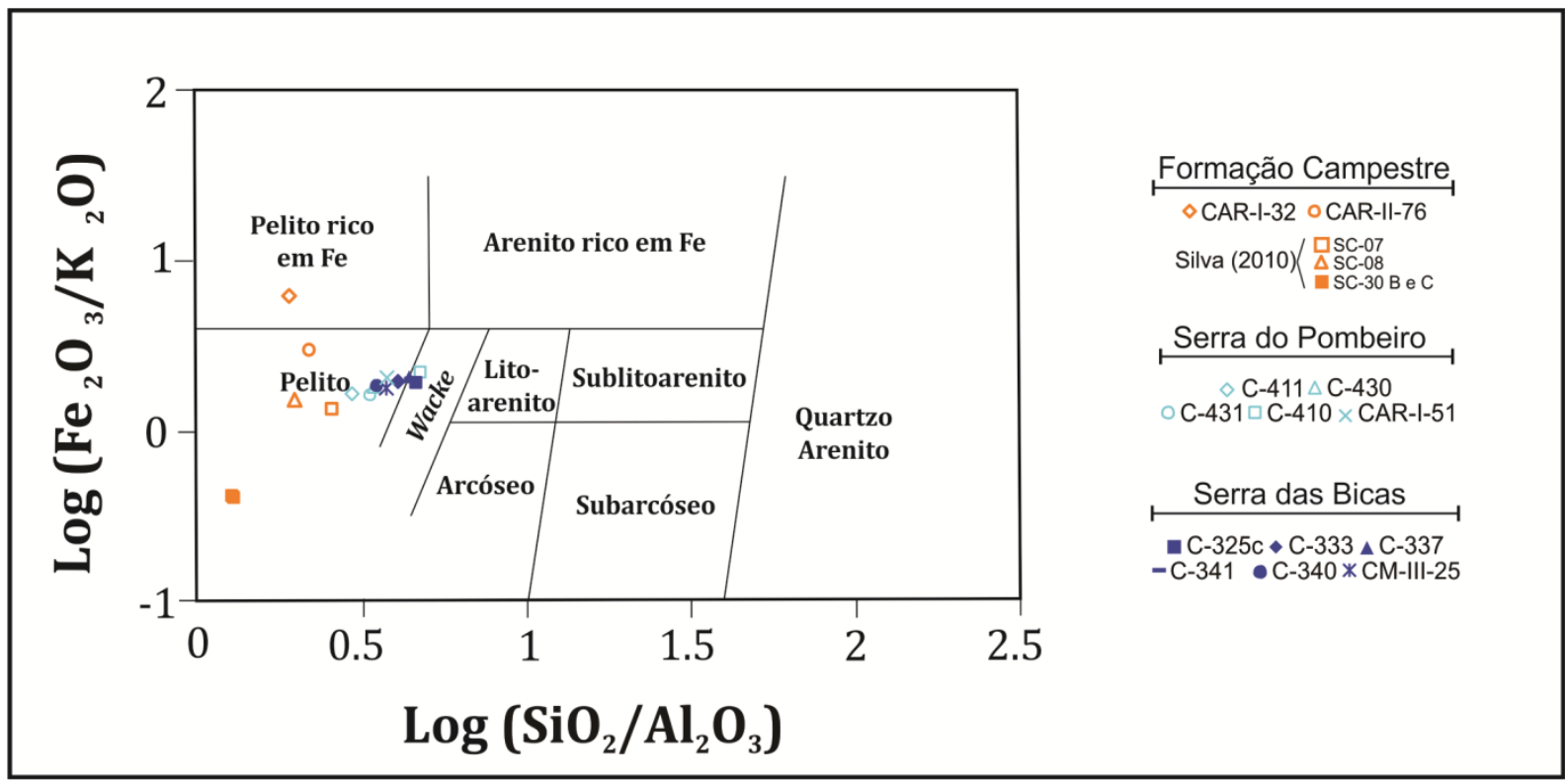

Figura X.2: amostras da unidade UBX e grafita-muscovita xisto da FC plotadas no diagrama de classificação química de arenitos segundo Herron (1988).

\begin{tabular}{cc}
\hline Amostra & CIA \\
\hline UBX & 58,41 a 70,26 \\
\hline CAR-I-32 & 88,72 \\
\hline CAR-II-76 & 82,75 \\
\hline SC-07 & 78,85 \\
\hline SC-08 & 80,96 \\
\hline SC-30B & 76,15 \\
\hline SC-30C & 76,00 \\
\hline
\end{tabular}

Tabela X.2: valores de CIA para as amostras do grafita- muscovita xisto analisadas neste trabalho e por Silva (2010). $\mathrm{CIA}=\left[\mathrm{Al}_{2} \mathrm{O}_{3} /\left(\mathrm{Al}_{2} \mathrm{O}_{3}+\mathrm{CaO}+\mathrm{Na}_{2} \mathrm{O}+\mathrm{K}_{2} \mathrm{O}\right)\right] * 100$; óxidos em proporção molecular.

Os índices de alteração química são menores para as amostras ricas em alumínio da região da Serra das Bicas provavelmente porque estas são extremamente enriquecidas em potássio, elemento químico que tende a se concentrar em argilominerais. $\mathrm{O}$ enriquecimento 
em potássio pode estar relacionado com fontes ricas em feldspato potássico, ou com formação de argilominerais autigênicos na diagênese.

\section{X.2. Geoquímica de elementos traços}

Os valores obtidos para elementos traço pelos métodos de FRX e ICP-MS e suas respectivas razões e valores normalizados (condrito Taylor e McLennan, 1985) estão apresentados nas tabelas X.3 e X.4.

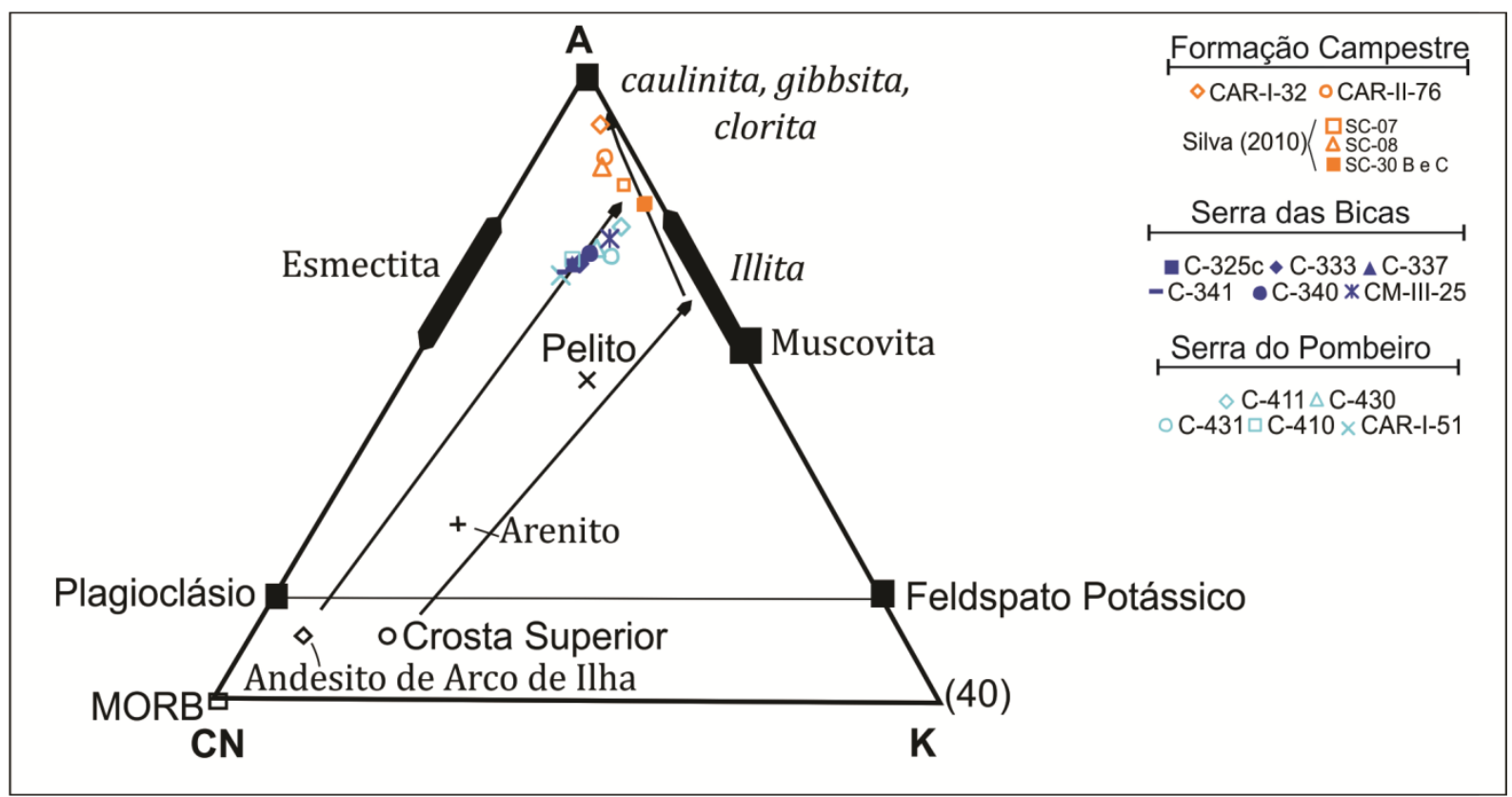

Figura X.3: amostras analisadas plotadas no diagrama ternário da fração molar de $\mathrm{Al}_{2} \mathrm{O}_{3}(\mathrm{~A})-\mathrm{CaO}+\mathrm{Na}_{2} \mathrm{O}$ em silicatos $(\mathrm{CN})-\mathrm{K}_{2} \mathrm{O}(\mathrm{K})$ extraído, modificado e traduzido de McLennan et al. (1990).

Apesar de os teores de Zr e Hf dos grafita-muscovita xistos analisados apresentarem correlação positiva com $\mathrm{SiO}_{2}$, sugerindo que zircão sofreu fracionamento hidrodinâmico como na unidade UBX, apenas duas amostras foram analisadas, portanto padrões destes elementos químicos traço não devem ser estabelecidos com segurança.

No diagrama spider (figura X.4) o grafita-muscovita xisto apresenta empobrecimento em $\mathrm{Cs}, \mathrm{Rb}, \mathrm{Nb}, \mathrm{Sr}, \mathrm{Hf}, \mathrm{Zr}$ e ETRP e enriquecimento em Th, U, La, Ce, Nd e Sm. O empobrecimento em Hf, $\mathrm{Zr}$ e ETRP sugere fracionamento de minerais pesados no sedimento pelítico, concentrado em frações arenosas correlatas, durante períodos de alta energia, ou constante retrabalhamento do depósito, por um longo período de tempo, se em ambiente de menor energia. 
Destacam-se menores concentrações de $\mathrm{Rb}$ e $\mathrm{Ba}$, apesar da relativamente alta concentração de K. Provavelmente aqueles elementos foram solubilizados durante o intemperismo químico.

Quando comparadas as unidades, as amostras FC apresentam menores teores de Cs, $\mathrm{Rb}, \mathrm{Tm}$ e Yb e maiores concentrações de Th, U, Nb e Ce.

\begin{tabular}{|c|c|c|}
\hline & CAR-I-32 & CAR-II-76 \\
\hline Co & 21,6 & 18,2 \\
\hline $\mathrm{Cr}$ & 110,8 & 144,9 \\
\hline $\mathrm{Cu}$ & 26,2 & 14,8 \\
\hline Ga & 35,5 & 33,3 \\
\hline $\mathbf{N i}$ & 20,2 & 30,4 \\
\hline $\mathbf{P b}$ & 19,3 & 24,3 \\
\hline $\mathbf{R b}$ & 82,3 & 126,6 \\
\hline Sc & 17,6 & 19,2 \\
\hline Th & 21,10 & 14,60 \\
\hline V & 144,3 & 151,8 \\
\hline Zn & 121,5 & 96,2 \\
\hline $\mathbf{Z r}$ & 165,5 & 180,1 \\
\hline Th/Sc & 1,20 & 1,10 \\
\hline $\mathrm{Cr} / \mathrm{V}$ & 0,77 & 0,95 \\
\hline
\end{tabular}

Tabela X.3: razões e concentrações de elementos traço obtidas pelo método de FRX para as amostras do grafitamuscovita xisto da Formação Campestre. 


\begin{tabular}{|c|c|c|}
\hline & CAR-I-32 & CAR-II-76 \\
\hline $\mathrm{Sr}$ & 94,06 & 131,28 \\
\hline $\mathrm{Y}$ & 19,56 & 12,36 \\
\hline $\mathrm{Nb}$ & 23,50 & 15,40 \\
\hline Cs & 1,47 & 3,02 \\
\hline $\mathrm{Ba}$ & 299,06 & 408,39 \\
\hline La & 70,47 & 37,96 \\
\hline $\mathrm{Ce}$ & 160,51 & 113,27 \\
\hline $\operatorname{Pr}$ & 13,74 & 8,26 \\
\hline $\mathrm{Nd}$ & 49,53 & 30,07 \\
\hline Sm & 8,16 & 5,21 \\
\hline $\mathrm{Eu}$ & 1,74 & 1,11 \\
\hline Gd & 5,34 & 3,39 \\
\hline $\mathrm{Tb}$ & 0,69 & 0,45 \\
\hline Dy & 3,35 & 2,12 \\
\hline Ho & 0,60 & 0,39 \\
\hline Er & 1,62 & 1,04 \\
\hline Tm & 0,22 & 0,14 \\
\hline $\mathbf{Y b}$ & 1,42 & 0,90 \\
\hline Lu & 0,21 & 0,13 \\
\hline Hf & 4,13 & 4,49 \\
\hline $\mathbf{P b}$ & 14,44 & 20,59 \\
\hline Th & 21,81 & 14,81 \\
\hline $\mathbf{U}$ & 4,94 & 3,88 \\
\hline $\mathbf{L a}_{\mathbf{N}}$ & 128,00 & 68,95 \\
\hline $\mathrm{Ce}_{\mathrm{N}}$ & 111,82 & 78,91 \\
\hline $\operatorname{Pr}_{N}$ & 66,84 & 40,19 \\
\hline $\mathbf{N d}_{\mathbf{N}}$ & 46,44 & 28,19 \\
\hline $\mathrm{Sm}_{\mathrm{N}}$ & 23,55 & 15,05 \\
\hline $\mathbf{E u}_{\mathbf{N}}$ & 13,32 & 8,49 \\
\hline $\mathbf{G d}_{\mathbf{N}}$ & 11,63 & 7,39 \\
\hline $\mathbf{T} \mathbf{b}_{N}$ & 7,93 & 5,15 \\
\hline $\mathrm{Dy}_{\mathrm{N}}$ & 5,86 & 3,72 \\
\hline $\mathrm{Ho}_{\mathrm{N}}$ & 4,72 & 3,06 \\
\hline $\mathbf{E r}_{N}$ & 4,34 & 2,79 \\
\hline $\mathbf{T m}_{N}$ & 4,12 & 2,68 \\
\hline $\mathbf{Y} \mathbf{b}_{\mathrm{N}}$ & 3,83 & 2,42 \\
\hline $\mathbf{L} \mathbf{u}_{\mathbf{N}}$ & 3,67 & 2,33 \\
\hline$\overline{\Sigma \text { ETR }}$ & 494,71 & 349,39 \\
\hline$\Sigma$ ETRL & 376,65 & 231,29 \\
\hline$\Sigma$ ETRP & 46,10 & 29,54 \\
\hline $\mathbf{E u}_{\mathbf{N}} / \mathbf{E} \mathbf{u}^{*}$ & 0,81 & 0,80 \\
\hline $\mathbf{L a}_{N} / \mathbf{Y b}_{\mathbf{N}}$ & 33,43 & 28,50 \\
\hline $\mathrm{La}_{\mathrm{N}} / \mathrm{Sm}_{\mathrm{N}}$ & 5,44 & 4,58 \\
\hline $\mathbf{G d}_{\mathrm{N}} / \mathbf{Y b}_{\mathrm{N}}$ & 3,04 & 3,05 \\
\hline
\end{tabular}

Tabela X.4: razões e concentrações de elementos traço obtidas pelo método de ICP-MS para as amostras do grafita-muscovita xisto da Formação Campestre. 


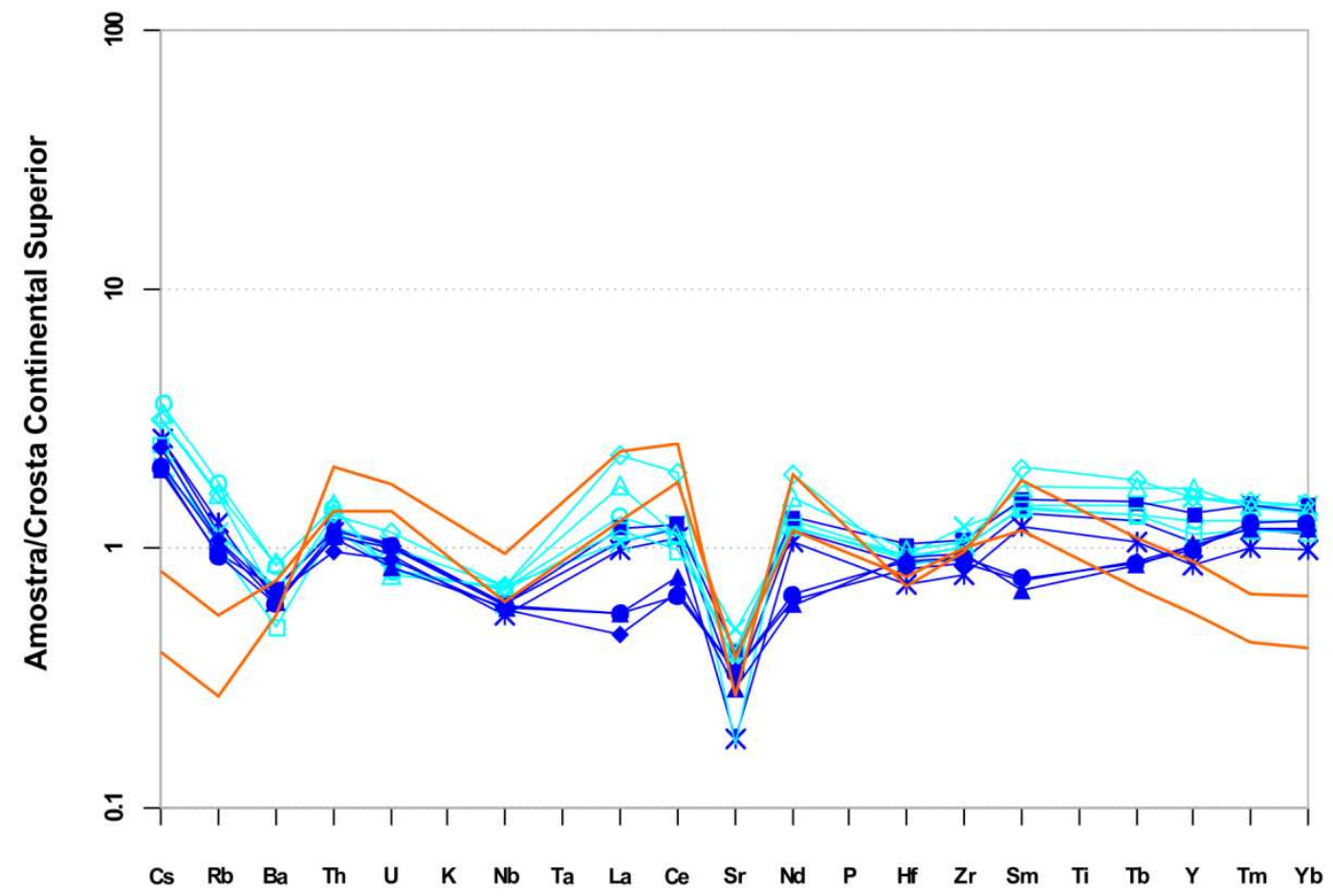

Figura X.4: diagrama spider das concentrações de elementos traço das amostras do grafita-muscovita xisto da FC (laranja) e da unidade UBX (azul claro e escuro), normalizado segundo os valores médios da crosta continental superior sugeridos por Taylor e McLennan (1995).

\section{X.2.1. Elementos Terras Raras (ETR)}

Os padrões de ETR indicam diferenças marcantes de assinatura entre as rochas destas unidades (figura X.5).

As amostras CAR-I-32 e CAR-II-76 apresentam forte fracionamento de ETR $\left(\mathrm{La}_{\mathrm{N}} / \mathrm{Yb}_{\mathrm{N}}=33,43-28,50\right)$, de ETRP $\left(\mathrm{Gd}_{\mathrm{N}} / \mathrm{Yb}_{\mathrm{N}}=3,04\right.$ e 3,05), ETRL $\left(\mathrm{La}_{N} / \mathrm{Sm}_{\mathrm{N}}=5,44-\right.$ 4,58) e anomalia negativa de Eu de 0,805 para ambas amostras. Os valores de ETRL são maiores e os de ETRP menores do que aqueles sugeridos para a crosta continental superior pós-Arqueana (PAAS e NASC).

Anomalias de Eu baixas sugerem que rochas geradas por processos de diferenciação na crosta, relacionadas com cristalização fracionada de plagioclásio, não foram tão importantes na proveniência dos sedimentos precursores do grafita-muscovita xisto quanto na unidade UBX, mas atuaram de maneira secundária vista a anomalia de Sr no diagrama spider. Entretanto, como se tratam de metapelitos, deve-se considerar o fracionamento de minerais 
pesados durante os processos de deposição sedimentar, o que causaria o empobrecimento em ETRP nas rochas pelíticas ocasionando forte fracionamento de ETR.

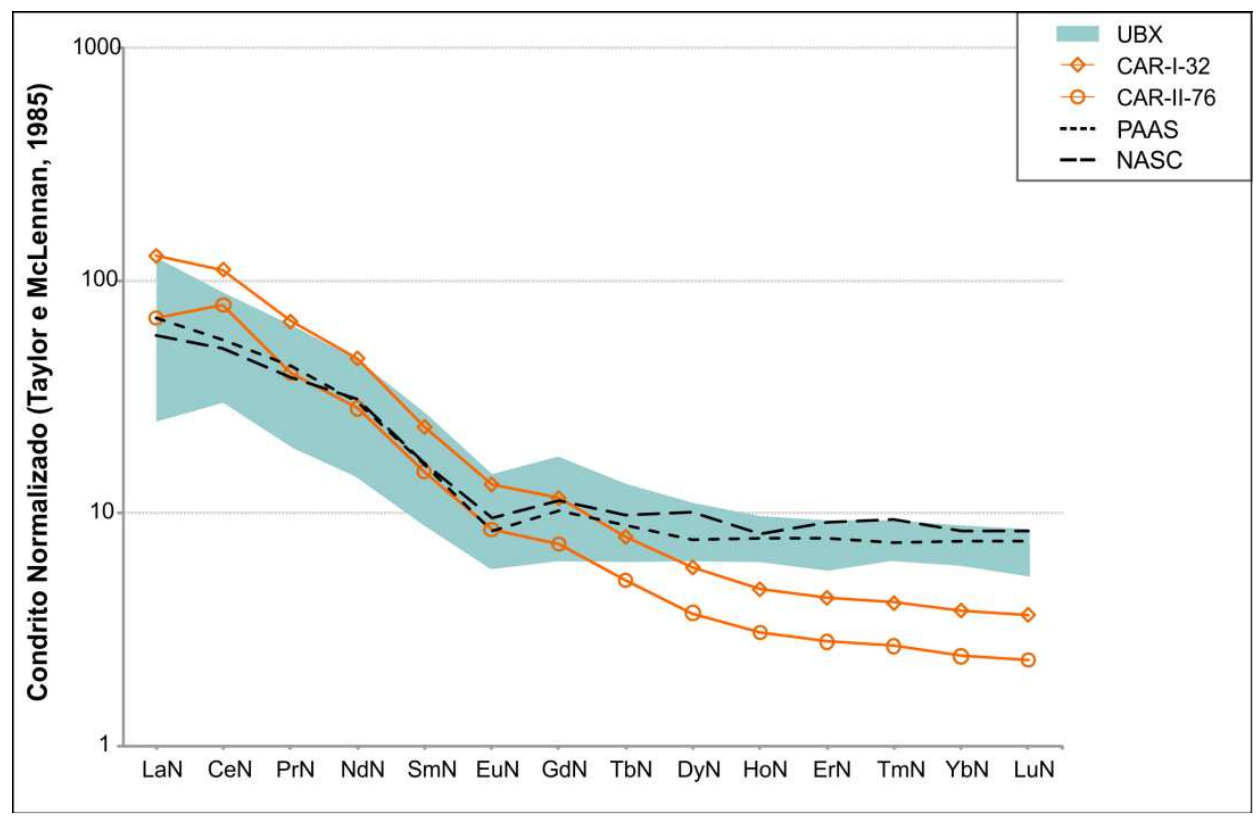

Figura X.5: Diagrama com normalização condrito de Taylor \& McLennan (1985) mostrando o padrão de Elementos Terras Raras das amostras do xisto grafitos em comparação com as amostras da unidade UBX analisadas e com os valores médios da crosta superior PAAS e NASC.

\section{X.2.2. Razões $\mathrm{Th} / \mathrm{Sc}$ e $\mathrm{Cr} / \mathrm{V}$}

Os valores das razões $\mathrm{Th} / \mathrm{Sc}$ e $\mathrm{Cr} / \mathrm{V}$ (figura X.7) para as amostras CAR-I-32 e CARII-76 foram muito variados, não permitindo uma caracterização da assinatura geoquímica da área-fonte do sedimento (CAR-I-32: Th/Sc $=1,24$ e $\mathrm{Cr} / \mathrm{V}=0,76 ; \mathrm{CAR}-\mathrm{II}-76: \mathrm{Th} / \mathrm{Sc}=0,77 \mathrm{e}$ $\mathrm{Cr} / \mathrm{V}=0,95)$. Entretanto, pode-se observar que a amostra que possui maior razão $\mathrm{Th} / \mathrm{Sc}$ apresenta menor razão Cr/V e maior valor para CIA, em relação à outra. 


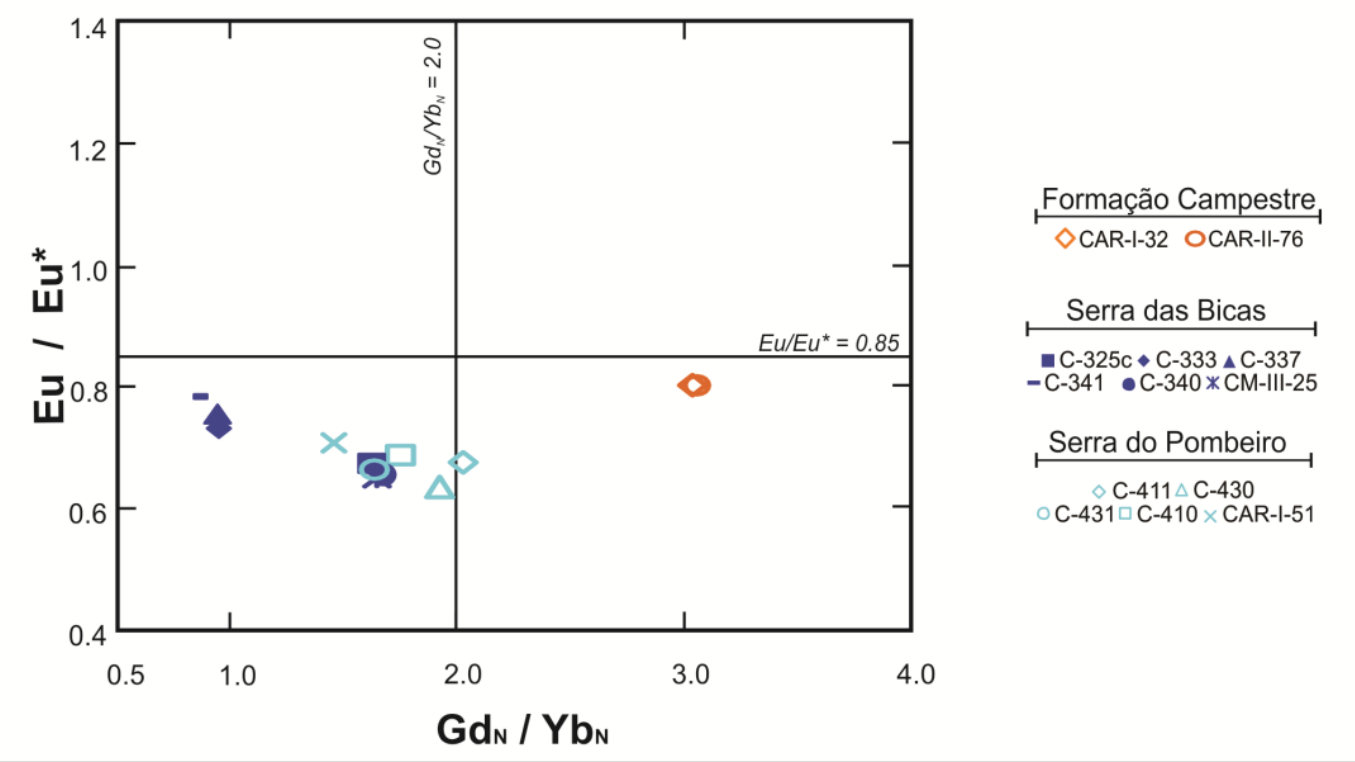

Figura X.6: gráfico de fracionamento de ETRP vs. Anomalia de Eu com as amostras do grafita-muscovita xisto da FC. As amostras da unidade UBX foram plotadas para comparação. Para linhas Eu/Eu* $=0,85$ e $\mathrm{Gd}_{\mathrm{N}} / \mathrm{Yb}_{\mathrm{N}}=$ 2,0 veja capítulo VI.

Comparadas às amostras da unidade UBX as amostras FC também apresentam valores para a razão $\mathrm{Th} / \mathrm{Sc}$ próximos de 1,0 e para a razão $\mathrm{Cr} / \mathrm{V}$ menor do que 1,0 , o que indica que rochas máfico-ultramáficas não foram importantes na proveniência dos sedimentos.

\section{X.2.3. Reciclagem sedimentar}

Os valores de Hf obtidos para as amostras CAR-I-32 e CAR-II-76 (tabela X.3) são semelhantes aos valores para a crosta continental superior (capítulo III - tabela III.8).

Com base nas relações $\mathrm{Th} / \mathrm{Sc}$ vs $\mathrm{Zr} / \mathrm{Sc}$, as amostras da $\mathrm{FC}$, assim como da UBX, não registram influência de processos de reciclagem sedimentar (figura X.8), pois não houve enriquecimento e concentração de minerais pesados, indicado pelas razões unitárias obtidas (e pela ausência de anomalia em Hf). 

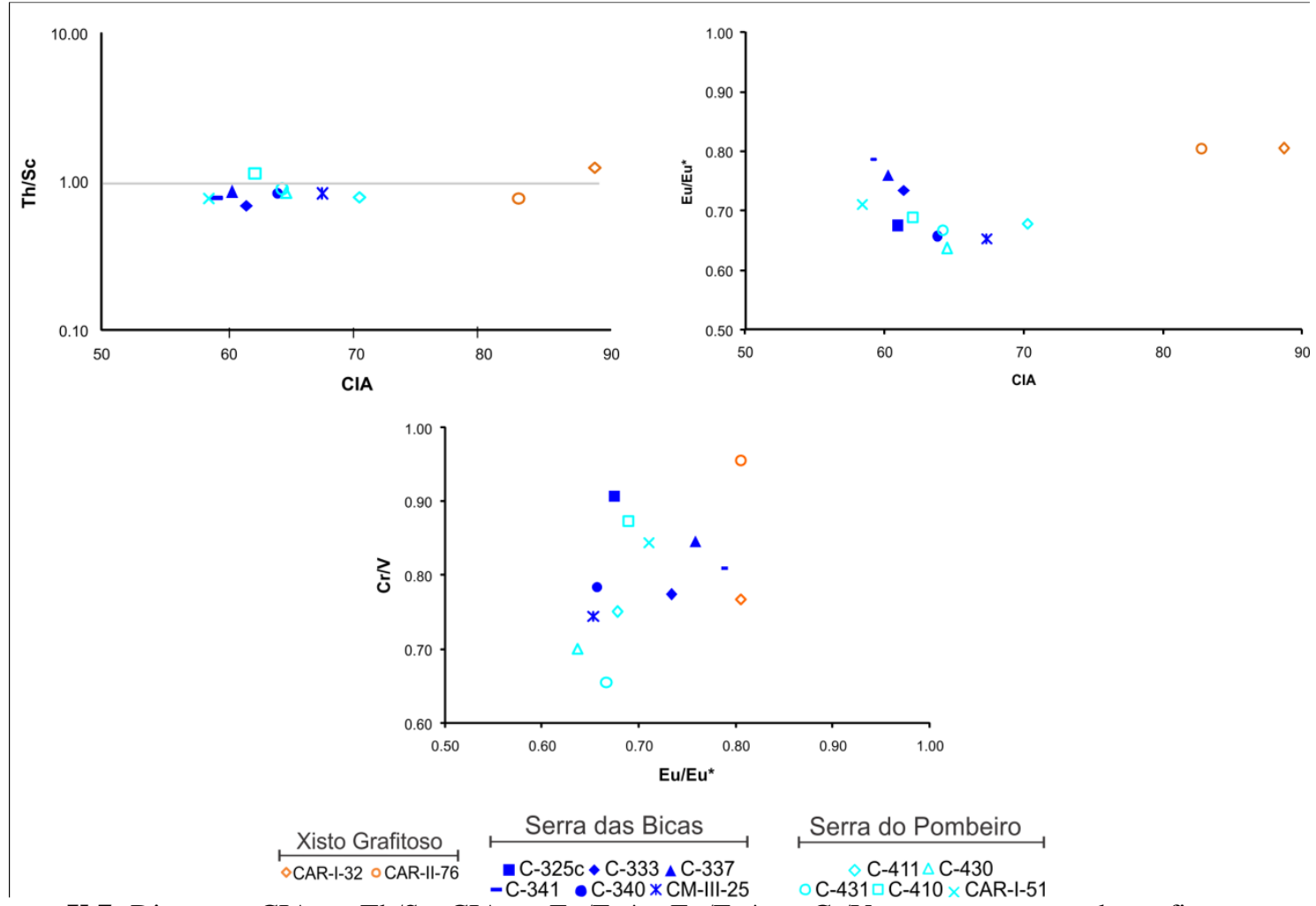

Figura X.7: Diagrama CIA vs. Th/Sc, CIA $v s$. Eu/Eu* e Eu/Eu* vs. Cr/V para as amostras do grafita-muscovita xisto e da unidade UBX.

\begin{tabular}{cccc}
\hline & Hf (ppm) & Zr/Sc & Th/Sc \\
\hline UBX & 4,18 a 5,94 & 10,14 a 13,95 & 0,68 a 1,13 \\
\hline CAR-I-32 & 4,13 & 9,40 & 1,20 \\
\hline $\begin{array}{c}\text { CAR-II-76 } \\
\text { Crosta Continental }\end{array}$ & 4,49 & 9,38 & 1,10 \\
\hline $\begin{array}{c}\text { Crosta Continental } \\
\text { Média }\end{array}$ & $5,8^{\mathrm{A}}$ & $14,0^{\mathrm{A}}$ & $0,79^{\mathrm{A}}$ \\
\hline $\begin{array}{c}\text { Crosta Continental } \\
\text { Inferior }\end{array}$ & $5,3^{\mathrm{B}}$ & $12,0^{\mathrm{B}}$ & $0,64^{\mathrm{B}}$ \\
\hline & $2,4^{\mathrm{C}}$ & $13,8^{\mathrm{C}}$ & $0,75^{\mathrm{C}}$ \\
\hline & $2,1^{\mathrm{A}}$ & $7,8^{\mathrm{C}}$ & $0,34^{\mathrm{C}}$ \\
\hline
\end{tabular}


Tabela X.3: valores das razões $\mathrm{La} / \mathrm{Sc}, \mathrm{Th} / \mathrm{Sc}$ e $\mathrm{Zr} / \mathrm{Sc}$ para as amostras do grafita-muscovita xisto analisadas e valores de referência para crosta continental superior, média e inferior. A: Taylor e McLennan (1985, 1995,

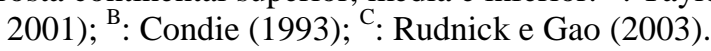
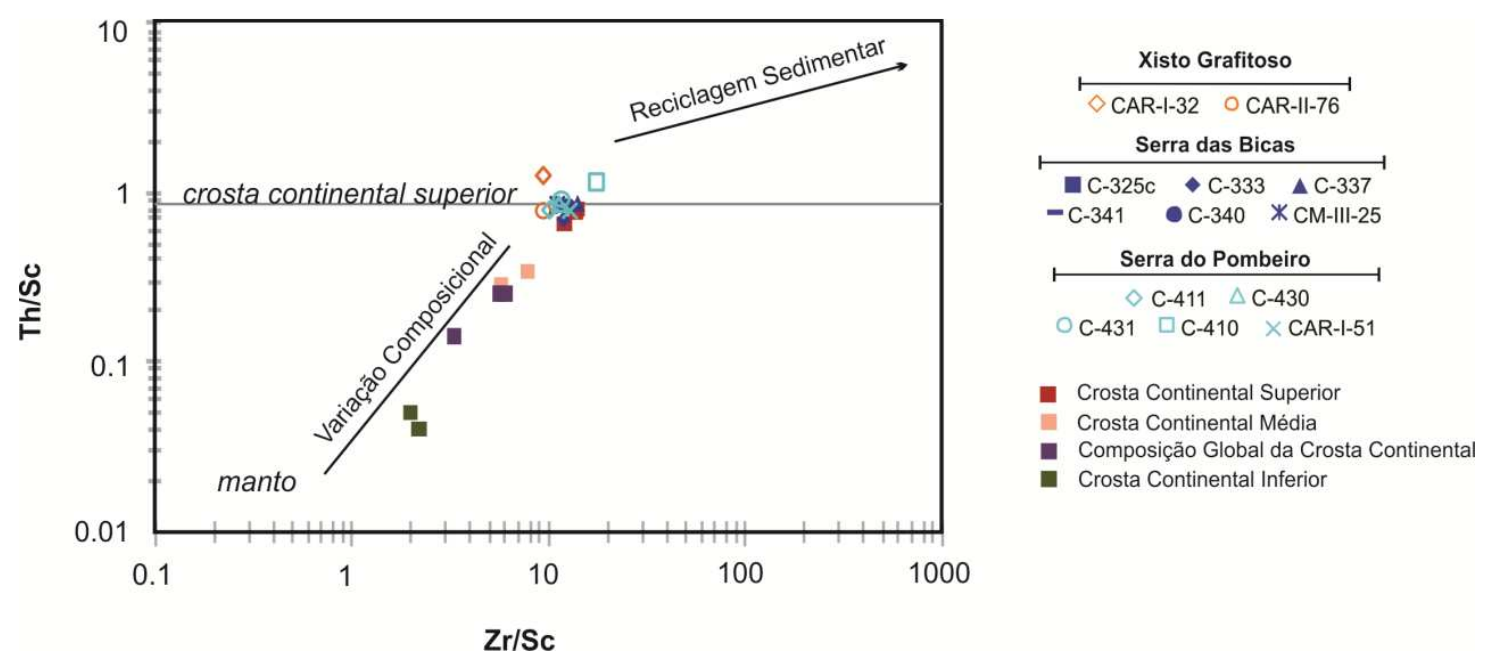

Figura X.8: gráfico Zr/Sc vs. Th/Sc extraído de McLennan et al. (1993) para as amostras do grafita-muscovita xisto e da unidade UBX que mostra a intensidade da reciclagem sedimentar do sedimento e a sua composição em relação às composições do manto e da crosta continental superior. Valores médios para a crosta continental superior, média, inferior e para a composição global da crosta continental sugeridos por Taylor e McLennan (1985, 1995, 2001), Condie (1993), Rudnick e Fountain (1995) e Rudnick e Gao (2003) foram plotados para comparação.

\section{X.3. Assinatura isotópica}

Três amostras do grafita-muscovita xisto (CAR-I-32, CAR-II-72 e CAR-IX-11) foram analisadas para obtenção das razões isotópicas ${ }^{87} \mathrm{Sr} /{ }^{86} \mathrm{Sr}$, entretanto, apenas duas destas, por terem sido encaminhadas para a FRX, apresentam dados de concentrações de $\mathrm{Rb}$ e $\mathrm{Sr}$ em ppm, o que limitou em duas amostras os dados isotópicos da razão ${ }^{87} \mathrm{Rb} /{ }^{86} \mathrm{Sr}$ dificultando o estabelecimento de idades relativas por este método.

Os dados obtidos para a razão ${ }^{87} \mathrm{Sr} /{ }^{86} \mathrm{Sr}$ foram maiores e da razão ${ }^{87} \mathrm{Rb} /{ }^{86} \mathrm{Sr}$ menores do que os obtidos para a unidade UBX (tabela X.7), o que sugere que as amostras da FC tiveram um maior período de residência crustal. A amostra CAR-I-32 apresentou perda de Rb, provavelmente devido à alteração química durante intemperismo, pois esta possui o maior valor de CIA $(88,72)$ entre as amostras do grafita-muscovita xisto.

Os valores da razões isotópicas, das idades modelo, $\varepsilon \mathrm{Nd}_{\mathrm{TDM}}$ para as amostras do grafita-muscovita xisto da FC (CAR-I-32, CAR-II-76 e CAR-IX-11) são apresentados nas 
tabelas X.8 e X.9. Os valores de $\varepsilon N d$ foram recalculados para $590 \mathrm{Ma}$, idade obtida por Campos Neto et al. (2011) e Valeriano et al. (2004) para o metamorfismo regional.

O grafita-muscovita xisto apresenta valores de $\mathrm{Sm}_{\mathrm{ppm}}, \mathrm{Nd}_{\mathrm{ppm}}, \varepsilon_{(\mathrm{o})}$ e idades modelo $\mathrm{T}_{\mathrm{DM}}$ maiores, valores para ${ }^{147} \mathrm{Sm} /{ }^{144} \mathrm{Nd},{ }^{143} \mathrm{Nd} /{ }^{144} \mathrm{Nd}$ e $\varepsilon_{\mathrm{TDM}}$ menores e $\varepsilon_{590}$ mais negativos do que os apresentados pelas amostras da unidade UBX.

As idades modelo $\mathrm{T}_{\mathrm{DM}}$ variam de 2,05 a $2,46 \mathrm{Ga}$ (figura X.9) e os valores de $\varepsilon \mathrm{Nd}_{590}$, fortemente negativos, estão no intervalo entre -18,47 e -15,99.

\begin{tabular}{|c|c|c|c|c|c|c|}
\hline & Rb (ppm) & Sr (ppm) & ${ }^{87} \mathrm{Sr} /{ }^{86} \mathrm{Sr}$ & $\operatorname{erro}(2 \sigma)$ & ${ }^{87} \mathrm{Rb} /{ }^{86} \mathrm{Sr}$ & ${ }^{87} \mathrm{Sr} /{ }^{86} \mathrm{Sr}_{590}$ \\
\hline UBX & $\begin{array}{c}121,80- \\
161,70\end{array}$ & $\begin{array}{l}67,70- \\
168,00\end{array}$ & $\begin{array}{c}0,7325- \\
0,7706\end{array}$ & - & $\begin{array}{c}2,2005- \\
6,4310\end{array}$ & $\begin{array}{c}0,7139- \\
0,7169\end{array}$ \\
\hline CAR-I-32 & 82,30 & 129,10 & 0,7473 & 0,00005 & 1,7163 & 0,7329 \\
\hline CAR-II-76 & 126,60 & 166,50 & 0,7493 & 0,00005 & 2,0473 & 0,7320 \\
\hline CAR-IX-11 & - & - & 0,7630 & 0,00007 & - & - \\
\hline
\end{tabular}

Tabela X.7: dados isotópicos e elementais do sistema Rb-Sr para as amostras do grafita-muscovita xisto da FC (em laranja). Valores obtidos para as amostras da unidade UBX foram colocados para comparação (em azul). ${ }^{87} \mathrm{Rb} /{ }^{86} \mathrm{Sr}=\left(\mathrm{Rb}_{\mathrm{ppm}} / \mathrm{Sr}_{\mathrm{ppm}}\right) * 2.8937 * 0,93047 ;{ }^{87} \mathrm{Sr} /{ }^{86} \mathrm{Sr}_{\mathrm{i}}={ }^{87} \mathrm{Sr} /{ }^{86} \mathrm{Sr}-{ }^{87} \mathrm{Rb} /{ }^{86} \mathrm{Sr}(\lambda \mathrm{t})$.

\begin{tabular}{|c|c|c|c|c|c|c|c|}
\hline Amostra & $\begin{array}{c}\text { Sm } \\
(\mathbf{p p m})\end{array}$ & Nd (ppm) & ${ }^{147} \mathrm{Sm} /{ }^{144} \mathrm{Nd}$ & erro $^{1}$ & ${ }^{143} \mathrm{Nd} /{ }^{144} \mathrm{Nd}$ & $\mathbf{T}_{\mathrm{DM}}$ (Ga) & $\varepsilon_{\text {(590Ма) }}$ \\
\hline UBX & $\begin{array}{l}3,685 \mathrm{a} \\
13,418\end{array}$ & $\begin{array}{c}18,901 \mathrm{a} \\
73,351\end{array}$ & $\begin{array}{c}0,1106 \mathrm{a} \\
0,1207\end{array}$ & - & $\begin{array}{c}0,5120 \mathrm{a} \\
0,5121\end{array}$ & $\begin{array}{c}1,550 \mathrm{a} \\
1,627\end{array}$ & $\begin{array}{c}-6,251 a \\
-5,472\end{array}$ \\
\hline CAR-I-32 & 15,599 & 97,337 & 0,097 & $1.2 * 10^{-5}$ & 0,5113 & 2,27 & $-18,47$ \\
\hline CAR-II-76 & 33,127 & 216,790 & 0,092 & $7.0 * 10^{-6}$ & 0,5114 & 2,05 & $-15,99$ \\
\hline CAR-IX-11 & 12,380 & 69,118 & 0,108 & $1.0 * 10^{-5}$ & 0,5114 & 2,46 & $-18,42$ \\
\hline
\end{tabular}

Tabela X.8: dados isotópicos e elementais do sistema Sm-Nd para as amostras do grafita-muscovita xisto da FC (em laranja). Valores obtidos para as amostras da unidade UBX foram colocados para comparação (em azul). Branco analítico para $\mathrm{Sm}=47$ pg e para $\mathrm{Nd}=114$; Razão isotópica ${ }^{147} \mathrm{Sm} /{ }^{144} \mathrm{Nd}$ calculada a partir da equação: $=[($ Conc Sm/Conc Nd $) * 0,604491]$; Razões isotópicas ${ }^{143} \mathrm{Nd} /{ }^{144} \mathrm{Nd}$ normalizadas para o valor de 0,7219

(DePaolo, 1981); Valor médio para a razão ${ }^{143} \mathrm{Nd} /{ }^{144} \mathrm{Nd}$ do padrão JNdi $=0,512100 \pm 0,000004$; Idade Modelo $\mathrm{T}_{\mathrm{DM}}$ calculada pela equação: $=\left\{\left[\left({ }^{143} \mathrm{Nd} /{ }^{144} \mathrm{Nd}\right)_{\mathrm{am}} / 0,512638\right]-1\right\} * 10^{4}$, onde ${ }^{143} \mathrm{Nd} /{ }^{144} \mathrm{Nd} \mathrm{CHUR}_{\mathrm{C}}=0,512638$ (Hamilton et al., 1983); eNd(0) corresponde ao valor atual $(\mathrm{t}=0)$ e é calculado segundo a equação: $=$ $\left\{\left[\left({ }^{143} \mathrm{Nd} /{ }^{144} \mathrm{Nd}\right)_{\mathrm{am}} / 0,512638\right]-1\right\} * 10^{4}$. 
Considerando que idades-modelo de rochas sedimentares representam a mistura de diferentes rochas presentes na área-fonte (McCulloch e Wasseburg, 1978) e que o sistema Sm-Nd não sofre alterações significativas durante o metamorfismo, as idades $\mathrm{T}_{\mathrm{DM}}$ obtidas no Paleoproterozóico indicam que a área-fonte dos sedimentos precursores do grafita-muscovita xisto era composta por rochas mais antigas que as que originaram as rochas da unidade UBX. Valores de $\varepsilon_{\mathrm{Nd}}$ entre $-18,47$ e $-15,99$ para 590 Ma confirmam a longa residência na crosta do $\mathrm{Nd}$.

A figura X.10 mostra gráficos elaborados por diversos autores para a classificação quanto ao ambiente tectônico de deposição de rochas sedimentares. Destaca-se uma proveniência de crosta continental superior com componente de crosta antiga associado $\left(\varepsilon_{\mathrm{Nd}}\right.$ fortemente negativo e altos valores para a razão ${ }^{87} \mathrm{Sr} /{ }^{86} \mathrm{Sr}$ ), diferenciando-as da unidade UBX que apresenta compatibilidade química com sedimentos gerados a partir da erosão de crosta continental superior e de arco magmático (figuras X.10 A e B).

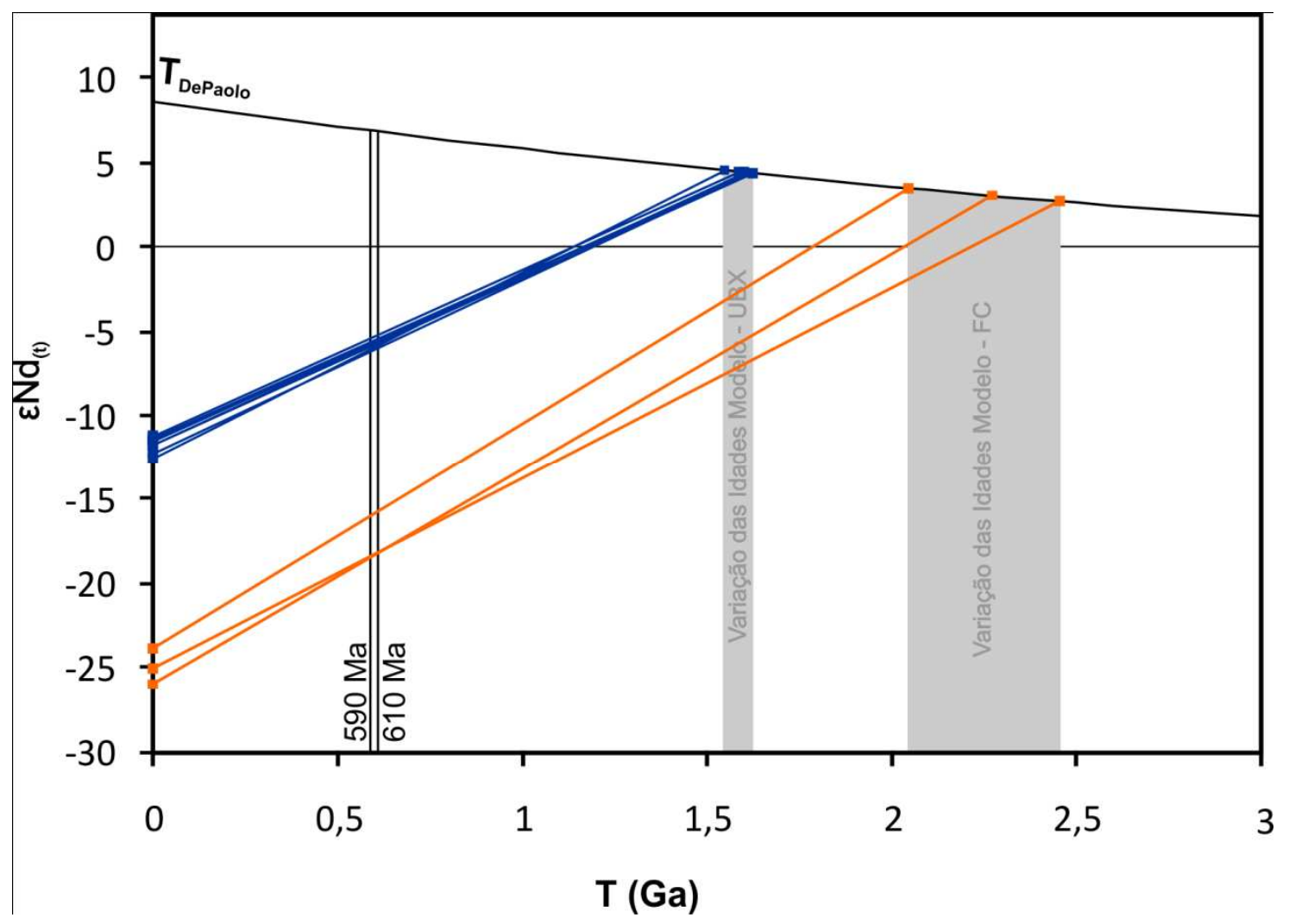

Figura X.9: gráfico $\mathrm{T}(\mathrm{Ga})$ vs. $\varepsilon \mathrm{Nd}_{(\mathrm{t})}$ para as amostras do grafita-muscovita xisto da FC (em laranja). Valores da unidade UBX foram colocados para comparação (em azul). Dados de $\varepsilon N d$ (t) recalculados para 590 e $610 \mathrm{Ma}$. 


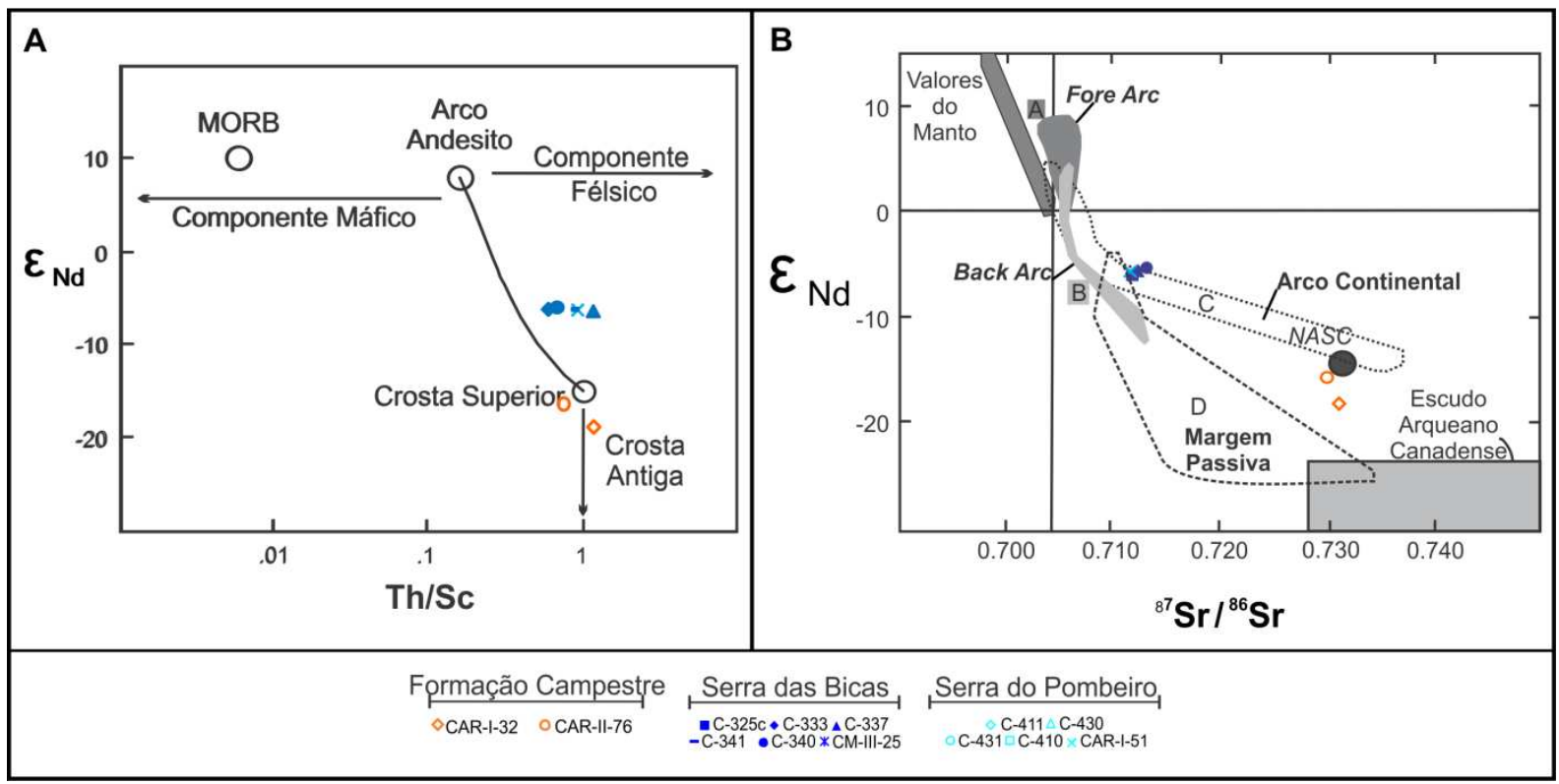

Figura X.10: diagramas de classificação química segundo o ambiente tectônico de deposição. દNd e razões

${ }^{87} \mathrm{Sr} /{ }^{86} \mathrm{Sr}$ foram recalculados para $590 \mathrm{Ma}$ (idade do metamorfismo). Gráficos extraídos e traduzidos de McLennan et al. (1990).

\section{X.4. U-Pb em cristais de zircão detrítico}

A amostra CAR-II-179 pertencente a um quartzito lenticular nos grafita-muscovita xistos do topo da Formação Campestre, em uma zona de charneira sinformal na Serra do Pombeiro, foi preparada para separação de cristais de zircão detríticos.

Os cristais variam de 65 a $200 \mu \mathrm{m}$, sendo que a maioria apresenta zoneamento de crescimento episódico concêntrico e truncado, com cristais arredondados predominantes sobre os prismáticos e subarredondados. Alguns grãos apresentam uma auréola sobrecrescida, sem zoneamento interno e irregular, com espessuras que chegam a $18 \mu \mathrm{m}$. Ocorrem, subordinadamente, cristais com zoneamento paralelo ao eixo $\mathrm{C}$ e com padrão irregular de alternância entre bandas claras e escuras, por vezes convergentes.

Foram separados 128 cristais de zircão (figura X.11) e 91 pontos (figura X.12) de análises por U-Pb LA-MC-ICPMS foram realizados. Destes, 51\% apresentaram valores de concordância entre acima de 90\% (tabelas X.10 e X.11).

As análises pontuais em cristais metamíticos, com coloração amarelada e intensamente fraturados, indicaram baixa concordância (abaixo de 80\%) e perda de $\mathrm{Pb}$.

As figuras X.13 A e B mostram a distribuição dos cristais de zircão do quartzito da FC, com predomínio de cristais com idade ${ }^{206} \mathrm{~Pb} /{ }^{207} \mathrm{~Pb}$ no Mesoproterozóico entre 1576 e $1020 \mathrm{Ma}(55 \%$ dos dados, $60 \%$ destes entre 1450 e $1150 \mathrm{Ma})$, e no Paleoproterozóico entre 2455 e $1766 \mathrm{Ma}(36.6 \%$ dos dados, dos quais 40\% entre 2104 e $2216 \mathrm{Ma})$. Dois cristais 
forneceram idades no Neoproterozóico de $882 \pm 49$ Ma e $798 \pm 79$ Ma e outros três cristais apresentaram idades no Arqueano de $2751 \pm 50 \mathrm{Ma}, 2631 \pm 50 \mathrm{Ma}$ e $2626 \pm 37 \mathrm{Ma}$.

\begin{tabular}{|c|c|c|c|c|c|c|c|}
\hline Ponto & ${ }^{207} \mathrm{~Pb} /{ }^{235} \mathrm{U}$ & 2s error & ${ }^{206} \mathrm{~Pb} /{ }^{238} \mathrm{U}$ & $\begin{array}{c}2 s \\
\text { error }\end{array}$ & ${ }^{207} \mathrm{~Pb} /{ }^{206} \mathrm{~Pb}$ & 2s error & rho \\
\hline 1.1 & 5,02540 & 0,22107 & 0,33333 & 0,01429 & 0,1357 & 0,0034 & 0,948 \\
\hline 2.1 & 5,73263 & 0,29301 & 0,32664 & 0,01449 & 0,1100 & 0,0011 & 0,846 \\
\hline 3.1 & 5,00851 & 0,22465 & 0,27350 & 0,01185 & 0,1347 & 0,0016 & 0,940 \\
\hline 4.1 & 2,58632 & 0,11465 & 0,22846 & 0,00981 & 0,0816 & 0,0009 & 0,943 \\
\hline 5.1 & 5,64146 & 0,25721 & 0,27358 & 0,01195 & 0,1511 & 0,0020 & 0,933 \\
\hline 6.1 & 5,03314 & 0,24533 & 0,32428 & 0,01507 & 0,1111 & 0,0016 & 0,931 \\
\hline 7.1 & 1,47393 & 0,15511 & 0,10640 & 0,01018 & 0,1043 & 0,0046 & 0,904 \\
\hline 8.1B & 3,75315 & 0,17321 & 0,28696 & 0,01236 & 0,0974 & 0,0016 & 0,908 \\
\hline 8.2B & 3,47889 & 0,15472 & 0,27146 & 0,01167 & 0,0950 & 0,0011 & 0,940 \\
\hline $8.3 \mathrm{~N}$ & 3,64234 & 0,16171 & 0,28438 & 0,01213 & 0,0923 & 0,0011 & 0,934 \\
\hline 9.1 & 1,64571 & 0,08447 & 0,15550 & 0,00695 & 0,0718 & 0,0018 & 0,849 \\
\hline 10.1 & 8,24707 & 0,54843 & 0,36303 & 0,02245 & 0,1618 & 0,0040 & 0,918 \\
\hline 11.1 & 2,80822 & 0,18365 & 0,21184 & 0,01232 & 0,0988 & 0,0030 & 0,876 \\
\hline 12.1 & 2,19230 & 0,08183 & 0,20342 & 0,00671 & 0,0791 & 0,0014 & 0,843 \\
\hline 13.1 & 3,07364 & 0,13806 & 0,24849 & 0,00952 & 0,0913 & 0,0021 & 0,824 \\
\hline 14.1 & 6,46497 & 0,21463 & 0,37133 & 0,01184 & 0,1263 & 0,0012 & 0,914 \\
\hline 15.1 & 2,68165 & 0,09588 & 0,22744 & 0,00732 & 0,0879 & 0,0014 & 0,857 \\
\hline 16.1 & 3,23294 & 0,11977 & 0,17066 & 0,00595 & 0,1436 & 0,0018 & 0,902 \\
\hline 17.1 & 6,21489 & 0,21601 & 0,36529 & 0,01213 & 0,1228 & 0,0013 & 0,912 \\
\hline 18.1 & 7,18359 & 0,23709 & 0,39611 & 0,01262 & 0,1315 & 0,0011 & 0,918 \\
\hline 19.1 & 4,76976 & 0,17427 & 0,28192 & 0,00986 & 0,1251 & 0,0013 & 0,918 \\
\hline 20.1 & 2,02167 & 0,09595 & 0,18723 & 0,00836 & 0,0775 & 0,0012 & 0,917 \\
\hline 21.1 & 2,00907 & 0,08069 & 0,18745 & 0,00646 & 0,0790 & 0,0016 & 0,823 \\
\hline 22.1 & 3,56809 & 0,12103 & 0,26944 & 0,00871 & 0,0959 & 0,0010 & 0,907 \\
\hline 23.1 & 6,20247 & 0,20644 & 0,36147 & 0,01160 & 0,1245 & 0,0011 & 0,917 \\
\hline 24.1 & 2,40114 & 0,08276 & 0,20943 & 0,00674 & 0,0837 & 0,0010 & 0,888 \\
\hline
\end{tabular}




\begin{tabular}{rccccccc}
\hline $\mathbf{2 5 . 1}$ & 7,17306 & 0,26256 & 0,39349 & 0,01293 & 0,1333 & 0,0021 & 0,856 \\
$\mathbf{2 6 . 1}$ & 7,31186 & 0,25706 & 0,40290 & 0,01305 & 0,1304 & 0,0018 & 0,878 \\
$\mathbf{2 7 . 1}$ & 3,17494 & 0,10793 & 0,24954 & 0,00793 & 0,0911 & 0,0011 & 0,889 \\
$\mathbf{2 8 . 1}$ & 3,19609 & 0,10804 & 0,25576 & 0,00810 & 0,0902 & 0,0011 & 0,890 \\
$\mathbf{2 9 . 1}$ & 4,83061 & 0,16779 & 0,29123 & 0,00932 & 0,1222 & 0,0017 & 0,876 \\
$\mathbf{3 0 . 1}$ & 1,88984 & 0,07624 & 0,14132 & 0,00520 & 0,1034 & 0,0017 & 0,878 \\
$\mathbf{3 1 . 1}$ & 4,78325 & 0,16605 & 0,31849 & 0,01031 & 0,1083 & 0,0014 & 0,888 \\
\hline $\mathbf{3 2 . 1}$ & 1,56261 & 0,06109 & 0,16575 & 0,00543 & 0,0684 & 0,0015 & 0,799 \\
$\mathbf{3 3 . 1}$ & 6,40775 & 0,22522 & 0,38154 & 0,01262 & 0,1241 & 0,0015 & 0,898 \\
$\mathbf{3 4 . 1}$ & 7,69706 & 0,30514 & 0,38509 & 0,01292 & 0,1487 & 0,0031 & 0,808 \\
\hline $\mathbf{3 5 . 1}$ & 10,47779 & 0,46308 & 0,46451 & 0,01838 & 0,1599 & 0,0032 & 0,867 \\
\hline $\mathbf{3 6 . 1}$ & 2,79838 & 0,11898 & 0,23505 & 0,00901 & 0,0867 & 0,0016 & 0,871 \\
$\mathbf{3 7 . 1}$ & 2,49605 & 0,09019 & 0,21857 & 0,00708 & 0,0809 & 0,0013 & 0,854 \\
$\mathbf{3 8 . 1}$ & 5,93469 & 0,23182 & 0,28115 & 0,00983 & 0,1545 & 0,0027 & 0,859 \\
$\mathbf{3 9 . 1}$ & 13,61964 & 0,59923 & 0,52517 & 0,02070 & 0,1911 & 0,0037 & 0,867 \\
\hline $\mathbf{4 0 . 1}$ & 2,81376 & 0,11710 & 0,23966 & 0,00894 & 0,0867 & 0,0016 & 0,864 \\
$\mathbf{4 1 . 1}$ & 2,99098 & 0,11702 & 0,24458 & 0,00849 & 0,0883 & 0,0016 & 0,851 \\
\hline
\end{tabular}

Continuação tabela X.10: razões ${ }^{207} \mathrm{~Pb} /{ }^{235} \mathrm{U},{ }^{206} \mathrm{~Pb} /{ }^{238} \mathrm{U},{ }^{207} \mathrm{~Pb}{ }^{1206} \mathrm{~Pb}$, seus respectivos erros $(1 \sigma)$ e os valores de rho da amostra C-431 da unidade UBX.

\begin{tabular}{|c|c|c|c|c|c|c|c|}
\hline Ponto & ${ }^{207} \mathrm{~Pb} /{ }^{235} \mathrm{U}$ & $2 s$ error & ${ }^{206} \mathrm{~Pb} /{ }^{238} \mathrm{U}$ & $\begin{array}{c}2 s \\
\text { error }\end{array}$ & ${ }^{207} \mathrm{~Pb} /{ }^{206} \mathrm{~Pb}$ & $2 s$ error & rho \\
\hline 42.1 & 2,83124 & 0,11203 & 0,23905 & 0,00847 & 0,0859 & 0,0015 & 0,859 \\
\hline 43.1 & 1,77236 & 0,07259 & 0,17534 & 0,00623 & 0,0732 & 0,0015 & 0,834 \\
\hline 44.1 & 1,08761 & 0,05657 & 0,12236 & 0,00455 & 0,0657 & 0,0024 & 0,689 \\
\hline 45.1 & 3,38806 & 0,15051 & 0,26460 & 0,01062 & 0,0937 & 0,0018 & 0,876 \\
\hline 46.1 & 0,93780 & 0,04536 & 0,09159 & 0,00392 & 0,0742 & 0,0017 & 0,862 \\
\hline 47.1 & 2,56242 & 0,13224 & 0,22305 & 0,01035 & 0,0854 & 0,0019 & 0,878 \\
\hline 48.1 & 2,74142 & 0,12969 & 0,22675 & 0,00916 & 0,0854 & 0,0021 & 0,828 \\
\hline 49.1 & 2,38478 & 0,11376 & 0,20791 & 0,00884 & 0,0832 & 0,0018 & 0,866 \\
\hline 50.1 & 2,20665 & 0,11547 & 0,20055 & 0,00888 & 0,0824 & 0,0023 & 0,824 \\
\hline 51.1 & 7,95140 & 0,35330 & 0,42256 & 0,01663 & 0,1391 & 0,0029 & 0,857 \\
\hline 52.1 & 10,59977 & 0,44398 & 0,43856 & 0,01617 & 0,1771 & 0,0035 & 0,848 \\
\hline 53.1 & 2,85295 & 0,11992 & 0,21781 & 0,00800 & 0,0965 & 0,0020 & 0,842 \\
\hline 54.1 & 1,94815 & 0,08366 & 0,15472 & 0,00554 & 0,0928 & 0,0022 & 0,802 \\
\hline 55.1 & 1,65078 & 0,06984 & 0,12845 & 0,00469 & 0,0934 & 0,0020 & 0,831 \\
\hline 56.1 & 3,62334 & 0,15422 & 0,27724 & 0,00978 & 0,0953 & 0,0023 & 0,796 \\
\hline 57.1 & 1,56321 & 0,08216 & 0,12705 & 0,00587 & 0,0870 & 0,0022 & 0,859 \\
\hline 58.1 & 2,10404 & 0,08982 & 0,19027 & 0,00693 & 0,0811 & 0,0018 & 0,821 \\
\hline 59.1 & 1,80246 & 0,08090 & 0,16800 & 0,00617 & 0,0760 & 0,0020 & 0,789 \\
\hline 60.1 & 1,46320 & 0,06381 & 0,13693 & 0,00521 & 0,0752 & 0,0016 & 0,842 \\
\hline 61.1 & 2,87875 & 0,12072 & 0,18892 & 0,00685 & 0,1121 & 0,0024 & 0,832 \\
\hline 62.1 & 6,58294 & 0,29263 & 0,36027 & 0,01431 & 0,1350 & 0,0027 & 0,865 \\
\hline 63.1 & 1,48118 & 0,08147 & 0,11193 & 0,00549 & 0,1002 & 0,0025 & 0,874 \\
\hline 64.1 & 5,50030 & 0,28617 & 0,34212 & 0,01758 & 0,1171 & 0,0010 & 0,969 \\
\hline 65.1 & 5,86608 & 0,30726 & 0,36016 & 0,01867 & 0,1192 & 0,0009 & 0,971 \\
\hline 66.1 & 6,85827 & 0,38539 & 0,36641 & 0,02023 & 0,1362 & 0,0014 & 0,966 \\
\hline
\end{tabular}




\begin{tabular}{|c|c|c|c|c|c|c|c|}
\hline 67.1 & 6,96288 & 0,35888 & 0,38434 & 0,01960 & 0,1334 & 0,0010 & 0,970 \\
\hline 68.1 & 6,69682 & 0,34739 & 0,36926 & 0,01892 & 0,1333 & 0,0011 & 0,969 \\
\hline 69.1 & 3,68239 & 0,22243 & 0,13766 & 0,00772 & 0,1925 & 0,0043 & 0,913 \\
\hline 70.1 & 2,55165 & 0,13624 & 0,16128 & 0,00843 & 0,1158 & 0,0013 & 0,961 \\
\hline 71.1 & 8,40822 & 0,47045 & 0,34055 & 0,01849 & 0,1804 & 0,0024 & 0,954 \\
\hline 72.1 & 3,29627 & 0,17101 & 0,22338 & 0,01138 & 0,1084 & 0,0011 & 0,963 \\
\hline 73.1 & 6,00504 & 0,36416 & 0,35915 & 0,02116 & 0,1229 & 0,0018 & 0,958 \\
\hline 74.1 & 4,20885 & 0,23344 & 0,28582 & 0,01477 & 0,1080 & 0,0022 & 0,915 \\
\hline 75.1 & 4,39267 & 0,23122 & 0,26159 & 0,01358 & 0,1256 & 0,0011 & 0,968 \\
\hline 76.1 & 1,88841 & 0,09563 & 0,17260 & 0,00864 & 0,0806 & 0,0006 & 0,969 \\
\hline 75.1 & 11,04614 & 0,62691 & 0,45991 & 0,02251 & 0,1777 & 0,0051 & 0,844 \\
\hline 76.1 & 3,18486 & 0,19663 & 0,20670 & 0,01016 & 0,1132 & 0,0042 & 0,780 \\
\hline 77.1 & 1,73290 & 0,09205 & 0,13950 & 0,00639 & 0,0959 & 0,0026 & 0,842 \\
\hline 78.1 & 3,63312 & 0,16552 & 0,27243 & 0,01037 & 0,0945 & 0,0024 & 0,807 \\
\hline 79.1 & 3,64799 & 0,16772 & 0,27392 & 0,01049 & 0,0952 & 0,0024 & 0,804 \\
\hline 80.1 & 2,24067 & 0,13868 & 0,13932 & 0,00761 & 0,1170 & 0,0034 & 0,868 \\
\hline 81.1 & 3,06021 & 0,13550 & 0,16670 & 0,00635 & 0,1373 & 0,0031 & 0,831 \\
\hline
\end{tabular}

Continuação tabela X.10: razões ${ }^{207} \mathrm{~Pb} /{ }^{235} \mathrm{U},{ }^{206} \mathrm{~Pb} /{ }^{238} \mathrm{U},{ }^{207} \mathrm{~Pb}^{206} \mathrm{~Pb}$, seus respectivos erros $(1 \sigma)$ e os valores de rho da amostra C-431 da unidade UBX.

\begin{tabular}{cccccccc} 
Ponto & ${ }^{207} \mathbf{P b} /{ }^{235} \mathbf{U}$ & 2s error & $\begin{array}{c}{ }^{206} \mathbf{P b} / \mathbf{2 3 8} \\
\mathbf{U}\end{array}$ & 2s error & $\begin{array}{c}\mathbf{2 0 7}_{\mathbf{P b}} \mathbf{2 0 6} \mathbf{P} \\
\mathbf{b}\end{array}$ & 2s error & rho \\
\hline $\mathbf{8 2 . 1}$ & 2,69858 & 0,12322 & 0,13814 & 0,00556 & 0,1466 & 0,0032 & 0,854 \\
$\mathbf{8 3 . 1}$ & 5,83587 & 0,26823 & 0,33198 & 0,01334 & 0,1284 & 0,0029 & 0,847 \\
$\mathbf{8 4 . 4}$ & 5,71600 & 0,26154 & 0,25521 & 0,01012 & 0,1697 & 0,0039 & 0,839 \\
$\mathbf{8 5 . 1}$ & 9,69102 & 0,43854 & 0,30500 & 0,01196 & 0,2334 & 0,0053 & 0,838 \\
$\mathbf{8 6 . 1}$ & 3,24671 & 0,18146 & 0,20316 & 0,01016 & 0,1132 & 0,0028 & 0,877 \\
$\mathbf{8 7 . 1}$ & 5,31771 & 0,23783 & 0,29642 & 0,01165 & 0,1311 & 0,0028 & 0,850 \\
\hline
\end{tabular}

Continuação tabela X.10: razões ${ }^{207} \mathrm{~Pb} /{ }^{235} \mathrm{U},{ }^{206} \mathrm{~Pb} /{ }^{238} \mathrm{U},{ }^{207} \mathrm{~Pb}{ }^{1206} \mathrm{~Pb}$, seus respectivos erros $(1 \sigma)$ e os valores de rho da amostra C-431 da unidade UBX.

Ponto error (Ma) $\quad{ }^{207} \mathrm{~Pb} /{ }^{235} \mathrm{U}$ Idade (Ma) $\quad$ error (Ma) $\begin{gathered}{ }^{207} \mathrm{~Pb} /{ }^{206} \mathrm{~Pb} \\ \text { Idade (Ma) }\end{gathered} \quad$ error (Ma) $\%$ Disc

\begin{tabular}{|ccccccc}
\hline $\mathbf{1 . 1}$ & 68,70 & 1823,61 & 36,59 & 2173,53 & 47,6 & 18,5 \\
\hline $\mathbf{2 . 1}$ & 70,00 & 1936,30 & 43,26 & 1799,76 & 25,6 & $-3,5$ \\
\hline $\mathbf{3 . 1}$ & 59,69 & 1820,76 & 37,27 & 2160,19 & 26,8 & 31,3 \\
\hline $\mathbf{4 . 1}$ & 51,30 & 1296,77 & 31,95 & 1236,05 & 29,1 & $-8,1$ \\
\hline $\mathbf{5 . 1}$ & 60,21 & 1922,46 & 38,58 & 2358,34 & 28,1 & 38,1 \\
\hline $\mathbf{6 . 1}$ & 72,94 & 1824,91 & 40,47 & 1817,44 & 32,3 & 0,4 \\
\hline $\mathbf{7 . 1}$ & 59,03 & 919,74 & 61,74 & 1702,78 & 82,8 & 64,8 \\
\hline $\mathbf{8 . 1 B}$ & 61,63 & 1582,79 & 36,34 & 1575,78 & 36,2 & $-3,6$ \\
\hline $\mathbf{8 . 2 B}$ & 58,88 & 1522,44 & 34,48 & 1528,72 & 28,6 & $-1,4$ \\
\hline $\mathbf{8 . 3 N}$ & 60,57 & 1558,83 & 34,77 & 1474,07 & 30,2 & $-10,7$ \\
\hline $\mathbf{9 . 1}$ & 38,64 & 987,91 & 31,91 & 980,61 & 55,3 & 5,4 \\
\hline $\mathbf{1 0 . 1}$ & 105,29 & 2258,52 & 58,50 & 2474,95 & 44,6 & 22,4 \\
\hline $\mathbf{1 1 . 1}$ & 65,22 & 1357,73 & 47,82 & 1601,62 & 58,8 & 24,9 \\
\hline
\end{tabular}




\begin{tabular}{lllllll}
\hline $\mathbf{1 2 . 1}$ & 35,85 & 1178,60 & 25,70 & 1173,72 & 39,8 & $-1,9$ \\
$\mathbf{1 3 . 1}$ & 48,98 & 1426,14 & 33,84 & 1453,63 & 48,5 & 1,8 \\
\hline $\mathbf{1 4 . 1}$ & 55,44 & 2041,14 & 28,78 & 2047,20 & 24,0 & 0,7 \\
$\mathbf{1 5 . 1}$ & 38,34 & 1323,41 & 26,11 & 1380,15 & 35,5 & 4,7 \\
$\mathbf{1 6 . 1}$ & 32,66 & 1465,09 & 28,33 & 2271,36 & 27,7 & 59,6 \\
$\mathbf{1 7 . 1}$ & 57,04 & 2006,55 & 29,95 & 1997,80 & 25,4 & $-0,5$ \\
\hline $\mathbf{1 8 . 1}$ & 58,01 & 2134,47 & 29,00 & 2118,68 & 23,1 & $-1,8$ \\
$\mathbf{1 9 . 1}$ & 49,39 & 1779,59 & 30,21 & 2029,88 & 25,8 & 23,8 \\
\hline $\mathbf{2 0 . 1}$ & 45,24 & 1122,82 & 31,74 & 1134,40 & 37,7 & 2,7 \\
$\mathbf{2 1 . 1}$ & 35,00 & 1118,58 & 26,87 & 1171,78 & 45,3 & 6,0 \\
\hline $\mathbf{2 2 . 1}$ & 44,06 & 1542,46 & 26,55 & 1545,13 & 27,0 & 0,5 \\
\hline $\mathbf{2 3 . 1}$ & 54,69 & 2004,80 & 28,69 & 2021,96 & 23,6 & 1,9 \\
\hline $\mathbf{2 4 . 1}$ & 35,81 & 1242,94 & 24,41 & 1285,60 & 31,0 & 5,1 \\
$\mathbf{2 5 . 1}$ & 59,54 & 2133,16 & 32,11 & 2142,37 & 33,2 & 0,2 \\
\hline $\mathbf{2 6 . 1}$ & 59,70 & 2150,26 & 30,93 & 2103,63 & 29,7 & $-4,4$ \\
$\mathbf{2 7 . 1}$ & 40,79 & 1451,08 & 25,92 & 1449,42 & 29,8 & 1,0 \\
\hline
\end{tabular}

Tabela X.11: idades ${ }^{207} \mathrm{~Pb} /{ }^{235} \mathrm{U},{ }^{206} \mathrm{~Pb} /{ }^{238} \mathrm{U},{ }^{207} \mathrm{~Pb}^{1206} \mathrm{~Pb}$, seus respectivos erros e os valores de concordância da amostra C-431 da unidade UBX.

\begin{tabular}{|c|c|c|c|c|c|c|c|}
\hline & $\begin{array}{c}{ }^{206} \mathrm{~Pb} /{ }^{238} \mathrm{U} \\
\text { Idade } \\
\text { (Ma) }\end{array}$ & error (Ma) & ${ }^{207} \mathrm{~Pb} /{ }^{235} \mathrm{U}$ Idade (Ma) & error (Ma) & $\begin{array}{l}{ }^{207} \mathrm{~Pb} /{ }^{206} \mathrm{~Pb} \\
\text { Idade (Ma) }\end{array}$ & error (Ma) & \% Disc \\
\hline 28.1 & 1468,10 & 41,45 & 1456,21 & 25,81 & 1428,96 & 29,5 & $-3,1$ \\
\hline 29.1 & 1647,65 & 46,36 & 1790,24 & 28,81 & 1989,07 & 29,9 & 19,4 \\
\hline 30.1 & 852,14 & 29,29 & 1077,52 & 26,44 & 1685,18 & 35,7 & 52,7 \\
\hline 31.1 & 1782,35 & 50,23 & 1781,96 & 28,74 & 1771,82 & 29,2 & $-0,7$ \\
\hline 32.1 & 988,64 & 29,95 & 955,50 & 23,92 & 881,69 & 49 & $-13,1$ \\
\hline 33.1 & 2083,47 & 58,63 & 2033,33 & 30,41 & 2015,86 & 27,5 & $-3,9$ \\
\hline 34.1 & 2100,01 & 59,84 & 2196,26 & 35,01 & 2331,52 & 40,0 & 11,6 \\
\hline 35.1 & 2459,45 & 80,39 & 2477,95 & 40,16 & 2454,74 & 37,4 & $-0,2$ \\
\hline 36.1 & 1360,93 & 46,88 & 1355,11 & 31,32 & 1353,52 & 40,3 & $-0,6$ \\
\hline 37.1 & 1274,29 & 37,35 & 1270,89 & 25,86 & 1219,90 & 37,1 & $-4,9$ \\
\hline 38.1 & 1597,13 & 49,28 & 1966,33 & 33,39 & 2396,48 & 34,1 & 37,6 \\
\hline 39.1 & 2721,07 & 86,91 & 2723,63 & 40,79 & 2751,42 & 36,1 & 1,4 \\
\hline 40.1 & 1384,93 & 46,30 & 1359,21 & 30,71 & 1352,88 & 40,5 & $-2,6$ \\
\hline 41.1 & 1410,47 & 43,84 & 1405,33 & 29,34 & 1388,12 & 39,6 & $-1,8$ \\
\hline 42.1 & 1381,77 & 43,89 & 1363,85 & 29,26 & 1335,54 & 39,2 & $-3,8$ \\
\hline 43.1 & 1041,46 & 34,09 & 1035,39 & 26,24 & 1019,63 & 45,9 & $-2,3$ \\
\hline 44.1 & 744,13 & 26,09 & 747,34 & 27,15 & 797,71 & 79 & 7,1 \\
\hline 45.1 & 1513,34 & 53,93 & 1501,64 & 34,24 & 1501,11 & 40,6 & $-0,9$ \\
\hline 46.1 & 564,94 & 23,14 & 671,73 & 23,49 & 1048,15 & 49,5 & 48,1 \\
\hline 47.1 & 1297,95 & 54,31 & 1289,98 & 37,01 & 1325,70 & 47,9 & 2,3 \\
\hline 48.1 & 1317,44 & 47,97 & 1339,76 & 34,60 & 1325,41 & 51,4 & 0,7 \\
\hline 49.1 & 1217,66 & 47,00 & 1238,05 & 33,57 & 1274,94 & 46,5 & 4,9 \\
\hline 50.1 & 1178,28 & 47,49 & 1183,15 & 35,92 & 1254,90 & 58,0 & 6,7 \\
\hline 51.1 & 2272,07 & 74,92 & 2225,53 & 39,31 & 2216,28 & 39,7 & $-3,0$ \\
\hline 52.1 & 2344,21 & 72,06 & 2488,69 & 38,14 & 2625,97 & 37,0 & 12,8 \\
\hline
\end{tabular}




\begin{tabular}{|c|c|c|c|c|c|c|c|}
\hline 53.1 & 1270,32 & 42,22 & 1369,59 & 31,12 & 1557,03 & 42,7 & 20,3 \\
\hline 54.1 & 927,37 & 30,88 & 1097,81 & 28,41 & 1483,18 & 48,7 & 40,2 \\
\hline 55.1 & 779,04 & 26,74 & 989,85 & 26,41 & 1495,25 & 44,6 & 50,8 \\
\hline 56.1 & 1577,43 & 49,19 & 1554,67 & 33,32 & 1533,69 & 48,6 & $-3,2$ \\
\hline 57.1 & 771,03 & 33,50 & 955,74 & 32,03 & 1361,06 & 51,9 & 46,0 \\
\hline 58.1 & 1122,83 & 37,42 & 1150,13 & 28,96 & 1224,27 & 48,0 & 9,0 \\
\hline 59.1 & 1001,09 & 33,99 & 1046,35 & 28,90 & 1094,43 & 55,3 & 9,2 \\
\hline 60.1 & 827,29 & 29,48 & 915,33 & 25,97 & 1072,85 & 47,3 & 24,4 \\
\hline 61.1 & 1115,55 & 37,06 & 1376,37 & 31,12 & 1833,50 & 42,2 & 42,6 \\
\hline 62.1 & 1983,45 & 67,46 & 2057,06 & 38,45 & 2163,49 & 38,9 & 9,7 \\
\hline 63.1 & 683,92 & 31,76 & 922,71 & 32,80 & 1627,09 & 49,8 & 61,0 \\
\hline 64.1 & 1896,85 & 83,89 & 1900,64 & 43,75 & 1912,60 & 23,2 & 1,0 \\
\hline 65.1 & 1982,93 & 87,88 & 1956,23 & 44,45 & 1944,66 & 22,4 & $-2,3$ \\
\hline 66.1 & 2012,49 & 94,73 & 2093,28 & 48,61 & 2179,50 & 25,2 & 8,9 \\
\hline 67.1 & 2096,52 & 90,63 & 2106,71 & 44,76 & 2143,01 & 21,8 & 2,5 \\
\hline 68.1 & 2025,91 & 88,48 & 2072,20 & 44,82 & 2142,38 & 22,4 & 6,3 \\
\hline 69.1 & 831,40 & 43,57 & 1567,56 & 47,12 & 2763,94 & 40,5 & 74,3 \\
\hline 70.1 & 963,86 & 46,61 & 1286,91 & 38,22 & 1891,80 & 26,7 & 52,7 \\
\hline
\end{tabular}

Tabela X.11: idades ${ }^{207} \mathrm{~Pb} /{ }^{235} \mathrm{U},{ }^{206} \mathrm{~Pb} /{ }^{238} \mathrm{U},{ }^{207} \mathrm{~Pb}{ }^{1206} \mathrm{~Pb}$, seus respectivos erros e os valores de concordância da amostra C-431 da unidade UBX.

\begin{tabular}{|c|c|c|c|c|c|c|c|}
\hline & $\begin{array}{c}{ }^{206} \mathrm{~Pb} /{ }^{238} \mathrm{U} \\
\text { Idade } \\
\text { (Ma) }\end{array}$ & error (Ma) & ${ }^{207} \mathrm{~Pb} /{ }^{235} \mathrm{U}$ Idade (Ma) & error (Ma) & $\begin{array}{l}{ }^{207} \mathrm{~Pb} /{ }^{206} \mathrm{~Pb} \\
\text { Idade (Ma) }\end{array}$ & error (Ma) & \% Disc \\
\hline 71.1 & 1889,33 & 88,29 & 2276,07 & 49,54 & 2656,72 & 27,9 & 33,2 \\
\hline 72.1 & 1299,68 & 59,70 & 1480,17 & 39,63 & 1772,39 & 25,5 & 29,4 \\
\hline 73.1 & 1978,14 & 99,59 & 1976,58 & 51,46 & 1998,46 & 31,1 & 1,2 \\
\hline 74.1 & 1620,59 & 73,65 & 1675,75 & 44,52 & 1766,27 & 41,0 & 9,3 \\
\hline 75.1 & 1497,98 & 69,01 & 1710,96 & 42,63 & 2037,07 & 23,5 & 29,6 \\
\hline 76.1 & 1026,41 & 47,34 & 1077,02 & 33,07 & 1212,68 & 24,6 & 16,6 \\
\hline 75.1 & 2439,17 & 98,65 & 2527,03 & 51,51 & 2631,45 & 50,5 & 8,8 \\
\hline 76.1 & 1211,20 & 54,04 & 1453,49 & 46,62 & 1850,67 & 69,9 & 37,8 \\
\hline 77.1 & 841,84 & 36,05 & 1020,83 & 33,64 & 1544,91 & 53,9 & 48,5 \\
\hline 78.1 & 1553,15 & 52,35 & 1556,82 & 35,64 & 1518,34 & 50,8 & $-2,6$ \\
\hline 79.1 & 1560,69 & 52,85 & 1560,07 & 35,99 & 1531,52 & 51,5 & $-2,1$ \\
\hline 80.1 & 840,82 & 42,92 & 1193,87 & 42,55 & 1910,92 & 55,2 & 59,6 \\
\hline 81.1 & 993,92 & 35,02 & 1422,79 & 33,33 & 2193,18 & 42,8 & 58,9 \\
\hline 82.1 & 834,15 & 31,40 & 1328,07 & 33,28 & 2306,97 & 40,9 & 67,9 \\
\hline 83.1 & 1847,98 & 64,22 & 1951,75 & 39,08 & 2076,16 & 43,1 & 12,6 \\
\hline 84.4 & 1465,29 & 51,76 & 1933,79 & 38,79 & 2554,32 & 41,7 & 47,5 \\
\hline 85.1 & 1716,05 & 58,81 & 2405,85 & 40,82 & 3075,46 & 39,4 & 50,1 \\
\hline 86.1 & 1192,27 & 54,23 & 1468,39 & 42,49 & 1850,63 & 48,5 & 38,9 \\
\hline 87.1 & 1673,53 & 57,65 & 1871,71 & 37,52 & 2112,57 & 41,4 & 23,6 \\
\hline
\end{tabular}

Tabela X.11: idades ${ }^{207} \mathrm{~Pb} /{ }^{235} \mathrm{U},{ }^{206} \mathrm{~Pb} /{ }^{238} \mathrm{U},{ }^{207} \mathrm{~Pb}{ }^{1206} \mathrm{~Pb}$, seus respectivos erros e os valores de concordância da amostra C-431 da unidade UBX. 


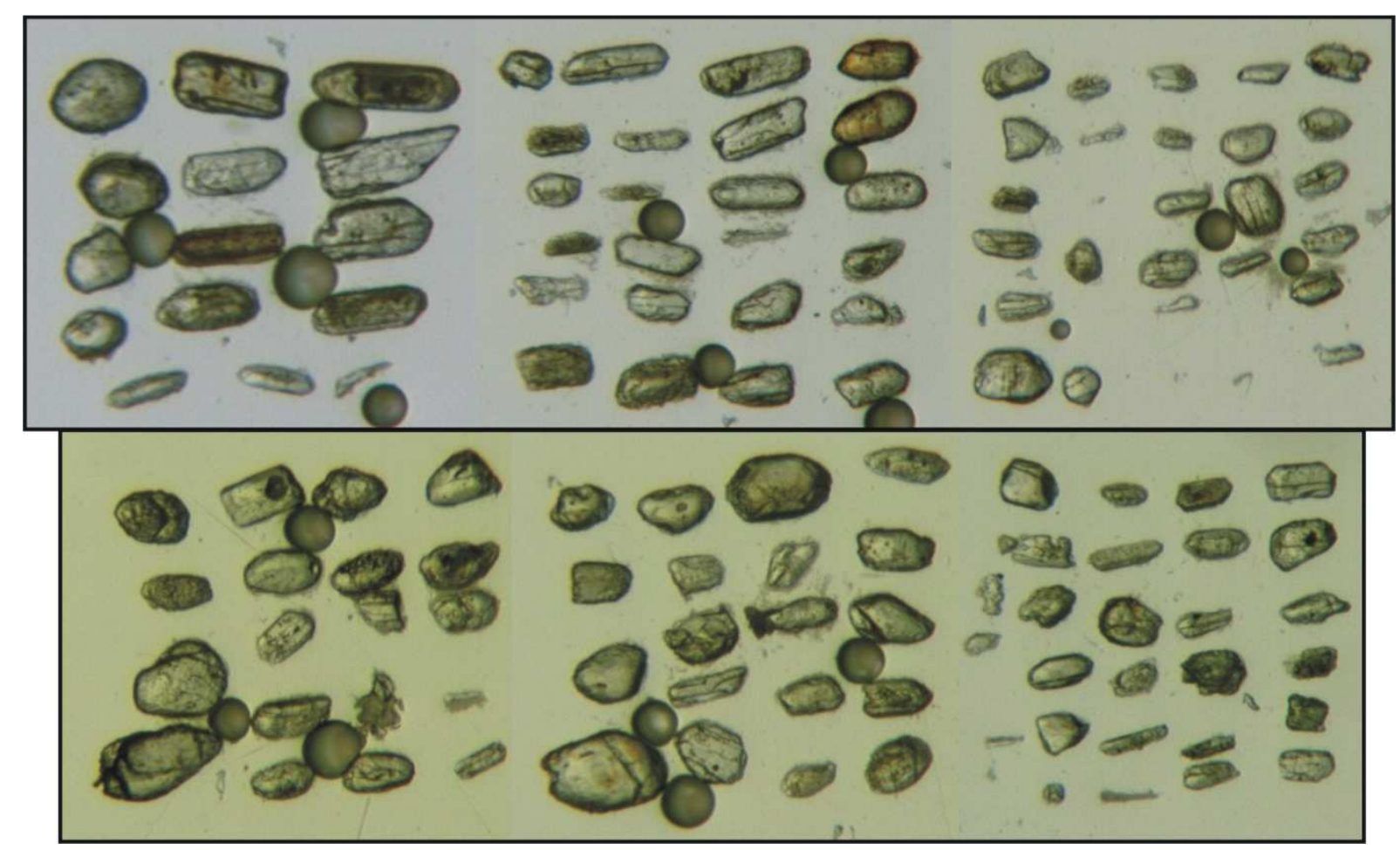

Figura X.11: cristais de zircão detrítico da amostra CAR-II-179 separados para análise do sistema U-Pb.

As duas idades neoproterozóicas foram obtidas na borda de dois cristais bipiramidados, ambos com delgada auréola de sobrecrescimento, de larguras inferiores ao spot laser. As idades $1019 \pm 46$ Ma e $798 \pm 79$ Ma foram obtidas na mesma posição em um mesmo cristal zonado (figura X.12), aquela no limite Neoproterozóico-Mesoproterozóico é a que apresenta melhor concordância e menor erro associado (tabela X.12). Os cristais de idade arqueana são variados, sendo o mais antigo arredondado e sem zoneamento de crescimento aparente. Apresentam delgada borda de sobrecrescimento texturalmente amorfa.

As idades $\mathrm{T}_{\mathrm{DM}}$ entre 2,46 e 2,05 Ga obtidas para o grafita-muscovita xisto devem, assim, representar uma mistura de sedimentos de proveniência diversa, do Arqueano ao Neoproterozóico, com predomínio de uma área fonte Mesoproterozóica.

A idade máxima para a sedimentação da Formação Campestre foi de 790 Ma.

\section{X.5. Prováveis áreas-fonte}

Idades paleoproterozóicas e arqueanas como as obtidas para o quartzito da Formação Campestre são facilmente encontradas no Cráton São Francisco (figura X.14) que apresenta granitóides de idades paleoproterozóicas Sideriano-Riacianas, entre 2,5 e 2,1 Ga e rochas 
ígneas vulcânicas Estaterianas, entre 1760 e 1710 pertencentes ao Supergrupo Espinhaço (Machado et al., 1989; Schobbenhaus et al., 1994; Dussin e Dussin, 1995). Rochas de idade arqueana ao redor de 2,7 Ga (Noce et al., 1998; Teixeira et al., 2000 Ávila et al., 2005). Entretanto, $50 \%$ dos pontos analisados neste trabalho apresentaram idade mesoproterozóica concentrada entre 1,45 e 1,15 Ga e cristais de idade neoproterozóica de 882 e 798 Ma.

A alta concentração de zircões mesoproterozóicos no quartzito analisado, semelhantes as obtidas por Pimentel et al. (2011) e Valeriano et al. (2004) na Faixa Brasilia, torna a proveniência a partir de diques máficos do Craton São Francisco sugerida por Valladares et al. (2004) improvável e sugere que faixas orogências mesoproterozóicas deveriam estar expostas e próximas e da bacia de sedimentação. 


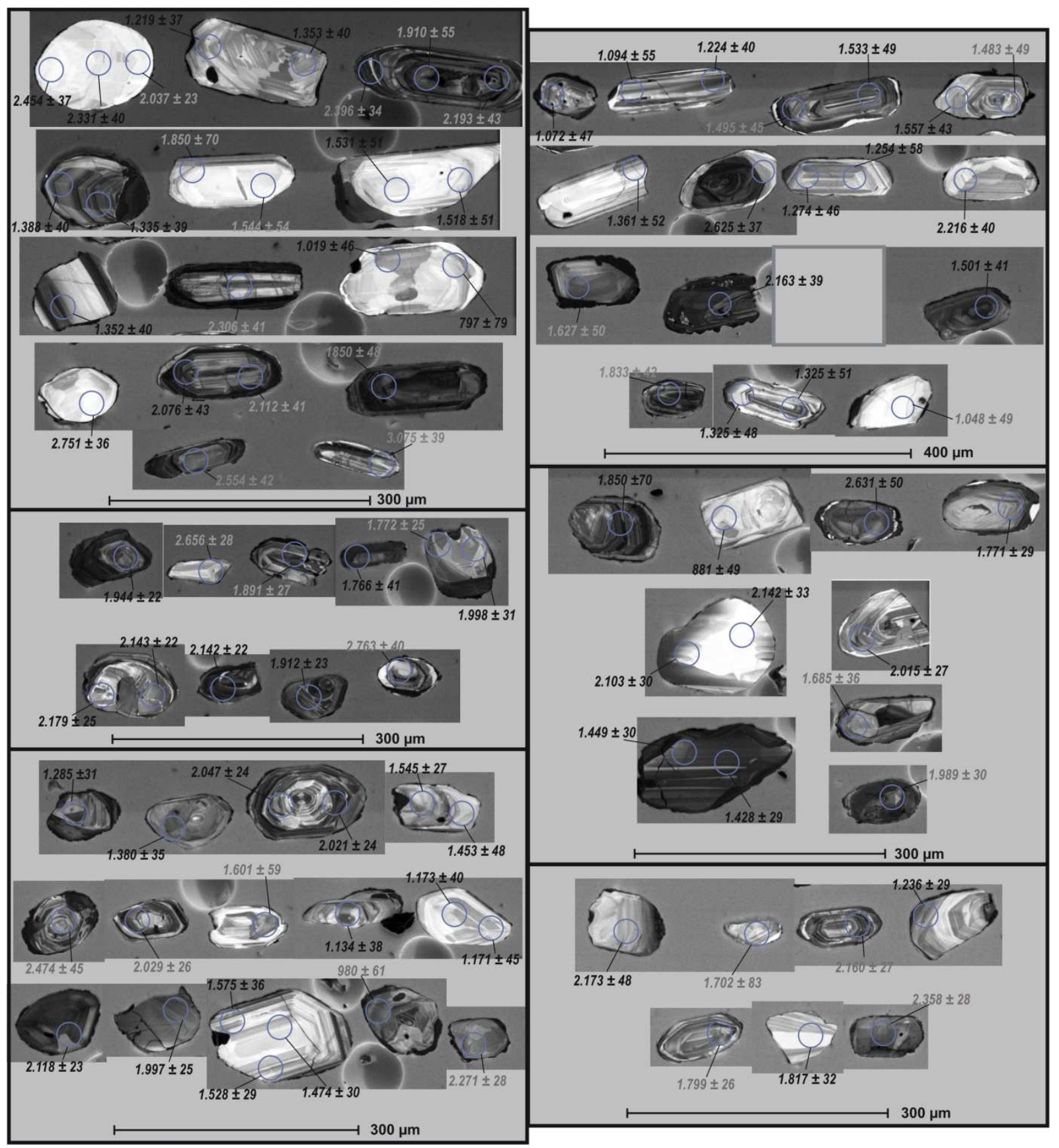

Figura X.12: imagens back-scattered dos cristais detríticos da amostra CAR-II-179 analisados. Idades em milhões de anos (Ma). Círculos azuis acompanhados por idades na cor preta correspondem à análises com concordância acima de $80 \%$; Círculos azuis acompanhados por idades na cor cinza correspondem à análises descartadas com concordância abaixo de $80 \%$. 


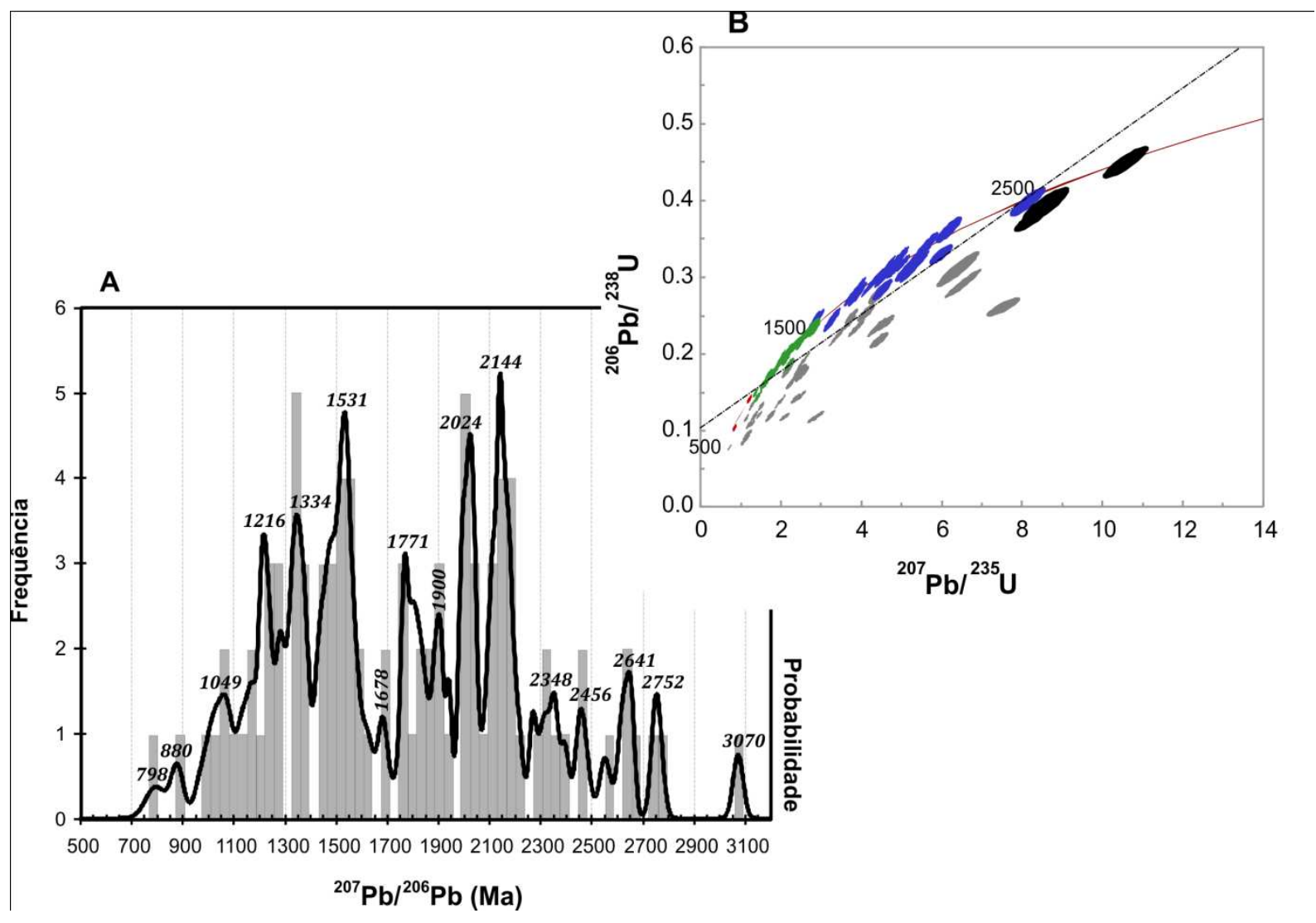

Figura X.13: diagrama concórdia ${ }^{207} \mathrm{~Pb} /{ }^{238} \mathrm{U} v s .{ }^{206} \mathrm{~Pb} /{ }^{238} \mathrm{U}(\mathbf{B})$ e distribuição de probabilidade do quartzito da Formação Campestre (A). No diagrama concórdia, as elipses vermelhas referem-se à idades no Neoproterozóico; elipses verdes referem-se às idades no Mesoproterozóico; elipses azuis referem-se às idades no Paloproterozóico; elipses pretos referem-se às idades no Arqueano; elipses na cor cinza referem-se às idades ${ }^{207} \mathrm{~Pb} /{ }^{206} \mathrm{~Pb} \mathrm{com}$ concordância abaixo de $80 \%$.

Na Faixa Apiaí (figura X.14) encontram-se rochas metavulcânicas e metabásicas com idades entre 1036 e 1500 Ma (Basei et al., 2003 e 2008; Siga Jr. et al., 2011) relacionadas à cobertura metassedimentar. Subordinadamente ocorrem, nos núcleos de embasamento das faixas mesoproterozóicas, gnaisses monzo e sienograníticos do Estateriano (Kaulfuss, 2001, Prazeres Filho, 2005; Siga Jr. et al., 2005 e 2011). O baixo conteúdo em zircão das rochas metabásicas desta faixa orogênica não as indicariam como fonte para os sedimentos estudados. 


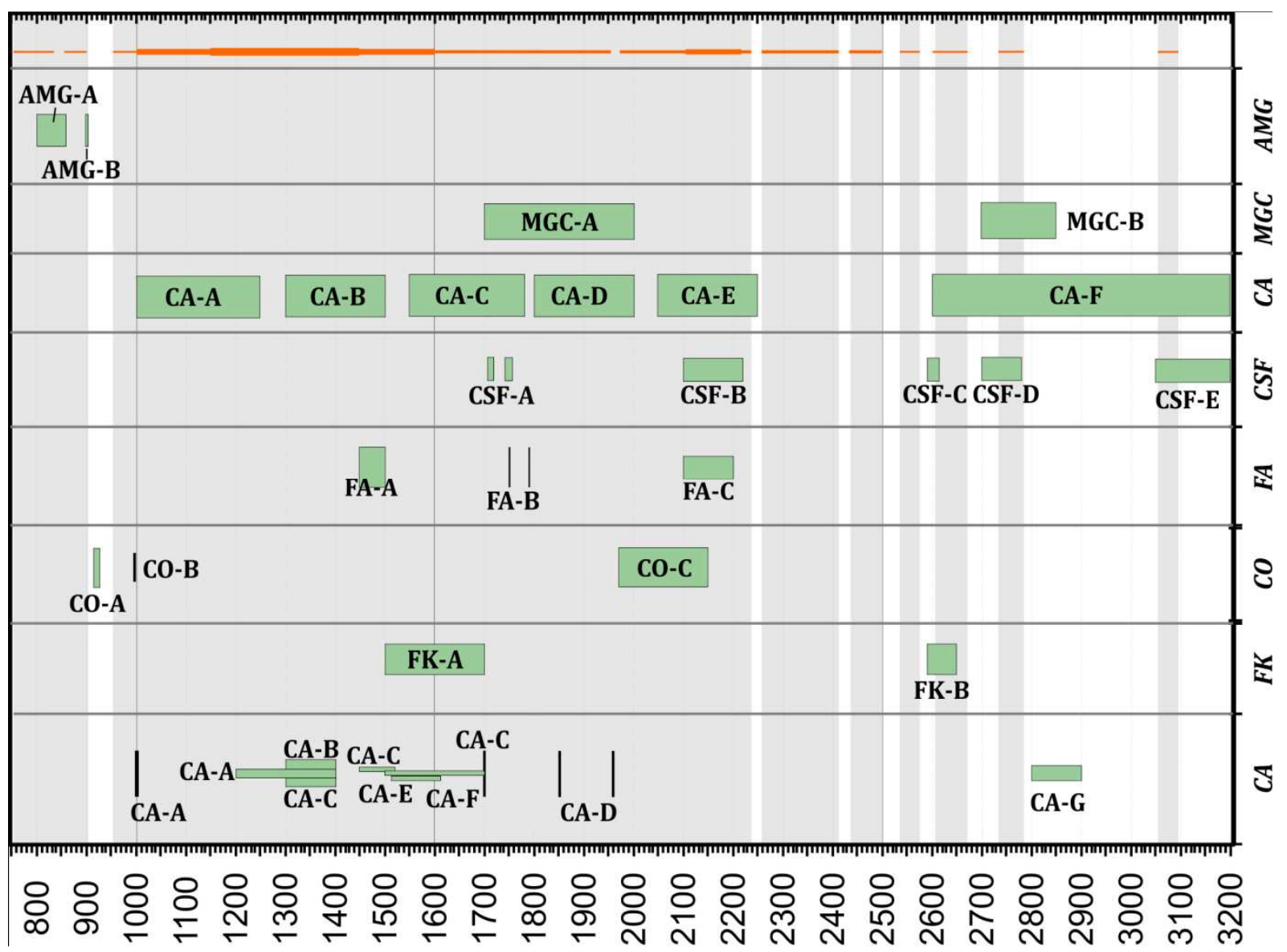

Figura X.14: Idades obtidas nos cristais de zircão detrítico da amostra CAR-II-179 (linhas laranja e intervalos em cinza) e as idades das possíveis rochas-fonte para os sedimentos da Formação Campestre (em verde). (AMG) ARCO MAgMÁticos GOIÁS: AMG-A - tonalitos e granodioritos (Mara Rosa) e AMG-B - rochas metavulcanossedimentares; (MGC) MACIÇO GOIÁS CENTRAL: MGC-A - Complexos Paleoproterozóicos e MGC-B - Núcleos Arqueanos; (CA) CRÁTON AMAZÔNICO: CA-A - Sunsás-Aguapeí, CA-B Rondonian-San Ignácio, CA-C - Rio Negro-Juruena, CA-D - Ventuari-Tapajós, CA-E - Maroni-Itacaiúnas e CA-F - Bloco Xingu-Iricoumé; (CSF) CRÁTON SÃO FRANCISCO: CSF-A - vulcânicas do Supergrupo Espinhaço, CSF-B - Cinturão Mineiro, CSF-C - Granitóides, CSF-D - Terrenos TTG e Greenstone Belt e CSFE - Ortognaisses migmatíticos do Complexo Campo Belo; (FA) FAIXA APIAÍ: FA-A - Metabásicas da Formação Betara, FA-B - Metabásicas e sienogranitos Núcleo Betara; FA-C - Granodioritos protomiloníticos; (CO) CONGO OESTE: CO-A - basaltos, CO-B - riolitos e granitos peralcalinos e CO-C - embasamento; (FK) FAIXA KAOKO: FK-A - granitóides e FK-B - embasamento; (CA) CRÁTON ANGOLA: CA-A Granitóides alcalinos e cálcio-alcalinos, CA-B - Associação granito-pórfiro-riolito, CA-C - Magmatismo anorogênico, CA-D - Granitos e sienitos, CA-E - Granitos e tonalitos, CA-F - Granitos e migmatitos e CA-G Complexo gabro-norito-charnokito. Referências: AMG: Cordani e Teixeira (2011) e Pimentel et al. (2011); MGC: Campos Neto (2000) e Cordani e Teixeira (2007), Pimentel et al. (2011); CA: Cordani e Teixeira (2007); CSF: Machado et al. (1989), Schobbenhaus et al. (1994), Dussin e Dussin (1995), Noce et al. (1998), Teixeira et al. (2000) e Ávila et al. (2005 e 2010); FA: Kaulfuss (2001), Basei et al (2003 e 2008), Prazeres Filho (2005), Siga Jr. et al. (2005 e 2011); CO: Basei et al. (2008); FK: Basei et al. (2008); CA: Heilbron et al. (2008).

Basei et al. (2008) sugere que a fonte para os sedimentos do segmento central da Faixa Ribeira poderia estar localizada na África devido à similaridade das idades encontradas em zircões detríticos das unidades destas faixas com as faixas Gariep, Damara e West Congo 
(figura X.14). Entretanto, nestas faixas não são encontradas idades Arqueanas, justificadas pela barreira causada por um alto estrutural do Complexo Namaqua, de idade fimmesoproterozóica, no Esteniano (Frimmel et al., 2002; Basei et al., 2008)

O cráton Amazônico (figura X.14) é formado por faixas orogênicas de idade mesoproterozóica representado pelos cinturões acrescionários Sunsas-Aguapeí (1250 a 1000 Ma), Rondoniano-San Ignácio (1500 a 1300 Ma) e Rio Negro-Juruena (1780 a 1550) (Cordani e Teixeira, 2007). Idades no Paleoproterozóico entre 2250 e 1800 (cinturão Ventuari-Tapajós e província tectônica Maroni-Itacaiunas) são encontradas, além de núcleo Arqueanos entre 3200 e 2600 Ma (Cordani e Teixeira, 2007).

No Maciço Central de Goiás, séries arqueanas (2850 e $2700 \mathrm{Ma}$ ) ocorrem como substrato do arco magmático, em parte insular, Mara Rosa, de idade entre 860 e 800 Ma e, mais a sul, no noroeste do Arco Magmático de Goiás, de até 900 Ma (Pimental et al., 2011).

Os zircões detríticos do Estateriano, do Riaciano, Neoarqueano e do Mesoarqueano podem ser encontrados no sul do Cráton do São Francisco, respectivamente, no vulcanismo e plutonismo relacionado ao Rift Espinhaço, no Cinturão Mineiro, no Super Grupo Rio das Velhas e domos granitóides associados e nos Migmatitos Campo Belo.

No entanto as idades no Mesoproterozóico, compatíveis com a super faixa orogênica grenviliana, estão ausentes neste cráton. Podem estar parcialmente representadas nas faixas marginais do Cráton de Angola (Heilbron et al., 2008) e sobretudo nas faixas orogênicas sequenciadas do Cráton Amazônico (figura X.14).

As idades de zircão detrítico no Toniano podem ser oriundas parte do arco insular Mara Rosa e parte do Arco Magmático de Goiás, na borda da Microplaca Paranapanema.

Se diferentes massas cratônicas (placas, ou microplacas) possam ter sido área fonte para os depósitos psamíticos da Formação Campestre, a paleogeografia mais provável, provavelmente para todo o Grupo Carrancas, é a de um ambiente de rifte, antecessor à deriva e ao estabelecimento de uma margem continental passiva.

A abrangência das idades dos grãos detríticos de zircão da Formação Campestre (tanto no Arqueano e Paleoproterozóico, quanto no Mesoproterozóico), como para as formações Chapada dos Pilões e Paracatu (Pimentel et al., 2011) permite a correlação, no Orógeno Brasília, entre os Grupos Carrancas e Canastra. 


\section{CAPÍTUlo XI}

\section{COMPARAÇõES ENTRE AS UNIDADES BIOTITA XISTO E XISTo SANTo ANTôNIO}

Os dados de geoquímica de elementos maiores, menores e traços para as rochas do Xisto Santo Antônio (XSA) da Nappe Andrelândia foram extraídos de Campos Neto et al. (2007 e 2011).

Descrito pela primeira vez por Ribeiro e Heilbron (1982) como granada-cianita-biotita xisto do Grupo Andrelândia, passou a ser denominado biotita xisto Santo Antônio por Trouw et al. (1983). Compõe, juntamente com o Xisto Serra da Boa Vista e o Xisto Rio Capivari, a Nappe Andrelândia, com espessura aparente de cerca de 850 m, base do Sistema de Nappes Andrelândia (Campos Neto et al., 2007). Assim como a Unidade Biotita Xisto, aflora na forma de extensos lajedos e tem como característica diagnóstica lentes de quartzo na forma de dobras e sigmóides que acompanham a foliação principal. As rochas do Xisto Santo Antônio são dominantemente granoblásticas e diferem-se daquelas da Unidade Biotita Xisto pelo alto teor modal em plagioclásio e menor conteúdo de muscovita em sua composição. São rutilogranada-biotita-plagioclásio-quartzo xistos, localmente com estaurolita e cianita (sillimanita) e encontram-se sob condições metamórficas de fácies anfibolito.

\section{XI.1. Elementos maiores e menores}

As concentrações de elementos maiores e menores (tabela XI.1) foram plotadas em diagramas Harker (figura XI.1). Demonstram que a correlação negativa entre $\mathrm{SiO}_{2}$ vs. $\mathrm{Al}_{2} \mathrm{O}_{3}$, $\mathrm{Fe}_{2} \mathrm{O}_{3}, \mathrm{MnO}, \mathrm{MgO}$ e $\mathrm{K}_{2} \mathrm{O}$ e positiva entre $\mathrm{SiO}_{2}$ vs. $\mathrm{P}_{2} \mathrm{O}_{5}, \mathrm{TiO}_{2}, \mathrm{CaO}$ e $\mathrm{Na}_{2} \mathrm{O}$, observadas na UBX, se mantém para as amostras do XSA. Neste diagramas, principalmente nos trends composicionais dos óxidos de alumínio, ferro ${ }^{3+}$ e magnésio, observa-se uma clara afinidade geoquímica entre as rochas da unidade UBX e do XSA.

As amostras do XSA possuem assinatura geoquímica semelhante àquelas da unidade UBX que foram proximais (capítulo VI - amostras CAR-I-51, C-341, C-337, C-333, C-325c e C-410). A maior concentração de $\mathrm{CaO}$ e menor de $\mathrm{K}_{2} \mathrm{O}$ são as exceções e provavelmente se devem à maior concentração de plagioclásio e menores teores de muscovita nas rochas do XSA. 

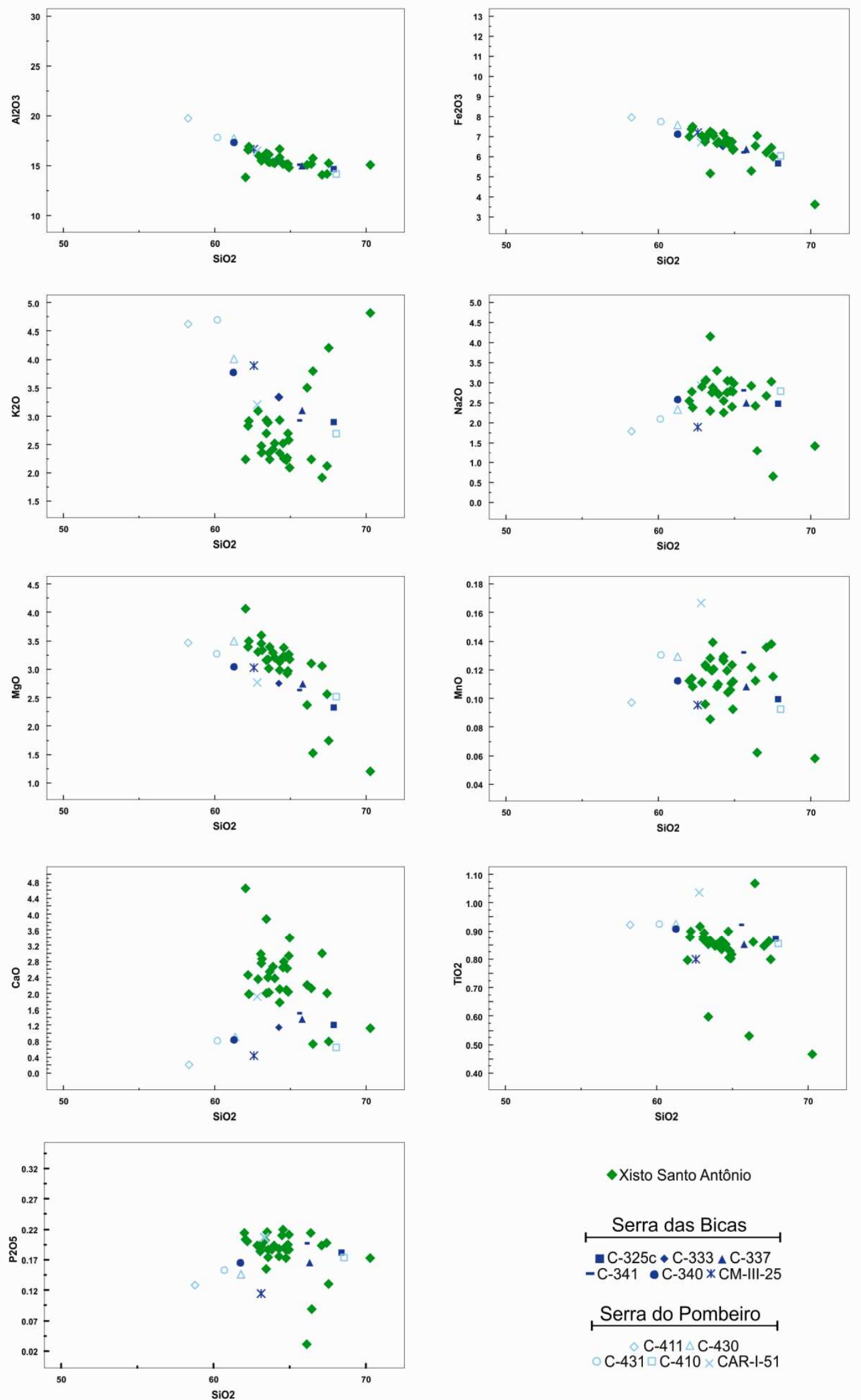

- Xisto Santo Antônio

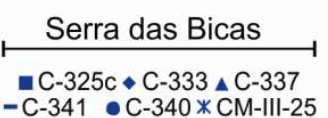

Serra do Pombeiro

C-431 C-411 $\triangle$ C $-430 \times$ CAR-I- 51

Figura XI.1: gráficos binários de dispersão de $\mathrm{SiO}_{2}$ vs. elementos maiores e menores analisados por FRX para as amostras do XSA e da unidade UBX. 


\begin{tabular}{|c|c|c|c|c|c|c|c|c|c|c|}
\hline & $\mathrm{SiO}_{2}$ & $\mathrm{TiO}_{2}$ & $\mathrm{Al}_{2} \mathrm{O}_{3}$ & $\mathrm{Fe}_{2} \mathrm{O}_{3}$ & MnO & Mg0 & $\mathrm{CaO}$ & $\mathrm{Na}_{2} \mathrm{O}$ & $\mathrm{K}_{2} \mathbf{O}$ & $\mathbf{P}_{2} \mathbf{O}_{5}$ \\
\hline UBX & $\begin{array}{c}58,25 \\
a \\
68,09\end{array}$ & $\begin{array}{c}0,80 \mathrm{a} \\
1,03\end{array}$ & $\begin{array}{c}14,14 \mathrm{a} \\
19,69\end{array}$ & $\begin{array}{c}5,65 \mathrm{a} \\
7,92\end{array}$ & $\begin{array}{c}0,09 \mathrm{a} \\
0,17\end{array}$ & $\begin{array}{c}2,32 \mathrm{a} \\
3,48\end{array}$ & $\begin{array}{c}0,80 \mathrm{a} \\
1,90\end{array}$ & $\begin{array}{c}1,79 \mathrm{a} \\
2,81\end{array}$ & $\begin{array}{c}2,69 a \\
4,69\end{array}$ & $\begin{array}{c}0,14 \mathrm{a} \\
0,22\end{array}$ \\
\hline XSA & $\begin{array}{c}62,05 \\
a \\
70,31\end{array}$ & $\begin{array}{r}0,467 \\
\text { a } 1,07\end{array}$ & $\begin{array}{c}13,83 \mathrm{a} \\
16,88\end{array}$ & $\begin{array}{c}3,60 \mathrm{a} \\
7,46\end{array}$ & $\begin{array}{c}0,058 \\
a \\
0,139\end{array}$ & $\begin{array}{c}1,20 \mathrm{a} \\
4,06\end{array}$ & $\begin{array}{c}0,71 \mathrm{a} \\
4,63\end{array}$ & $\begin{array}{c}0,65 \mathrm{a} \\
4,16\end{array}$ & $\begin{array}{c}1,92 \mathrm{a} \\
4,82\end{array}$ & $\begin{array}{l}0,03 \mathrm{a} \\
0,219\end{array}$ \\
\hline
\end{tabular}

Tabela XI.1: Síntese dos resultados obtidos para elementos maiores e menores por análises de FRX das amostras do XSA e da unidade UBX. Valores em \% peso de óxido.

Considerando que $\mathrm{Al}, \mathrm{Fe}, \mathrm{Mg}$ e $\mathrm{K}$ encontram-se com maior frequência em argilominerais, enquanto quartzo e feldspato se concentram em frações arenosas (Taylor e McLennan, 1985), as amostras do XSA são mais enriquecidas em sedimentos de granulação areia do que as amostras da unidade UBX.

\section{XI.1.1. Classificação}

Nos diagramas de classificação de arenitos, as amostras do XSA e da unidade UBX apresentam assinatura geoquímica semelhante, demonstrada anteriormente pelos trends dos diagramas Harker da figura XI.1. As amostras do XSA apresentam maiores valores para as razões $\mathrm{Na}_{2} \mathrm{O} / \mathrm{K}_{2} \mathrm{O}$ e $\mathrm{Fe}_{2} \mathrm{O}_{3} / \mathrm{K}_{2} \mathrm{O}$. Maiores proporções de fragmentos líticos vulcânicos aumentariam a proporção de plagioclásio e de minerais ferromagnesianos no sedimento, o que, por sua vez, ocasionaria o aumento de $\mathrm{Fe}^{3+}$ e a diminuição de $\mathrm{K}^{+}$, este proveniente de feldspato potássico detrítico. As diferentes concentrações $\mathrm{CaO}$ e $\mathrm{K}_{2} \mathrm{O}$ no XSA discutidas no item anterior corroboram esta hipótese.

Nos diagramas de classificação química de sedimentos (Pettijohn et al., 1972 - figura XI.2 e Herron, 1988 - figura XI.3) nota-se uma correlação entre as amostras XSA e UBX.

\section{XI.1.2. Chemical Index of Alteration - CIA}

As amostras do XSA apresentaram valores baixos para CIA (Nesbitt e Young, 1982), entre 47,85 e 68,28, sugerindo que as rochas analisadas sofreram, quando sedimentos, intemperismo químico leve em um curto período de tempo, ou, por outro lado, resultam de 
uma prevalência de intemperismo físico na área-fonte. Esses valores de CIA são menores do que os apresentados pela unidade UBX (tabela XI.2) sugerindo uma relação mais proximal da área-fonte para o Xisto Santo Antônio.

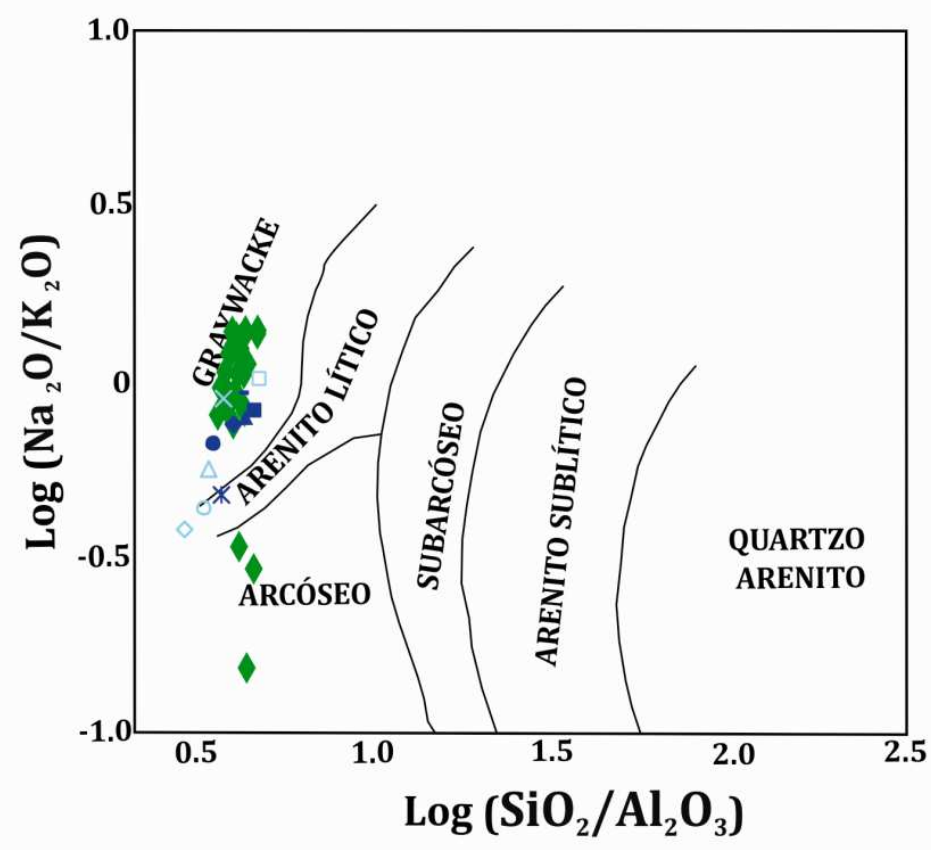

- Xisto Santo Antônio Serra das Bicas

- C-325c $\bullet \mathrm{C}-333 \wedge \mathrm{C}-337$ $-\mathrm{C}-341 \bullet \mathrm{C}-340 * \mathrm{CM}-\mathrm{III}-25$

Serra do Pombeiro $\mathrm{C}-411 \triangle \mathrm{C}-430$ C- $431 \square$ C- $-410 \times$ CAR-I-51

Figura XI.2: amostras do XSA e da unidade UBX plotadas no diagrama de classificação química de arenitos segundo Pettijohn et al. (1972).

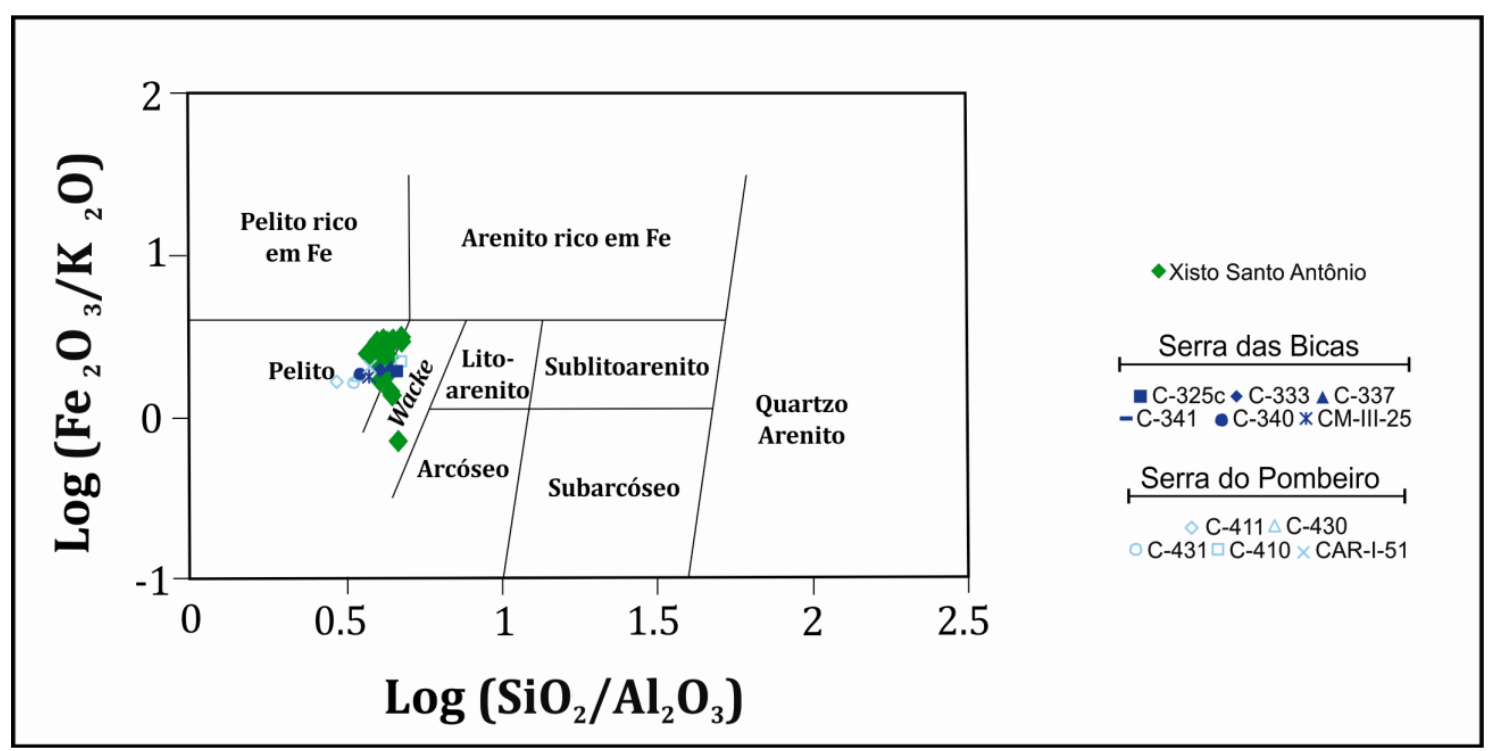

Figura XI.3: amostras do XSA da unidade UBX plotadas no diagrama de classificação química de arenitos segundo Herron (1988). 
As concentrações de elementos maiores obtidas também foram plotadas no gráfico ternário $\mathrm{A}\left(\mathrm{Al}_{2} \mathrm{O}_{3}\right)-\mathrm{CN}\left(\mathrm{CaO}+\mathrm{Na}_{2} \mathrm{O}\right)-\mathrm{K}\left(\mathrm{K}_{2} \mathrm{O}\right)$ de avaliação de intensidade de intemperismo (figura XI.4), sugerido por McLennan et al. (1990). As rochas do Xisto Santo Antônio seguem o mesmo padrão de intemperismo das rochas da unidade UBX, a partir de composições iniciais semelhantes à de andesitos de arcos de ilha. $\mathrm{O}$ caráter mais proximal dos sedimentos precursores XSA fica explicitado neste diagrama.

\section{CIA}

\begin{tabular}{cc}
\hline UBX & 58,41 a 70,26 \\
\hline XSA & 47,85 a 68,28 \\
\hline
\end{tabular}

Tabela XI.2: valores de CIA para as amostras do XSA e da unidade UBX. CIA $=\left[\mathrm{Al}_{2} \mathrm{O}_{3} /\left(\mathrm{Al}_{2} \mathrm{O}_{3}+\mathrm{CaO}+\mathrm{Na} \mathrm{O}_{2}\right.\right.$ $\left.\left.+\mathrm{K}_{2} \mathrm{O}\right)\right] * 100$; óxidos em proporção molecular.

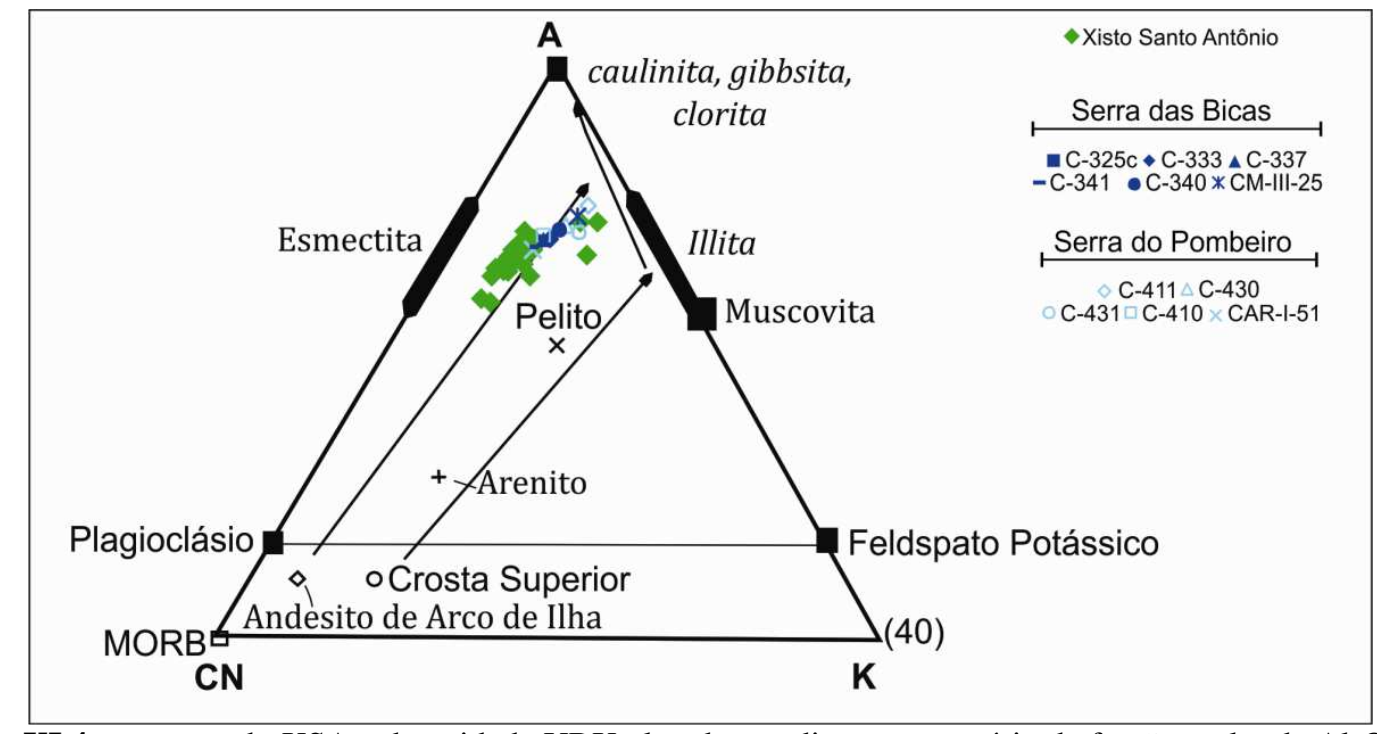

Figura XI.4: amostras do XSA e da unidade UBX plotadas no diagrama ternário da fração molar de $\mathrm{Al}_{2} \mathrm{O}_{3}$ (A) $\mathrm{CaO}+\mathrm{Na}_{2} \mathrm{O}$ em silicatos $(\mathrm{CN})-\mathrm{K}_{2} \mathrm{O}$ (K) extraído, modificado e traduzido de McLennan et al. (1990).

\section{XI.2. Geoquímica de elementos traços}

O diagrama spider (elaborado a partir dos dados apresentados na tabela XI.3), normalizado segundo a composição média da crosta superior de Taylor e McLennan (1995), apresentado na figura XI.5 mostra que as amostras do XSA são empobrecidas em Rb, Th, U, $\mathrm{Nb}$, Sr, Hf e Zr e enriquecidas em Cs, Ba e ETRP. Estas amostras se diferem da unidade UBX 
ao apresentar menores anomalias negativas de $\mathrm{Sr}$, empobrecimento em $\mathrm{Rb}$, $\mathrm{Th}$ e $\mathrm{Nb}$ e enriquecimento em Ba.

Os elementos alcalinos e alcalinos terrosos são solubilizados durante intemperismo, com exceção de $\mathrm{Rb}$, Cs e Ba que apresentam maior raio iônico e são retidos em argilominerais durante o intemperismo (Taylor e McLennan, 1985). Diagramas de $\mathrm{Al}_{2} \mathrm{O}_{3}$ vs. $\mathrm{Rb}$, Cs e $\mathrm{Ba}$ (figura XI.6) mostram uma fraca correlação positiva entre estes elementos traço e o óxido de alumínio (ao contrário das amostras UBX). O empobrecimento em Rb e Cs sugere um caráter menos pelítico.

\section{XI.2.1. Elementos Terras Raras (ETR)}

Os ETR do XSA (tabela XI.3) apresentam, assim como as rochas da unidade UBX, padrões de ETR típicos de rochas sedimentares pós-arqueanas (McLennan et al., 1990) com enriquecimento de ETRL, padrões relativamente constantes de ETRP e anomalias negativas de Eu (figura XI.7), mas têm valores totais de ETR maiores do que os PAAS e NASC.

Apresentam assinatura de ETR compatível aos valores intermediários do grupo (ii) da unidade UBX (tabela XI.4), valores semelhantes de anomalia de Eu, compatíveis com valores médios da crosta continental superior (McLennan et al., 1990), valores menores de fracionamento de ETRL e maiores valores de conteúdos totais de ETRP.

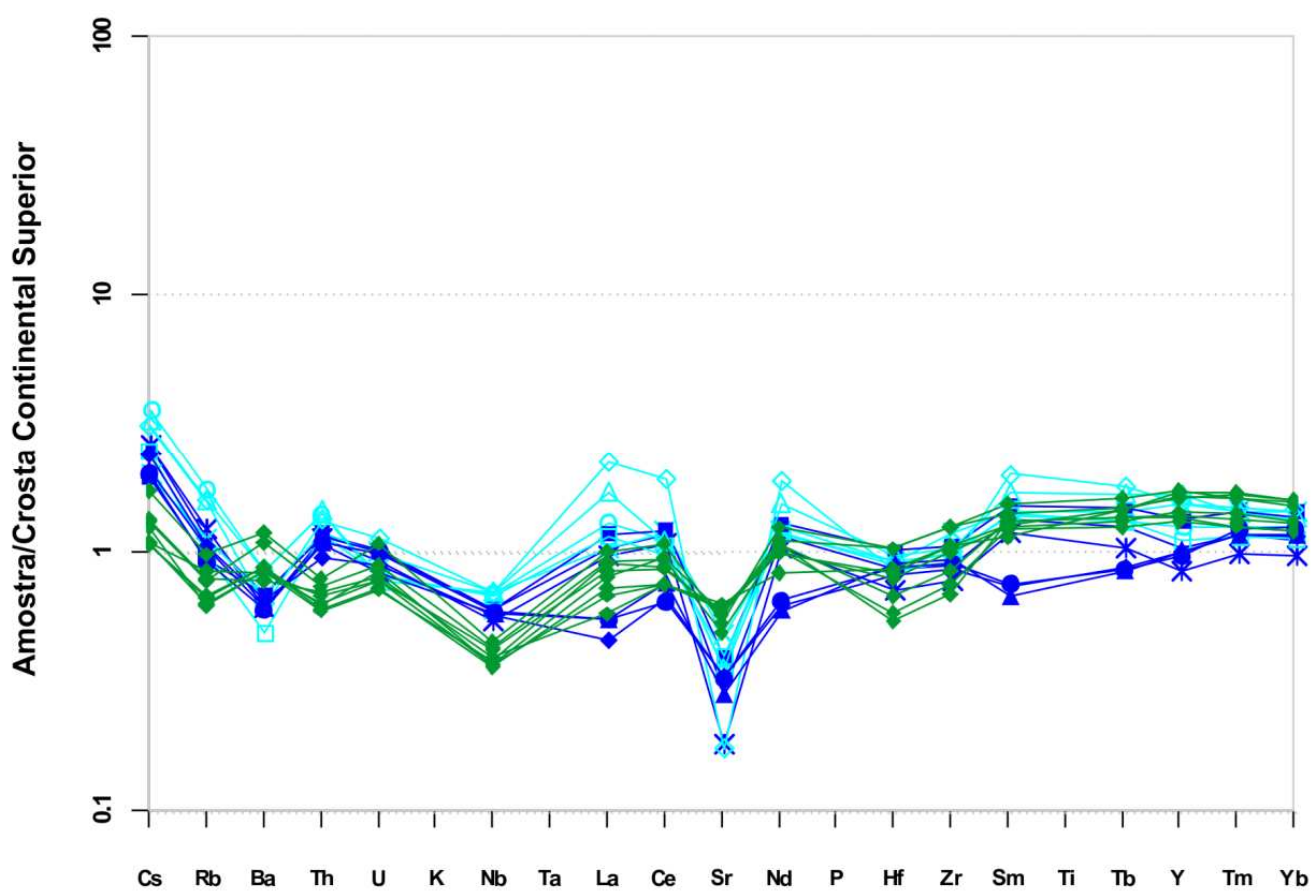

Figura XI.5: diagrama spider de elementos traços normalizados segundo valores para crosta continental superior de Taylor e McLennan (1995) para as amostras do XSA (em verde) e da unidade UBX (em azul). 


\begin{tabular}{|c|c|c|c|c|c|c|c|}
\hline & TG-18A & IBA-II-14 & $\begin{array}{c}\text { NESG } \\
\text { 1065B }\end{array}$ & $\begin{array}{c}\text { NESG } \\
833\end{array}$ & $\begin{array}{l}\text { NESG } \\
1067\end{array}$ & $\begin{array}{c}\text { NESG } \\
1116 A\end{array}$ & $\begin{array}{l}\text { NESG } \\
806 E\end{array}$ \\
\hline $\mathbf{R b}$ & 88,3 & 73,6 & 75,6 & 86,4 & 69,0 & 70,6 & 109 \\
\hline $\mathrm{Sr}$ & 218 & 210 & 203 & 170 & 198 & 201 & 184 \\
\hline $\mathbf{Y}$ & 37,2 & 31,3 & 35,4 & 30,4 & 29,9 & 28,6 & 38,2 \\
\hline $\mathbf{Z r}$ & 200 & 189 & 238 & 161 & 129 & 142 & 236 \\
\hline Nb & 9,69 & 8,95 & 9,15 & 10,5 & 9,41 & 10,4 & 11,2 \\
\hline Cs & 4,94 & 3,92 & 3,97 & 4,84 & 4,61 & 3,98 & 6,37 \\
\hline $\mathrm{Ba}$ & 424 & 475 & 481 & 593 & 461 & 464 & 650 \\
\hline La & 17,2 & 21,7 & 23,8 & 27,4 & 27,0 & 25,2 & 30,1 \\
\hline $\mathrm{Ce}$ & 47,8 & 47,6 & 60,6 & 59,4 & 55,6 & 55,0 & 68,7 \\
\hline Pr & 5,17 & 6,30 & 7,11 & 6,97 & 6,89 & 6,46 & 8,08 \\
\hline Nd & 21,5 & 25,7 & 28,8 & 27,8 & 27,8 & 26,1 & 32,1 \\
\hline Sm & 5,10 & 5,57 & 6,27 & 5,86 & 5,93 & 5,51 & 6,92 \\
\hline $\mathbf{E u}$ & 1,27 & 1,32 & 1,31 & 1,24 & 1,33 & 1,29 & 1,50 \\
\hline Gd & 5,25 & 5,25 & 5,97 & 5,28 & 5,44 & 5,02 & 6,33 \\
\hline Tb & 0,92 & 0,83 & 0,94 & 0,86 & 0,87 & 0,79 & 1,03 \\
\hline Dy & 5,61 & 4,85 & 5,52 & 4,96 & 4,96 & 4,59 & 5,94 \\
\hline Ho & 1,26 & 1,05 & 1,22 & 1,05 & 1,02 & 0,97 & 1,28 \\
\hline Er & 3,65 & 3,07 & 3,61 & 2,82 & 2,69 & 2,62 & 3,51 \\
\hline Tm & 0,56 & 0,47 & 0,55 & 0,44 & 0,41 & 0,41 & 0,53 \\
\hline $\mathbf{Y b}$ & 3,50 & 2,90 & 3,49 & 2,83 & 2,63 & 2,65 & 3,40 \\
\hline Lu & 0,57 & 0,47 & 0,57 & 0,44 & 0,40 & 0,40 & 0,52 \\
\hline Hf & 4,95 & 4,52 & 5,96 & 3,90 & 3,12 & 3,37 & 5,97 \\
\hline Ta & 0,75 & 0,64 & 0,72 & 0,73 & 0,67 & 0,90 & 0,74 \\
\hline $\mathbf{P b}$ & 19,8 & 14,2 & 14,3 & 15,9 & 13,4 & 14,4 & 19,1 \\
\hline Th & 7,50 & 6,37 & 6,64 & 7,79 & 6,33 & 6,73 & 8,46 \\
\hline $\mathbf{U}$ & 2,25 & 2,01 & 2,37 & 2,50 & 2,00 & 2,15 & 3,00 \\
\hline
\end{tabular}

Tabela XI.3: valores de elementos traço obtidos através de análise em LA-ICP MS para as amostras do XSA. Valores em ppm. 
Os valores de anomalia negativa de Eu, combinados com os valores de fracionamento de ETRP abaixo de 2,0 sugerem que rochas ígneas evoluídas, geradas a partir de diferenciação magmática intracrosta (McLennan et al., 1990), foram a principal fonte dos sedimentos do XSA, assim como da Unidade Biotita Xisto (figura XI.8). O empobrecimento em Sr observado na figura XI.5 sugere que o fracionamento químico intracrosta ocorreu principalmente pela cristalização fracionada de plagioclásio rico em $\mathrm{Ca}$, pois $\mathrm{Eu}^{2+}$ substitui $\mathrm{Sr}^{2+}$ neste mineral ocasionando as anomalias negativas de ambos elementos químicos no líquido residual (McLennan e Taylor, 1991).

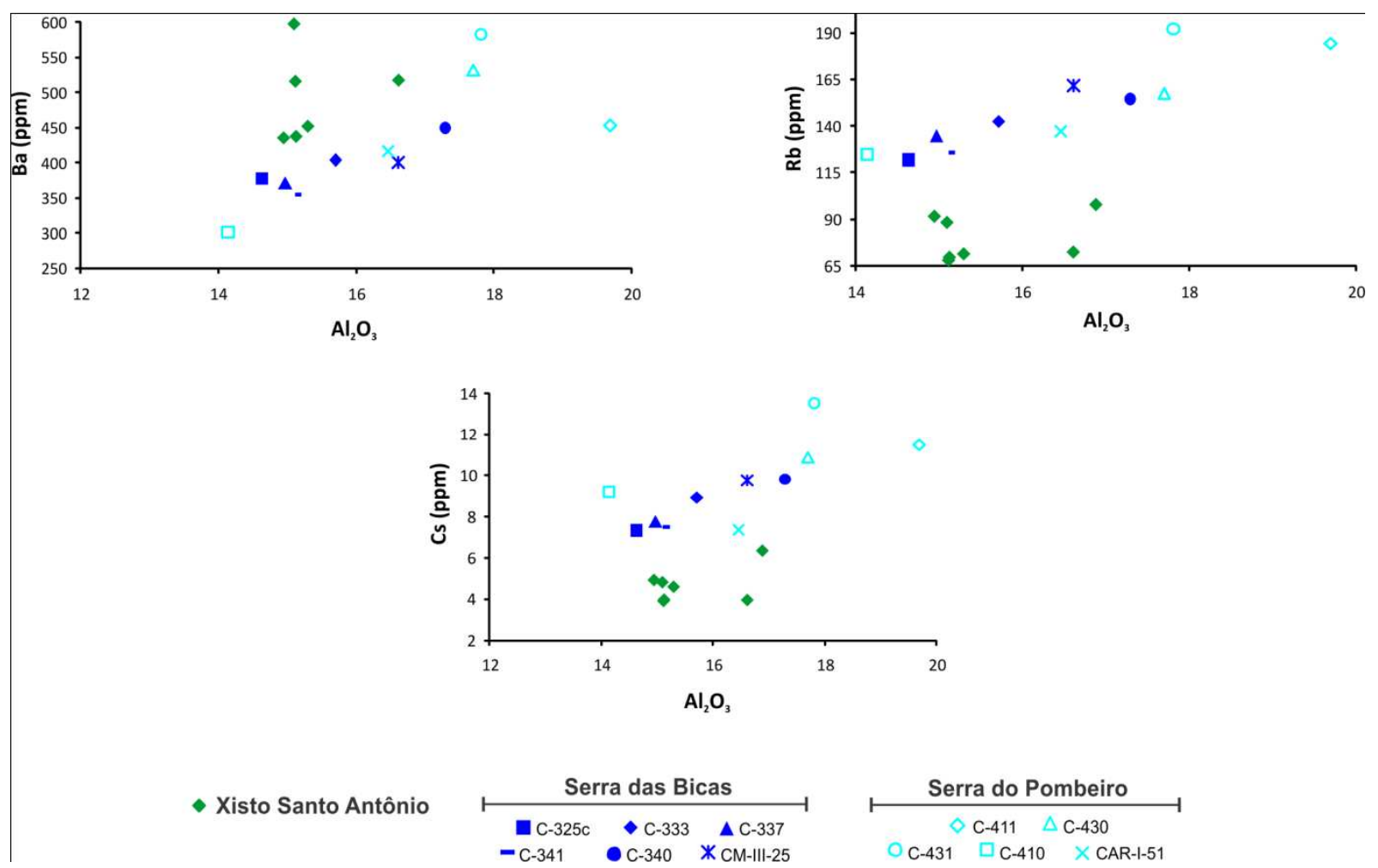

Figura XI.6: diagramas de $\mathrm{Al}_{2} \mathrm{O}_{3}$ vs. $\mathrm{Ba}$, $\mathrm{Rb}$ e Cs para as amostras do Xisto Santo Antônio e da unidade UBX.

Os valores totais e fracionamento de ETR, o fracionamento ETRP e a anomalia negativa de Eu são, todos, nas amostras XSA, menores que nas amostras UBX. Essas feições sugerem uma maior concentração em minerais pesados (zircão, apatita), plagioclásio e predominância de frações silto-arenosas em relação as amostras UBX. São também sugestivas de depósitos relativamente mais proximais à área-fonte. 


\begin{tabular}{|c|c|c|c|c|c|c|c|}
\hline & TG-18A & IBA-II-14 & $\begin{array}{l}\text { NESG } \\
\text { 1065B }\end{array}$ & $\begin{array}{c}\text { NESG } \\
833\end{array}$ & $\begin{array}{l}\text { NESG } \\
1067\end{array}$ & $\begin{array}{c}\text { NESG } \\
\text { 1116A }\end{array}$ & $\begin{array}{l}\text { NESG } \\
806 E\end{array}$ \\
\hline LaN & 46,97 & 59,21 & 64,83 & 74,54 & 73,62 & 68,61 & 82,05 \\
\hline CeN & 49,92 & 49,76 & 63,28 & 62,09 & 58,12 & 57,51 & 71,80 \\
\hline PrN & 37,71 & 45,98 & 51,89 & 50,84 & 50,26 & 47,19 & 59,01 \\
\hline $\mathbf{N d N}$ & 30,24 & 36,19 & 40,50 & 39,08 & 39,09 & 36,77 & 45,17 \\
\hline SmN & 22,10 & 24,11 & 27,16 & 25,36 & 25,68 & 23,86 & 29,95 \\
\hline EuN & 14,63 & 15,15 & 15,07 & 14,22 & 15,25 & 14,82 & 17,23 \\
\hline GdN & 17,17 & 17,14 & 19,52 & 17,27 & 17,77 & 16,39 & 20,69 \\
\hline TbN & 15,90 & 14,35 & 16,24 & 14,91 & 15,07 & 13,70 & 17,83 \\
\hline DyN & 14,74 & 12,72 & 14,49 & 13,02 & 13,01 & 12,04 & 15,60 \\
\hline HoN & 14,77 & 12,36 & 14,36 & 12,30 & 12,02 & 11,38 & 15,07 \\
\hline ErN & 14,66 & 12,34 & 14,50 & 11,33 & 10,79 & 10,53 & 14,11 \\
\hline TmN & 15,72 & 13,08 & 15,37 & 12,45 & 11,61 & 11,63 & 14,88 \\
\hline YbN & 14,12 & 11,68 & 14,08 & 11,42 & 10,60 & 10,68 & 13,70 \\
\hline LuN & 15,05 & 12,39 & 14,91 & 11,44 & 10,41 & 10,54 & 13,60 \\
\hline$\sum$ ETRL & 186,9 & 215,24 & 247,66 & 251,91 & 246,78 & 233,93 & 287,99 \\
\hline$\sum$ ETRP & 107,0 & 93,67 & 108,56 & 92,70 & 90,87 & 86,34 & 111,87 \\
\hline LaN/YbN & 3,33 & 5,07 & 4,60 & 6,53 & 6,95 & 6,43 & 5,99 \\
\hline LaN/SmN & 2,13 & 2,46 & 2,39 & 2,94 & 2,87 & 2,88 & 2,74 \\
\hline GdN/YbN & 1,22 & 1,47 & 1,39 & 1,51 & 1,68 & 1,54 & 1,51 \\
\hline EuN/Eu* & 0,75 & 0,75 & 0,65 & 0,68 & 0,71 & 0,75 & 0,69 \\
\hline
\end{tabular}

Tabela XI.4: valores de elementos terras raras (ETR) para as amostras do XSA. 


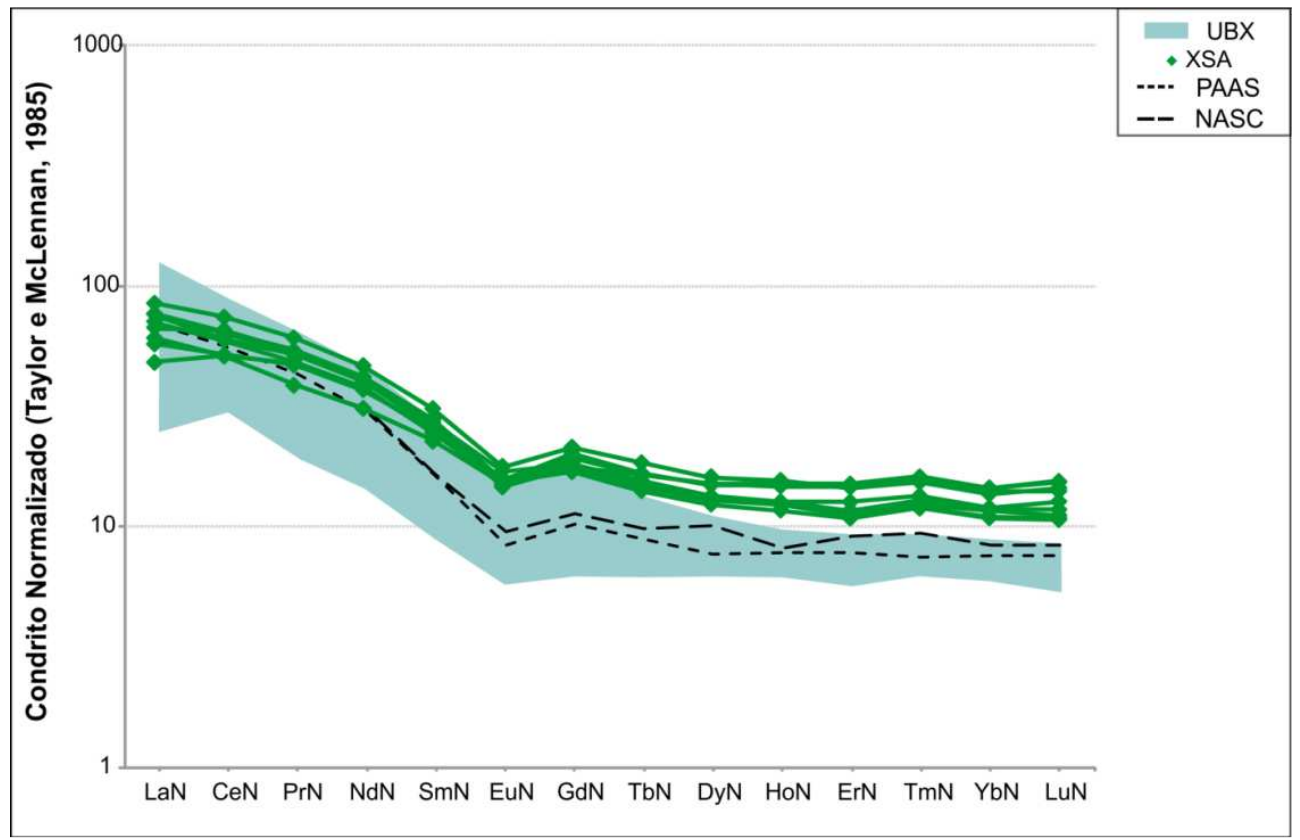

Figura XI.7: Diagrama com normalização condrito de Taylor \& McLennan (1985) mostrando o padrão de Elementos Terras Raras das amostras do XSA. Valores médios da UBX e de pelitos pós-Arqueanos (PAAS e NASC) foram plotados para comparação.

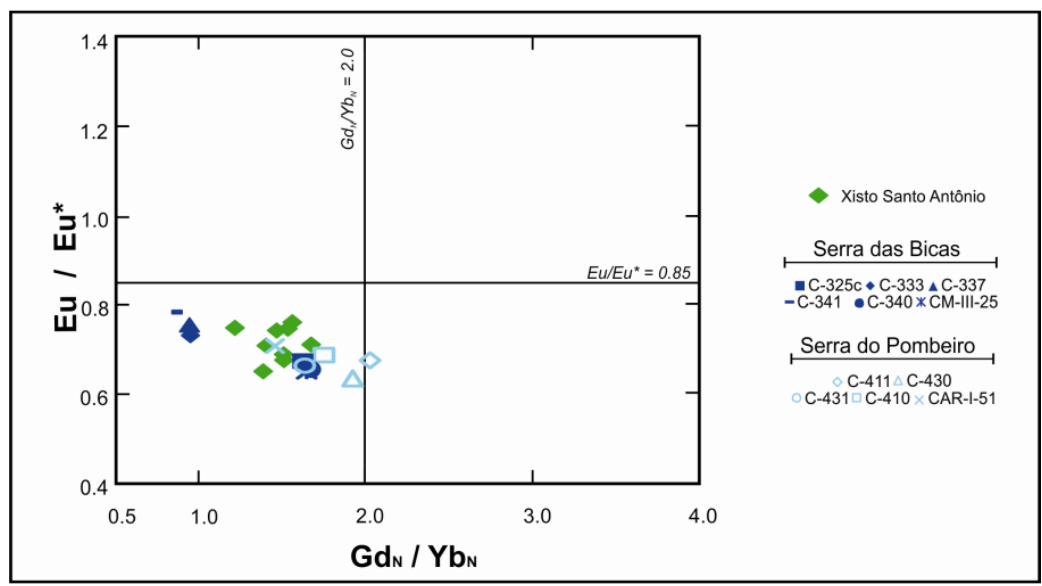

Figura XI.8: gráfico de fracionamento de ETRP vs. Anomalia de Eu com as amostras do XSA e da unidade UBX. Para linhas $\mathrm{Eu} / \mathrm{Eu}^{*}=0,85$ e $\mathrm{Gd}_{\mathrm{N}} / \mathrm{Yb}_{\mathrm{N}}=2,0$, ver capítulo VI.

\section{XI.2.2. Razão $T h / S c$}

Amostras do XSA, de maneira geral, apresentam valores da razão Th/Sc menores e maiores valores para razão $\mathrm{Cr} / \mathrm{V}$ (tabela XI.4 e figura XI.9). São relações químicas que sugerem a participação (ou preservação) de componentes máficos (McLennan et al., 1993). Como a concentração de minerais Fe-magnesianos, ricos em $\mathrm{Sc}$ e $\mathrm{Cr}$ pode estar mais 
preservada em presença de menor intemperismo químico, este, como visto no item XI.1.2, foi menor nas amostras XSA.

\begin{tabular}{cccc}
\hline & Th/Sc & Cr/V & Eu/Eu* \\
\hline UBX & $0,68-1,13$ & $0,66-0,91$ & $0,64-0,79$ \\
\hline XSA & $0,14-2,85$ & $0,68-1,04$ & $0,65-0,75$ \\
\hline
\end{tabular}

Tabela XI.5: valores da razão Th/Sc para as amostras do XSA e da unidade UBX.

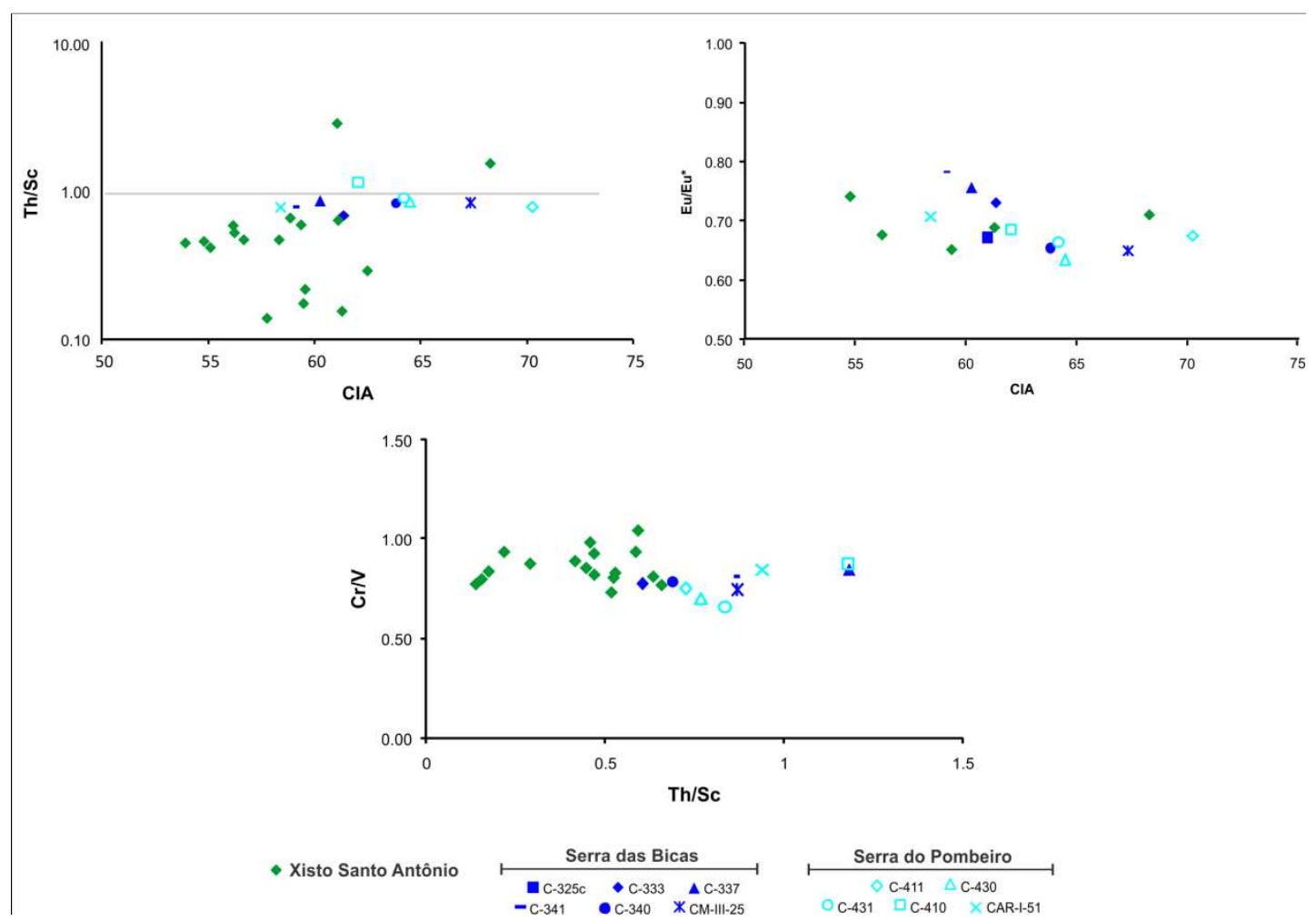

Figura XI.9: Diagramas CIA vs. Th/Sc, CIA vs. Eu/Eu* e Th/Sc vs. Cr/V para as amostras do XSA e da unidade UBX.

\section{XI.3. Sistema Rb-Sr em rocha total}

A tabela XI.5 e a figura XI.10 mostram as a variação de $\mathrm{Rb}(\mathrm{ppm}), \mathrm{Sr}$ (ppm), ${ }^{87} \mathrm{Rb} /{ }^{86} \mathrm{Sr},{ }^{87} \mathrm{Sr} /{ }^{86} \mathrm{Sr} \mathrm{e}{ }^{87} \mathrm{Sr} /{ }^{86} \mathrm{Sr}_{610}$ para as amostras do XSA e da unidade UBX. 


\begin{tabular}{|c|c|c|c|c|c|}
\hline & Rb (ppm) & Sr (ppm) & ${ }^{87} \mathrm{Sr} /{ }^{86} \mathrm{Sr}$ & ${ }^{87} \mathrm{Rb} /{ }^{86} \mathrm{Sr}$ & $\begin{array}{l}{ }^{87} \mathrm{Sr} /{ }^{86} \mathrm{Sr}_{\mathrm{i}} \\
(610 \mathrm{Ma})\end{array}$ \\
\hline UBX & $\begin{array}{c}121,80- \\
161,70\end{array}$ & $\begin{array}{l}67,70- \\
168,00\end{array}$ & $\begin{array}{c}0,73251- \\
0,77064\end{array}$ & $\begin{array}{c}2,20048- \\
6,43098\end{array}$ & $\begin{array}{c}0,71336- \\
0,71589\end{array}$ \\
\hline XSA & $\begin{array}{l}50,89- \\
133,38\end{array}$ & $\begin{array}{c}160,62- \\
223,61\end{array}$ & $\begin{array}{c}0,71361- \\
0,72635\end{array}$ & $\begin{array}{c}0,85308- \\
1,68968\end{array}$ & $\begin{array}{c}0,70612- \\
0,71165\end{array}$ \\
\hline
\end{tabular}

Tabela XI.6: dados isotópicos e elementais do sistema $\mathrm{Rb}-\mathrm{Sr}$ para as amostras do XSA e da unidade UBX. ${ }^{87} \mathrm{Rb} /{ }^{86} \mathrm{Sr}=\left(\mathrm{Rb}_{\mathrm{ppm}} / \mathrm{Sr} \mathrm{ppm}\right) * 2.8937 * 0,93047 ;{ }^{87} \mathrm{Sr} /{ }^{86} \mathrm{Sr}_{\mathrm{i}}={ }^{87} \mathrm{Sr} /{ }^{86} \mathrm{Sr}-{ }^{87} \mathrm{Rb} /{ }^{86} \mathrm{Sr}(\lambda \mathrm{t})$.

Os dados obtidos, nas amostras XSA, para a razão ${ }^{87} \mathrm{Sr} /{ }^{86} \mathrm{Sr}$ e para a razão ${ }^{87} \mathrm{Rb} /{ }^{86} \mathrm{Sr}$ são menores que aqueles para a unidade UBX. Indicam que as amostras XSA tiveram um menor período de residência na crosta. Indicam também uma maior contribuição de fontes máficas (juvenis) nos sedimentos.

\section{XI.4. Sm-Nd em rocha total}

Os valores da razões isotópicas, das idades modelo e $\varepsilon \mathrm{Nd}_{\mathrm{TDM}}$ e recalculados para 610 Ma são apresentados nas tabelas XI.7.

As amostras do XSA apresentam valores de $\varepsilon(0)$, idades modelo $\mathrm{T}_{\mathrm{DM}}$ e $\varepsilon \mathrm{Nd}_{610}$ menores quando comparados aos da unidade UBX (figura XI.10). Os valores de $\varepsilon \mathrm{Nd}_{610}$ indicam uma maior contribuição de material juvenil, compatível com as baixas razões ${ }^{87} \mathrm{Sr}^{86} \mathrm{Sr}_{610}$, As idades $\mathrm{T}_{\mathrm{DM}}$ são mais jovens, entre 1,16 e 1,39, provavelmente por uma menor variedade do material da área-fonte.

\begin{tabular}{|c|c|c|c|c|c|c|}
\hline & $\begin{array}{c}\text { Sm } \\
\text { (ppm) }\end{array}$ & $\begin{array}{c}\text { Nd } \\
\text { (ppm) }\end{array}$ & ${ }^{147} \mathrm{Sm} /{ }^{144} \mathrm{Nd}$ & ${ }^{143} \mathrm{Nd} /{ }^{144} \mathrm{Nd}$ & $\mathbf{T}_{\mathrm{DM}}(\mathrm{Ga})$ & $\varepsilon_{(610 M a)}$ \\
\hline UBX & $\begin{array}{l}3,685 \mathrm{a} \\
13,418\end{array}$ & $\begin{array}{c}18,901 \mathrm{a} \\
73,351\end{array}$ & $\begin{array}{c}0,1106 \mathrm{a} \\
0,1207\end{array}$ & $\begin{array}{c}0,5120 \mathrm{a} \\
0,5121\end{array}$ & $\begin{array}{c}1,550 \mathrm{a} \\
1,627\end{array}$ & $\begin{array}{c}-5,275 \mathrm{a}- \\
6,045\end{array}$ \\
\hline XSA & $\begin{array}{c}2,364 \mathrm{a} \\
4,408\end{array}$ & $\begin{array}{c}11,454 \mathrm{a} \\
20,868\end{array}$ & $\begin{array}{c}0,1235 \mathrm{a} \\
0,1358\end{array}$ & $\begin{array}{c}0,5123 \mathrm{a} \\
0,5124\end{array}$ & $\begin{array}{c}1,164 \mathrm{a} \\
1,399\end{array}$ & $\begin{array}{c}-1,794 \mathrm{a} \\
0,348\end{array}$ \\
\hline
\end{tabular}

Tabela XI.7: dados isotópicos e elementais do sistema Sm-Nd para as amostras do XSA e da unidade UBX.

Branco analítico para $\mathrm{Sm}=47$ pg e para $\mathrm{Nd}=114$; Razão isotópica ${ }^{147} \mathrm{Sm} /{ }^{144} \mathrm{Nd}$ calculada a partir da equação: $=\left[\left(\right.\right.$ Conc Sm/Conc Nd)*0,604491]; Razões isotópicas ${ }^{143} \mathrm{Nd} /{ }^{144} \mathrm{Nd}$ normalizadas para o valor de 0,7219

(DePaolo, 1981); Valor médio para a razão ${ }^{143} \mathrm{Nd} /{ }^{144} \mathrm{Nd}$ do padrão JNdi $=0,512100 \pm 0,000004$; Idade Modelo $\mathrm{T}_{\mathrm{DM}}$ calculada pela equação: $=\left\{\left[\left({ }^{143} \mathrm{Nd} /{ }^{144} \mathrm{Nd}\right)_{\mathrm{am}} / 0,512638\right]-1\right\}^{*} 10^{4}$, onde ${ }^{143} \mathrm{Nd} /{ }^{144} \mathrm{Nd}_{\mathrm{CHUR}}=0,512638$ (Hamilton et al., 1983); eNd(0) corresponde ao valor atual $(\mathrm{t}=0)$ e é calculado segundo a equação: = $\left\{\left[\left({ }^{143} \mathrm{Nd} /{ }^{144} \mathrm{Nd}\right)_{\mathrm{am}} / 0,512638\right]-1\right\} * 10^{4}$. 


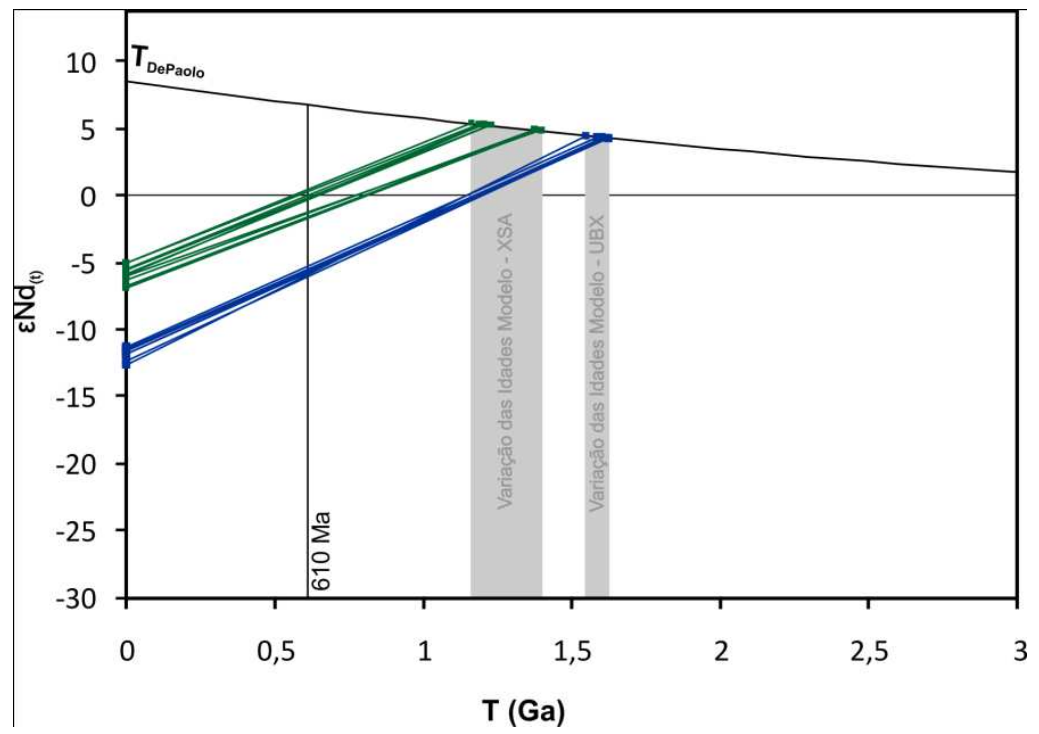

Figura XI.10:gráfico $\mathrm{T}(\mathrm{Ga}) v s . \mathrm{eNd}_{\mathrm{T}}$ para as amostras do XSA (em verde) e da unidade UBX (em azul).

\section{XI.5. Ambiente de deposição}

A figura XI.11 mostra gráficos elaborados por diversos autores para a classificação quanto ao ambiente tectônico de deposição de rochas sedimentares e segundo estes as amostras do XSA (com 3 exceções) são compatíveis quimicamente com sedimentos depositados em ambientes de colisão continental e margem ativa, possivelmente uma bacia relacionada a arcos magmáticos (figuras XI.11 C, D e F). Assim como as rochas da unidade UBX, os sedimentos precursores do XSA têm assinatura geoquímica que indica contribuição de crosta continental superior e de arco magmático em margem continental ativa. Apresentam uma maior afinidade com o ambiente de arco e mesmo de arco insular, por apresentarem valores de $\varepsilon_{\mathrm{Nd}}$ menos negativos a positivos (figura XI.11 C).

A diferença entre as duas unidades está, principalmente, na intensidade do intemperismo químico que as afetou. As amostras do XSA apresentam menores valores de CIA, menores razões $\mathrm{Th} / \mathrm{Sc}$ (abaixo de 1.0) (figuras XI.11 B e C) e maiores e altas razões La/Th (figura XI.11 F) o que sugere maior contribuição de rochas máficas e/ou menor intemperismo químico.

As razões isotópicas de $\mathrm{Sr}$ e $\mathrm{Nd}$ não são compatíveis com ambientes de margem passiva e com a erosão de crosta continental antiga (figuras XI.11 C, D e E). A assinatura geoquímica e isotópica indicam que a Unidade Biotita Xisto é equivalente distal do Xisto Santo Antônio. As figuras XI.11 B, C, D e F destacam a correlação entre essas unidades ao 
longo de um trend composicional que parte de composições juvenis e menos alteradas quimicamente.

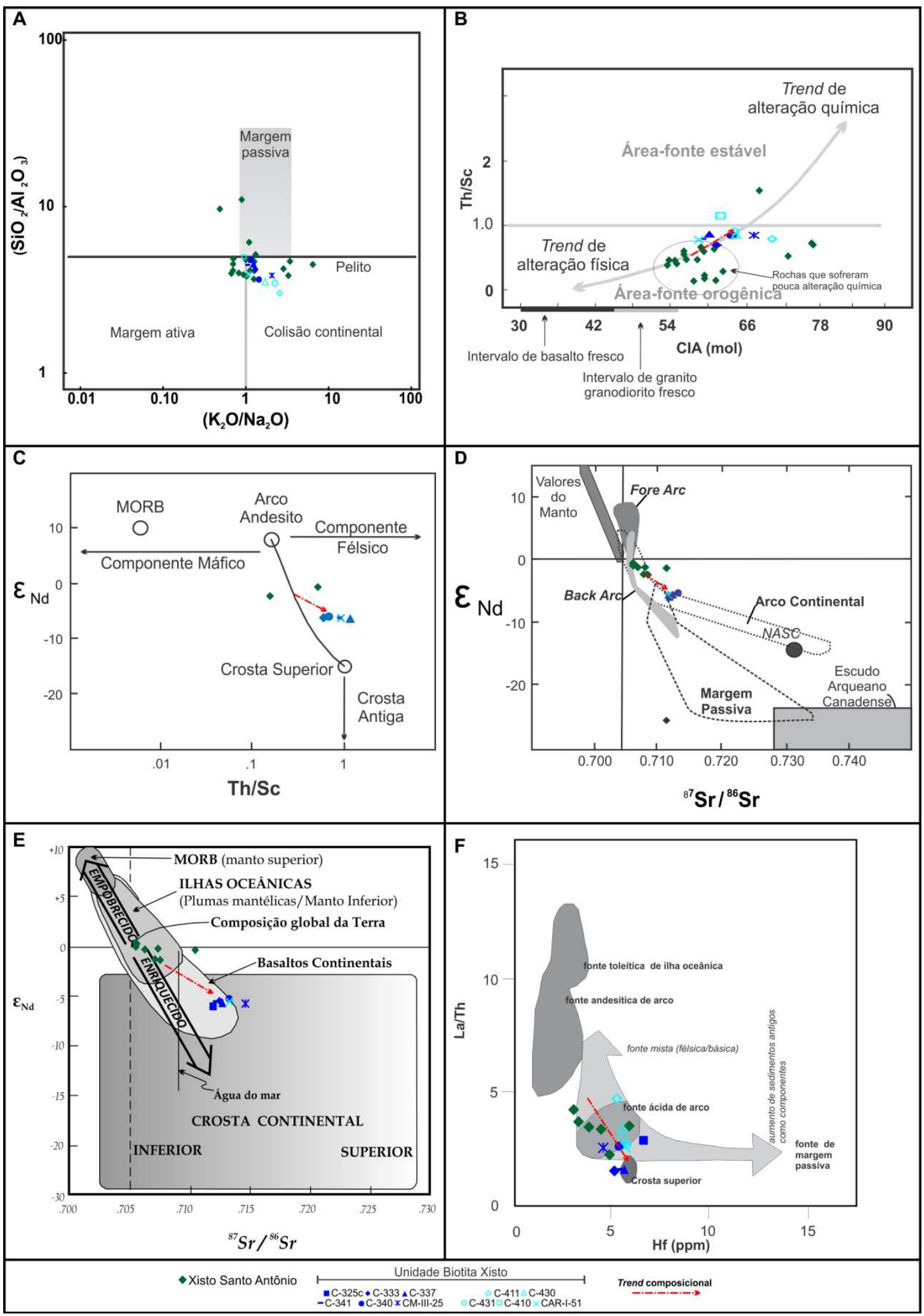

Figura XI.11: amostras do XSA e da unidade UBX plotadas em diagramas de classificação química segundo o ambiente tectônico de deposição. $\varepsilon N d$ e razões ${ }^{87} \mathrm{Sr} /{ }^{86} \mathrm{Sr}$ foram recalculados para $610 \mathrm{Ma}$. A e B: extraídos de Campos Neto et al. (2011); C e D: McLennan et al. (1990); E: White (2009); F: Floyd e Leveridge (1987). 


\section{CAPÍtUlo XII}

\section{CONCLUSÕES}

O estudo da proveniência e ambiente tectônico da UBX (UBX), e suas relações com a FC (FC) e o XSA (XSA), através de análises de geoquímica elemental, isotópica e do sistema $\mathrm{U}-\mathrm{Pb}$ em zircão detrítico permite as seguintes conclusões:

- Há uma clara afinidade geoquímica entre as unidades UBX e XSA, sendo que a última tem concentrações de elementos maiores semelhantes às amostras da UBX consideradas proximais. Por outro lado, as amostras da FC exibem padrões de correlação opostos para óxido de $\mathrm{K}^{+}$e menores concentrações de $\mathrm{SiO}_{2}, \mathrm{MgO}, \mathrm{CaO}, \mathrm{Na}_{2} \mathrm{O}$ e $\mathrm{P}_{2} \mathrm{O}_{5}$ e maiores de $\mathrm{TiO}_{2}, \mathrm{Fe}_{2} \mathrm{O}_{3}$ e $\mathrm{Al}_{2} \mathrm{O}_{3}$ do que as unidades mencionadas anteriormente;

* As análises das amostras da UBX sugerem intemperismo químico de intensidade e período de tempo moderados (no caso de exposição da área-fonte contemporânea a sedimentação) ou que a área fonte já estaria submetida a um intemperismo químico moderado. O XSA exibe padrão de intemperismo químico leve em um curto período de tempo, ou prevalência de intemperismo físico na área-fonte (Campos Neto et al., 2011). A FC, contrariamente às amostras da UBX e do XSA apresenta valores intermediários a altos de CIA, sugerindo uma intensa reciclagem e alteração do sedimento original (ciclos longos e/ou repetitivos de intemperismo químico) ou períodos de condições de clima úmido e quente extremas;

As unidades UBX e XSA apresentam padrões de ETR típicos de rochas sedimentares pós-arqueanas (McLennan et al., 1990), enquanto as amostras da FC apresentam forte fracionamento de ETR, de ETRP, ETRL e leve anomalia negativa de Eu. Os valores de anomalia negativa de Eu, combinados com os valores de fracionamento de ETRP sugerem que rochas ígneas evoluídas, geradas a partir de diferenciação magmática intracrosta (McLennan et al., 1990), foram a principal fonte dos sedimentos da UBX e do XSA. 
As razões $\mathrm{Th} / \mathrm{Sc}$ e $\mathrm{Cr} / \mathrm{V}$ indicam que as áreas-fonte dos sedimentos precursores das três unidades estudadas era formada predominantemente por rochas félsicas. O XSA, provavelmente devido ao menor intemperismo químico, possui maiores concentrações de minerais ferromagnesianos e, por isso, menores razões $\mathrm{Th} / \mathrm{Sc}$ e maiores razões $\mathrm{Cr} / \mathrm{V}$. Por outro lado, os valores das razões para a FC pode ter sido alterado devido ao forte intemperismo químico sofrido por estas rochas.

* Os dados obtidos, nas amostras XSA, para a razão ${ }^{87} \mathrm{Sr} /{ }^{86} \mathrm{Sr}$ e para a razão ${ }^{87} \mathrm{Rb} /{ }^{86} \mathrm{Sr}$ são menores que aqueles para a unidade UBX e indicam que as primeiras tiveram um menor período de residência na crosta e maior contribuição fontes juvenis nos sedimentos. Os valores obtidos para as amostras da FC indicam que estas tiveram um maior período de residência na crosta do que as amostras UBX.

* Os valores de $\mathrm{T}_{\mathrm{DM}}$ e $\varepsilon \mathrm{Nd}_{(\mathrm{t})}$ das unidades UBX e XSA indicam área-fonte composta por rochas de idades variadas e contribuição de assinatura juvenil, compatível com as baixas razões ${ }^{87} \mathrm{Sr} /{ }^{86} \mathrm{Sr}_{\mathrm{t}}$, sendo o XSA o que possui menor variedade na área-fonte e maior contribuição de rochas juvenis. Quando comparada com a FC, a UBX apresenta menores valores de $\mathrm{T}_{\mathrm{DM}}$ e $\varepsilon \mathrm{Nd}_{(\mathrm{t})}$ menos negativos, indicando que os sedimentos precursores da FC tiveram proveniência a partir de rochas fonte mais antigas e com assinatura isotópica mais evoluída.

As unidades UBX e XSA são compatíveis quimicamente com sedimentos depositados em ambientes de colisão continental, sendo a segunda compatível também com ambientes de margem ativa. A deposição ocorreu, possivelmente, em uma bacia relacionada a arcos magmáticos, com contribuição de crosta continental superior e de arco magmático em margem continental ativa, sem contribuição de crosta antiga, sendo que o XSA apresenta uma maior afinidade com o ambiente de arco (mesmo de arco insular) do que a unidade UBX.

* A FC apresenta proveniência de crosta continental superior com componente de crosta antiga associado ( $\varepsilon_{\mathrm{Nd}}$ fortemente negativo e altos valores para a razão ${ }^{87} \mathrm{Sr} /{ }^{86} \mathrm{Sr}$ ), diferenciando-a das outras unidades.

As razões isotópicas de $\mathrm{Sr}$ e $\mathrm{Nd}$ das três unidades não são compatíveis com ambientes de margem passiva. 
* A maioria dos cristais de zircão detrítico da UBX forneceu idades ${ }^{206} \mathrm{~Pb} /{ }^{207} \mathrm{~Pb}$ com distribuição essencialmente unimodal, no Neoproterozóico, fimCriogeniano e contribuição secundária no Paleoproterozóico, Riaciano. A classe modal ao redor de 665 Ma é comparável com a idade cristais de zircão detrítico do XSA, Nappe Andrelândia, e com a idade do magmatismo básico toleítico precursor das rochas retroeclogíticas da Nappe Liberdade (Campos Neto et al., 2011), e deve representar a época de maior atividade ígnea félsica na área-fonte de ambas as unidades.

* Valores de ${ }^{87} \mathrm{Sr}^{86}{ }^{86} \mathrm{Sr}_{625 \mathrm{Ma}}, \varepsilon_{\mathrm{Nd}} \mathrm{N}_{625 \mathrm{Ma}}$ e $\mathrm{Th} / \mathrm{Sc}$ mostram que as amostras da unidade UBX plotam no campo dos granulitos cálcio-alcalinos da Nappe Socorro-Guaxupé, o que corrobora a hipótese de que estas rochas, ou rochas vulcânicas co-genéticas, possam ter sido a fonte para os sedimentos da bacia. Granitos crustais sin-colisionais presentes na nappe forneceram os cristais detríticos ao redor de $635 \mathrm{Ma}$.

* Portanto, a deposição dos sedimentos precursores das unidades UBX e XSA se deu entre 630 Ma 611 Ma (idade do zircão detrítico mais jovem e do metamorfismo da Nappe Andrelândia, respectivamente) com área-fonte principal no arco magmático representado pela Nappe Socorro-Guaxupé.

* A pouca representatividade de idades no Paleoproterozóico e a ausência de assinaturas químicas de margem passiva, inviabilizam a possibilidade de o Cráton do São Francisco ser uma das áreas-fonte.

* Portanto, a UBX não é autóctone em relação ao Cráton do São Francisco, sendo, provavelmente, a unidade que compõe a frente da Nappe Andrelândia.

* Os zircões detríticos do Estateriano, do Riaciano, Neoarqueano e do Mesoarqueano encontrados na FC, podem ser relacionados ao sul do Cráton do São Francisco, respectivamente, ao vulcanismo e plutonismo do Rift Espinhaço, do Cinturão Mineiro, do Super Grupo Rio das Velhas e domos granitóides associados e nos Migmatitos Campo Belo.

* As idades no Mesoproterozóico, compatíveis com a orogênica grenviliana, estão ausentes neste cráton. Podem estar parcialmente representadas nas faixas marginais do Cráton de Angola e nas faixas orogênicas do Cráton Amazônico. 
As idades de zircão detrítico no Toniano podem ser oriundas em parte do arco insular Mara Rosa e em parte do Arco Magmático de Goiás, na borda da Microplaca Paranapanema.

* Se diferentes massas cratônicas possam ter sido área fonte para os depósitos da FC, a paleogeografia mais provável, possivelmente para todo o Grupo Carrancas, é a de um ambiente de rifte, antecessor à deriva e ao estabelecimento de uma margem continental passiva.

* A abrangência das idades dos grãos detríticos de zircão da FC (tanto no Arqueano e Paleoproterozóico, quanto no Mesoproterozóico) e das formações Chapada dos Pilões e Paracatu (Pimentel et al., 2011) permite a correlação, no Orógeno Brasília, entre os Grupos Carrancas e Canastra. 


\section{REFERÊNCIAS BIBLIOGRÁFICAS}

AHRENS, L. H. The convergent lead ages of the oldest monazites and uraninites (Rhodesia, Manitoba, Madagascar, and Transvaal). Geochimica et Cosmochimica Acta, v.7, n. 5-6, 294$300,1955$.

ÁVILA, C. A.; VALENÇA, J. G.; TEIXEIRA, W.; BARRUETO, H. R.; CORDANI, U. G.; MOURA, C. A. V.; PEREIRA, R. M.; MARTINS, V. T. Geocronologia U-Pb da Suite Serrinha: implicações para a evolução paleoproterozóica da margem sul do Cráton São Francisco. In: SIMPÓSIO DE VULCANISMO E AMBIENTES ASSOCIADOS, 3, 2005, Cabo Frio. Anais... Cabo Frio: 2005, p. 357 - 361.

ÁVILA, C. A.; TEIXEIRA, W.; CORDANI, U. G.; MOURA, C. A. V.; PEREIRA, R. M. Rhyacian (2.23-2.20 Ga) juvenile accretion in the southern São Francisco craton, Brazil: Geochemical and isotopic evidence from the Serrinha magmatic suite, Mineiro belt. Journal of South American Earth Sciences, v. 29, n. 2, p. 464 - 482, 2010,

BARROS, C. E., NARDI, L. V. S., DILLENBURG, S. R. Geoquímica de minerais detríticos em estudos de proveniência: uma revisão. Revista Pesquisas em Geociências, v. 32, n. 1, p. 3-15, 2005.

BASEI, M. A. S.; SIGA Jr., O.; SATO, K.; SPROESSER, W. M. A metodologia Urânio-Chumbo na USP. Princípios metodológicos, aplicações e resultados obtidos. Anais da Academia Brasileira de Ciências, v. 67, p. 221-237, 1995.

BASEI, M. A. S.; FRIMMEL, H. E.; NUTMAN, A. P.; PRECIOZZI, F.; JACOB, J. A conection between the Neoproterozoic Dom Feliciano (Brazil/Uruguai) and Gariep (Namibia/South Africa) orogenic belts. Precambrian Research, v. 139, p. 139 - 221, 2005.

BASEI, M. A. S.; FRIMMEL, H. E.; NUTMAN, A. P.; PRECIOZZI, F. West Gondwana amalgamation based on detrial zircon ages from Neoproterozoic Ribeira and Dom Feliciano belts of South America and comparison with coeval sequences from SW Africa. Geological Society of London, Special Publications, v. 294, p. 239 - 256, 2008.

BELOUSOVA, E. A., GRIFFIN, W. L., O’REILLY, S. Y., FISHER, N. I. Igneous zircon: trace element composition as an indicator of source rock type. Contribution to Mineralogy and Petrology, v. 143, p. 602-622, 2002.

BHATIA, M. R. Rare Earth Element geochemistry of Australian Paleozoic graywackes and mudrocks: provenance and tectonic control. Sedimentary Geology, v. 45, p. 97 - 113, 1985. 
BHATIA, M. R.; CROOK, K. A. W. Trace elements characteristics of graywackes and tectonic setting discrimination of sedimentary basins. Contributions to Mineralogy and Petrology, n. 92, p. $181-193,1986$.

CAMPOS NETO, M. C. Orogenic systems from Southwestern Gondwana: an approach to BrasilianoPan African Cycle and orogenic collage in Southwestern Brazil. In: CORDANI, U. G., MILANI, E. J., THOMAZ FILHO, A., CAMPOS, D. A. (Eds.). Tectonic Evolution of South America. $1^{\text {st }}$ ed. Rio de Janeiro: 31 INTERNATIONAL GEOLOGICAL CONGRESS, 2000, p. 335-365.

CAMPOS NETO, M. C. \& CABY, R. Neoproterozoic high pressure metamorphism and tectonic constraint from the nappe system south of São Francisco Craton, southeast Brazil. Precambrian Research, v. 97, p. 3 - 26, 1999.

. Terrane accretion and upward extrusion of high-pressure granulites in the Neoproterozoic nappes of southeast Brazil: petrologic and structural constraints. Tectonics, v. 19, n. 4, p. 669 - 687, 2000,

CAMPOS NETO, M. C.; FIGUEIREDO, M. C. H.; JANASI, V. A.; BASEI, M. A. S.; FREYER, B. J. The São José do Rio Pardo mangeritic-granitic suíte, southeasthern Brazil. Geochimica Brasiliensis, v. 2, p. 185 - 189, 1988.

CAMPOS NETO, M. C.; BASEI, M. A. S.; VLACH, S. R. F.; CABY, R.; SZABÓ, G. A. J.; VASCONCELOS, P. Migração de orógenos e superposição de orogêneses: um esboço da colagem brasiliana no sul do Cráton do São Francisco, SE - Brasil. Revista do Instituto de Geociências - USP, São Paulo, v. 4, n. 1, p. 13 - 40, 2004.

CAMPOS NETO, M. C.; JANASI, V. A.; BASEI, M. A. S.; SIGA JR, O. Sistema de Nappes Andrelândia, setor oriental: litoestratigrafia e posição estratigráfica. Revista Brasileira de Geociências, v. 37, p. 47 - 60, 2007. Suplemento 4.

CAMPOS NETO, M. C.; CIOFFI, C. R.; MORAES, R.; MOTTA, R. G.; JUNIOR, O. S.; BASEI, M. A. S. Structural and metamorphic controlo $n$ the exhumation of high-P granulites: The Carvalhos Klippe example, from the oriental Andrelândia Nappe System, southern portion of the Brasília Orogen, Brazil. Precambrian Research, v. 180, n. 3-4, p. 125 - 142, 2010,

CAMPOS NETO, M. C.; BASEI, M. A. S.; JANASI, V. A.; MORAES, R. Orogen migration and tectonic setting of the Andrelândia Nappe system: an Ediacaran western Gondwana collage, south of São Francisco craton. Journal of South American Earth Sciences (2011), doi:10,1016/j.jsames.2011.02.006.

CORDANI, U. G.; TEIXEIRA, W. 2007. Proterozoic accretionary belts in the Amazonian Craton. In: HATCHER Jr., R. D.; CARLSON, M. P., MCBRIDE, J. H., CATALÁN, J. R. M. (Eds.). 4-D Framework of Continental Crust. $1^{\text {st }}$ ed. Colorado: The Geological Society of America, 2007, p. $297-320$, 
CORFU, F.; HANCHAR, J. M.; HOSKIN, P. W. O.; KINNY, P. Atlas of zircon textures. In: HANCHAR, J. M.; HOSKIN, P. W. O. (eds.). Zircon: Reviews in Mineralogy and Geochemistry. Washington: The Mineralogical Society of America, 2003. Cap. 16, p. 469500 ,

DAVIS, D. W. Optimum linear regression and error estimation applied to U-Pb data. Canadian Journal of Earth Sciences, v. 19, p. 2141-2149, 1982.

DAVIS, D. W.; GRAY, J.; CUMMING, G. L. Determination of the ${ }^{87} \mathrm{Rb}$ decay constant. Geochimica et Cosmochimica Acta, v. 41, p. 1745-1749, 1977.

DEPAOLO, D. J. A Neodymium and Strontium isotopic study of the Mesozoic calc-alkaline granitic batholits of the Sierra Nevada and Peninsular Ranges, California. Journal of Geophysical Research, v. 86, n. 10, p. 10470-10488, 1981.

DEPAOLO, D. J.; WASSERBURG, G. J. Nd isotopic variations and petrogenetic models. Geophysical Research Letters, v. 3, n.5, p. 249-252, 1976.

DICKIN, A. P. 1995a. The Rb-Sr method. In: Radiogenic Isotope Geology. $2^{\text {nd }}$ ed. New York: Cambridge University Press, 1995. Cap. 3, p. 42-69. 1995b. The Sm-Nd method. In: Radiogenic Isotope Geology. $2^{\text {nd }}$ ed. New York: Cambridge University Press, 1995. Cap. 4, p. 70-100, 1995c. The Sm-Nd method. In: Radiogenic Isotope Geology. $2^{\text {nd }}$ ed. New York: Cambridge University Press, 1995. Cap. 5, p. 101-135.

DUSSIN, I. A. E DUSSIN, T. M. Supergrupo Espinhaço: Modelo de evolução geodinâmica.Geonomos, v. 3, p. 19 - 26, 1995.

EBERT, H. Resumo dos resultados obtidos no ano de 1955 no sul de Minas Gerais. Relatório Anual do Diretor Rio de Janeiro, DF, DGM / DNPM, p. 69 - 81, 1956.

EBERT, H. The Manganese-bearing Lafaiete Formation as a guide-horizon in the Precambrian of Minas Gerais. Anais da Academia Brasileira de Ciências Rio de Janeiro, RJ, v. 35, p. 545 $559,1963$.

EBERT, H. D.; CHEMALE Jr., F.; BABINSKI, M.; ARTUR, A. C.; VAN SCHMUS, W. R. Tectonic setting and $\mathrm{U}-\mathrm{Pb}$ zircon dating of the plutonic Socorro Complex in the Transpressive Rio Paraíba do Sul Shear belt, SE Brazil. Tectonics, v. 15, n. 2, p. 688 - 699, 1996.

FEDO, C. M.; SIRCOMBE, K. N.; RAINBIRD, R. H. Detrial zircon analysis of the sedimentary record. In: HANCHAR, J. M.; HOSKIN, P. W. O. (eds.). Zircon - Reviews in Mineralogy \& Geochemistry. Mineralogical Society of America and Geochemical Society: 2003, v. 53, p. 277-303.

FETTER, A. H., HACKSPACKER, P. C., EBERT, H. D., DANTAS, E. L., COSTA, A. C. D. New $\mathrm{Sm} / \mathrm{Nd}$ and $\mathrm{U} / \mathrm{Pb}$ geochronological constraints on the Archean to Neoproterozoic evolution of the Amparo basement complex of the central Ribeira belt, south-eastern Brazil. In: SOUTH 
AMERICAN SYMPOSIUM ON ISOTOPE GEOLOGY, 3, 2001, Santiago. Extend Abstracts, CD-ROM.

FLOYD, P. A.; LEVERIDGE, B. E. Tectonic environment of the Devonian Gramscatho basin, south Cornwall: framework mode and geochemical evidence from turbiditic sandstones. Journal of the Geological Society, v. 144, p. 531 - 542, 1987.

FRALICK, P. W.; KRONBERG, B. I. Geochemical discrimination of elastic sedimentary rock sources. Sedimentary Geology, v. 113, p. 111-124, 1997.

FRIMMEL, H. E.; FÖLLING, P. G.; ERIKSSON, P. G. Neoproterozoic tectonic and climatic evolution recorded in the Gariep Belt, Namibia and South Africa. Basin Research, v. 14, p. $55-67,2002$.

GARCIA, M.G.M.; CAMPOS NETO, M.C. Contrasting metamorphic conditions in the Neoproterozoic collision-realted nappes, south of São Francisco Craton, SE Brazil. Journal of South American Earth Sciences, v. 15, n. 8, p. 853 - 870, 2003.

GARRELS, R. M.; MACKENZIE, F. T. Evolution of sedimentary rocks. New York: Norton, 1971, 397 p.

GOLDRICH, S. S.; MUDREY, M. G. Dilatancy model for discordant U-Pb zircon ages. In: TUGARINOV, A. I. (ed.). Contributions to Recent Geochemistry and Analytical Chemistry. Moscow: Nauka Publication Office, p. 415-418, 1972.

HACKSPACHER, P.C., FETTER, A.H., EBERT, H.D., JANASI, V.A., DANTAS, E.L., OLIVEIRA, M.A.F., BRAGA, I.F., NEGRI, F.D.A. Magmatismo há 660-640 Ma no Domínio Socorro: registros de convergência pré-colisional na aglutinação do Gondwana Ocidental. Geologia USP - Série Científica, v. 3, n. 1, p. 85 - 96, 2003.

HAMILTON, P. J.; O’NIONS, R. K.; BRIDGWATER, D.; NUTMAN, A. Sm-Nd studies of Archean metasediments and metavolcanics from West Greenland and their implications for the Earth's early history. Earth and Planetary Science Letters, v. 62, p. 263-272, 1983.

HASKIN, L. A.; WILDEMAN, T. R.; FREY, F. A.; COLLINS, K. A.; KEEDY, C. R.; HASKIN, M. A. Rare Earths in sediments. Journal of Geophysics Research B: Solid Earth, v. 71, n. 24, p. 6091-6105, 1966.

HAUGhTON, P. D. W., TODD, S. P., MORTON, A. C. Sedimentary provenance studies. In: A. C. Morton, S. P. Todd \& P. D. W. Haughton (eds.). Developments in Sedimentary Provenance Studies. The Geological Society of London: Geological Society Special Publication, 1991, v. 57, p. $1-11$.

HEILBRON, M. Evolução metamórfico-estrutural da área entre Itutinga e Madre de Deus de Minas, MG. 1984. 151f. Dissertação (Mestrado em Geociências) - Instituto de Geociências, Universidade Federal do Rio de Janeiro, Rio de Janeiro, 1984. 
HEILBRON, M. O metamorfismo da área de Itutinga - Madre de Deus - MG. In: SIMPÓSIO DE GEOLOGIA DE MINAS GERAIS, 3., 1985, Belo Horizonte. Anais... Belo Horizonte: SBG Núcleo Sudeste, 1985. p. 219-227.

HERRON, M. M. Geochemical Classification of Terrigenous Sands and Shales from Core or Log Data. Journal of Sedimentary Petrology, v. 58, p. 820 - 829, 1988.

HOSKIN, P. W. O.; BLACK, L.P. Metamorphic zircon formation by solid-state recrystallization of protolith igneous zircon. Journal of Metamorphic Geology, v. 18, p. 423 - 439, 2000,

JAFFEY, A. H.; FLYNN, K. F.; GLENDENIN, L. E.; BENTLEY, W. C.; ESSLING, A. M. Precision measurement of the half-lives ans specific activities of U235 and U238. Physical Review C, v. 4, p. 1889-1907, 1971.

JANASI, V. A. Petrogênese de granitos crustais da Nappe de Empurrão Socorro-Guaxupé (SPMG): uma contribuição da geoquímica elemental e isotópica. Tese de Livre Docência Instituto de Geociências, Universidade de São Paulo, São Paulo, 1999.

JANASI, V. A.; VLACH, S. R. F.; ULBRICH, H. H. G. J. Enriched-mantle contributions to the Itú granitoid belt, southeastern Brazil: evidence from K-rich diorites and syenites. Anais da Academia Brasileira de Ciências, v. 65, p. 107-118, 1993.

JANASI, V. A.; ALVES, A.; VLACH, S. R. F. Granitos peraluminosos da porção central da Faixa Ribeira, estado de São Paulo: sucessivos eventos de reciclagem da crosta continental no neoproterozóico. Geologia USP - Série Científica, v. 3, p. 12 - 24, 2003.

JANASI, V. A.; VLACH, S. R. F.; CAMPOS NETO, M. C.; ULBRICH, H. H. G. J. Associated Atype subalkaline and high-K calc-alcaline granites in the itu granite province, southeastern Brazil: petrological and tectonic significance. The Canadian Mineralogist, v. 47, p. 1505 1526, 2009.

KAUlfuSS, G. A. Geocronologia e Geoquimica dos Núcleos do Setuva , Betara e Tigre , Noroeste de Curitiba-PR. 1991. Dissertação (Mestrado em Geociências) - Instituto de Geociências, Universidade de São Paulo, São Paulo, 2001.

$\mathrm{KROGH}, \mathrm{T}$. E. Improved accuracy of U-Pb zircon dating by selection of more concordant fractions using a high gradient magnetic separation technique. Geochimica et Cosmochimica Acta, v. 46, p. 631-635, 1982a.

KROGH, T. E. Improved accuracy of U-Pb zircon ages by the creation of more concordant systems using the air abrasion technique. Geochimica et Cosmochimica Acta, v. 46, p. 637-649, 1982b.

LUGMAIR, G. W. Sm-Nd ages: a new dating method (abs.). Meteoritics, v. 9, p. 369, 1974.

LUGMAIR, G. W.; SCHEININ, N. B.; MARTI, K. Search for extinct ${ }^{146} \mathrm{Sm}$, I. The isotopic abundance of ${ }^{142 \mathrm{Nd}}$ in the Juvinas meteorite. Earth and Planetary Science Letters, v. 27, p. 9479-9484, 1975. 
MACHADO, N.; SCHRANK, A.; ABREU, F. R.; KNAUER, L. G.; ALMEIDA ABREU, P. Resultados preliminares da geocronologia U/Pb na Serra do Espinhaço Meridional. Sociedade Brasileira de Geologia - Núcleo Minas Gerais, boletim, v. 10, p. 171 - 174, 1989.

MANGE, M. A.; MAURER, H. F. W. Heavy Minerals in Colour. London: Chapman \& Hall, 1992, $147 \mathrm{p}$.

MARTINS, L.; VLACH, S. R. F.; JANASI, V. A. Reaction microtextures of monazite: Correlation between chemical and age domains in the Nazaré Paulista migmatite, SE Brazil. Chemical Geology, v. 261, p. $271-285,2009$.

MCCULLOCH, M. T.; WASSERBURG, G. J. Sm-Nd and Rb-Sr chronology of continental crust formation. Science, v. 200, n. 4345, p. 1003-1011, 1978.

MCLENNAN, S. M. Relationships between the trace element composition of sedimentary rocks and upper continental crust. Geochemistry, Geophysics, Geosystems $\left(\mathbf{G}^{3}\right)$, v. 2, 2001.

MCLENNAN, S. M.; TAYLOR, S. R. Sedimentary rocks and crustal evolution: tectonic setting and secular trend. The Journal of Geology, v. 99, n. 1, p. 1 - 21, 1991.

MCLENANN, S. M., TAYLOR, S. R., MCCULLOCH, M. T., MAYNARD, J. B. Geochemical and $\mathrm{Nd}-\mathrm{Sr}$ isotopic composition of deep-sea turbidities: crustal evolution and plate tectonic associations. Geochimica et Cosmochimica Acta, v. 54, p. 2015-2050, 1990,

MCLENANN, S. M.; HEMMING, S.; McDANIEL, D. K.; HANSON, G. N. Geocheical approaches to sedimentation, provenance, and tectonics. In: JOHNSSON, M. J.; BASU, A. (eds.). Processes controlling the Composition of Clastic Sediments. Colorado: Geological Society of America, Special Paper 284, 1993.

MCLENANN, S. M.; HEMMING, S. R.; TAYLOR, S. R.; ERIKSSON, K. A. Early Proterozoic crustal evolution: Geochemical and $\mathrm{Nd}-\mathrm{Pb}$ isotopic evidence from metassedimentary rocks, southwestern North America. Geochimica et Cosmochimica Acta, v. 59, n. 6, p. 1153-1177, 1995.

MINSTER, J. F.; BIRCK, J. L.; ALLÈGRE, C. J. Absolute age of formation of chondrites studied by the ${ }^{87} \mathrm{Rb}^{87} \mathrm{Sr}$ method. Nature, v. 300, p. 414-419, 1982.

MORI, P. E.; REEVES, S.; CORREIA, C. T.; HAUKKA, M. Development of a fused glass disc XRF facility and comparison with pressed powder pellet technique at Instituo de Geociências, São Paulo University. Revista Brasileira de Geociências, v. 29, n. 3, p. 441-446, 1999.

MORIMOTO, N.; FABRIES,; J.FERGUNSON, A. K.; GINZBURG, I. V.; ROSS, M.; SEIFERT, F. A.; ZUSMAN, J.; AOKI, K.; GOTTARDI, G. Nomenclature of pyroxenes. American Mineralogist, v. 73, p. 1123-1133, 1988.

MORTON, A. C. Stability of detrial heavy minerals in Terciary sandstones from the North Sea Basin. Clay Minerals, v. 19, p. 287-308, 1984. 
MORTON, A. C.; HALLSWORTH, C. R. Processes controlling the composition of heavy mineral assemblages in sandstones. Sedimentary Geology, v. 124, p. 3-29, 1999.

MOTTA, R. G. Evolução tectono-metamórfica do Domínio Serra da Natureza, Terreno Andrelândia, MG. 2009. 158f. Dissertação (Mestrado em Geociências) - Instituto de Geociências, Universidade de São Paulo, São Paulo, 2009.

NANCE, W. B.; TAYLOR, S. R. Rare earth element patterns and crustal evolution I: Australian postArchean sedimentary rocks. Geochimica et Cosmochimica Acta, v. 40, p. 1539-1551, 1976.

NESBITT, H. W.; YOUNG, G. M. Early Proterozoic climates and plate motions inferred from major elements chemistry of lutites. Nature, v. 299, p. 715 - 717, 1982.

NESBITT, H. W.; YOUNG, G. M. Prediction of some weathering trends of plutonic and volcanic rocks based on thermodynamic and kinetic considerations. Geochimica et Cosmochimica Acta, v. 48, p. 1523-1534, 1984.

NESBITT, H. W.; YOUNG, G. M. Formation and diagenesis of weathering profiles.The Journal of Geology, v. 97, p. 129-147, 1989.

NEUMMAN, W.; HUSTER, E. Discussion of the ${ }^{87} \mathrm{Rb}$ half-life determined by absolute counting. Earth and Planetary Science Letters, v. 33, p. 277-288, 1976.

NISBET, E. G.; PEARCE, J. A. Clinopyroxene compositions in mafic lavas from different tectonic settings. Contributions to Mineralogy and Petrology, v. 63, p. 149-160, 1977.

NOCE, C. M.; MACHADO, N.; TEIXEIRA, W. U-Pb geochronology of gneisses and granitoids in the Quadrilátero Ferrífero (southern São Francisco craton): age constraints for Archean and Paleoproterozoic magmatism and metamorphism. Revista Brasileira de Geociências, v. 28, n. 1, p. $95-102,1998$.

PACIULLO, F. V. P. Mapeamento geológico-estrutural da área de Minduri - MG. In: SIMPÓSIO DE GEOLOGIA DE MINAS GERAIS, 2., 1983, Belo Horizonte. Anais... Belo Horizonte: SBG Núcleo Sudeste, 1983. p. 440 - 448.

PACIULLO, F. V. P., RIBEIRO, A., ANDREIS, R. R. Reconstrução de uma bacia fragmentada: o caso do Ciclo Deposicional Andrelândia. In: SIMPÓSIO DO CRÁTON SÃO FRANCISCO, 2, 1993, Salvador. Anais... Salvador: 1993, p. 224 - 226.

PACIULLO, F. V. P., RIBEIRO, A., ANDREIS, R. R., TROUW, R. A. J. The Andrelândia basin, a neoproterozoic intraplate continental margin, southern Brasília Belt, Brazil. Revista Brasileira de Geociências, v. 30, n. 1, p. 200 - 202, 2000,

PACIULlO, F. V. P., TROUW, R. A. J., RIBEIRO, A. Geologia da Folha Andrelândia. In: A. C. PEDROSA-SOARES, C. M. NOCE, R. A. J. TROUW, M. HEILBRON (orgs.), Projeto sul de Minas - Etapa 1. COMIG, UFRJ e UFMG, 2002. Cap. 4, p. 98 - 119. 
PETERNEL, R., TROUW, R. A. J., SCHMITT, R. Interferência entre duas faixas móveis neoproterozóicas: o caso das faixas Brasilia e Ribeira, no sudeste do Brasil. Revista Brasileira de Geociências, v. 35, n. 3, p. 297 - 310, 2005.

PETTIJOHN, F. J. Sedimentary rocks. New York: Harper and Row, 1975, 628p.

PETTIJOHn, F. J.; POTTER, P. E.; SIECER, R. Sand and Sandstone. New York, Heidelberg, Berlin: Springer-Verlag, 1972, 618p.

PIMENTEL, M. M.; RODRIGUES, J. B.; DEllagiUSTINA, M. E. S.; JUNGES, S. L. J.; MATTEINI, M. The tectonic evolution of the Neoproterozoic Brasília belt, central Brazil, based on SHRIMP and LA-ICPMS U-PB sedimentary provenance data: a review. Journal of South American Earth Sciences (2011). doi: 10,1016/j.jsames.2011.02.011.

PINSON, W. H.; SCHNETZLER, C. C.; BEISER, E.; FAIRBAIRN, H. W.; HURLEY, P. M. Rb-Sr age of stony meteorites. MIT Geochronological Laboratorie $11^{\text {th }}$ Ann. Rep, NYO-10, p. 517, 1963.

PIRES, F. R. M. Geologia do Distrito Manganesífero de Conselheiro Lafaiete. Dissertação (Mestrado) - Universidade Federal do Rio de Janeiro, Rio de Janeiro, 1978.

PRAZERES FILHO, H. J. Caracterização geológica e petrogenética do batólito granítico Três Córregos (PR-SP): Geoquímica isotópica (Nd-Sr-Pb), idades (ID-TIMS/SHRIMP) e $\delta 18$ O em zircão. 2005, 207f. Tese (Doutorado em Geociências) - Instituto de Geociências, Universidade de São Paulo, São Paulo, 2005.

PUPIN, J. P. Granite genesis related to geodynamics from Hf-Y in zircon. Transactions of the Royal Society of Edinburgh, v. 91, p. 245-256, 2000,

QUÉMÉNEUR, J. J. G.; RIBEIRO, A.; TROUW, R. A. J.; PACIULlO, F. V. P.; HEILBRON, M. Geologia da Folha de Lavras. Projeto sul de Minas - Etapa I: COMIG-UFMG-UFRJ-UERJ, 2002 .

RAINBIRD, R. H. et al. U-Pb geochronology of Riphean sandstone and gabbro from southeast Siberia and its bearing on the Laurentia-Siberia connection. Earth and Planetary Science Letters, v. 164 , p. 409-420, 1998.

RIBEIRO, A. \& HEILBRON, M. Estratigrafia e metamorfismo dos Grupos Carrancas e Andrelândia, sul de Minas Gerais. In: CONGRESSO BRASILEIRO DE GEOLOGIA, 32, 1982, Salvador. Anais... Salvador: SBG, 1982, p. 177 - 186.

RIBEIRO, A.; TROW, R. A. J.; ANDREIS, R. R.; PACIULLO, F.V.P.; VALENÇA, J. G. Evolução das bacias proterozóicas e o termo-tectonismo brasiliano na margem sul do Cráton São Francisco. Revista Brasileira de Geociências, v. 25, p. 235-248, 1995.

RIBEIRO, A., PACIULLO, F. V. P., TROUW, R. A. J., VALENÇA, J. G. Síntese geológica regional do bloco ocidental (Campos das Vertentes e Sul de Minas). In: A. C. PEDROSA-SOARES, C. 
M. NOCE, R. A. J. TROUW, M. HEILBRON (orgs.), Projeto sul de Minas - Etapa I. COMIG, UFRJ e UFMG, 2002. cap. 3, p. 51 - 83.

RIBEIRO, L. M. A. L. Estudo geológico-geocronológico dos Terrenos granito-gnáissicos e sequências metavulcanossedimentares da região do Betara (PR). 2006. Dissertação (Mestrado em Geociências) - Instituto de Geociências, Universidade de São Paulo, São Paulo, 2006.

RUDNICK, R. L.; GAO, S. Composition of the Continental Crust. In: HOLLAND, H. D.; TUREKIAN, K. K. (eds.) Treatise on Geochemistry. Oxford: Elsevier-Pergamon, p. 1-64, 2003.

RUSSEL, R. D.; AHRENS, L. H. Additional regularities among discordant lead-uranium ages. Reviews of Geophysics and Space Physics, v. 10, p. 529-549, 1957.

SANTOS, L. P.; CAMPOS NETO, M. C.; GROHMANN, C. H. Metamorphic path constrained by metapelitic rocks from the inner Aiuruoca-Andrelândia Nappe, south of São Francisco craton, SE Brazil. Journal of South American Earth Sciences, p. 725 - 741, 2004.

SCHOBBENHAUS, C.; HOPPE, A.; BAUMANN, A.; LORK, A. Idade U/Pb do vulcanismo Rio dos Remédios Chapada Diamantina, Bahia. In: CONGRESSO BRASILEIRO DE GEOLOGIA, 38, 1994, Balneário Camboriú. Resumos Expandidos. Balneário Camboriú: SBG, v.2, 1994, p. $397-398$.

SIGA Jr., O.; CURY, L. F.; HARARA, O. M. M.; RIBEIRO, L. M. A. L.; BASEI, M. A. S.; PRAZERES FILHO, H. J.; SATO, K.; PASSARELLI, C. R. Evidências de regimes extensionais no Estateriano no leste paranaense, com base em estudos geocronológicos U-Pb (zircão). In: SIMPÓSIO NACIONAL DE ESTUDOS TECTÔNICOS, 10, 2005, Curitiba. Resumos Expandidos. Curitiba: v. 10, 2005, p. 353 - 356.

SIGA Jr, O.; CURY, L. F.; McREATH, I.; RIBEIRO, L. M. A. L.; SATO, K.; BASEI, M. A. S.; PASSARELLI, C. R. Geology and geochronology of the Betara region in south-southeastern Brazil: Evidence for possible Statherian (1.80-1.75 Ga) and Calymmian (1.50-1.45 Ga) extension events. Gondwana Research, v. 19, n. 1, p. 260 - 274, 2011.

SILVA, M. P. Modelamento metamórfico de rochas das fácies xisto verde e anfibolito com uso de pseudosseções: exemplo das rochas da Klippe Carrancas, sul de Minas Gerais. 2010, 147f. Dissertação (Mestrado em Geociências) - Instituto de Geociências, Universidade de São Paulo, São Paulo, 2010,

STACEY, J. S.; KRAMERS, J. D. Approximation of terrestrial lead isotope evolution by a two-stage model. Earth and Planetary Science Letters, v. 26, p. 207-221, 1975.

TASSINARI, C. C. G., NUTMAN, A. P. Archean and Proterozoic multiple tectono-thermal events recorded by gneisses in the Amparo region, São Paulo State, Brazil. In: SOUTH AMERICAN 
SYMPOSIUM ON ISOTOPE GEOLOGY, 3, 2001, Santiago. Extended Abstracts. Santiago: 2001 , p. $252-254$.

TAYLOR, S. R.; MCLENANN, S. M. The Continental Crust: Its composition an evolution. Oxford: Blackwell, 1985, 312p.

TAYLOR, S. R.; MCLENANN, S. M. The geochemical evolution of the continental crust. Reviews of Geophysics, v. 33, p. 241-265, 1995.

TEIXEIRA, A. W. Influência da pilha de nappes na trajetória metamórfica da Nappe Andrelândia, borda sul do cráton São Francisco. 2008. 42f. Monografia de Trabalho de Formatura (Bacharelado em Geologia) - Instituto de Geociências, Universidade de São Paulo, São Paulo, 2008.

TEIXEIRA, W.; SABATÉ, P.; BARBOSA, J.; NOCE, C. M.; CARNEIRO, M. A. 2000, Archean and Paleoproterozoic tectonic evolution of the São Francisco Craton, Brazil. In: CORDANI, U. G., MILANI, E. J., THOMAZ FILHO, A., CAMPOS, D. A. (Eds.). Tectonic Evolution of South America. $1^{\text {st }}$ ed. Rio de Janeiro: 31 INTERNATIONAL GEOLOGICAL CONGRESS, 2000, p. $101-137$.

TOMKINS, H. S.; POWELL, R.; ELLIS, D. J. The pressure dependence of zirconium-in-rutile thermometer. Journal of Metamorphic Geology, v. 25, p. 703-713, 2007.

TOPFNER, C. Brasiliano-granitoide in den Bundesstaaten São Paulo und Minas Gerais, Brasilieneiene Vergleichende studie. Münchner Geol. Hefte, A17, p. 258, 1996. proveniencia UBX

TROUW, R. A. J., RIBEIRO, A., PACIULlO, F. V. P. Evolução estrutural e metamórfica de uma área a SE de Lavras - Minas Gerais. In: CONGRESSO BRASILEIRO DE GEOLOGIA, 31, 1980, Balneário de Camboriú. Anais... Balneário Camboriú: SBG, 1980, p. 2773 - 2784.

TROUW, R. A. J., PACIULLO, F. V. P., CHRISPIM, S. J., DAYAN, H. Análise de deformação numa área a SE de Lavras Minas Gerais. In: CONGRESSO BRASILEIRO DE GEOLOGIA, 37. 1982. Salvador. Anais... Salvador: SBG, 1982, p. 187 - 198.

TROUW, R. A. J.; RIBEIRO, A.; PACIULLO, F. V. P. Geologia estrutural dos Grupos São João del Rei, Carrancas e Andrelândia, sul de Minas Gerais. Anais da Academia Brasileira de Ciências, v. 55, n. 1, p. 71 - 85, 1983.

TROUW, R. A. J.; RIBEIRO, A.; PACIULLO, F. V. P. Contribuição à geologia da Folha Barbacena 1:250,000, In: CONGRESSO BRASILEIRO DE GEOLOGIA, 34. 1986, Goiânia. Anais... Goiânia: SBG, 1986, p. 974 - 986.

TROUW, R. A. J. \& PANKHURST, R. J. Idades radiométricas ao sul do Cráton São Francisco: região da folha Barbacena, Minas Gerais. In: SIMPÓSIO SOBRE O CRÁTON SÃO FRANCISCO, 2. 1993, Salvador. Anais... Salvador: SBG, 1993, p. 260 - 262.

TROUW, R. A. J., PACIULLO, F. V. P., RIBEIRO, A. A Faixa Alto Rio Grande reinterpretada como zona de interferência entre a Faixa Brasília e a Faixa Ribeira. In: CONGRESSO 
BRASILEIRO DE GEOLOGIA, 38, Balneário Camboriú. Boletim de Resumos... Balneário Camboriú: SBG, 1994, p. 234 - 235.

TROUW, R. A. J., HeIlbron, M., RIBEIRO, A., PACIUllo, F. V. P., VAlERIANO, C. M., ALMEIDA, J. C. H., TUPINAMBÁ, M., ANDREIS, R. R. The Central Segmento $f$ the Ribeira Belt. In: CORDANI, U. G., MILANI, E. J., THOMAZ FILHO, A., CAMPOS, D. A. (Eds.). Tectonic Evolution of South America. $1^{\text {st }}$ ed. Rio de Janeiro: 31 INTERNATIONAL GEOLOGICAL CONGRESS, 2000a, p. 335-365.

TROUW, R. A., RIBEIRO, A., PACIULlO, F. V. P., HEILBRON, M. Interference between the neoproterozoic Brasília and Ribeira belts, with special emphasis on high pressure granulites. In: INTERNATIONAL GEOLOGICAL CONGRESS, 31, 2000, Rio de Janeiro. Field Trip Guide: 2000 b, $45 f$

VALERIANO, C. M., MACHADO, N., SIMONETTI, A., VALlADARES, C. S., SEER, H. J., SIMÕES, L. S. A. U-Pb geochronology of the southern Brasília Belt (SE-Brazil): sedimentary provenance, Neoproterozoic orogeny and assembly of West Gondwana. Precambrian Research, v. 130, p. 27 - 55, 2004.

VALLADARES, C. S.; MACHADO, N.; HEILBRON, M.; GAUTHIER, G. Ages of detrial zircon from siliciclastic sucessions south of the São Francisco craton, Brazil: implications for the evolution of Proterozoic basins. Gondwana Research, v. 7, n. 4, p. 913 - 921, 2004.

VALlADARES, C. S., MACHADO, N., HEILbRON, M., DUARTE, B. P., GAUTHIER, G. Sedimentary provenance in the central Ribeira Belt base don laser-ablation ICPMS ${ }^{207} \mathrm{~Pb} /{ }^{206} \mathrm{~Pb}$ zircon ages. Gondwana Research, v. 13, p. 516 - 526, 2008.

ZACK, T.; MORAES, R.; KRONZ, A. Temperature dependence of Zr in rutile: empirical calibration of a rutile thermometer. Contributions to Mineralogy and Petrology, v. 148, p. 471-488, 2004a.

ZACK, T.; VON EYNATTEN, H.; KRONZ, A. Rutile geochemistry and its potencial use in quantitative provenance studies. Sedimentary Geology, v. 171, p. 34-58, 2004 b.

WATSON, E.B.; WARK, D.A.; THOMAS, J.B. Crystallization thermometers for zircon and rutile. Contributions to Mineralogy and Petrology, v. 151, n. 4, p. 413-433, 2006.

WHITE, W. M. Radiogenic Isotope Geochemistry. Ithaca: Cornell University, 2009. Disponível em: www.geo.cornell.edu/geology/classes/Chapters/Chapter08.pdf. Acesso em: 20 Dec de 2010, 